\title{
NTP TECHNICAL REPORT ON THE TOXICITY STUDIES OF \\ 1020 LONg MultiWALled Carbon Nanotubes ADMINISTERED BY INHALATION TO SPRAGUE DAWLEY (HSD:Sprague DaWleY ${ }^{\circledR}$ SD ${ }^{\circledR}$ ) RatS AND B6C3Fl/N MICE
}

NTP TOX 94

NOVEMBER 2019 


\section{NTP Technical Report on the Toxicity Studies of 1020 Long Multiwalled Carbon Nanotubes Administered by Inhalation to Sprague Dawley (Hsd:Sprague Dawley ${ }^{\circledR} \mathrm{SD}^{\circledR}$ ) Rats and B6C3F1/N Mice}

Toxicity Report 94

November 2019

National Toxicology Program

Public Health Service

U.S. Department of Health and Human Services

ISSN: 2378-8992

Research Triangle Park, North Carolina, USA 


\section{Foreword}

The National Toxicology Program (NTP) is an interagency program within the Public Health Service (PHS) of the Department of Health and Human Services (HHS) and is headquartered at the National Institute of Environmental Health Sciences of the National Institutes of Health (NIEHS/NIH). Three agencies contribute resources to the program: NIEHS/NIH, the National Institute for Occupational Safety and Health of the Centers for Disease Control and Prevention (NIOSH/CDC), and the National Center for Toxicological Research of the Food and Drug Administration (NCTR/FDA). Established in 1978, NTP is charged with coordinating toxicological testing activities, strengthening the science base in toxicology, developing and validating improved testing methods, and providing information about potentially toxic substances to health regulatory and research agencies, scientific and medical communities, and the public.

The Toxicity Report series began in 1991. The studies described in the Toxicity Report series are designed and conducted to characterize and evaluate the toxicologic potential of selected substances in laboratory animals (usually two species, rats and mice). Substances selected for NTP toxicity studies are chosen primarily on the basis of human exposure, level of production, and chemical structure. The interpretive conclusions presented in the Toxicity Reports are based only on the results of these NTP studies. Extrapolation of these results to other species, including characterization of hazards and risks to humans, requires analyses beyond the intent of these reports. Selection per se is not an indicator of a substance's toxic potential.

NTP conducts its studies in compliance with its laboratory health and safety guidelines and FDA Good Laboratory Practice Regulations and must meet or exceed all applicable federal, state, and local health and safety regulations. Animal care and use are in accordance with the Public Health Service Policy on Humane Care and Use of Animals. Studies are subjected to retrospective quality assurance audits before being presented for public review.

NTP Toxicity Reports are indexed in the National Center for Biotechnology Information (NCBI) Bookshelf database and are available free of charge electronically on the NTP website (http://ntp.niehs.nih.gov). Additional information regarding this study may be requested through Central Data Management (CDM) atcdm@niehs.nih.gov. Toxicity data are available through NTP's Chemical Effects in Biological Systems (CEBS) database: https://www.niehs.nih.gov/research/resources/databases/cebs/index.cfm. 


\section{Table of Contents}

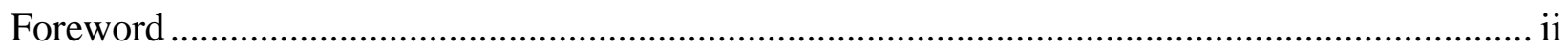

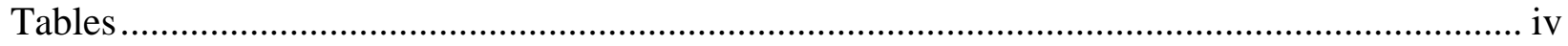

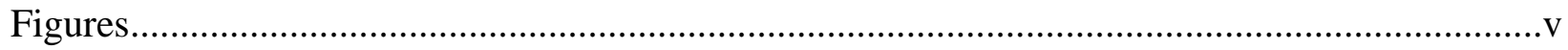

About This Report........................................................................................................ vi

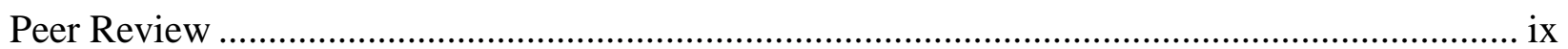

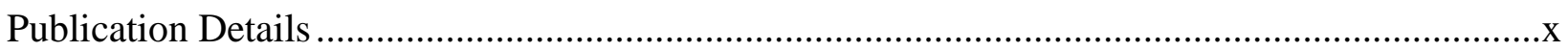

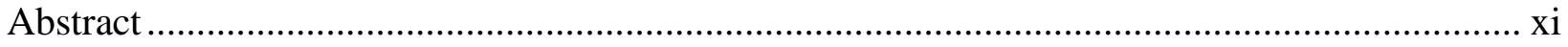

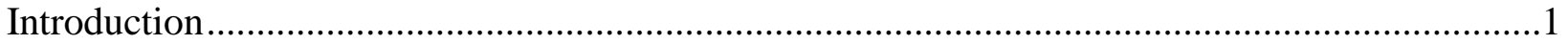

Chemical and Physical Properties ..................................................................................

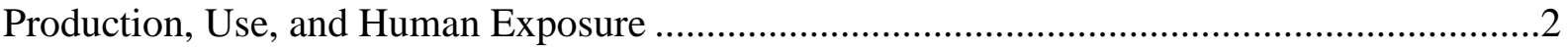

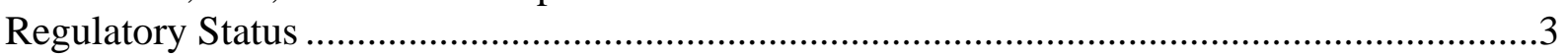

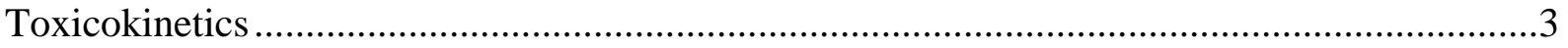

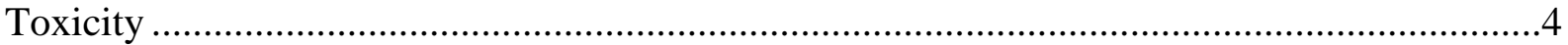

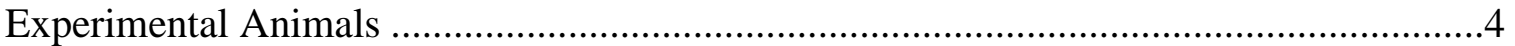

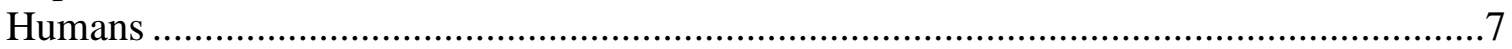

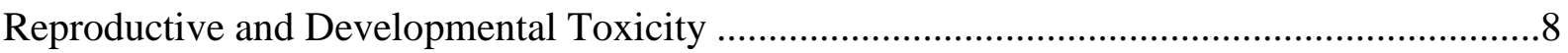

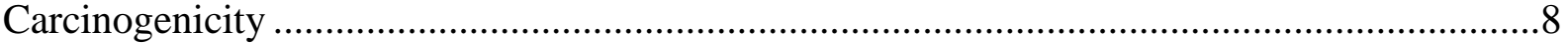

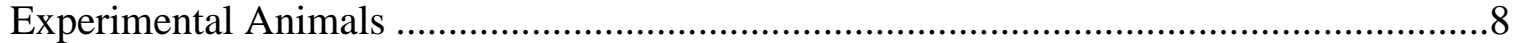

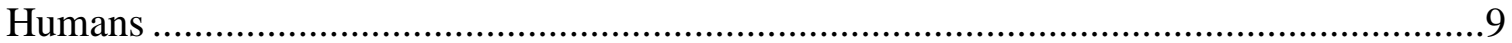

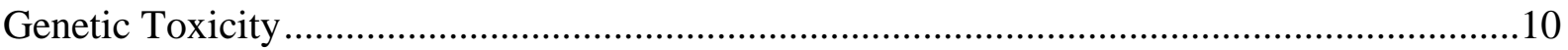

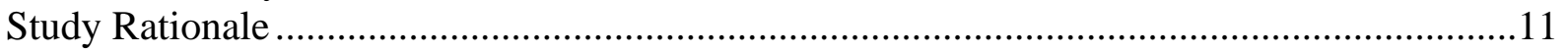

Materials and Methods.........................................................................................................13

Procurement and Characterization of 1020 Long Multiwalled Carbon Nanotubes ..................13

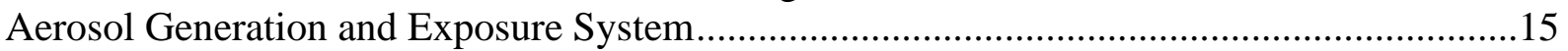

Aerosol Concentration Monitoring ......................................................................................16

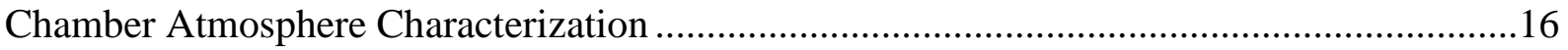

Animal Source .......................................................................................................

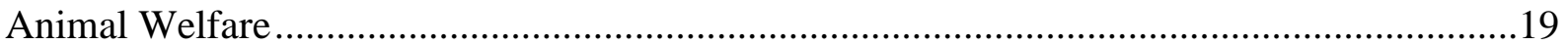

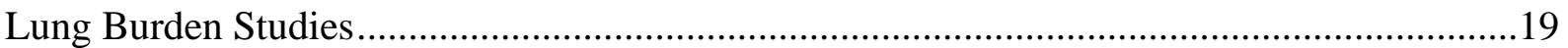

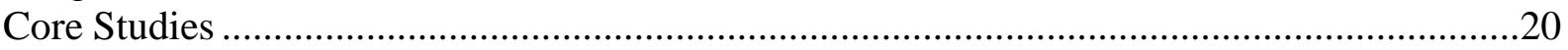

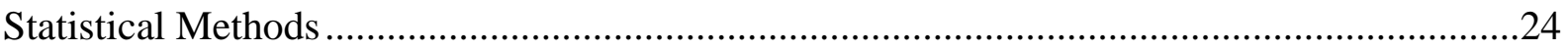

Calculation and Analysis of Lesion Incidences ............................................................24

Analysis of Continuous Variables .........................................................................24

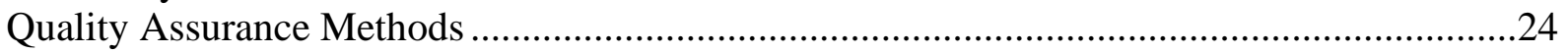

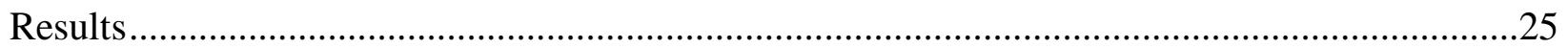

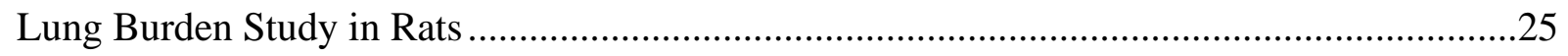

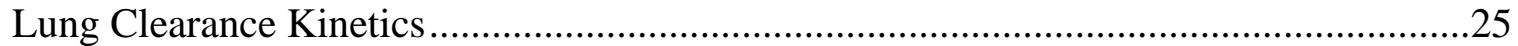

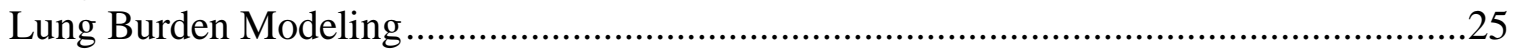

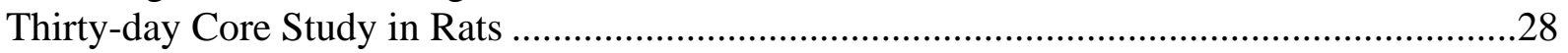

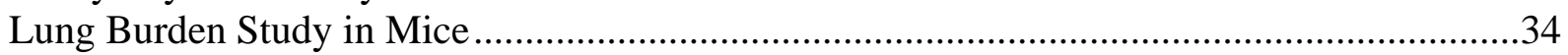




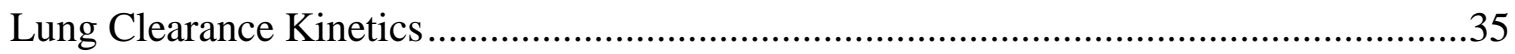

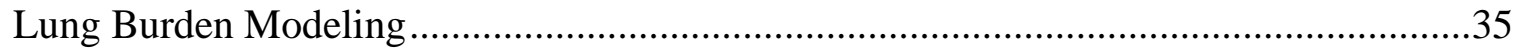

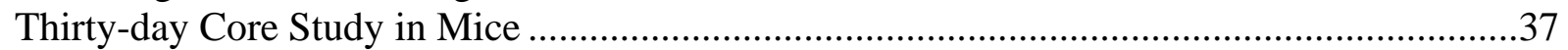

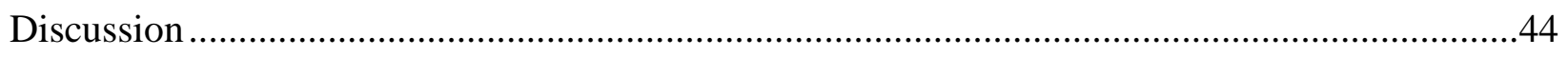

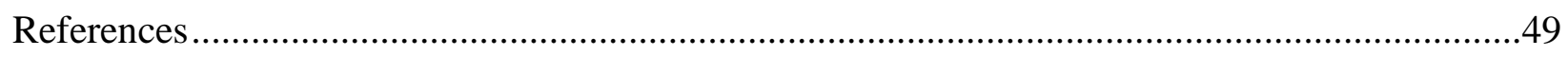

Appendix A. Summary of Nonneoplastic Lesions in Rats and Mice ...................................... A-1

Appendix B. Organ Weights and Organ-Weight-to-Body-Weight Ratios ......................................

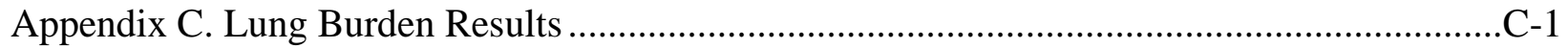

Appendix D. Chemical Characterization and Generation of Chamber Concentrations ............. D-1

Appendix E. Ingredients, Nutrient Composition, and Contaminant Levels in NTP-2000

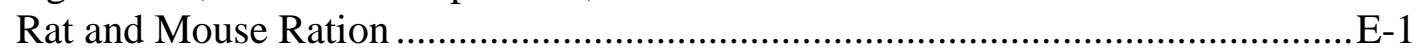

Appendix F. Sentinel Animal Program.................................................................................F-1

\section{Tables}

Summary of Findings Considered to Be Toxicologically Relevant in Rats and Mice

Exposed to 1020 Long Multiwalled Carbon Nanotubes by Inhalation for 30 Days xiii

Table 1. Experimental Design and Materials and Methods in the 30-day Inhalation Studies of 1020 Long Multiwalled Carbon Nanotubes

Table 2. Postexposure Lung Weights, Nickel Concentrations and Burdens, and 1020 Long Multiwalled Carbon Nanotube Burdens for Rats in the 30-day Inhalation Study of 1020 Long Multiwalled Carbon Nanotubes.

Table 3. Lung Deposition and Clearance Parameter Estimates for Rats in the 30-day Inhalation Study of 1020 Long Multiwalled Carbon Nanotubes

Table 4. Survival and Body Weights of Rats in the 30-day Inhalation Study of 1020 Long Multiwalled Carbon Nanotubes.

Table 5. Incidences of Nonneoplastic Lesions of the Respiratory System in Rats in the 30-day Inhalation Study of 1020 Long Multiwalled Carbon Nanotubes

Table 6. Incidences of Nonneoplastic Lesions of the Bronchial and Mediastinal Lymph Nodes in Rats in the 30-day Inhalation Study of 1020 Long Multiwalled Carbon Nanotubes

Table 7. Postexposure Lung Weights, Nickel Concentrations and Burdens, and 1020 Long Multiwalled Carbon Nanotube Burdens for Mice in the 30-day Inhalation Study of 1020 Long Multiwalled Carbon Nanotubes.

Table 8. Lung Deposition and Clearance Parameter Estimates for Mice in the 30-day Inhalation Study of 1020 Long Multiwalled Carbon Nanotubes

Table 9. Survival and Body Weights of Mice in the 30-day Inhalation Study of 1020 Long Multiwalled Carbon Nanotubes

Table 10. Incidences of Nonneoplastic Lesions of the Respiratory System in Mice in the 30-day Inhalation Study of 1020 Long Multiwalled Carbon Nanotubes

Table 11. Incidences of Nonneoplastic Lesions of the Bronchial and Mediastinal Lymph Nodes in Mice in the 30-day Inhalation Study of 1020 Long Multiwalled Carbon Nanotubes 


\section{Figures}

Figure 1. Multiwall Carbon Nanotube Structure ..........................................................................1

Figure 2. Electron Microscopy Images of 1020 Long Multiwalled Carbon Nanotubes ................14

Figure 3. Representative Transmission Electron Microscopy from 1020 Long Multiwalled Carbon Nanotubes Chamber Samples

Figure 4. Growth Curves for Rats Exposed to 1020 Long Multiwalled Carbon Nanotubes by Inhalation for 30 Days

Figure 5. Growth Curves for Mice Exposed to 1020 Long Multiwalled Carbon Nanotubes by Inhalation for 30 Days. 


\section{About This Report}

National Toxicology Program ${ }^{1}$

${ }^{1}$ Division of the National Toxicology Program, National Institute of Environmental Health

Sciences, Research Triangle Park, North Carolina, USA

\section{Collaborators}

D.L. Morgan, M.F. Cesta, J.A. Dill, G.L. Baker, H.N. Moore, C.R. Blystone, B. Collins, P.M. Foster, D. Germolec, B.K. Hayden, R.A. Herbert, M.J. Hooth, A.P. King-Herbert, G.E. Kissling, T.E. Lapainis, J. Lovaglio, D.E. Malarkey, K.R. Shockley, S.L. Smith-Roe, M.D. Stout, G.S. Travlos, M.K. Vallant, S. Waidyanatha, N.J. Walker, K.L. Witt

Division of the National Toxicology Program, National Institute of Environmental Health Sciences, Research Triangle Park, North Carolina, USA

Evaluated and interpreted results and reported findings

D.L. Morgan, Ph.D., Study Scientist

M.F. Cesta, D.V.M., Ph.D., Study Pathologist

C.R. Blystone, Ph.D.

B. Collins, M.S.

P.M. Foster, Ph.D.

D. Germolec, Ph.D.

R.A. Herbert, D.V.M., Ph.D.

M.J. Hooth, Ph.D.

A.P. King-Herbert, D.V.M.

G.E. Kissling, Ph.D.

D.E. Malarkey, D.V.M., Ph.D.

K.R. Shockley, Ph.D.

S.L. Smith-Roe, Ph.D.

M.D. Stout, Ph.D.

G.S. Travlos, D.V.M.

M.K. Vallant, B.S., M.T.

S. Waidyanatha, Ph.D.

N.J. Walker, Ph.D.

K.L. Witt, M.S.

Battelle Toxicology Northwest, Richland, Washington, USA

Conducted studies and evaluated pathology findings

J.A. Dill, Ph.D., Principal Investigator

G.L. Baker, Ph.D., Study Director

H.N. Moore, Ph.D., Study Director

B.K. Hayden

T.E. Lapainis, Ph.D.

J. Lovaglio, D.V.M. 


\section{Contributors}

Experimental Pathology Laboratories, Inc., Sterling, Virginia, USA

Provided pathology review

M.H. Hamlin, II, D.V.M., Principal Investigator

A.E. Brix, D.V.M., Ph.D.

M.M. Gruebbel, D.V.M., Ph.D.

R.A. Miller, D.V.M., Ph.D.

Dynamac Corporation, Research Triangle Park, North Carolina, USA

Prepared quality assessment audits

S. Brecher, Ph.D., Principal Investigator

S. Iyer, B.S.

V.S. Tharakan, D.V.M.

NTP Pathology Peer Review, National Institute of Environmental Health Sciences, Research Triangle Park, North Carolina, USA

Evaluated slides and contributed to pathology report on 30-day rats and mice

(October 24, 2012)

M.M. Gruebbel, D.V.M., Ph.D., Coordinator, Experimental Pathology Laboratories, Inc.

A.E. Brix, D.V.M., Ph.D., Experimental Pathology Laboratories, Inc.

M.F. Cesta, D.V.M., Ph.D., National Toxicology Program

G.P. Flake, M.D., National Toxicology Program

R.A. Herbert, D.V.M., Ph.D., National Toxicology Program

R.A. Miller, D.V.M., Ph.D., Experimental Pathology Laboratories, Inc.

Social \& Scientific Systems, Inc., Research Triangle Park, North Carolina, USA

Provided statistical analyses

M.V. Smith, Ph.D., Principal Investigator

L.J. Betz, M.S.

S.F. Harris, M.S.

J.D. Krause, Ph.D.

C.G. Leach, M.S.

Biotechnical Services, Inc., Little Rock, Arkansas, USA

Prepared report

S.R. Gunnels, M.A., Principal Investigator

K.K. Coker, Ph.D.

L.M. Harper, B.S.

E.S. Rathman, M.S.

Division of the National Toxicology Program, National Institute of Environmental Health Sciences, Research Triangle Park, North Carolina, USA

Provided oversight of external peer review

E.A. Maull, Ph.D.

M.S. Wolfe, Ph.D. 
ICF, Durham, North Carolina, USA

Provided contract oversight

D.F. Burch, M.E.M.

J. Wignall, M.S.P.H.

Conducted external peer review

S.E. Blaine, B.A.

L.M. Green, M.P.H.

B.C. Riley, B.S.

Prepared report

T.W. Cromer, M.P.S.

J.S. Frye, M.S.L.S.

T. Hamilton, M.S.

K.R. Helmick, M.P.H.

A.M. Ichida, Ph.D.

C.R. Lieb, B.S.

B.C. Riley, B.S. 


\section{Peer Review}

The draft NTP Technical Report on the Toxicity Studies of 1020 Long Multiwalled Carbon Nanotubes(L-MWNT-1020) Administered by Inhalation to Sprague Dawley (Hsd:Sprague Dawley $\left.{ }^{\circledR} S D^{\circledR}\right)$ Rats and B6C3F1/N Mice was evaluated by the reviewers listed below. These reviewers served as independent scientists, not as representatives of any institution, company, or governmental agency. In this capacity, reviewers determined if the design and conditions of these NTP studies were appropriate and ensured that this NTP Toxicity Report presented the experimental results and conclusions fully and clearly.

\section{Peer Reviewers}

Tara Sabo-Attwood, Ph.D.

Department of Environmental and Global Health

University of Florida

Gainesville, Florida, USA

Wanda Haschek-Hock, Ph.D.

Department of Pathobiology

University of Illinois

Urbana, Illinois, USA

Devon Andres, Ph.D.

Tauri Group

Bel Air, Maryland, USA 


\section{Publication Details}

Publisher: National Toxicology Program

Publishing Location: Research Triangle Park, NC

ISSN: 2378-8992

DOI: https://doi.org/10.22427/NTP-TOX-94

Report Series: NTP Toxicity Report Series

Report Series Number: 94

Official citation: National Toxicology Program (NTP). 2019. NTP technical report on the toxicity studies of 1020 long multiwalled carbon nanotubes (L-MWNT-1020) administered by inhalation to Sprague Dawley (Hsd:Sprague Dawley ${ }^{\circledR} \mathrm{SD}^{\circledR}$ ) rats and B6C3F1/N mice. Research Triangle Park, NC: National Toxicology Program. Toxicity Report 94. 


\section{Abstract}

Multiwalled carbon nanotubes (MWCNTs) are highly ordered hexagonal lattices of carbon atoms arranged into cylinders by hydrogen bonding, dipolar forces, hydrophilic or hydrophobic interactions, gravity, and other forces. MWCNTs are synthesized by applying energy to a carbon source, which produces individual or groups of carbon atoms that reassemble into tubes. One of the primary uses of MWCNTs is in nanotube-reinforced polymer composite materials that take advantage of their low-density and high load-bearing capacity. Nanoscale materials were nominated by the Rice University Center for Biological and Environmental Nanotechnology to the National Toxicology Program for toxicologic testing. Because long-term inhalation toxicity and carcinogenicity studies were being conducted on a relatively short, rigid MWCNT, a representative long and thin MWCNT was selected for these studies. Following an evaluation of 24 different long, thin MWCNTs, the 1020 Long Multiwalled Carbon Nanotube (L-MWNT1020) (Sun Innovations, Fremont, CA) was selected for study based on availability, high purity ( $97 \%)$, and the low amount of residual nickel catalyst ( $0.52 \%$ by weight). The average LMWNT-1020 nanotube length was 2,600 nm and the average width was $15.3 \mathrm{~nm}$. Because nickel was shown to be tightly bound to L-MWNT-1020, tissue nickel content was measured to determine lung burden.

The objective of these 30-day studies was to obtain lung burden, clearance, and toxicity data to be used in setting exposure concentrations for a chronic inhalation study of L-MWNT-1020. For lung burden studies, groups of 25 male and 25 female rats and mice were exposed to L-MWNT1020 by whole-body inhalation at concentrations of $0,0.1,0.3,1,3$, or $10 \mathrm{mg} / \mathrm{m}^{3}, 6$ hours plus T90 (12 minutes) per day, 5 days per week for 30 (males) or 31 (females) days, and necropsied on the last exposure day or after 14, 42, or 126 days of recovery. For the core studies, groups of 10 male and 10 female rats and mice were exposed to L-MWNT-1020 at the same concentrations as the lung burden studies for the same length of time and necropsied on the last exposure day.

L-MWNT-1020 lung burdens in rats and mice generally decreased with increasing postexposure time but were quite variable across the exposed groups. L-MWNT-1020 clearance rates were similar in 0.1 and $0.3 \mathrm{mg} / \mathrm{m}^{3}$ male and female rats with half-lives in the range of 52 to 64 days in male and female rats and 47 to 96 days in male and female mice. Clearance from the lung became progressively slower at exposure concentrations of $1 \mathrm{mg} / \mathrm{m}^{3}$ (rats) or $3 \mathrm{mg} / \mathrm{m}^{3}$ (mice) and above, with half-lives increasing to 465 to 583 days in rats exposed to $10 \mathrm{mg} / \mathrm{m}^{3}$ of L-MWNT1020 and to 337 to 649 days in mice exposed to $10 \mathrm{mg} / \mathrm{m}^{3}$. Conditions for lung overload were achieved in the 3 and $10 \mathrm{mg} / \mathrm{m}^{3}$ dose groups, which is consistent with the extended clearance half-lives observed in those groups.

All core study rats and mice survived until the end of these studies, and there were no statistically significant differences in body weights in any exposed group relative to the respective chamber controls. There were no clinical findings related to exposure. Brown discoloration of the lungs was observed in most rats exposed to $3 \mathrm{mg} / \mathrm{m}^{3}$ of L-MWNT-1020 and in all rats exposed to $10 \mathrm{mg} / \mathrm{m}^{3}$ and male and female mice exposed to 3 or $10 \mathrm{mg} / \mathrm{m}^{3}$. In addition, the bronchial and mediastinal lymph nodes were enlarged and discolored (brown or gray) in all rats exposed to $10 \mathrm{mg} / \mathrm{m}^{3}$, in most rats exposed to $3 \mathrm{mg} / \mathrm{m}^{3}$, and in some rats exposed to $1 \mathrm{mg} / \mathrm{m}^{3}$. Brown discoloration of bronchial and mediastinal lymph nodes was observed in most exposed female mice and in all male mice exposed to 3 or $10 \mathrm{mg} / \mathrm{m}^{3}$. Lung weights of female 
rats exposed to $10 \mathrm{mg} / \mathrm{m}^{3}$ and male and female mice exposed to 3 and $10 \mathrm{mg} / \mathrm{m}^{3}$ were significantly greater than those of the respective chamber controls.

In the nose of mice, the incidences of accumulation of hyaline droplets in the olfactory epithelium were significantly increased in females exposed to $3 \mathrm{mg} / \mathrm{m}^{3}$ of L-MWNT-1020 and in males and females exposed to $10 \mathrm{mg} / \mathrm{m}^{3}$, and the incidences of this lesion in the respiratory epithelium were significantly increased in females exposed to $1 \mathrm{mg} / \mathrm{m}^{3}$ and in males and females exposed to 3 and $10 \mathrm{mg} / \mathrm{m}^{3}$. Nasal cavity lesions were not present in exposed rats. In the larynx, the incidences of laryngeal epiglottic squamous metaplasia were significantly increased in female rats and male mice exposed to $1 \mathrm{mg} / \mathrm{m}^{3}$, and in male and female rats and mice exposed to 3 and $10 \mathrm{mg} / \mathrm{m}^{3}$ compared to those in the respective chamber controls. In the lungs of rats and mice, the incidences of chronic inflammation were significantly increased in males and females exposed to 1,3 , and $10 \mathrm{mg} / \mathrm{m}^{3}$. Alveolar epithelial hyperplasia was observed in three male and two female rats exposed to $1 \mathrm{mg} / \mathrm{m}^{3}$ and in all male and female rats in the 3 and $10 \mathrm{mg} / \mathrm{m}^{3}$ exposure groups. Bronchiolar epithelial hyperplasia occurred in only male and female mice exposed to 3 and $10 \mathrm{mg} / \mathrm{m}^{3}$, and the incidences were significantly increased compared to those in the chamber controls. The incidences of alveolar proteinosis in females exposed to $3 \mathrm{mg} / \mathrm{m}^{3}$ and in male and female mice exposed to $10 \mathrm{mg} / \mathrm{m}^{3}$ were significantly increased compared to those in the chamber controls; this lesion was not present in exposed rats.

Lymphoid hyperplasia was observed in the bronchial and mediastinal lymph nodes of exposed male and female rats and mice. The incidences of lymphoid hyperplasia in both lymph nodes were significantly increased in the male rats exposed to 3 and $10 \mathrm{mg} / \mathrm{m}^{3}$ of L-MWNT-1020 (except bronchial lymph node in the $10 \mathrm{mg} / \mathrm{m}^{3}$ dose group) and in female rats, as was the incidence in the mediastinal lymph node of female rats exposed to $1 \mathrm{mg} / \mathrm{m}^{3}$. In mice, lymphoid hyperplasia of the bronchial and mediastinal lymph nodes occurred in males exposed to 1,3 , and $10 \mathrm{mg} / \mathrm{m}^{3}$ but not in chamber controls. The incidence of bronchial lymphoid hyperplasia in males exposed to $3 \mathrm{mg} / \mathrm{m}^{3}$ was significantly increased compared to that in the chamber controls. In female mice, lymphoid hyperplasia of the bronchial and mediastinal lymph nodes occurred in the 1,3 , and $10 \mathrm{mg} / \mathrm{m}^{3}$ dose groups; one control female had lymphoid hyperplasia in the bronchial lymph node. In females exposed to $10 \mathrm{mg} / \mathrm{m}^{3}$, the incidences in both lymph nodes were significantly increased compared to those in the chamber controls.

The most severe respiratory tract lesions occurred in rats and mice exposed to concentrations that caused lung overload ( $3 \mathrm{mg} / \mathrm{m}^{3}$ and above). Exposure to concentrations below $3 \mathrm{mg} / \mathrm{m}^{3}$ caused many of these same lesions, although at lower incidences and severity. Relative to chamber controls, there were no significantly increased incidences of lesions in the respiratory tract of animals exposed to $0.3 \mathrm{mg} / \mathrm{m}^{3}$ or lower. Consistent with these results, $0.3 \mathrm{mg} / \mathrm{m}^{3}$ is considered the no-observed-adverse-effect level for L-MWNT-1020. 
Summary of Findings Considered to Be Toxicologically Relevant in Rats and Mice Exposed to 1020 Long Multiwalled Carbon Nanotubes by Inhalation for 30 Days

\begin{tabular}{|c|c|c|c|c|}
\hline & $\begin{array}{l}\text { Male Sprague } \\
\text { Dawley Rats }\end{array}$ & $\begin{array}{l}\text { Female Sprague } \\
\text { Dawley Rats }\end{array}$ & $\begin{array}{l}\text { Male B6C3F1/N } \\
\text { Mice }\end{array}$ & $\begin{array}{c}\text { Female B6C3F1/N } \\
\text { Mice }\end{array}$ \\
\hline Concentrations in Air & $\begin{array}{l}0,0.1,0.3,1,3 \\
10 \mathrm{mg} / \mathrm{m}^{3}\end{array}$ & $\begin{array}{l}0,0.1,0.3,1,3 \\
10 \mathrm{mg} / \mathrm{m}^{3}\end{array}$ & $\begin{array}{l}0,0.1,0.3,1,3 \\
10 \mathrm{mg} / \mathrm{m}^{3}\end{array}$ & $\begin{array}{l}0,0.1,0.3,1,3 \\
10 \mathrm{mg} / \mathrm{m}^{3}\end{array}$ \\
\hline Survival Rates & $\begin{array}{l}10 / 10,10 / 10 \\
10 / 10,10 / 10 \\
10 / 10,10 / 10\end{array}$ & $\begin{array}{l}10 / 10,10 / 10, \\
10 / 10,10 / 10, \\
10 / 10,10 / 10\end{array}$ & $\begin{array}{l}10 / 10,10 / 10, \\
10 / 10,10 / 10, \\
10 / 10,10 / 10\end{array}$ & $\begin{array}{l}10 / 10,10 / 10,10 / 10 \\
10 / 10,10 / 10,10 / 10\end{array}$ \\
\hline Clinical Observations & None & None & None & None \\
\hline Body Weights & $\begin{array}{l}\text { Exposed groups } \\
\text { similar to chamber } \\
\text { control group }\end{array}$ & $\begin{array}{l}\text { Exposed groups } \\
\text { similar to chamber } \\
\text { control group }\end{array}$ & $\begin{array}{l}\text { Exposed groups } \\
\text { similar to chamber } \\
\text { control group }\end{array}$ & $\begin{array}{l}\text { Exposed groups } \\
\text { similar to chamber } \\
\text { control group }\end{array}$ \\
\hline \multicolumn{5}{|l|}{ Lung Burden } \\
\hline Day 0 ( $\mu$ g L-MWNT-1020/lung) ${ }^{\mathrm{a}}$ & $\begin{array}{l}7.4,23,102,278 \\
698\end{array}$ & $\begin{array}{l}6.1,20,87,244 \\
652\end{array}$ & $1.4,4,15,43,111$ & $1.4,3,16,40,110$ \\
\hline $\mathbf{t}_{1 / 2}($ days $)$ & $52,64,90,160,465$ & $54,53,76,176,583$ & $96,47,82,293,337$ & $70,53,54,448,649$ \\
\hline Organ Weights & None & Lung & Lung & Lung \\
\hline Nonneoplastic Effects & $\begin{array}{l}\text { Larynx: epiglottis, } \\
\text { metaplasia, } \\
\text { squamous }(0 / 10, \\
0 / 10,0 / 10,1 / 10, \\
9 / 10,9 / 10) \\
\text { Lung: } \\
\text { inflammation, } \\
\text { chronic }(5 / 10,1 / 10, \\
\text { 2/10, 10/10, 10/10, } \\
\text { 10/10); alveolar } \\
\text { epithelium, } \\
\text { hyperplasia }(0 / 10, \\
0 / 10,0 / 10,3 / 10, \\
10 / 10,10 / 10) \\
\text { Lymph node, } \\
\text { bronchial: } \\
\text { hyperplasia, } \\
\text { lymphoid }(0 / 6,0 / 6, \\
\text { 0/9, 0/7, 6/7, 2/7) } \\
\text { Lymph node, } \\
\text { mediastinal: } \\
\text { hyperplasia, } \\
\text { lymphoid }(0 / 7,3 / 9, \\
1 / 10,3 / 9,8 / 9,9 / 10)\end{array}$ & $\begin{array}{l}\text { Larynx: epiglottis, } \\
\text { metaplasia, } \\
\text { squamous }(0 / 10, \\
\text { 1/10, } 0 / 10,6 / 10, \\
\text { 9/10, 7/10) } \\
\text { Lung: } \\
\text { inflammation, } \\
\text { chronic }(0 / 10,3 / 10, \\
\text { 2/10, 6/10, 10/10, } \\
\text { 10/10); alveolar } \\
\text { epithelium, } \\
\text { hyperplasia }(0 / 10, \\
0 / 10,0 / 10,2 / 10, \\
\text { 10/10, 10/10) } \\
\text { Lymph node, } \\
\text { bronchial: } \\
\text { hyperplasia, } \\
\text { lymphoid }(0 / 7,1 / 6, \\
\text { 0/4, 2/6, 6/7, } 7 / 9) \\
\text { Lymph node, } \\
\text { mediastinal: } \\
\text { hyperplasia, } \\
\text { lymphoid }(2 / 10, \\
\text { 3/10, 3/9, } 7 / 10, \\
9 / 10,10 / 10)\end{array}$ & $\begin{array}{l}\text { Larynx: epiglottis, } \\
\text { metaplasia, } \\
\text { squamous }(1 / 9, \\
\text { 2/10, 3/10, 6/10, } \\
\text { 9/10, 10/10) } \\
\text { Lung: } \\
\text { inflammation, } \\
\text { chronic }(0 / 10,0 / 10, \\
\text { 0/10, 8/10, 10/10, } \\
\text { 10/10); alveolus, } \\
\text { proteinosis }(0 / 10, \\
\text { 0/10, 0/10, 0/10, } \\
\text { 3/10,10/10); } \\
\text { bronchiole, } \\
\text { epithelium, } \\
\text { hyperplasia }(0 / 10, \\
\text { 0/10, 0/10, } 0 / 10, \\
7 / 10,10 / 10) \\
\text { Lymph node, } \\
\text { bronchial: } \\
\text { hyperplasia, } \\
\text { lymphoid }(0 / 6,0 / 9, \\
\text { 0/7, } 2 / 7,5 / 9,3 / 7) \\
\text { Nose: olfactory } \\
\text { epithelium, } \\
\text { accumulation, } \\
\text { hyaline droplet } \\
\text { (0/10, 0/10, } 0 / 10, \\
\text { 0/10, 2/10, 9/10); } \\
\text { respiratory } \\
\text { epithelium, } \\
\text { accumulation, } \\
\text { hyaline droplet } \\
\text { (0/10, 0/10, 0/10, } \\
\text { 3/10, 9/10, 10/10) }\end{array}$ & $\begin{array}{l}\text { Larynx: epiglottis, } \\
\text { metaplasia, squamous } \\
(1 / 10,1 / 10,1 / 10, \\
\text { 4/10, 6/10,10/10) } \\
\text { Lung: inflammation, } \\
\text { chronic }(0 / 10,0 / 10, \\
\text { 0/10, 4/10, 10/10, } \\
\text { 10/10); alveolus, } \\
\text { proteinosis }(0 / 10, \\
\text { 0/10, 0/10, 0/10, } 9 / 10, \\
\text { 10/10); bronchiole, } \\
\text { epithelium, } \\
\text { hyperplasia }(0 / 10, \\
0 / 10,0 / 10,0 / 10,6 / 10, \\
\text { 10/10) } \\
\text { Lymph node, } \\
\text { bronchial: hyperplasia, } \\
\text { lymphoid }(1 / 9,0 / 3, \\
\text { 0/8, } 2 / 9,3 / 6,5 / 6) \\
\text { Lymph node, } \\
\text { mediastinal: } \\
\text { hyperplasia, lymphoid } \\
(0 / 7,0 / 8,0 / 8,1 / 7, \\
\text { 1/10, 5/9) } \\
\text { Nose: olfactory } \\
\text { epithelium, } \\
\text { accumulation, hyaline } \\
\text { droplet }(0 / 10,0 / 10, \\
\text { 1/10, 3/10, } 8 / 10, \\
\text { 10/10); respiratory } \\
\text { epithelium, } \\
\text { accumulation, hyaline } \\
\text { droplet }(0 / 10,0 / 10, \\
0 / 10,8 / 10,10 / 10, \\
\text { 10/10) }\end{array}$ \\
\hline
\end{tabular}

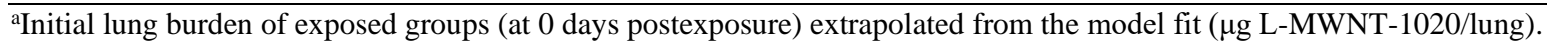




\section{Introduction}

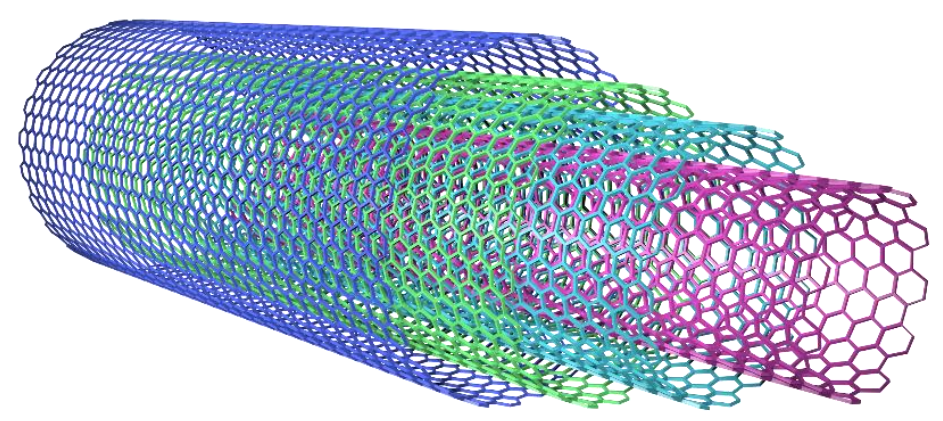

Figure 1. Multiwall Carbon Nanotube Structure

\section{Chemical and Physical Properties}

Carbon nanotubes (CNT) are highly ordered hexagonal lattices of carbon atoms arranged into cylinders by hydrogen bonding, dipolar forces, hydrophilic or hydrophobic interactions, gravity, and other forces ${ }^{1}$. A single-wall carbon nanotube (SWCNT) has been described as a single sheet of graphene rolled to form a seamless nanoscale cylinder ${ }^{2}$. Multiwalled carbon nanotubes (MWCNTs), such as 1020 Long Multiwalled Carbon Nanotube (L-MWNT-1020), consist of many SWCNTs, one inside of another, and held together by van der Waals bonding. MWCNTs exhibit superior mechanical, chemical, electronic, and optical properties and are highly stable and chemically unreactive. MWCNTs are thermally stable up to $2800^{\circ} \mathrm{C}$ in vacuum; thermal conductivity is approximately twice that of diamond, and electric current carrying capacity is 1,000 times higher than copper wires ${ }^{3}$.

The chemical and physical characteristics of MWCNTs vary significantly depending on the production method and postsynthesis processing. Unpurified MWCNTs typically contain amorphous carbon contaminants, SWCNTs, and residual metal catalysts. Metal catalysts such as iron and nickel can be present at $30 \%$ or greater by mass ${ }^{4}$. MWCNT may also be contaminated with magnesium oxides, aluminates, and silicates that are often used to support the catalyst or growth region ${ }^{2}$. Although MWCNTs are generally purified to remove these contaminants, varying amounts remain in the final material. Purification procedures can also add additional contaminants such as carboxylic acid residues ${ }^{2}$. The ability to functionalize MWCNTs by the addition of specific functional groups to the carbon lattice can result in significant changes in the chemical and physical properties. Functionalization has been used to optimize solubility, dispersion, conductivity, and other properties of the $\mathrm{MWCNT}^{5}$ resulting in a wide array of applications.

The physical dimensions of MWCNTs depend on the synthesis method. The diameters of MWCNTs depend on the number of encapsulated tubes and can range from 10 to $100 \mathrm{~nm}^{6}$. The lengths of MWCNTs are generally dependent on synthesis time and can be tens of micrometers long ${ }^{7}$. Some MWCNT can assemble into low-density agglomerates of intertwined and entangled tubules due to the attraction of van der Waals forces. The structure and size of these 
agglomerates is determined primarily by the dimensions of the MWCNT. Flexible, thin-walled MWCNTs more readily assemble into agglomerates than rigid, thick-walled MWCNTs.

\section{Production, Use, and Human Exposure}

MWCNTs are synthesized by applying energy to a carbon source producing individual or groups of carbon atoms that reassemble into tubes. Common methods of synthesis include chemical vapor deposition, laser ablation, arc discharge, and high-pressure carbon monoxide conversion. A metal catalyst (e.g., cobalt, iron, nickel, or molybdenum) is often used to reduce the synthesis temperature and increase the yield and homogeneity. Chemical vapor deposition is the primary method used for high volume production of MWCNTs ${ }^{8}$. MWCNTs also can occur as a byproduct of natural events, such as forest fires ${ }^{9}$, and industrial processes, such as combustion of propane and natural gas ${ }^{10}$.

More efficient and less costly production methods have resulted in large-scale production of CNTs with annual production capacities of some grades reaching thousands of tons ${ }^{11}$. With the commercial availability of bulk quantities of CNTs, there are increasing numbers of industries to explore new commercial opportunities. The global production of MWCNTs and SWCNTs increased more than 10-fold between 2006 and $2012^{8}$. MWCNTs are produced in far greater numbers than are SWCNTs ${ }^{12}$ because of their lower production cost and because their use in composite materials requires greater volume. In 2014, worldwide commercial MWCNT production commitment (Tier 1 companies) was 1,445 tons and was predicted to reach 4,195 tons by $2019^{11}$.

One of the largest uses of MWCNTs is in nanotube-reinforced polymer composite materials ${ }^{8}$. The exceptional mechanical properties and low density of MWCNTs make them ideal for application to products requiring load-bearing strength and durability. MWCNT powders are mixed with polymers or resins to improve stiffness, strength, and toughness ${ }^{13}$. The MWCNTcomposite market has the potential to expand significantly as methods improve and more applications are discovered. Other commercial applications for MWCNT include use in batteries, automotive parts, sporting goods, boat hulls, water filters, thin-film electronics, coatings, actuators, and electromagnetic fields ${ }^{8}$. Functionalized MWCNTs have been investigated for potential use as nanocarriers for targeted drug or biomolecule delivery because of their small size, high loading capacity, and functional surface chemistry ${ }^{14}$. Functionalized MWCNTs show great promise in biomedical applications, such as gene/drug delivery, bacterial filters, molecular diagnoses, cancer and infection treatments, and bone tissue engineering ${ }^{15-21}$.

Human exposure to MWCNTs occurs primarily in the workplace. Because MWCNT production and use are relatively recent and numbers of potentially exposed workers are small, only limited occupational exposure data are available. A number of studies, including some sponsored by NTP, demonstrated the potential of occupational exposure to MWCNT ${ }^{22-32}$. Most of these studies were conducted in small research and development facilities where only small amounts of MWCNTs are synthesized and handled. Worker exposure to MWCNT can occur during the transfer, weighing, blending, and mixing of the bulk powders, and during the machining of MWCNT-composite materials ${ }^{33}$. Low levels of exposure can occur during disposal and recycling of materials containing $\mathrm{MWCNT}^{34}$. In general, these studies provide evidence that exposure of workers to MWCNT can occur, especially where exposure control measures have not been implemented. However, assessment of exposure concentrations is difficult due to the limited 
amount of exposure data, the lack of specific and sensitive methods for analyzing MWCNT, and the heterogeneity of exposure conditions.

\section{Regulatory Status}

The Occupational Safety and Health Administration ${ }^{35}$ recommended that worker exposure to respirable carbon nanotubes and carbon nanofibers not exceed $1.0 \mu \mathrm{g} / \mathrm{m}^{3}$ as an 8 -hour time-weighted average in accordance with the National Institute for Occupational Safety and Health (NIOSH) proposed recommended exposure limit (REL). The NIOSH REL was derived using published subchronic and short-term animal studies with dose-response data of early stage fibrotic and inflammatory lung responses to CNT exposure ${ }^{36}$.

\section{Toxicokinetics}

Studies of MWCNT pharmacokinetics in humans were not found in the literature. Only limited animal data were available and were difficult to evaluate due to the heterogeneity of MWCNT studied and methodological differences. Pharmacokinetic studies of MWCNTs in animals have focused on systemic exposure following oral or intravenous administration of functionalized CNTs, primarily SWCNTs. Toxicokinetic studies of MWCNTs in animals have focused on pulmonary exposure because this is the most relevant for human exposure. In the majority of these studies, MWCNTs were administered by intratracheal instillation (rats) or oropharyngeal aspiration (mice). These nonphysiological routes of administration entail a single bolus dose of MWCNTs suspended in liquid media. The toxicokinetics and fate of particles administered by these routes are different than those following inhalation ${ }^{37 ; 38}$.

Because purified (synthetic biproducts removed) MWCNTs are highly stable and chemically unreactive, absorption and metabolism in the body are not major concerns. The primary toxicokinetic considerations for MWCNTs are distribution and clearance in the respiratory tract. Inhalation exposure to MWCNTs is a major concern because of the small respirable size and limited solubility. Single MWCNTs or agglomerates with mass median aerodynamic diameters (MMAD) of less than about $5 \mu \mathrm{m}$ can be distributed throughout the human respiratory tract, including the alveoli, whereas larger particles are deposited in the nose and upper airways. Micrometer-sized particulate matter in the alveoli is cleared following phagocytosis by alveolar macrophages and then transported via the mucociliary escalator to the gastrointestinal tract or by translocation to the draining lung-associated lymph nodes ${ }^{39}$. Several studies have reported the presence of MWCNT in subpleural tissues following inhalation exposure ${ }^{40-42}$.

Poorly soluble particles with a high aspect ratio like MWCNTs are not easily phagocytized and are cleared slowly by alveolar macrophages ${ }^{43 ; 44}$. Failure to fully phagocytize long MWCNT (e.g., in which the MWCNT length is greater than macrophage diameter) can result in release of degradative lysosomal enzymes into the interstitium causing damage to nearby cells ${ }^{45 ; 46}$. Macrophage function and clearance also can become impaired when ingested particles occupy more than $6 \%$ of the macrophage volume ${ }^{47 ; 48}$. When MWCNT deposition exceeds clearance, the lung burden increases and results in lung overload and toxicity.

The kinetics of MWCNTs in the lung and lung-associated lymph nodes of male Wistar rats were investigated during a nose-only inhalation exposure to $\mathrm{MWCNT}^{49}$. Animals (six per group) were exposed 6 hours per day, 5 days per week for 13 consecutive weeks to $0,0.1,0.4,1.5$, or 
$6 \mathrm{mg} / \mathrm{m}^{3}$ MWCNT (Baytubes ${ }^{\circledR}$; Bayer MaterialScience, Leverkusen, Germany). Individual MWCNT contained $0.115 \%$ cobalt and were approximately $10 \mathrm{~nm}$ in diameter and 200 to $300 \mathrm{~nm}$ in length; however, MWCNT dispersed into the inhalation chambers were primarily agglomerates of tangled and intertwined MWCNT that were 2 to $3 \mu \mathrm{M}$ in diameter. The left lung and lung-associated lymph nodes were collected and analyzed for cobalt as a marker of exposure during weeks 8, 13, 17, 26, and 39. Minimal to moderate lung overload occurred in the animals exposed to 0.1 and $0.4 \mathrm{mg} / \mathrm{m}^{3}$, whereas impaired clearance to complete stasis appeared to occur at 1.5 and $6 \mathrm{mg} / \mathrm{m}^{3}$. A time- and concentration-dependent increase of cobalt in the lungassociated lymph nodes occurred at 1.5 and $6 \mathrm{mg} / \mathrm{m}^{3}$ during the postexposure period (weeks 17 , 26 , and 39) ${ }^{49}$.

In another study, male C57B1/6 mice were exposed by inhalation to $5 \mathrm{mg} / \mathrm{m}^{3} \mathrm{MWCNT}-7$ (Mitsui-7; Hodogaya Chemical Company, Ltd., Tokyo, Japan ${ }^{41}$. MWCNT-7 carbon nanotubes are relatively short ( 1 to $19 \mu \mathrm{m}$ ), thick (40 to $170 \mathrm{~nm}$ ) and rigid. Mice were exposed 5 hours per day, 4 days per week for 3 weeks, and the MWCNT distribution and lung burden were evaluated at $1,14,28,84,168$, and 336 days postexposure ${ }^{41}$. Initially, $84 \%$ of the MWCNT were in the alveolar region (including $1.2 \%$ in the subpleural region) and $16 \%$ in the airways. At 336 days postexposure, $95.8 \%$ of the initial lung burden remained in the alveolar region (including $4.8 \%$ in subpleural region) and $4.2 \%$ were found in the airways. Burden in the airways decreased rapidly postexposure and reached a steady state by 14 days postexposure. Initially, most of the MWCNT in the alveolar region were present in alveolar macrophages. Clearance occurred most rapidly in the alveolar macrophage fraction followed by the alveolar tissue. Overall, MWCNT lung burden decreased with postexposure time. Agglomerates of MWCNT (greater than four MWCNT per agglomerate) accounted for the majority of MWCNT cleared from the lung, whereas the burden present as single MWCNT remained unchanged ${ }^{41}$.

\section{Toxicity}

The toxic properties of MWCNTs are dependent on their functionalization, dispersibility and aggregation, biopersistence, route of exposure, and dose. Concerns for the toxicity of MWCNTs are because of their submicron size, their fiber-like geometry, and biopersistence ${ }^{50}$.

\section{Experimental Animals}

Although inhalation is the most relevant route of human exposure to MWCNTs, few subchronic inhalation studies have been conducted in laboratory animals. Mitchell et al.$^{51}$ conducted inhalation studies in C57B1/6 mice at low exposure concentrations $\left(0.3\right.$ to $\left.5 \mathrm{mg} / \mathrm{m}^{3}\right)$ of respirable MWCNT 6 hours per day for up to 2 weeks. MWCNTs (Shenzhen Nanotech Port Company, Shenzhen, China) were about 10 to $20 \mathrm{~nm}$ in diameter and 5 to $15 \mu \mathrm{m}$ in length and existed primarily as aggregates less than $1 \mu \mathrm{m}$ diameter. MWCNT exposure did not cause inflammation or histopathologic lesions in the lungs; however, a systemic immunosuppression was observed in mice at all exposure concentrations when evaluated at 14 days. Immunosuppression was not exposure concentration-related and was characterized by a reduced T-cell dependent antibody response to sheep red blood cells and a reduced T-cell proliferative capacity in response to the mitogen Concanavalin A.

A single 6-hour exposure of C57B1/6 mice to $30 \mathrm{mg} / \mathrm{m}^{3}$ of MWCNT (Helix Material Solutions, Richardson, TX; length of 0.5 to $50 \mu \mathrm{m}$; MMAD of $0.183 \mu \mathrm{m}$ ) resulted in a clear increase in 
subpleural fibrosis at 2 and 6 weeks postexposure ${ }^{40}$. MWCNT were observed within alveolar macrophages, subpleural mesenchymal cells, and the subpleural collagen matrix. Mononuclear cell aggregates containing macrophages with engulfed MWCNT were present on the pleural surface of mice exposed to $30 \mathrm{mg} / \mathrm{m}^{3}$ when evaluated 1 day and 2 weeks postexposure.

Wistar Han rats were exposed to MWCNT (Nanocyl ${ }^{\circledR}$ NC $7000^{\mathrm{TM}}$, Sambreville, Belgium) aerosols 6 hours per day, 5 days per week for 13 weeks at concentrations of $0.1,0.5$, or $2.5 \mathrm{mg} / \mathrm{m}^{352}$. Examination of the test atmospheres revealed that animals were exposed to agglomerates ranging from 0.7 to $2.0 \mu \mathrm{m}$ MMAD. Treatment-related lesions were present in the nasal cavity, larynx, trachea, lungs, and mediastinal lymph nodes. Except for a slight neutropenia at $2.5 \mathrm{mg} / \mathrm{m}^{3}$, there was no evidence of extrapulmonary toxicity. Increased lung weights, multifocal granulomatous inflammation, diffuse histiocytic and neutrophilic inflammation, and intra-alveolar lipoproteinosis were observed in the lung and lung-associated lymph nodes at 0.5 and $2.5 \mathrm{mg} / \mathrm{m}^{3}$. The incidence and severity of these effects were related to exposure concentration.

Ellinger-Ziegelbauer ${ }^{53}$ and Pauluhn ${ }^{54}$ compared the pulmonary toxicity of Baytubes (Bayer MaterialScience, Leverkusen, Germany) containing $0.53 \%$ cobalt and metal-depleted Baytubes containing $0.12 \%$ cobalt. Baytubes are a thin-walled MWCNT with a mean diameter of 10 to $16 \mathrm{~nm}$ and a mean length of 200 to $300 \mathrm{~nm}$, and form coiled tangled agglomerates. Baytubes were micronized to a respirable size ( 2 to $3 \mu \mathrm{m}$ MMAD) prior to use. $\alpha$-Quartz $(2.3 \mu \mathrm{m}$ MMAD) was used as a reference dust for particle-induced toxicity. Male Wistar rats were exposed to either air, Baytubes $\left(11\right.$ or $\left.241 \mathrm{mg} / \mathrm{m}^{3}\right)$, depleted Baytubes $\left(11 \mathrm{mg} / \mathrm{m}^{3}\right)$, or $\alpha$-quartz $\left(248 \mathrm{mg} / \mathrm{m}^{3}\right)$ for 6 hours by nose-only inhalation followed by a 3-month postexposure period. Baytubes caused concentration-dependent pulmonary inflammation that decreased with time after exposure. Inflammation was characterized by increased bronchoalveolar lavage fluid (BALF) cellularity, lactate dehydrogenase (LDH) activity, protein, and collagen, enlarged and/or foamy macrophages, and upregulation of lung inflammatory cytokines and chemokines. The timecourse of inflammation was the same for Baytubes and metal-depleted Baytubes; $\alpha$-quartz caused more progressive inflammatory changes over time. The authors concluded that the pulmonary inflammatory response to MWCNT is primarily dependent on the assemblage structure and not metal impurities.

In a subsequent study, Pauluhn ${ }^{49}$ investigated the inhalation toxicity and lung clearance of Baytubes in male and female Wistar Han rats following nose-only inhalation exposure to 0, 0.1, $0.4,1.5$ or $6 \mathrm{mg} / \mathrm{m}^{3} 6$ hours per day, 5 days per week, for 13 weeks. Lung and lung-associated lymph node weights were increased in rats exposed to $0.4 \mathrm{mg} / \mathrm{m}^{3}$ or greater. Exposure-related histopathologic lesions were present in the nasal cavity, lung, and lung-associated lymph nodes of rats exposed to $0.4 \mathrm{mg} / \mathrm{m}^{3}$ or greater. No lesions were found in extrapulmonary tissues. Lung burden data indicated that minimal to moderate lung overload occurred at 0.1 and $0.4 \mathrm{mg} / \mathrm{m}^{3}$, whereas impaired clearance to complete stasis may have occurred at 1.5 and $6 \mathrm{mg} / \mathrm{m}^{3}$.

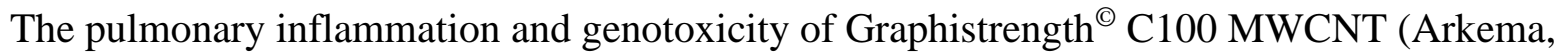
Colombes, France) was investigated in a 90-day nose-only inhalation study in male and female Wistar rats ${ }^{55}$. Graphistrength ${ }^{\odot} \mathrm{C} 100$ consists of large agglomerates of entangled MWCNT and was micronized prior to use to provide respirable-size particles (mean diameter of 11 to $12 \mathrm{~nm}$; mean length of approximately $1 \mu \mathrm{m}$; MMAD of 1.6 to $2.3 \mu \mathrm{m}$ ). Rats were exposed to $0,0.05$, 0.25 , or $5 \mathrm{mg} / \mathrm{m}^{3}$ for 90 days followed by a 90 -day recovery period. Twenty-four hours and 
90 days after the 90-day exposure, 10 rats per sex per concentration were sacrificed for BALF measurements (left lung only) and histopathology. Numbers of macrophages decreased and neutrophil numbers increased in BALF at 24 hours after exposure to 0.25 and $5 \mathrm{mg} / \mathrm{m}^{3}$, and at 90 days postexposure to $5 \mathrm{mg} / \mathrm{m}^{3}$. BALF levels of phospholipids, $\mathrm{LDH}$, alkaline phosphatase, gamma-glutamyl transferase, and protein were elevated at 24 hours and 90 days postexposure in rats exposed to $5 \mathrm{mg} / \mathrm{m}^{3}$. A prolonged release of TNF- $\alpha$ in BALF was observed at 0.25 and $5 \mathrm{mg} / \mathrm{m}^{3}$. An increase in interstitial collagen staining was observed at $5 \mathrm{mg} / \mathrm{m}^{3}$, similar to that reported following exposure of rats to Baytube ${ }^{\circledR} \mathrm{MWCNT}^{49}$. Other histopathologic changes noted at 90 days postexposure were eosinophilic inclusions in respiratory and olfactory epithelium in the nose, minimal squamous metaplasia in the larynx, and increased lymphocytes in the tracheobronchial lymph nodes. No pleural effects were observed. After 90 days of recovery, clearance of MWCNT particles was observed in the 0.5 and $0.25 \mathrm{mg} / \mathrm{m}^{3}$ groups; however, particle clearance was unchanged at 90 days postexposure in the $5 \mathrm{mg} / \mathrm{m}^{3}$ group, indicating an inhibition of clearance and lung overload. No exposure-related effects were observed on sperm counts, motility, and morphology 24 hours and 90 days postexposure. The results of genotoxicity assays (micronucleus test and comet assay) are discussed below.

A number of inhalation studies ${ }^{41 ; 42 ; 56}$ have been conducted on MWCNT-7 (Mitsui-7, Hodogaya Chemical Company, Ltd.). MWCNT-7 carbon nanotubes are relatively short (1 to $19 \mu \mathrm{m}$ ) and thick (40 to $170 \mathrm{~nm}$ ) with structures that range from single nanotubes to agglomerates with a MMAD of $1.5 \mu \mathrm{m}$. Because of their fiber-like dimensions and rigidity, many studies have examined the ability of MWCNT-7 to penetrate the pleural wall and cause pulmonary toxicity and mesothelioma.

Porter et al. ${ }^{42}$ investigated the acute pulmonary toxicity of MWCNT-7 in male C57B1/6 mice after exposure to $10 \mathrm{mg} / \mathrm{m}^{3}$ MWCNT-7 for 5 hours per day for $2,4,8$, or 12 days. MWCNT-7 lung burden was linearly related to exposure concentration. MWCNT-7 were most frequently deposited in the bronchioles and proximal alveolar regions of exposed mice and at the pleural wall in two exposed mice. Exposure concentration-dependent increases in lung inflammation and cytotoxicity were indicated on day 1 by increases in BALF neutrophils and LDH levels. Histopathologic lesions in lungs of exposed mice included bronchiolocentric inflammation, bronchiolar epithelial cell hyperplasia and hypertrophy, minimal to mild fibrosis, vascular changes, and pleural penetration by MWCNT-7 in two mice.

A 13-week inhalation study of MWCNT-7 was conducted in male and female Fischer 344 rats $^{56}$. Rats were exposed to $0.2,1.0$, or $5 \mathrm{mg} / \mathrm{m}^{3}$ MWCNT-7 for 6 hours per day, 5 days per week for 13 weeks. Lung weights were increased 1.2 -fold at $1 \mathrm{mg} / \mathrm{m}^{3}$ and 1.3 -fold at $5 \mathrm{mg} / \mathrm{m}^{3}$ in male and female rats relative to controls. Inflammatory cytokines were increased in the BALF in an exposure concentration-dependent manner beginning at $2 \mathrm{mg} / \mathrm{m}^{3}$. Granulomatous changes were present in the lungs of male rats at all exposure concentrations and in females at 1 and $5 \mathrm{mg} / \mathrm{m}^{3}$. Focal fibrosis of the alveolar wall was present in both sexes exposed to $1 \mathrm{mg} / \mathrm{m}^{3}$ and higher. Inflammatory infiltration of the visceral pleura and subpleural areas was observed in the $5 \mathrm{mg} / \mathrm{m}^{3}$ exposure group.

Mercer et al. ${ }^{41}$ investigated the distribution and fibrotic response following whole-body exposure of male C57Bl/6J mice to $5 \mathrm{mg} / \mathrm{m}^{3}$ MWCNT-7 for 5 hours per day for 12 days with necropsies at $1,14,84,168$, or 336 days postexposure. Pulmonary inflammation, characterized by increases in BALF neutrophils, LDH, and albumin peaked at postexposure day 1 and declined thereafter. 
Deposition of fibrillar collagen in the alveolar septa progressively increased over the 336 days postexposure. When examined at postexposure day 1, 84\% of the MWCNT-7 lung burden was in the alveolar region. Approximately $56 \%$ of the alveolar lung burden was in the alveolar macrophages, $7 \%$ in the alveolar spaces, and $20 \%$ in the alveolar tissue. By postexposure day 168 the macrophage burden had decreased by $35 \%$, whereas the alveolar tissue burden had increased by $63 \%$. Large aggregates of greater than four fibers accounted for most of the cleared MWCNT-7. The amount of single fibers in the alveolar region remained unchanged and was reportedly responsible for the progressive fibrosis up to 336 days postexposure.

A number of MWCNT toxicity studies have been conducted in which MWCNT were administered to the lungs of laboratory animals by intratracheal instillation or oropharyngeal aspiration. Although these studies provide some information on potential mechanisms, the nonphysiological administration of a bolus dose of MWCNT suspended in a dispersion medium makes these studies difficult to interpret with respect to toxicity following inhalation exposure. Administration of MWCNT by these routes often results in greater lung inflammation, granulomas, and fibrosis than would occur following inhalation ${ }^{57-60}$. In addition, a large number of in vitro studies of MWCNT have been reported. In vitro studies have provided important information on MWCNT solubility and durability, cell surface interactions, and toxicity of metal impurities. However, in vitro toxicity studies have produced a wide spectrum of results due to different MWCNT tested, differences in MWCNT preparation, high doses, cell types used, and a wide variety of test methods ${ }^{61}$.

\section{Humans}

Few studies have evaluated the potential toxicity of MWCNT in humans in part because of low numbers of exposed workers and methodologic limitations. A small cross-sectional study recently was conducted at a large-scale MWCNT manufacturing plant with relatively high occupational exposures to evaluate potential biomarkers of exposure ${ }^{62}$. Personal breathing zone samples were collected from specific workplaces and analyzed for elemental carbon and particle analysis by transmission electron microscopy. Nasal lavage fluid, induced sputum, and serum were collected from exposed and nonexposed workers and analyzed for biomarkers of inflammation and fibrosis. Blood was collected for measurement of global messenger ribonucleic acid (mRNA) and noncoding RNA (ncRNA) expression. Significant increases were detected in interleukin-1 $\beta$, interleukin-6, tumor necrosis factor- $\alpha$, inflammatory cytokines, and Kerbs von Lungren-6, a serologic marker for interstitial lung disease in induced sputum. Transforming growth factor- $\beta$, a profibrotic cytokine, was increased in the serum of exposed workers. Significant changes in the mRNA and ncRNA expression profiles were detected in the blood of exposed workers ${ }^{63}$. A set of microRNAs with roles in cell cycle regulation/progression/control, apoptosis and proliferation were identified. Particle morphology was identified as agglomerates ranging from 0.5 to $10 \mu \mathrm{m}$ in diameter; individual nanotubes were not observed. The individual time-weighted average concentration of respirable elemental carbon (not specific for MWCNT) was as high as $2.8 \mathrm{mg} / \mathrm{m}^{3}$, nearly three times the NIOSH REL, indicating a potential health risk at this exposure concentration particularly with extended exposures.

An exposure assessment conducted at CNT manufacturing plants also evaluated several health endpoints in exposed workers. Lee et al. ${ }^{64}$ examined nine manufacturing workers and four office workers at a large-scale manufacturing facility which produced MWCNT. Exhaled breath condensate (EBC) was used to monitor the potential effects of MWCNT exposures on 
inflammatory and oxidative stress in the respiratory tract. Particle sizes ranged from approximately 8 to $300 \mathrm{~nm}$ in diameter (lengths were not reported). The respirable particle concentrations were estimated to be 1.6 to $2.3 \mathrm{mg} / \mathrm{m}^{3}$. The pulmonary function tests and hematology and serum chemistry values in both office and manufacturing workers were reported to be in the normal ranges. Some EBC biomarkers of oxidative stress (i.e., malondialdehyde , 4hydroxy-2-hexanal, and n-hexanal) were significantly higher in the manufacturing workers.

Levels of molybdenum were measured in the blood of workers because molybdenum was used as a catalyst in MWCNT manufacturing. Blood molybdenum levels were increased nonsignificantly in the manufacturing workers and were correlated positively with the EBC oxidative markers malondialdehyde and n-hexanol.

\section{Reproductive and Developmental Toxicity}

No reproductive or developmental toxicity studies in experimental animals or case studies in humans were found in the literature.

\section{Carcinogenicity}

\section{Experimental Animals}

Currently, only one chronic inhalation study in laboratory animals has been conducted to evaluate the potential carcinogenicity of $\mathrm{MWCNT}^{65}$. Groups of 50 6-week old F344/DuCrlCrlj rats of each sex were exposed to MWCNT-7 aerosol for 104 weeks ( 6 hours per day, 5 days per week) at concentrations of $0,0.02,0.2$, or $2 \mathrm{mg} / \mathrm{m}^{3}$. Samples collected from the inhalation chambers had an average width of 92.9 to $98.2 \mathrm{~nm}$ and length of 5.4 to $5.9 \mu \mathrm{m}$. Most MWCNT-7 fibers collected from the chambers were single straight fibers and were not aggregated.

MWCNT-7 exposure had no significant effect on survival, body weights, or urinary, hematologic, and blood biochemical analyses relative to chamber controls. The incidences of bronchoalveolar carcinomas, total carcinomas (bronchoalveolar carcinoma, adenosquamous carcinoma, adenocarcinoma, and squamous carcinoma) and total carcinomas and/or adenomas in males exposed to 0.2 or $2 \mathrm{mg} / \mathrm{m}^{3}$ and in females exposed to $2 \mathrm{mg} / \mathrm{m}^{3}$ were increased compared with their respective chamber control groups. Incidences of preneoplastic lesions (bronchoalveolar epithelial hyperplasia and atypical epithelial hyperplasia) were increased in the lungs of male and female rats in an exposure concentration-dependent manner. MWCNT-7 lung burden was determined for rats that were euthanized or died before the end of the 104-week study. The numbers of MWCNT-7 nanotubes in the lungs increased linearly with exposure concentration in males and females. The numbers of nanotubes per body weight were similar for males and females in the different exposed groups.

A two-stage initiation/promotion study was conducted to determine if inhaled MWCNT-7 can act as a complete carcinogen and/or promote the growth of cells with existing DNA damage ${ }^{66}$. Two groups of B6C3F1 mice were exposed to $5 \mathrm{mg} / \mathrm{m}^{3}$ MWCNT-7 or air, 5 hours per day, 5 days per week, for 15 days. Prior to MWCNT-7 exposure, half of the mice were treated with the 3-methylcholanthrene, a known tumor initiator. When examined 17 months postexposure, bronchoalveolar adenomas and adenocarcinomas were observed in $90.5 \%$ of the mice in the 3methylcholanthrene/MWCNT-7 group, $51.9 \%$ of 3-methylcholanthrene-only group, $26.5 \%$ of the MWCNT-7-only group, and $23 \%$ of the untreated chamber control group. Although these results 
do not indicate that MWCNT-7 alone can cause cancer, exposure to MWCNT-7 may increase the risk of cancer in mice exposed to a known carcinogen.

The fiber-like geometry and biopersistence of MWCNT has resulted in concern that MWCNT may cause mesothelioma similar to that caused by asbestos fibers ${ }^{2 ; 36}$. Consequently, many studies have been conducted to evaluate the potential of MWCNT to cause mesothelioma following injection into the peritoneal cavity (intraperitoneal injection) in animals. On the basis of the results of these studies, the International Agency for Research on Cancer (IARC) concluded that there was sufficient evidence of carcinogenicity in humans for MWCNT-7, and limited evidence for two other types of MWCNT with dimensions similar to MWCNT-7 ${ }^{67}$. MWCNT-7 caused peritoneal mesotheliomas in male and female rats in one intraperitoneal injection study and one intrascrotal injection study ${ }^{68}$, and in male $p 53+/-$ heterozygous mice in two intraperitoneal injection studies ${ }^{69 ; 70}$. Two other types of MWCNT with physical dimensions similar to those of MWCNT-7 ( 1 to $19 \mu \mathrm{m}$ long by 40 to $170 \mathrm{~nm}$ wide) caused mesotheliomas in male and female rats following intraperitoneal injection ${ }^{71}$. Although intraperitoneal injection is an accepted model for mesothelioma screening, this model does not replicate the toxicokinetics of inhaled MWCNT.

Rittinghausen et al. ${ }^{72}$ also used the intraperitoneal injection model to investigate whether four tailor-made MWCNT of different lengths, diameters, and curvatures could induce mesotheliomas similarly to asbestos fibers. Male Wistar Han (Crl:WI Han) rats (50 per group) received a single intraperitoneal injection of vehicle or one of four MWCNT at either $1 \times 10^{9}$ or $5 \times 10^{9}$ fibers per animal. MWCNT A and B (dimensions of $8.57 \mu \mathrm{m}$ long by $85 \mu \mathrm{m}$ wide, and $9.30 \mu \mathrm{m}$ long by $62 \mu \mathrm{m}$ wide, respectively) were of medium length with slightly larger diameters than MWCNT C and D. MWCNT C was a long thin fiber (10.24 $\mu \mathrm{m}$ long by $40 \mathrm{~nm}$ wide). MWCNT D was a thin fiber of medium length $(7.91 \mu \mathrm{m}$ long by $37 \mathrm{~nm}$ wide). A positive control group received an intraperitoneal injection of $1 \times 10^{8}$ long amosite asbestos fibers. Rats were held for 24 months following treatment, and then complete necropsies and histopathologic evaluations were performed. All four MWCNT in all dosed groups caused malignant mesotheliomas. Mesothelioma was detected in one (2\%) vehicle control animal and in $66 \%$ of asbestos-treated animals. The highest frequencies ( $90 \%$ to $98 \%$ of animals) and earliest appearances (5 to 6 months) of mesothelioma occurred with the two relatively straight MWCNT A and B. Mesotheliomas (84\% to $94 \%$ of animals) appeared only slightly later (6 to 10 months) in rats treated with MWCNT C. MWCNT D, the most curved nanotube, caused mesotheliomas (40\% to $70 \%$ of animals) later (11 to 20 months) in the 2 year study.

\section{Humans}

No data on the carcinogenicity of MWCNTs in humans were available. Because of the relatively recent production and use of MWCNT, worker exposures have been of relatively short duration. A few short-term studies have reported biomonitoring endpoints associated with exposure to MWCNTs; however, epidemiological studies designed to investigate the potential carcinogenicity of MWCNTs in humans have not been conducted. The carcinogenicity of CNTs was assessed by an IARC working group ${ }^{73}$. MWCNT-7 was classified as possibly carcinogenic to humans (Group 2B). The lack of evidence across the various distinct CNTs precluded generalization to other types of CNTs. SWCNTs and MWCNTs, excluding MWCNT-7, were categorized as not classifiable as to their carcinogenicity to humans (Group 3). 


\section{Genetic Toxicity}

Carbon nanotubes have been reported to produce genotoxic effects in vivo and in vitro, yet few studies have attempted to systematically identify the key physicochemical characteristics that are required for inducing genotoxicity. For extensive reviews on the challenges of evaluating carbon nanotubes in genetic toxicity tests and recommendations for testing, as well as proposed mechanisms of action in vivo and in vitro, see Magdolenova et al. ${ }^{74}$, IARC $^{73}$, Kuempel et al. ${ }^{75}$, and Møller and Jacobsen ${ }^{76}$. In general, the genotoxicity of carbon nanotubes has been attributed to formation of reactive oxygen species and interference with chromosome segregation. Carbon nanotubes have been tested in bacterial mutagenicity assays and have generally produced negative results; however, the use of these assays as part of a genetic toxicity testing battery for carbon nanotubes has been questioned, as nanotubes are unlikely to cross the cell wall.

Due to the heterogeneity of MWCNT, the following in vivo and in vitro genetic toxicology studies were reviewed depending on whether the tested material shared some characteristics with the National Toxicology Program (NTP) test article. Furthermore, in vivo studies were reviewed if inhalation was used as the route of exposure, similar to the NTP studies of L-MWNT-1020.

Three studies have evaluated the genotoxicity of MWCNT in rats exposed via inhalation. Two of these studies were performed by the same research group. In the first study, male Sprague Dawley rats underwent whole-body exposure to CM-95 MWCNT (Hanwha Nanotech, Inc. Incheon, Korea) for 5 days, 6 hours per day, at $0.16,0.34$, or $0.94 \mathrm{mg} / \mathrm{m}^{3}{ }^{77}$. CM-95 aerosols consisted of well-dispersed, straight fibers, ranging from 0.5 to $20 \mu \mathrm{m}$ in length, with an average length of approximately $2.6 \mu \mathrm{m}$ and diameters ranging from 10 to $15 \mathrm{~nm}$. CM-95 consisted of approximately $95 \%$ carbon with approximately $5 \%$ metal impurities. Lung tissue was analyzed for DNA damage using the comet assay after the last exposure or after a recovery period of 1 month. At both timepoints, a significant increase in DNA damage was observed in the lung cells of rats exposed to $0.94 \mathrm{mg} / \mathrm{m}^{3}$. A significant increase in the concentration of hydrogen peroxide was observed in BALF in the $0.94 \mathrm{mg} / \mathrm{m}^{3}$ group after 1 month of recovery. Using dark field imaging, MWCNT were detected in lung tissue when assessed after the last exposure and after 1 month of recovery.

In the second study, male and female Fischer 344/N Slc rats underwent nose-only inhalation exposure to aerosolized CM-100 MWCNT (Hanwha Nanotech, Inc.) for 28 days, 6 hours per day, at $0.17,0.49$, or $0.96 \mathrm{mg} / \mathrm{m}^{378}$. Although CM-95 and CM-100 had nearly identical product information (including length), CM-100 aerosols consisted of well-dispersed, straight fibers that ranged from 0.068 to $1.5 \mu \mathrm{m}$ in length, with an average length of approximately $0.33 \mu \mathrm{m}$. The diameter was not reported. Lung tissue was analyzed for DNA damage using the comet assay after the last exposure or after a recovery period of 3 months. In both male and female rats, significant increases in DNA damage were observed at all concentrations of CM-100 after the last exposure. Small but significant increases in DNA damage were observed in both male and female rats after 3 months of recovery at the higher exposure concentrations. Significant changes in the concentration of hydrogen peroxide were detected in BALF samples from male, but not female, rats. Using dark field imaging, MWCNT were detected in lung tissue when assessed after the last exposure and after 3 months of recovery.

In a third study, male and female Wistar rats were exposed by nose-only inhalation for 5 days per week, 6 hours per day, over a period of 90 days to $0.05,0.25$, or $5 \mathrm{mg} / \mathrm{m}^{3}$ MWCNT 
(Graphistrength $^{\odot}$ C100) $)^{55}$. The Graphistrength ${ }^{\odot}$ aerosols consisted of agglomerates of tangled MWCNTs with a MMAD of less than $3 \mu \mathrm{m}$. Micronuclei were assessed in bone marrow at 24 hours after the last exposure. There was no increase in micronucleated polychromatic erythrocytes (MN-PCEs) in male or female Wistar rats, and exposure to Graphistrength ${ }^{\odot}$ did not affect the percentage of MN-PCEs. Lung, kidney, and liver cells did not show increases in DNA damage (\% tail DNA) when evaluated using a standard comet assay, or when evaluated in a modified comet assay using human 8-oxoguanidine DNA $N$-glycosylase 1 to detect DNA damage that can arise due to oxidative stress. In histological preparations, deposits of MWCNT aggregates were observed in lung tissue, but not in bone marrow, kidney, or liver tissue 24 hours after cessation of exposure. Taken together, these results suggest that MWCNTs are capable of inducing DNA damage in rats when inhaled; however, the genotoxic potential of MWCNTs appears to be dependent on their physicochemical characteristics.

Micronuclei and DNA damage were assessed in human lung carcinoma A549 cells using MWCNTs synthesized in the laboratory and purified to greater than $95 \%$ purity $^{79}$. The MWCNTs were approximately 10 to $20 \mu \mathrm{m}$ in length, similar to L-MWNT-1020. The diameter was not reported. The MWCNTs tended to agglomerate in suspension and were sonicated prior to use. Small but significant increases in micronuclei were observed in A549 cells exposed to $12.5 \mu \mathrm{g} / \mathrm{mL}$ MWCNT for 3 hours, then incubated for 24 hours before harvest and analysis in a cytokinesis block micronucleus assay. Functionalized MWCNT, produced by carboxylation ($\mathrm{COOH}$ ) of the MWCNT, did not show an effect in the assay; however, the functionalization process also reduced the length of the MWCNT-COOH to about 0.2 to $1 \mu \mathrm{m}$. DNA damage was significantly increased in the comet assay in A549 cells exposed to MWCNT for 1 hour, and a modified version of the assay using formamidopyrimidine DNA glycosylase indicated the presence of oxidative damage to DNA. Similar to findings with the cytokinesis block micronucleus assay, MWCNT had a greater effect in the comet assay compared with MWCNT$\mathrm{COOH}$.

\section{Study Rationale}

Nanoscale materials were nominated by the Rice University Center for Biological and Environmental Nanotechnology to NTP for toxicologic testing in 2003 because of intense current and anticipated future research and development focused on nanotechnology. An evaluation of high aspect ratio carbon materials, such as MWCNTs, was included as part of the original nomination. The NTP Nanotechnology Safety Initiative included MWCNTs as a major class of nanoscale materials for investigation. MWCNTs are available for purchase commercially, so there is potential for human exposure at some point in the product life cycle. MWCNTs were selected for study because of concern that they may pose a human health hazard on the basis of the reported induction of granulomas in rodents after pulmonary instillation of SWCNTs, and reported inflammatory responses to some MWCNTs after both intratracheal instillation and subchronic inhalation $2 ; 40 ; 52-54 ; 80 ; 81$.

Although some MWCNTs have been evaluated by subchronic inhalation exposure, the physical aspects and purity of commercially available MWCNTs are diverse. A variety of different carbon nanotubes are commercially available (including single-, double- or multiwalled) that range from less than $1 \mu \mathrm{m}$ to more than $10 \mu \mathrm{m}$ long and that have tube diameters that range from $1 \mathrm{~nm}$ to $100 \mathrm{~nm}$. MWCNT are also available with or without surface functionalizations ( $-\mathrm{OH}$ [hydroxylation] and $-\mathrm{COOH}$ ) and can be in free form or arrayed on solid matrices. There is 
essentially no single representative type of MWCNT that is applicable to all MWCNTs, and it is not known which particular MWCNTs are anticipated to pose the highest exposure or hazard to humans. The primary objective of this study was to evaluate lung burden and clearance of a wellcharacterized long, thin MWCNT following inhalation exposure.

To aid with selecting a test article for study, 24 different MWCNTs were procured and characterized for identity, purity, metals content, physical appearance, and diameter size. These 24 MWCNTs exemplified the various tube lengths and diameters that are commercially available from various vendors. Following extensive chemical and physical evaluations of these 24 MWCNTs $^{82}$ and inhalation feasibility studies of five of these MWCNTs, a 10-20 nm outer diameter and 10-30 $\mu \mathrm{m}$ long MWCNT (Sun Innovations, Inc; item number SN9847) was selected for study on the basis of availability, high purity, and the low amount of residual metal catalyst. This MWCNT represented a "thin" and "long" MWCNT for which few studies had been conducted. Because Chemical Abstracts Service numbers or standard nomenclature rules do not exist for CNT, the name "1020 Long Multiwalled Carbon Nanotubes/L-MWNT-1020" was assigned consistent with the manufacturer's nominal characteristics of 10-30 $\mu \mathrm{m}$ length and 10$20 \mathrm{~nm}$ diameter. Unlike shorter, thicker, and more rigid MWCNTs, such longer, thinner, flexible MWCNTs form tangled agglomerates ("cotton balls"). This agglomerated morphology has been observed in human MWCNT-exposure environments. The chemical/physical characteristics of other CNTs with this designation or description may be different from those of the L-MWNT1020 used in these studies. 


\section{Materials and Methods}

\section{Procurement and Characterization of 1020 Long Multiwalled Carbon Nanotubes}

The test material-1020 Long Multiwalled Carbon Nanotube (L-MWNT-1020) nominal 10$20 \mathrm{~nm}$ outer diameter, 10-30 $\mu \mathrm{m}$ long multiwalled carbon nanotube (MWCNT) — was obtained from Sun Innovations, Inc. (Fremont, CA) in one lot (supplier item number SN9847, supplier lot number $10031301 \mathrm{M}$ ) and was used in the 30-day studies. The study laboratory, Battelle Toxicology Northwest (Richland, WA), assigned the numbers 1 through 12 to the 12 amber glass containers received from the supplier. Identity and purity analyses were conducted by various analytical chemistry laboratories and by the study laboratory (Appendix D). Reports on analyses performed in support of the L-MWNT-1020 studies are on file at the National Institute of Environmental Health Sciences (NIEHS).

Lot $10031301 \mathrm{M}$ of the chemical, a dull black powder, was characterized by Environmental Molecular Sciences Laboratory (EMSL) at Pacific Northwest National Laboratory (PNNL) (Richland, WA) using transmission electron microscopy (TEM), scanning electron microscopy (SEM), Raman spectroscopy, energy dispersive X-ray spectroscopy (EDS), and X-ray photoelectron spectroscopy (XPS). In addition, lot 10031301M was characterized by Elemental Analysis, Inc. (Lexington, KY) using neutron activation analysis (NAA) and by Quantachrome Instruments (Boynton Beach, FL) using helium gas pycnometry (skeletal density), electrophoretic velocimetry (zeta potential), and Brunauer-Emmett-Teller (BET) gas adsorption analysis (surface area). TEM images confirmed test material identity by visualizing agglomerates of MWCNTs and determined an average nanotube diameter of $15.3 \mathrm{~nm}$ (range: 6.1 to $26.7 \mathrm{~nm}$ ) (Figure 2). SEM estimated an average nanotube length of $2.6 \mu \mathrm{m}$ (range: 0.6 to $7.4 \mu \mathrm{m}$ ) (Figure 2). These averages (length of 2,600 nm and width of $15.3 \mathrm{~nm}$ ) yielded an estimated length:width aspect ratio of 170:1 for the nanotubes in lot 10031301M. Raman spectra of lot $10031301 \mathrm{M}$ contained spectral features consistent with those seen in spectra for commercially procured standards of similar graphitic materials, including $\mathrm{G}, \mathrm{G}^{\prime}$, and D bands. A D' band, typical of highly oxidized samples was not observed in the test material. EDS spectra indicated that nickel was present in the test material; subsequent NAA quantitated nickel at $0.52 \%$ by weight. None of the other elements quantitated by NAA (chlorine, cobalt, iron, and copper) were detected above $0.01 \%$. XPS survey scans detected only carbon and oxygen on the surface of the test material. Subsequent high-resolution scans indicated the surface composition of the bulk chemical was approximately 98 atom \% carbon and 2 atom \% oxygen, consistent with literature values $^{83 ; 84}$. BET gas adsorption analysis indicated an average surface area of $175 \mathrm{~m}^{2} / \mathrm{g}$ for lot $10031301 \mathrm{M}$, consistent with values provided by the supplier. Skeletal density, as determined by helium gas pycnometry, was $2.0 \mathrm{~g} / \mathrm{cm}^{3}$. This result was in good agreement with the density reported by the supplier. Measurement of the electrophoretic velocity of L-MWNT-1020 in distilled water yielded a zeta potential of $-30 \mathrm{mV}$, consistent with published values for similar nanotube materials ${ }^{85}$. 

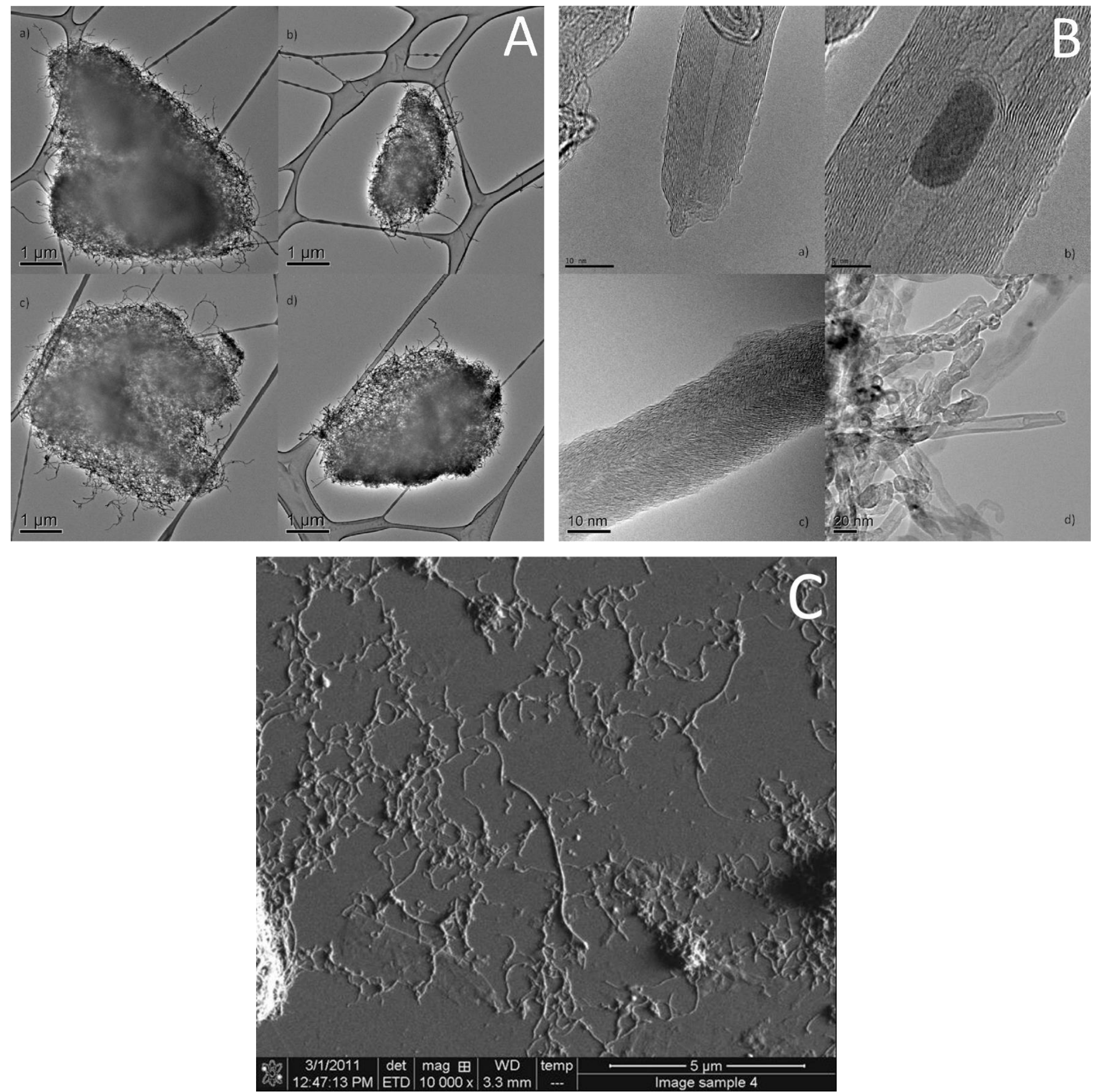

Figure 2. Electron Microscopy Images of 1020 Long Multiwalled Carbon Nanotubes

A) Transmission electron microscopy of bulk L-MWNT-1020; B) higher resolution transmission electron microscopy of bulk LMWNT-1020; C) scanning electron microscopy of dispersed L-MWNT-1020 for length analysis. 
The purity of lot 10031301M was determined by Galbraith Laboratories, Inc. (Knoxville, TN) using elemental analysis and by Netzsch Instruments (Burlington, MA) using thermogravimetric analysis (TGA). Elemental analysis for carbon, hydrogen, nitrogen, and sulfur indicated that lot $10031301 \mathrm{M}$ was $97 \%$ carbon by weight and the other elements assayed were below the quantitation limits of the method used $(<0.5 \%)$. TGA estimated the average percent purity of LMWNT-1020 as approximately $99 \%$ for all containers received. The overall purity of lot $10031301 \mathrm{M}$ was determined to be $97 \%$ or greater.

To ensure stability, the bulk test material was stored in the original 12 amber glass shipping jars at room temperature. Periodic reanalyses of the test material were performed by the study laboratory with TGA and Raman spectroscopy, and no degradation of the bulk test material was detected.

\section{Aerosol Generation and Exposure System}

The aerosol generation system consisted of a linear feed dust metering device to meter LMWNT-1020 from a reservoir into an air stream. Within the metering device, periodic blasts of compressed air suspended small volumes of test material in the air stream for transport to the metering device exhaust tube. A particle attrition chamber was positioned immediately downstream of the metering device exhaust tube for initial particle size reduction of the test material. From the particle attrition chamber, the aerosol was passed through a single jet disperser into the distribution line. The single jet disperser assisted in further dispersion and particle size reduction. Downstream of the disperser jet, primary dilution air (filtered, compressed, humidified air) was added to increase the volumetric flow rate in the aerosol distribution line before the aerosol was passed through a cyclone separator. The cyclone separator removed the larger particles from the distribution system. The linear feed dust metering device, single jet disperser, the primary dilution air assembly and the cyclone separator were housed within a glove box located within the exposure control suite. Secondary dilution air (filtered, compressed, humidified air) was added outside of the glove box within the exposure control suite.

Within the distribution line, aerosol was conveyed from the exposure control suite to the exposure room. In the exposure room, the distribution line split into two lines for delivery to chambers situated on both sides of the exposure room. One branch transported aerosol to the 0.3 , 1 , and $3 \mathrm{mg} / \mathrm{m}^{3}$ chambers, and the second branch transported aerosol to the 0.1 and $10 \mathrm{mg} / \mathrm{m}^{3}$ chambers. During exposures, the air flow through the distribution lines was controlled using house vacuum regulated by a filter-protected flow meter. A second distribution line flow control system was available during off-exposure periods. This system consisted of a vacuum transducer pump of higher flow capacity positioned in parallel with the flow meter control assembly that became operational only during critical shut-down periods. High-efficiency particulate air (HEPA) filters were placed before the vacuum supply and transducer pump at the end of each delivery line to remove aerosol from the airstream prior to exhausting from the room. At each exposure chamber location, aerosol was directed from the distribution line by a sampling tube into the chamber conditioned air supply for mixing prior to delivery to the chamber. The flow through the sampling tube was induced by a stainless steel ejector pump designed and fabricated at Battelle. The flow rate and configuration of each ejector pump and sampling tube combination were chosen to optimize the efficiency of the delivery system and achieve the desired exposure concentration. 
The study laboratory designed the inhalation exposure chamber (Lab Products, Inc., Seaford, DE) so that uniform aerosol concentrations could be maintained throughout the chamber with the catch pans in place. The total active mixing volume of each chamber was $1.7 \mathrm{~m}^{3}$. At each exposure concentration, the chambers housed both rats and mice from the concurrent studies.

\section{Aerosol Concentration Monitoring}

Summaries of the chamber aerosol concentrations are given in Table D-1. The concentrations of L-MWNT-1020 in the exposure chambers and room air were monitored using three real-time aerosol monitors (RAMs). The monitors were connected to the chambers through sample lines and a multiplexing valve designed to minimize aerosol losses caused by settling or impaction. Each RAM was multiplexed to the exposure chambers and/or the $0 \mathrm{mg} / \mathrm{m}^{3}$ chamber or the exposure room and a HEPA-filtered air blank. The output voltage of each RAM was recorded by the Battelle Exposure Data Acquisition and Control software system and converted to $\mathrm{mg} / \mathrm{m}^{3}$ exposure concentration by the application of a calibration curve. Each measured concentration was compared to limit values for the locations monitored by each RAM and, if a measured concentration exceeded its control limits, the Battelle Exposure Data Acquisition and Control (BEDAC) system triggered an audible alert or, in extreme cases, terminated the exposure.

Each RAM was calibrated by constructing a response curve using the measured RAM voltages (corrected for zero offset voltage measured in a HEPA-filtered airstream) and L-MWNT-1020 concentrations determined by gravimetric analysis of filter samples obtained from the exposure chambers. Duplicate exposure chamber atmosphere samples were collected each day on Teflon ${ }^{\circledR}$ coated, glass fiber filters. Validation studies demonstrated that gravimetric and chemical-specific measurements of chamber concentrations were comparable. An ultraviolet visible spectrophotometric assay was used for chemical-specific analysis of L-MWNT-1020. This assay used an off-line liquid chromatograph to measure changes in absorbance (at $538 \mathrm{~nm}$ ) of an aqueous solution that contained a dye that had an affinity for filter-trapped L-MWNT-1020. The off-line chromatograph was calibrated using gravimetrically prepared calibration standards of the test article. These methods were demonstrated by the study laboratory to have adequate precision, accuracy, linear working range, day-to-day respectability, and detection limits for the L-MWNT-1020 concentrations in the exposure chambers.

\section{Chamber Atmosphere Characterization}

Aerosol particle size distribution was determined once prior to and once during the 30-day studies by collecting aerosol samples from each exposure chamber using a Mercer-style cascade impactor. L-MWNT-1020 was collected (for stages one through seven) on $37 \mathrm{~mm}$ stainless steel slides lightly coated with silicone or (for stage eight) $47 \mathrm{~mm}$ Teflon-coated glass fiber filters to establish the mass median aerodynamic diameter (MMAD) of the aerosol particles. The impactor samples were analyzed gravimetrically to determine the amount of L-MWNT-1020 collected on each stage. The relative mass of L-MWNT-1020 collected on each impactor stage was analyzed by the NEWCAS impactor analysis program developed at the study laboratory based on probit analysis ${ }^{86}$. All MMAD values were below the $3.0 \mu \mathrm{m}$ upper limit criterion required by the design of the studies.

For each exposure chamber, the count median diameter (CMD) for the aerosol and the number of particles per unit volume were determined once before and once during the 30-day studies using 
an electrical low pressure impactor (ELPI). The ELPI counted the number of particles in 12 size bins within a size range of 0.03 to $10 \mu \mathrm{m}$. The CMD and particle number concentration were analyzed using the ELPI VI 4.0 Data Analysis Software provided by the manufacturer. CMDs for the aerosol ranged from 92 to $99 \mathrm{~nm}$ with the number of particles varying from $3.5 \times 10^{4}$ to $1.1 \times 10^{6}$ particles $/ \mathrm{cm}^{3}$.

Buildup and decay rates for chamber aerosol concentrations were determined at two ports for each chamber with and without animals present in the chambers. At a chamber airflow rate of $15 \mathrm{ft}^{3} /$ minute, the theoretical value for the time to achieve $90 \%$ of the target concentration after the beginning of aerosol generation ( $\left.\mathrm{T}_{90}\right)$ was approximately 9.2 minutes and the time for the chamber concentration to decay to $10 \%$ of the target concentration after aerosol generation was terminated $\left(\mathrm{T}_{10}\right)$ was approximately 12 minutes. A $\mathrm{T}_{90}$ value of 12 minutes was selected for the studies.

The uniformity of aerosol concentration in the inhalation exposure chambers without animals was evaluated before the studies began; in addition, concentration uniformity with animals present in the chamber was measured once during the 30-day studies. Concentrations were measured at all 12 sample ports; one in front and one in back for each of six possible animal cage unit positions per chamber. Chamber concentration uniformity was maintained throughout the studies.

The persistence of L-MWNT-1020 in the chambers after aerosol delivery ended was determined by monitoring the concentration overnight in the $10 \mathrm{mg} / \mathrm{m}^{3}$ chamber in the 30-day studies with and without animals present in the chamber. The concentration decreased to $1 \%$ of the target concentration within 14 minutes with animals present and within 18 minutes without animals.

Stability studies of L-MWNT-1020 in the generation and delivery system were performed before and during the studies by EMSL/PNNL (TEM, Raman spectroscopy, and XPS), Quantachrome Instruments (BET surface area), Netzsch Instruments (TGA), and the study laboratory (elemental analysis by inductively coupled plasma/atomic emission spectroscopy [ICP/AES]). TEM imagery indicated that the morphology of the test material collected from the exposure aerosol was qualitatively similar to that observed in the bulk material (Figure 3). BET surface area analysis determined that the surface area of the test material in the exposure system was generally comparable to the results of the initial characterization tests of lot 10031301M. Raman spectra of L-MWNT-1020 collected from the exposure system were consistent with Raman spectra of the bulk chemical as determined in the initial test chemical characterization. XPS surface scans of the exposure system aerosol samples indicated that the surface of L-MWNT1020 included carbon and oxygen and that substantial oxidation of the test chemical did not occur during generation of aerosolized exposure atmospheres. No impurities or degradation products were detected by TGA in any of the exposure atmosphere aerosol samples. ICP/AES results were consistent with elemental analyses of the bulk test material in the initial characterization of the test chemical. Taken together, these results demonstrated that the composition of L-MWNT-1020 was stable in the exposure system and contamination from metal materials in the exposure system did not occur. 


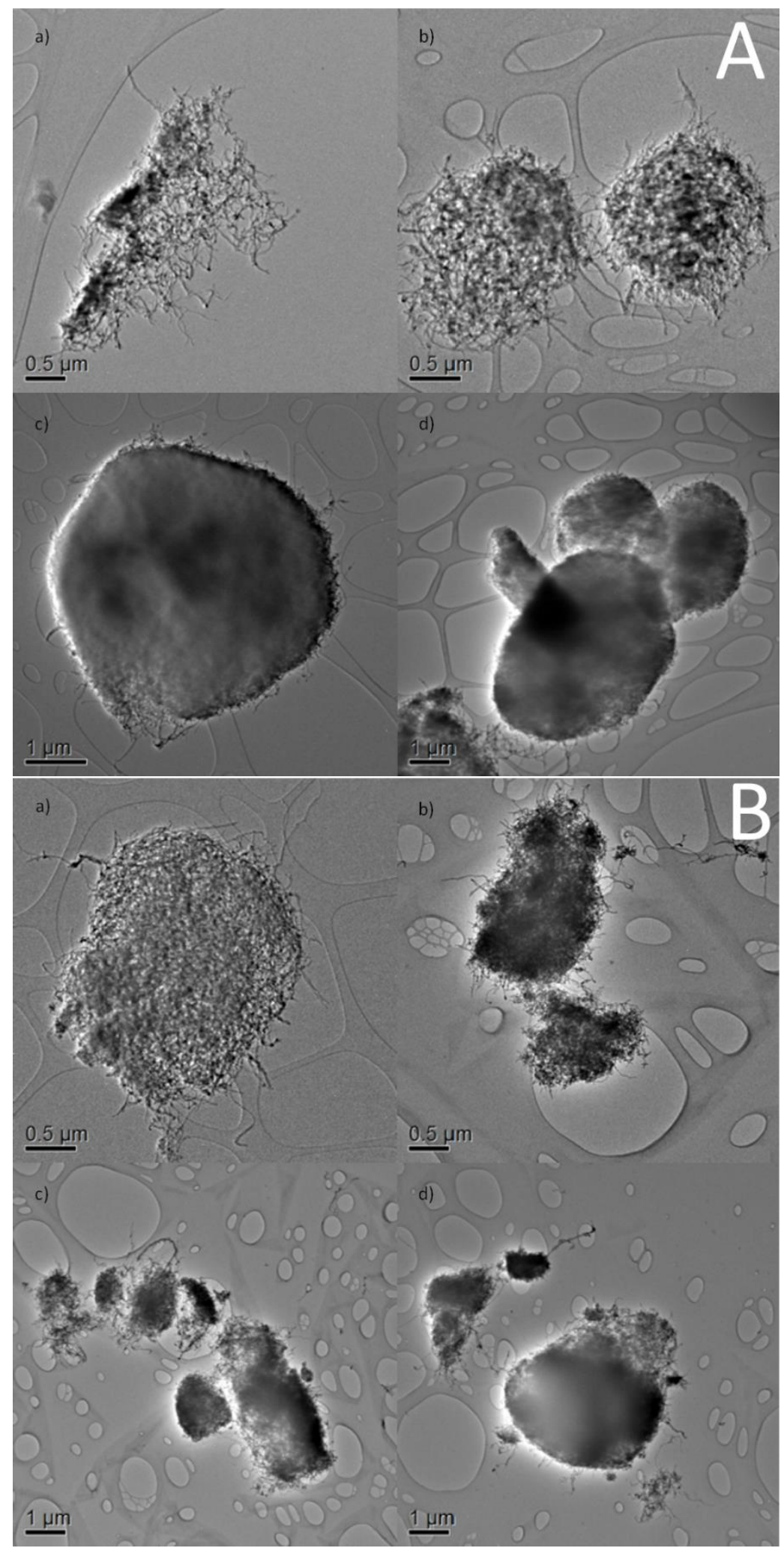

Figure 3. Representative Transmission Electron Microscopy from 1020 Long Multiwalled Carbon Nanotubes Chamber Samples

A) $0.1 \mathrm{mg} / \mathrm{m}^{3}$ chamber sample; B) $10 \mathrm{mg} / \mathrm{m}^{3}$ chamber sample. 


\section{Animal Source}

Male and female Sprague Dawley (Hsd:Sprague Dawley ${ }^{\circledR} \mathrm{SD}^{\circledR}$ ) rats were obtained from Envigo (formerly Harlan Laboratories, Livermore, CA), and male and female B6C3F1/N mice were obtained from the National Toxicology Program (NTP) colony maintained at Taconic Biosciences, Inc. (Germantown, NY), for the 30-day studies.

\section{Animal Welfare}

Animal care and use are in accordance with the Public Health Service Policy on Humane Care and Use of Animals. All animal studies were conducted in an animal facility accredited by the AAALAC International. Studies were approved by the Battelle Toxicology Northwest Animal Care and Use Committee and conducted in accordance with all relevant NIH and NTP animal care and use policies and applicable federal, state, and local regulations and guidelines.

On receipt, the rats and mice were 4 to 5 weeks old. Animals were quarantined for 12 days and were 5 to 6 weeks old on the first day of the studies. Before the studies began, 5 male and 5 female rats and mice were randomly selected for parasite evaluation (pinworms, Syphacia obvalata and S. muris) and gross observation for evidence of disease. The health of the animals was monitored during the studies according to the protocols of the NTP Sentinel Animal Program (Appendix F). All test results were negative.

\section{Lung Burden Studies}

For lung burden determination, groups of 25 male and 25 female rats and mice were exposed to L-MWNT-1020 by whole-body inhalation at concentrations of $0,0.1,0.3,1,3$, or $10 \mathrm{mg} / \mathrm{m}^{3}$, 6 hours plus $\mathrm{T}_{90}(12$ minutes) per day, 5 days per week for 30 (males) or 31 (females) days. These exposure concentrations were selected based on 90-day studies in the literature that reported moderate toxicologic effects following inhalation exposure to up to $6 \mathrm{mg} / \mathrm{m}^{3}$ MWCNT $^{49 ; 52}$. Animals were weighed and lungs were collected from 10 male and 10 female rats and mice on the last exposure day and from 5 male and 5 female rats and mice after 14, 42, and 126 days of recovery. Right and left lung lobes were weighed separately and stored at $-70^{\circ} \mathrm{C}$ until analysis for nickel concentration. Homogenized samples of lung tissue (left and right lobes combined; $2 \mathrm{~g}$ for rats and $0.2 \mathrm{~g}$ for mice) were weighed into microwave digestion vessels along with $0.2 \mathrm{~mL}$ of a $1 \mathrm{mg}$ yttrium $/ \mathrm{mL}$ internal standard and $10 \mathrm{~mL}$ of $70 \%$ nitric acid. After a $15-$ minute predigestion, the samples were digested in a microwave sample preparation system (CEM Corp., Matthews, NC). Samples were diluted to an appropriate volume with deionized water before analysis using inductively coupled plasma-mass spectroscopy (Agilent 7500ce ICP/MS, Agilent Technologies, Palo Alto, CA).

As has been used in other studies ${ }^{53 ; 54}$, monitoring of the residual metal catalyst was used as a surrogate for measurement of the MWCNT burden. Nickel content, which makes up $0.52 \%$ of LMWNT-1020, was used to determine the amount of L-MWNT-1020 in lung samples. Studies conducted during prestart activities confirmed that nickel remained bound to the L-MWNT-1020 in the exposure atmosphere. These studies were conducted to determine if nickel would leach from the L-MWNT-1020. L-MWNT-1020 samples were prepared in simulated lung fluid (Gamble's solution), incubated at $37^{\circ} \mathrm{C}$, and removed from the incubator at $0,2,7,15$, and 29 days following preparation. At each timepoint, the bottles were shaken vigorously, 
centrifuged, and filtered. Triplicate samples were analyzed for nickel content by ICP/MS. No more than about $1 \%$ of nickel present in the L-MWNT-1020 leached out over a period up to 29 days in synthetic lung fluid. This amount is within the margin of error for ICP/AES

measurements. In addition to the leaching experiments, the long half-life of nickel in the lungs of exposed animals indicated that it was tightly bound; a much shorter half-life would be expected if nickel was mobilized from the nanotubes.

Lung nickel concentration ( $\mu \mathrm{g} \mathrm{Ni/g} \mathrm{lung)} \mathrm{was} \mathrm{calculated} \mathrm{by} \mathrm{multiplying} \mathrm{the} \mathrm{internal} \mathrm{standard}$ corrected nickel concentration ( $\mu \mathrm{g} \mathrm{Ni} / \mathrm{L}$ ) measured in the digest by the nominal dilution volume (L) and dividing by the sample weight $(\mathrm{g})$. Mean recoveries of nickel from spiked rat lung $(1.0 \pm 0.04 \mathrm{~g})$ ranged from $16 \%$ to $32 \%$ with relative standard deviations (RSDs) ranging from $13 \%$ to $63 \%$. To evaluate the effects of interference arising from the lung matrix, a spiked rat standard using two times the mass of lung tissue $(\sim 2 \mathrm{~g})$ was assayed. The spiked rat lung had a mean recovery of $34 \%$ with an RSD of $16 \%$. Mean recoveries from spiked mouse lung $(0.12 \pm 0.04 \mathrm{~g})$ ranged from $25 \%$ to $82 \%$ with RSDs ranging from $6 \%$ to $40 \%$. The mean recovery from the spiked mouse standard—using two times the mass of lung tissue $(\sim 0.24 \mathrm{~g})$ to evaluate the effects of interference arising from the lung matrix-was $36 \%$ with an RSD of $3 \%$.

Total lung burden ( $\mu \mathrm{g} \mathrm{Ni/lung)} \mathrm{was} \mathrm{calculated} \mathrm{by} \mathrm{multiplying} \mathrm{the} \mathrm{measured} \mathrm{nickel} \mathrm{concentration}$ ( $\mu \mathrm{g} \mathrm{Ni} / \mathrm{g}$ ) by the total sample weight at collection (g). Total lung L-MWNT-1020 burden ( $\mu \mathrm{g}$ LMWNT-1020/lung) was calculated by dividing the total lung burden ( $\mu$ g Ni/lung) by the fraction of nickel in L-MWNT-1020 (0.52\%). Total L-MWNT-1020 burdens normalized to exposure concentration ( $\mu \mathrm{g}$ L-MWNT-1020/lung per mg L-MWNT-1020/m³) were calculated by dividing the total lung L-MWNT-1020 burden by the corresponding target exposure concentration $\left(\mathrm{mg} / \mathrm{m}^{3}\right)$.

Lung clearance rates for L-MWNT-1020 were calculated using Equation (1):

Equation (1): $\mathrm{A}(\mathrm{t})=\mathrm{A}_{0}\left(\mathrm{e}^{-\mathrm{kt}}\right)$

where $\mathrm{A}(\mathrm{t})$ is the lung burden ( $\mu \mathrm{g}$ L-MWNT-1020/lung) at time $\mathrm{t}$ (days postexposure), $A_{0}$ is the lung burden at $\mathrm{t}=0$ days postexposure (day 30 [males] or 31 [females]), and $\mathrm{k}$ is the lung clearance rate constant (fraction cleared per day). Using this model, the data were plotted on a semilog scale and Equation (1) fitted to the plot using a least-squares error minimization curve fitting method with weighting (lung burden) ${ }^{-1}$. This fit produced estimates of $\mathrm{A}_{0}$ and $\mathrm{k}$ as well as standard deviations for each estimate. Using this model, a semilog plot of $A(t)$ versus time produces a straight line with $\mathrm{y}$-intercept $\mathrm{A}_{0}$ and slope $-\mathrm{k}$.

Lung clearance half-lives in days $\left(\mathrm{t}_{1 / 2}\right)$ were calculated from Equation (2):

Equation (2): $\mathrm{t}_{1} / 2=\ln 2 / \mathrm{k}$

Standard deviations for calculated half-lives were estimated using the uncertainty in $\mathrm{k}$ determined by the model fit.

\section{Core Studies}

For the core studies, groups of 10 male and 10 female rats and mice were exposed to the same concentrations of L-MWNT-1020 for the same length of time as in the lung burden study. Feed and water were available ad libitum, except feed was withheld during exposure periods. Animals 
were randomized into groups and assigned identification numbers based on body weights. Rats and mice were housed individually in stainless steel wire-bottom cages within each exposure chamber. Cage units were rotated among levels in each chamber during weekly chamber changeout. Rotation consisted of moving each cage unit to the next lower occupied level and moving the bottom unit to the highest occupied level of the chamber. Body weights were recorded on day 1 , and clinical observations and body weights were recorded on day 9 , weekly thereafter, and at the end of the studies. Necropsies were performed on all core study rats and mice. Details of the study design, animal maintenance, and tissues and organs examined are summarized in Table 1. Organs weighed at necropsy included the liver, thymus, right kidney, right testis, heart, and lungs. For histopathology, protocol required tissues included nasal cavity, trachea, larynx, pharynx, lymph nodes (mediastinal and bronchial), lungs (with mainstem bronchi), and gross lesions (as applicable). Tissues were fixed in 10\% neutral buffered formalin. Testes, vaginal tunics, and epididymides were fixed in modified Davidson's and then transferred to $10 \%$ neutral buffered formalin. Tissues were trimmed, processed, embedded in paraffin, sectioned, and stained with hematoxylin and eosin (H\&E). Histopathologic evaluation was limited to gross lesions and the following tissues: larynx, lungs and mainstem bronchi, lymph nodes (bronchial and mediastinal), nose, pharynx, and trachea. Microscopic examinations of these tissues were performed on control animals and those exposed to $10 \mathrm{mg} / \mathrm{m}^{3}$. Exposure-related lesions were examined to a no-effect level. Gross lesions from all exposure groups were also examined microscopically.

After a review of the laboratory reports and selected histopathology slides by a quality assessment (QA) pathologist, the findings and reviewed slides were submitted to an NTP Pathology Peer Review (PPR) coordinator for a second independent review. Any inconsistencies in the diagnoses made by the study laboratory and QA pathologists were resolved by the NTP PPR process. Final diagnoses for reviewed lesions represent a consensus of the PPR or a consensus between the study laboratory pathologist, NTP pathologist, QA pathologist(s), and the PPR coordinator. Details of these review procedures have been described, in part, by Maronpot and Boorman ${ }^{87}$ and Boorman et al. ${ }^{88}$. 
Table 1. Experimental Design and Materials and Methods in the 30-day Inhalation Studies of 1020 Long Multiwalled Carbon Nanotubes

\section{Thirty-day Studies}

\section{Study Laboratory}

Battelle Toxicology Northwest (Richland, WA)

\section{Strain and Species}

Sprague Dawley (Hsd:Sprague Dawley ${ }^{\circledR} \mathrm{SD}^{\circledR}$ ) rats

B6C3F1/N mice

\section{Animal Source}

Rats: Envigo (formerly Harlan Laboratories, Inc., Livermore, CA)

Mice: Taconic Biosciences, Inc. (Germantown, NY)

\section{Time Held Before Studies}

12 days

Average Age When Studies Began

Rats: 6 weeks

Mice: 5 to 6 weeks

\section{Date of First Exposure}

Rats: May 23, 2011

Mice: May 30, 2011

\section{Duration of Exposure}

6 hours plus T90 (12 minutes) per day, 5 days per week, for 30 (males) or 31 (females) days

\section{Date of Last Exposure}

Rats: June 21 (males) or June 22 (females), 2011

Mice: June 28 (males) or June 29 (females), 2011

\section{Necropsy Dates}

Rats: June 22 (males) or June 23 (females), 2011

Mice: June 29 (males) or June 30 (females), 2011

\section{Average Age at Necropsy}

10 to 11 weeks

\section{Size of Study Groups}

Lung burden study: 25 males and 25 females

Core study: 10 males and 10 females

\section{Method of Distribution}

Animals were distributed randomly into groups of approximately equal initial mean body weights.

Animals per Cage

1

Method of Animal Identification

Tail tattoo 


\section{Thirty-day Studies}

\section{Diet}

Irradiated NTP-2000 open formula pelleted diet (Zeigler Brothers, Inc., Gardners, PA), available ad libitum except during exposure periods, changed daily

\section{Water}

Tap water (Richland municipal supply) via automatic watering system (Edstrom Industries, Waterford, WI), available ad libitum

\section{Cages}

Stainless steel wire bottom (Lab Products, Inc., Seaford, DE), changed and rotated weekly

\section{Cageboard}

Untreated paper cage pan liner (Techboard Ultra, Shepherd Specialty Papers, Watertown, TN), changed daily

\section{Chamber Air Supply Filters}

Single HEPA (open stock), charcoal (RSE, Inc., New Baltimore, MI), Purafil (Environmental Systems, Lynnwood, WA), all new at study start

\section{Chambers}

Stainless steel excreta pan at each of six levels (Lab Products, Inc., Seaford, DE), chamber changed weekly, excreta pan changed daily

\section{Chamber Environment}

Temperature: $72^{\circ} \mathrm{F} \pm 3^{\circ} \mathrm{F}$

Relative humidity: $55 \% \pm 15 \%$

Room fluorescent light: 12 hours/day

Chamber air changes: at least 15/hour

\section{Exposure Concentrations}

$0,0.1,0.3,1,3$ or $10 \mathrm{mg} / \mathrm{m}^{3}$

\section{Type and Frequency of Observation}

Observed twice daily; core study animals were weighed initially, on day 9 , then weekly and at the end of the studies; clinical observations were recorded on day 9, then weekly and at the end of the studies.

\section{Method of Euthanasia}

Carbon dioxide inhalation

\section{Lung Burden Studies}

Postexposure on the last exposure day (10 male and 10 female rats and mice) and after 14, 42, and 126 days of recovery ( 5 male and 5 female rats and mice per timepoint) lung burden animals were weighed and lungs were collected, weighed, and analyzed for nickel concentration, which was used to calculate L-MWNT-1020 concentration.

\section{Necropsy}

Necropsies were performed on all core study animals. Organs weighed were heart, right kidney, liver, lung, right testis, and thymus.

\section{Histopathology}

Histopathology was performed on all core study rats and mice. Histopathologic evaluation was limited to gross lesions and the following tissues: larynx, lungs and mainstem bronchi, lymph nodes (bronchial and mediastinal), nose, pharynx, and trachea. 


\section{Statistical Methods}

\section{Calculation and Analysis of Lesion Incidences}

The incidences of lesions are presented in Appendix A as the numbers of animals bearing such lesions at a specific anatomic site and the numbers of animals with that site examined microscopically. The Fisher exact test ${ }^{89}$, a procedure based on the overall proportion of affected animals, was used to determine significance.

\section{Analysis of Continuous Variables}

Two approaches were employed to assess the significance of pairwise comparisons between dosed and control groups in the analysis of continuous variables. Organ and body weight data, which historically have approximately normal distributions, were analyzed with the parametric multiple comparison procedures of Dunnett ${ }^{90}$ and Williams ${ }^{91 ; 92}$. Lung burden data, which have typically skewed distributions, were analyzed using the nonparametric multiple comparison methods of Shirley ${ }^{93}$ (as modified by Williams ${ }^{94}$ ) and Dunn ${ }^{95}$. Jonckheere's test ${ }^{96}$ was used to assess the significance of the dose-related trends and to determine whether a trend-sensitive test (Williams' or Shirley's test) was more appropriate for pairwise comparisons than a test that does not assume a monotonic dose-related trend (Dunnett's or Dunn's test). Prior to statistical analysis, extreme values identified by the outlier test of Dixon and Massey ${ }^{97}$ were examined by NTP personnel, and implausible values were eliminated from the analysis.

\section{Quality Assurance Methods}

The 30-day studies were conducted in compliance with Food and Drug Administration Good Laboratory Practice Regulations ${ }^{98}$. In addition, as records from the 30-day studies were submitted to the NTP Archives, these studies were audited retrospectively by an independent QA contractor. Separate audits covered completeness and accuracy of the pathology data, pathology specimens, final pathology tables, and a draft of this NTP Toxicity Report. Audit procedures and findings are presented in the reports and are on file at NIEHS. The audit findings were reviewed and assessed by NTP staff, and all comments were resolved or otherwise addressed during the preparation of this Toxicity Report. 


\section{Results}

\section{Lung Burden Study in Rats}

Summaries of body weights, lung weights, and lung burdens for male and female rats are presented in Table 2 and Table C-1. Lung weights in males were not significantly different from those in the chamber controls except in the 3 and $10 \mathrm{mg} / \mathrm{m}^{3}$ groups. In the male 3 and $10 \mathrm{mg} / \mathrm{m}^{3}$ dose groups, lung weights were significantly greater than those in the chamber control animals at 0 and 14 days postexposure. Likewise, lung weights in females were indistinguishable from chamber controls except in the 3 and $10 \mathrm{mg} / \mathrm{m}^{3}$ dose groups. In the female 3 and $10 \mathrm{mg} / \mathrm{m}^{3}$ dose groups, lung weights were significantly greater than those in the chamber control animals at 0 and 42 days postexposure. Increases in lung weights in the top two exposure concentration groups were resolved by the end of the postexposure period (126 days postexposure).

Normalized lung burdens generally decreased with increasing postexposure time but were quite variable across the exposed groups of males and females (Table 2). Although normalized lung burdens in groups exposed to higher concentrations generally decreased less with postexposure time compared to groups exposed to lower concentrations, no consistent trends toward increased or decreased normalized lung burdens were observed. This was likely due to high variability in the sample mean estimates, which were calculated from small sample sizes. The typical sample size for lung burden studies range from 5 to 10 animals per sex per exposure group.

\section{Lung Clearance Kinetics}

Semilog plots of male and female rat lung burden versus days postexposure are presented in Figure C-1, Figure C-2, Figure C-3, Figure C-4, and Figure C-5. These plots also show the fit of the lung clearance model to the data; results of lung burden modeling are presented in Table 3 .

As shown in Figure C-1, Figure C-2, Figure C-3, Figure C-4, and Figure C-5, although there was considerable variability in the data, the model fits the data adequately. These figures also show that the slope of the line from the model fit decreases progressively as exposure concentrations increase, indicating significant decreases in the clearance rate constant with increasing exposure concentration.

\section{Lung Burden Modeling}

Comparison of the model-estimated values of initial lung burdens in Table 3 with the lung burdens measured at the end of exposure (postexposure day 0; Table 2) indicates that the modelextrapolated burdens compare well with the actual lung burdens at that timepoint. 
Table 2. Postexposure Lung Weights, Nickel Concentrations and Burdens, and 1020 Long Multiwalled Carbon Nanotube Burdens for Rats in the 30-day Inhalation Study of 1020 Long Multiwalled Carbon Nanotubes

\begin{tabular}{|c|c|c|c|c|c|c|}
\hline & $\begin{array}{c}\text { Chamber } \\
\text { Control }\end{array}$ & $0.1 \mathrm{mg} / \mathrm{m}^{3}$ & $0.3 \mathrm{mg} / \mathrm{m}^{3}$ & $1 \mathrm{mg} / \mathrm{m}^{3}$ & $3 \mathrm{mg} / \mathrm{m}^{3}$ & $10 \mathrm{mg} / \mathrm{m}^{3}$ \\
\hline \multicolumn{7}{|l|}{$\mathbf{n}$} \\
\hline Day 0 & 10 & 10 & 10 & 10 & 10 & 10 \\
\hline Day 14 & 5 & 5 & 5 & 5 & 5 & 5 \\
\hline Day 42 & 5 & 5 & 5 & 5 & 5 & 5 \\
\hline Day 126 & 5 & 5 & 5 & 5 & 5 & 5 \\
\hline
\end{tabular}

\section{Male}

Lung Weight (g)

$\begin{array}{llllllc}\text { Day 0 } & 1.426 \pm 0.047 & 1.511 \pm 0.064 & 1.595 \pm 0.105 & 1.599 \pm 0.112 & 1.770 \pm 0.054 * * & 1.782 \pm 0.037 * * \\ \text { Day 14 } & 1.675 \pm 0.214 & 1.807 \pm 0.158 & 1.825 \pm 0.036 & 1.752 \pm 0.078 & 2.106 \pm 0.075^{*} & 2.286 \pm 0.139 * * \\ \text { Day 42 } & 2.029 \pm 0.180 & 1.772 \pm 0.101 & 1.749 \pm 0.076 & 2.123 \pm 0.135 & 2.135 \pm 0.147 & 1.973 \pm 0.112 \\ \text { Day 126 } & 1.996 \pm 0.178 & 1.885 \pm 0.056 & 2.009 \pm 0.199 & 2.153 \pm 0.208 & 2.191 \pm 0.258 & 2.175 \pm 0.068\end{array}$

Sample Concentration $(\mu \mathrm{g} \mathrm{Ni} / \mathrm{g})$

$\begin{array}{lllllll}\text { Day 0 } & 0.001 \pm 0.000 & 0.028 \pm 0.001 * * & 0.095 \pm 0.015 * * & 0.327 \pm 0.019 * * & 0.818 \pm 0.030^{* *} & 2.060 \pm 0.102 * * \\ \text { Day 14 } & 0.001 \pm 0.000 & 0.017 \pm 0.001 * * & 0.052 \pm 0.003^{* *} & 0.313 \pm 0.019 * * & 0.721 \pm 0.047 * * & 1.803 \pm 0.082 * * b \\ \text { Day 42 } & 0.001 \pm 0.000 & 0.012 \pm 0.002 * * & 0.041 \pm 0.004 * * & 0.204 \pm 0.020 * * & 0.576 \pm 0.060 * * & 1.657 \pm 0.057 * * \\ \text { Day 126 } & 0.001 \pm 0.000 & 0.005 \pm 0.001 * * & 0.020 \pm 0.005^{* *} & 0.097 \pm 0.016 * * & 0.428 \pm 0.062 * * & 1.426 \pm 0.084 * *\end{array}$ Total Lung Burden ( $\mu \mathrm{g} \mathrm{Ni/lung)}$

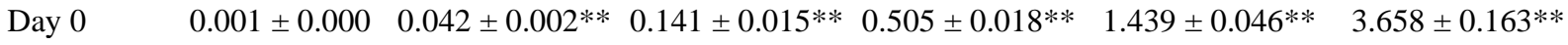

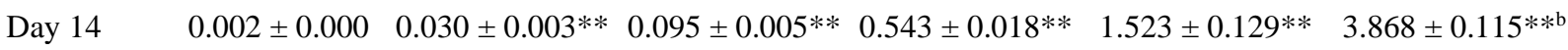

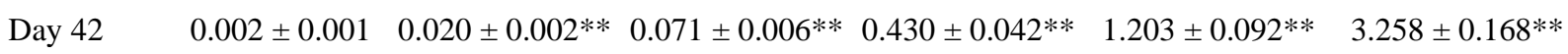

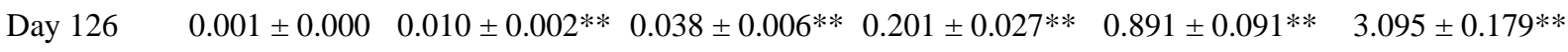

Total Lung Burden ( $\mu \mathrm{g}$ L-MWNT-1020/lung)
Day 0
$0.192 \pm 0.006 \quad 8.052 \pm 0.405 * * 27.10 \pm 2.802 * * 97.19 \pm 3.421 * *$
$276.8 \pm 8.902 * *$
$703.5 \pm 31.28 * *$
Day 14
$0.323 \pm 0.096 \quad 5.832 \pm 0.641^{* *} 18.2$
$8.24 \pm 1.036^{* *} 104.3 \pm 3.377 * *$
$292.9 \pm 24.80 * *$
$743.9 \pm 22.07^{* * \mathrm{~b}}$
Day 42
$0.444 \pm 0.180 \quad 3.858$
$.858 \pm 0.410^{* *} 13.72 \pm 1.248^{* *} 82.64 \pm 8.158^{* *}$
$231.4 \pm 17.66^{* *}$
$626.5 \pm 32.40^{* *}$
Day 126
$0.269 \pm 0.0241 .907 \pm 0.331 * * 7.262 \pm 1.074 * * 38.74 \pm 5.273 * *$
$171.3 \pm 17.49^{* *}$
$595.3 \pm 34.34 * *$

Normalized Lung Burden ( $\mu$ g L-MWNT-1020/lung per mg $/ \mathrm{m}^{3}$ )

\begin{tabular}{lllllll} 
Day 0 & $-^{\mathrm{a}}$ & $80.52 \pm 4.05$ & $90.33 \pm 9.34$ & $97.19 \pm 3.42$ & $92.27 \pm 2.97$ & $70.35 \pm 3.13$ \\
Day 14 & - & $58.32 \pm 6.41$ & $60.80 \pm 3.45$ & $104.35 \pm 3.38$ & $97.62 \pm 8.27$ & $74.39 \pm 2.21^{\mathrm{b}}$ \\
Day 42 & - & $38.58 \pm 4.10$ & $45.73 \pm 4.16$ & $82.64 \pm 8.16$ & $77.13 \pm 5.89$ & $62.65 \pm 3.24$ \\
Day 126 & - & $19.07 \pm 3.31$ & $24.21 \pm 3.58$ & $38.74 \pm 5.27$ & $57.09 \pm 5.83$ & $59.53 \pm 3.43$ \\
\hline
\end{tabular}




\begin{tabular}{cccccc}
\hline $\begin{array}{c}\text { Chamber } \\
\text { Control }\end{array}$ & $0.1 \mathrm{mg} / \mathrm{m}^{3}$ & $0.3 \mathrm{mg} / \mathrm{m}^{3}$ & $1 \mathrm{mg} / \mathrm{m}^{3}$ & $3 \mathrm{mg} / \mathrm{m}^{3}$ & $10 \mathrm{mg} / \mathrm{m}^{3}$ \\
\hline
\end{tabular}

\section{Female}

Lung Weight (g)

$\begin{array}{llllllc}\text { Day 0 } & 1.230 \pm 0.033 & 1.222 \pm 0.050 & 1.200 \pm 0.025 & 1.212 \pm 0.035 & 1.378 \pm 0.041 * * & 1.477 \pm 0.040 * * \\ \text { Day 14 } & 1.452 \pm 0.070 & 1.298 \pm 0.107 & 1.330 \pm 0.080 & 1.421 \pm 0.088 & 1.428 \pm 0.066 & 1.571 \pm 0.041 \\ \text { Day 42 } & 1.359 \pm 0.062 & 1.324 \pm 0.056 & 1.295 \pm 0.034 & 1.371 \pm 0.037 & 1.574 \pm 0.087 * & 1.509 \pm 0.037 * \\ \text { Day 126 } & 1.404 \pm 0.058 & 1.457 \pm 0.071 & 1.468 \pm 0.082 & 1.397 \pm 0.088 & 1.665 \pm 0.152 & 1.715 \pm 0.053\end{array}$

Sample Concentration $(\mu \mathrm{g} \mathrm{Ni} / \mathrm{g})$

$\begin{array}{lllllll}\text { Day } 0 & 0.002 \pm 0.000 & 0.026 \pm 0.001 * * & 0.101 \pm 0.009 * * & 0.374 \pm 0.013 * * & 0.885 \pm 0.028 * * & 2.351 \pm 0.079 * * \\ \text { Day } 14 & 0.004 \pm 0.002 & 0.022 \pm 0.002 * * & 0.065 \pm 0.007 * * & 0.285 \pm 0.030^{* *} & 0.893 \pm 0.048 * * & 2.117 \pm 0.069 * * \\ \text { Day 42 } & 0.002 \pm 0.001 & 0.015 \pm 0.003 * * & 0.048 \pm 0.005 * * & 0.268 \pm 0.022 * * & 0.827 \pm 0.101 * * & 2.147 \pm 0.065 * * \\ \text { Day 126 } & 0.001 \pm 0.000 & 0.005 \pm 0.000 * * & 0.014 \pm 0.002 * * & 0.105 \pm 0.015 * * & 0.489 \pm 0.083 * * & 1.776 \pm 0.137 * *\end{array}$ Total Lung Burden ( $\mu \mathrm{g} \mathrm{Ni/lung)}$

$\begin{array}{lllllll}\text { Day 0 } & 0.002 \pm 0.000 & 0.032 \pm 0.001 * * & 0.120 \pm 0.009 * * & 0.452 \pm 0.018 * * & 1.212 \pm 0.027 * * & 3.468 \pm 0.138 * * \\ \text { Day } 14 & 0.006 \pm 0.002 & 0.028 \pm 0.002 * * & 0.085 \pm 0.009 * * & 0.395 \pm 0.022 * * & 1.276 \pm 0.087 * * & 3.335 \pm 0.189 * * \\ \text { Day } 42 & 0.003 \pm 0.001 & 0.020 \pm 0.004 * * & 0.062 \pm 0.006 * * & 0.367 \pm 0.034 * * & 1.301 \pm 0.178 * * & 3.240 \pm 0.139 * * \\ \text { Day 126 } & 0.002 \pm 0.001 & 0.007 \pm 0.000 * * & 0.020 \pm 0.002 * * & 0.149 \pm 0.029 * * & 0.774 \pm 0.094 * & 3.062 \pm 0.291 * *\end{array}$ Total Lung Burden ( $\mu$ g L-MWNT-1020/lung)
Day 0
$0.382 \pm 0.092$
$6.177 \pm 0.219 * *$
$23.12 \pm 1.778 * * \quad 86.94 \pm 3.465^{* *} \quad 233.0 \pm 5.252 * *$
$666.9 \pm 26.61 * *$
Day 14
$1.11 \pm 0.37 \quad 5.34 \pm 0.44 * *$
$16.42 \pm 1.70 * *$
$76.00 \pm 4.27 * * \quad 245.33 \pm 16.71 * *$
$641.37 \pm 36.38 * *$
Day 42
$0.592 \pm 0.243$
$3.756 \pm 0.772 * *$
$1.92 \pm 1.146^{* *} 70.65 \pm 6.536 * * 250.2 \pm 34.24 * *$
$623.1 \pm 26.82 * *$
Day 126
$0.320 \pm 0.133 \quad 1.32$
$1.320 \pm 0.084 * * 3.88$
$886 \pm 0.437 * * 28$
$8.59 \pm 5.605^{* *}$
$148.8 \pm 18.10 * *$
$588.8 \pm 55.90 * *$

Normalized Lung Burden ( $\mu \mathrm{g}$ L-MWNT-1020/lung per $\mathrm{mg} / \mathrm{m}^{3}$ )

$\begin{array}{lllllll}\text { Day } 0 & - & 61.77 \pm 2.19 & 77.07 \pm 5.93 & 86.94 \pm 3.46 & 77.67 \pm 1.75 & 66.69 \pm 2.66 \\ \text { Day } 14 & - & 53.44 \pm 4.41 & 54.74 \pm 5.65 & 76.00 \pm 4.27 & 81.78 \pm 5.57 & 64.14 \pm 3.64 \\ \text { Day } 42 & - & 37.56 \pm 7.72 & 39.72 \pm 3.82 & 70.65 \pm 6.54 & 83.41 \pm 11.41 & 62.31 \pm 2.68 \\ \text { Day } 126 & - & 13.20 \pm 0.84 & 12.95 \pm 1.46 & 28.59 \pm 5.61 & 49.60 \pm 6.03 & 58.88 \pm 5.59\end{array}$

*Significantly different $(\mathrm{p} \leq 0.05)$ from the chamber control group by Williams' test.

**Significantly different $(\mathrm{p} \leq 0.01)$ from the chamber control group by Williams' test (lung weights) or Shirley's test (other parameters).

${ }^{\mathrm{a} N o t}$ applicable.

$\mathrm{b}_{\mathrm{n}}=4$.

As shown in Table 3, the clearance rates are similar in the 0.1 and $0.3 \mathrm{mg} / \mathrm{m}^{3}$ exposure groups, indicating half-lives in the range of 52 to 64 days. However, starting with the $1 \mathrm{mg} / \mathrm{m}^{3}$ exposure group, clearance rates become progressively slower, with half-lives increasing to as long as 465 (males) or 583 (female) days in the $10 \mathrm{mg} / \mathrm{m}^{3}$ exposure groups. This slowing of the clearance rate with increasing exposure concentration is potentially a result of lung overload. 
Table 3. Lung Deposition and Clearance Parameter Estimates for Rats in the 30-day Inhalation Study of 1020 Long Multiwalled Carbon Nanotubes

\begin{tabular}{|c|c|c|c|c|c|}
\hline & $0.1 \mathrm{mg} / \mathrm{m}^{3}$ & $0.3 \mathrm{mg} / \mathrm{m}^{3}$ & $1 \mathrm{mg} / \mathrm{m}^{3}$ & $3 \mathrm{mg} / \mathrm{m}^{3}$ & $10 \mathrm{mg} / \mathrm{m}^{3}$ \\
\hline \multicolumn{6}{|l|}{ Male } \\
\hline Initial Lung Burden ${ }^{\mathrm{a}}$ & $7.4 \pm 0.7$ & $23 \pm 1$ & $102 \pm 3$ & $278 \pm 4$ & $698 \pm 7$ \\
\hline $\mathrm{k}\left(\right.$ days $\left.^{-1}\right)$ & $0.013 \pm 0.003$ & $0.011 \pm 0.002$ & $0.0077 \pm 0.0006$ & $0.0043 \pm 0.0003$ & $0.0015 \pm 0.0002$ \\
\hline $\mathrm{t}_{1 / 2}$ (days) & $52 \pm 10$ & $64 \pm 8$ & $90 \pm 6$ & $160 \pm 11$ & $465 \pm 48$ \\
\hline \multicolumn{6}{|l|}{ Female } \\
\hline Initial Lung Burden & $6.1 \pm 0.7$ & $20 \pm 1$ & $87 \pm 2$ & $244 \pm 4$ & $652 \pm 6$ \\
\hline $\mathrm{k}\left(\right.$ days $\left.^{-1}\right)$ & $0.013 \pm 0.003$ & $0.013 \pm 0.002$ & $0.0092 \pm 0.0007$ & $0.0039 \pm 0.0003$ & $0.0012 \pm 0.0002$ \\
\hline $\mathrm{t}_{1 / 2}$ (days) & $54 \pm 11$ & $53 \pm 7$ & $76 \pm 5$ & $176 \pm 13$ & $583 \pm 75$ \\
\hline
\end{tabular}

\section{Thirty-day Core Study in Rats}

All core study animals survived to study termination (Table 4), and there were no treatmentrelated clinical observations. There were no statistically significant differences in body weight or body weight gain in any exposed group relative to the chamber controls (Table 4 and Figure 4).Upon gross examination, brown discoloration of the lungs was observed in most rats exposed to $3 \mathrm{mg} / \mathrm{m}^{3}$ of L-MWNT-1020 and all rats exposed to $10 \mathrm{mg} / \mathrm{m}^{3}$. In addition, the bronchial and mediastinal lymph nodes were enlarged and discolored (brown or gray) in all rats exposed to $10 \mathrm{mg} / \mathrm{m}^{3}$, in most rats exposed to $3 \mathrm{mg} / \mathrm{m}^{3}$, and in some rats exposed to $1 \mathrm{mg} / \mathrm{m}^{3}$. 
Table 4. Survival and Body Weights of Rats in the 30-day Inhalation Study of 1020 Long Multiwalled Carbon Nanotubes ${ }^{\mathrm{a}}$

\begin{tabular}{cccccc}
\hline $\begin{array}{c}\text { Concentration } \\
\left(\mathbf{m g} / \mathbf{m}^{\mathbf{3}}\right)\end{array}$ & Survival $^{\mathbf{b}}$ & $\begin{array}{c}\text { Initial Body } \\
\text { Weight }(\mathbf{g})\end{array}$ & $\begin{array}{c}\text { Final Body } \\
\text { Weight }(\mathbf{g})\end{array}$ & $\begin{array}{c}\text { Change in Body } \\
\text { Weight }(\mathbf{g})\end{array}$ & $\begin{array}{c}\text { Final Weight } \\
\text { Relative to } \\
\text { Controls (\%) }\end{array}$ \\
\hline Male & & & & \\
0 & $10 / 10$ & $125 \pm 3$ & $288 \pm 6$ & $164 \pm 5$ & 101 \\
0.1 & $10 / 10$ & $120 \pm 2$ & $291 \pm 4$ & $172 \pm 3$ & 97 \\
0.3 & $10 / 10$ & $117 \pm 2$ & $280 \pm 5$ & $163 \pm 6$ & 98 \\
1 & $10 / 10$ & $118 \pm 3$ & $282 \pm 7$ & $164 \pm 6$ & 101 \\
3 & $10 / 10$ & $123 \pm 3$ & $291 \pm 4$ & $168 \pm 4$ & 100 \\
10 & $10 / 10$ & $123 \pm 3$ & $289 \pm 7$ & $166 \pm 7$ & 101 \\
\hline Female & & & $88 \pm 2$ & 99 \\
0 & $10 / 10$ & $106 \pm 2$ & $194 \pm 3$ & $84 \pm 5$ & 101 \\
0.1 & $10 / 10$ & $108 \pm 2$ & $192 \pm 5$ & $88 \pm 2$ & 100 \\
\hline 0.3 & $10 / 10$ & $108 \pm 3$ & $195 \pm 3$ & $84 \pm 4$ \\
1 & $10 / 10$ & $108 \pm 2$ & $192 \pm 3$ & $88 \pm 3$ & \\
3 & $10 / 10$ & $108 \pm 2$ & $195 \pm 4$ & $90 \pm 2$ & \\
10 & $10 / 10$ & $104 \pm 3$ & $194 \pm 4$ & & \\
\hline aWeights and weight changes are given as mean \pm standard error. Differences from the chamber control group are not significant \\
by Dunnett's test. \\
bNumber of animals surviving at 31 (males) or 32 (females) days/number initially in group.
\end{tabular}


L-MWNT-1020, NTP TOX 94
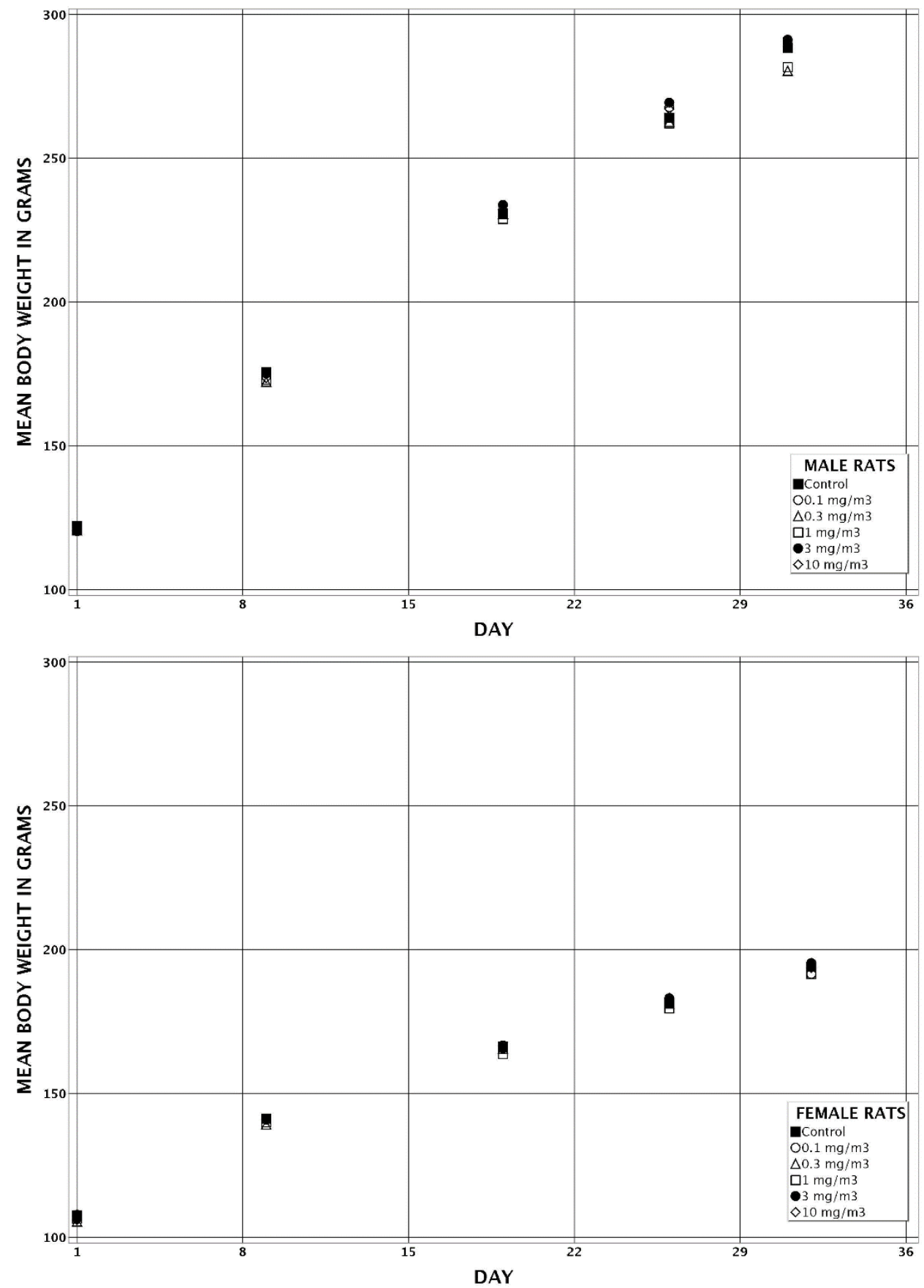

Figure 4. Growth Curves for Rats Exposed to 1020 Long Multiwalled Carbon Nanotubes by Inhalation for 30 Days 
The absolute and relative lung weights were significantly greater in the $10 \mathrm{mg} / \mathrm{m}^{3}$ dose group of female rats compared to chamber controls (Table B-1). Treatment-related microscopic changes were seen in the organs examined (nose, larynx, lung, and lung-associated lymph nodes).

Nose: There were increases in the accumulation of hyaline droplets in the olfactory epithelium, and to a lesser extent in the respiratory epithelium of the nose, in male and female rats when compared to chamber controls. In all cases, the lesions were graded as minimal (Table 5, Table A-1, and Table A-2). These increases were not statistically significant, nor was there a strong association with exposure, but the highest exposure groups tended to have the highest incidences. Additionally, this is a common treatment-related finding in inhalation studies. Hyaline droplets in the olfactory epithelium were discrete accretions of brightly eosinophilic, homogeneous material that filled and expanded the cytoplasm of affected lining cells, often displacing the nucleus. Affected cells were very few in number and were located in short rows in the olfactory epithelium lining the ventral meatus in Level III. The overall extent of this especially subtle finding in rats was lower than that seen in the mice.

Larynx: There were increases in the incidences of laryngeal epiglottic squamous metaplasia in male and female rats, although in all cases the severity grade was minimal (Table 5, Table A-1, and Table A-2). The incidences of epiglottic squamous metaplasia occurred with significant positive trends $(\mathrm{p}<0.001)$ in males and females, and in females exposed to $1 \mathrm{mg} / \mathrm{m}^{3}$ of LMWNT-1020 in males and females exposed to 3 and $10 \mathrm{mg} / \mathrm{m}^{3}$ the incidences were significantly increased compared to those in the chamber controls. Epiglottic squamous metaplasia was a subtle change in the lining epithelium at the base of the epiglottis. In affected animals, the normally cuboidal epithelium was focally replaced by a few layers of flattened, elongated, nonciliated, nonkeratinized, squamous cells. This change was always located in the central area of the epiglottic base.

Lung: There were exposure-related increases in the incidences of foreign body, chronic inflammation, and alveolar epithelial hyperplasia in both males and females. Foreign body was present in the lung of all exposed males and females, but in none of the chamber controls (Table A-1 and Table A-2). The average severity grade of the lesion in males and females increased with increasing exposure concentration above $0.3 \mathrm{mg} / \mathrm{m}^{3}$. The foreign body material consisted of variably abundant, homogeneous, black, discrete, nonbirefringent, round to irregularly shaped particles that ranged from less than $1 \mu \mathrm{m}$ to approximately $4 \mu \mathrm{m}$. These particles occurred singly or often appeared to be in agglomerations of multiple particles. Although not visible by light microscope, the presence of individual MWCNTs cannot be discounted. In animals with minimal severity, the foreign bodies were extremely scarce, with only small numbers or single cytoplasmic particles in a few macrophages scattered through alveolar spaces. In mild to moderate cases, the material was more abundant. It was typically located in the cytoplasm of macrophages and even multinucleated giant cells (often constituent cells of the frequently concurrent chronic inflammation). Rarely, bronchiolar epithelial cells also contained small amounts of foreign body material. Clumps of extracellular foreign body material occasionally appeared to be free in alveolar spaces, bronchiolar lumens, and the otherwise unremarkable bronchial-associated lymphoid tissue (BALT). The foreign body material was presumed to be the test article, thus it was not considered a lesion and was not included in Table 5, but is shown in Table A-1 and Table A-2. 
Table 5. Incidences of Nonneoplastic Lesions of the Respiratory System in Rats in the 30-day Inhalation Study of 1020 Long Multiwalled Carbon Nanotubes

\begin{tabular}{|c|c|c|c|c|c|c|}
\hline & $\begin{array}{l}\text { Chamber } \\
\text { Control }\end{array}$ & $0.1 \mathrm{mg} / \mathrm{m}^{3}$ & $0.3 \mathrm{mg} / \mathrm{m}^{3}$ & $1 \mathrm{mg} / \mathrm{m}^{3}$ & $3 \mathrm{mg} / \mathrm{m}^{3}$ & $10 \mathrm{mg} / \mathrm{m}^{3}$ \\
\hline \multicolumn{7}{|l|}{ Male } \\
\hline Nose $^{\mathrm{a}}$ & (10) & (10) & (10) & (10) & (10) & $(10)$ \\
\hline $\begin{array}{l}\text { Olfactory Epithelium, } \\
\text { Accumulation, } \\
\text { Hyaline Droplet }^{\mathrm{b}}\end{array}$ & 0 & $1(1.0)^{\mathrm{c}}$ & $3(1.0)$ & 0 & 0 & $3(1.0)$ \\
\hline $\begin{array}{l}\text { Respiratory Epithelium, } \\
\text { Accumulation, } \\
\text { Hyaline Droplet }\end{array}$ & 0 & 0 & 0 & 0 & $1(1.0)$ & $1(1.0)$ \\
\hline Larynx & (10) & (10) & (10) & (10) & (10) & (10) \\
\hline $\begin{array}{l}\text { Epiglottis, Metaplasia, } \\
\text { Squamous }\end{array}$ & 0 & 0 & 0 & $1(1.0)$ & $9 * *(1.0)$ & $9 * *(1.0)$ \\
\hline Lung & (10) & $(10)$ & $(10)$ & (10) & $(10)$ & (10) \\
\hline Inflammation, Chronic & $5(1.0)$ & $1(1.0)$ & $2(1.0)$ & $10 *(1.0)$ & $10 *(2.1)$ & $10^{*}(3.0)$ \\
\hline $\begin{array}{l}\text { Alveolar Epithelium, } \\
\text { Hyperplasia }\end{array}$ & 0 & 0 & 0 & $3(1.0)$ & $10 * *(1.7)$ & $10 * *(1.9)$ \\
\hline \multicolumn{7}{|l|}{ Female } \\
\hline Nose & (10) & (10) & (10) & (10) & (10) & (10) \\
\hline $\begin{array}{l}\text { Olfactory Epithelium, } \\
\text { Accumulation, } \\
\text { Hyaline Droplet }\end{array}$ & $1(1.0)$ & 0 & $1(1.0)$ & $1(1.0)$ & 0 & $4(1.0)$ \\
\hline $\begin{array}{l}\text { Respiratory Epithelium, } \\
\text { Accumulation, } \\
\text { Hyaline Droplet }\end{array}$ & 0 & 0 & 0 & 0 & 0 & $1(1.0)$ \\
\hline Larynx & (10) & (10) & (10) & (10) & (10) & (10) \\
\hline $\begin{array}{l}\text { Epiglottis, Metaplasia, } \\
\text { Squamous }\end{array}$ & 0 & $1(1.0)$ & 0 & $6^{* *}(1.0)$ & $9 * *(1.0)$ & $7 * *(1.0)$ \\
\hline Lung & (10) & $(10)$ & $(10)$ & (10) & (10) & $(10)$ \\
\hline Inflammation, Chronic & 0 & $3(1.0)$ & $2(1.0)$ & $6^{* *}(1.0)$ & $10 * *(1.8)$ & $10 * *(3.0)$ \\
\hline $\begin{array}{l}\text { Alveolar Epithelium, } \\
\text { Hyperplasia }\end{array}$ & 0 & 0 & 0 & $2(1.0)$ & $10 * *(1.1)$ & $10 * *(1.4)$ \\
\hline \multicolumn{7}{|c|}{$\begin{array}{l}\text { *Significantly different }(\mathrm{p} \leq 0.05) \text { from the chamber control group by the Fisher exact test. } \\
* * \mathrm{p} \leq 0.01 \text {. } \\
\text { aNumber of animals with tissue examined microscopically. } \\
\text { bNumber of animals with lesion. } \\
\text { cAverage severity grade of lesions in affected animals: } 1=\text { minimal, } 2=\text { mild, } 3=\text { moderate, } 4=\text { marked. }\end{array}$} \\
\hline \multicolumn{7}{|c|}{$\begin{array}{l}\text { The incidences of chronic inflammation were significantly increased in males and females } \\
\text { exposed to } 1,3 \text {, and } 10 \mathrm{mg} / \mathrm{m}^{3} \text { of L-MWNT-1020 (Table } 5 \text {, Table A-1, and Table A-2). The } \\
\text { chronic inflammation observed in the } 0.1,0.3 \text {, and } 1 \mathrm{mg} / \mathrm{m}^{3} \text { groups was minimal, as was that } \\
\text { observed in five male chamber controls. No female chamber controls exhibited chronic } \\
\text { inflammation. Severity of chronic inflammation increased with increasing exposure }\end{array}$} \\
\hline
\end{tabular}


concentration from minimal to moderate across the 1,3 , and $10 \mathrm{mg} / \mathrm{m}^{3}$ dose groups of males and females. Chronic inflammation was characterized by increased numbers of diffusely scattered macrophages in alveoli and clusters or aggregates of neutrophils and cellular debris admixed with macrophages near alveolar ducts and terminal bronchioles. In exposed animals, the cytoplasm of these macrophages often contained variable amounts of foreign body material. In minimal cases, there were only minor increases in numbers of small macrophages, which were scattered singly or in small clusters mainly in the alveolar spaces with less involvement of the alveolar ducts or terminal bronchioles, and essentially no involvement of the more proximal airways. With increasing severity (mild to moderate), macrophages were still most abundant in the distal airways (alveolar ducts, terminal bronchioles), but also occurred occasionally in the lumens of larger bronchioles and bronchi, in the otherwise unremarkable BALT, in the pleural connective tissue, and very rarely appeared to be present on the pulmonary pleural surface. In addition, the macrophages in higher severity cases (notable in those with a moderate severity grade) were often large with vesicular nuclei and abundant pale pinkish cytoplasm containing multiple foreign body particles (including those in the pleural connective tissue or on the pleural surface); multinucleated giant cells were rarely present. Other features of chronic inflammation, especially in moderate cases, included slight focal thickening of scattered alveolar septa by infiltrates of small mononuclear cells. In some cases, slightly increased interstitial collagen fibers also contributed to the alveolar septal thickening. The small mononuclear cells occasionally formed narrow perivascular cuffs around smaller blood vessels. Small foci of extravasated red blood cells were occasionally noted in scattered alveolar spaces or in the perivascular stroma.

Alveolar epithelial hyperplasia was observed in three males and two females exposed to $1 \mathrm{mg} / \mathrm{m}^{3}$ of L-MWNT-1020 and in all males and females in the 3 and $10 \mathrm{mg} / \mathrm{m}^{3}$ groups (Table 5 , Table A-1, and Table A-2). The average severity grades increased slightly with increasing exposure concentration in males and females. The incidences of alveolar epithelial hyperplasia in males and females exposed to 3 and $10 \mathrm{mg} / \mathrm{m}^{3}$ were significantly increased. Alveolar epithelial hyperplasia was characterized by short rows or clusters of crowded, plump, cuboidal epithelial cells along alveolar and alveolar duct walls that occasionally piled into multiple layers up to five cells thick. The alveolar epithelial hyperplasia was present concurrently with the chronic inflammation, suggesting that the hyperplasia was a response to alveolar epithelial injury.

Bronchial and mediastinal lymph nodes: In male and female rats, foreign body material was observed in the bronchial and mediastinal lymph nodes (Table A-1 and Table A-2). The foreign body was morphologically identical to that seen in the lungs and is presumed to be the test article. The foreign body was not considered a lesion so it was not included in Table 6 . The presence of foreign body generally increased in incidence with increasing exposure concentration in the bronchial and mediastinal lymph nodes, in both males and females. The incidences of foreign body in both sexes and both lymph nodes were significantly increased in the 1,3 , and $10 \mathrm{mg} / \mathrm{m}^{3}$ exposure groups, except for the mediastinal lymph node in male rats exposed to $1 \mathrm{mg} / \mathrm{m}^{3}$ of L-MWNT-1020. It was present mainly in macrophages within the paracortex and medullary cords, but there was some extracellular foreign material in the paracortex. The incidences of lymphoid hyperplasia in both lymph nodes were significantly increased in males and females exposed to 3 and $10 \mathrm{mg} / \mathrm{m}^{3}$ (except bronchial lymph node in males exposed at $10 \mathrm{mg} / \mathrm{m}^{3}$ ) as was the incidence in the mediastinal lymph node of female rats exposed to $1 \mathrm{mg} / \mathrm{m}^{3}$ (Table 6 , Table A-1, and Table A-2). The severity of lymphoid hyperplasia generally increased with increasing exposure concentration Table 6. 
Table 6. Incidences of Nonneoplastic Lesions of the Bronchial and Mediastinal Lymph Nodes in Rats in the 30-day Inhalation Study of 1020 Long Multiwalled Carbon Nanotubes

\begin{tabular}{|c|c|c|c|c|c|c|}
\hline & $\begin{array}{l}\text { Chamber } \\
\text { Control }\end{array}$ & $0.1 \mathrm{mg} / \mathrm{m}^{3}$ & $0.3 \mathrm{mg} / \mathrm{m}^{3}$ & $1 \mathrm{mg} / \mathrm{m}^{3}$ & $3 \mathrm{mg} / \mathrm{m}^{3}$ & $10 \mathrm{mg} / \mathrm{m}^{3}$ \\
\hline \multicolumn{7}{|l|}{ Male } \\
\hline Lymph Node, Bronchial $^{\mathrm{a}}$ & (6) & (6) & (9) & (7) & (7) & (7) \\
\hline Hyperplasia, Lymphoid ${ }^{\mathrm{b}}$ & 0 & 0 & 0 & 0 & $6^{* *}(2.0)^{\mathrm{c}}$ & $2(1.5)$ \\
\hline Lymph Node, Mediastinal & (7) & (9) & $(10)$ & (9) & (9) & $(10)$ \\
\hline Hyperplasia, Lymphoid & 0 & $3(1.7)$ & $1(1.0)$ & $3(1.3)$ & $8^{* *}(2.1)$ & $9^{* *}(2.7)$ \\
\hline \multicolumn{7}{|l|}{ Female } \\
\hline Lymph Node, Bronchial & (7) & (6) & (4) & (6) & (7) & (9) \\
\hline Hyperplasia, Lymphoid & 0 & $1(1.0)$ & 0 & $2(1.5)$ & $6^{* *}(1.7)$ & $7 * *(2.6)$ \\
\hline Lymph Node, Mediastinal & (10) & $(10)$ & (9) & $(10)$ & (10) & (10) \\
\hline Hyperplasia, Lymphoid & $2(1.0)$ & $3(1.0)$ & $3(1.7)$ & $7 *(2.0)$ & $9 * *(2.8)$ & $10 * *(3.4)$ \\
\hline \multicolumn{7}{|c|}{$\begin{array}{l}\text { *Significantly different }(\mathrm{p} \leq 0.05) \text { from the chamber control group by the Fisher exact test. } \\
* * \mathrm{p} \leq 0.01 \text {. } \\
\text { aNumber of animals with tissue examined microscopically. } \\
\text { bNumber of animals with lesion. } \\
\text { cAverage severity grade of lesions in affected animals: } 1=\text { minimal, } 2=\text { mild, } 3=\text { moderate, } 4=\text { marked. }\end{array}$} \\
\hline \multicolumn{7}{|c|}{$\begin{array}{l}\text { The lymphoid hyperplasia was characterized primarily by increased numbers of well- } \\
\text { differentiated, medium-sized to large mature lymphocytes in the paracortex and medullary cords. } \\
\text { More severe cases sometimes also had more prominent cortical germinal centers. The } \\
\text { enlargement of the bronchial and mediastinal lymph nodes seen at necropsy was attributed to the } \\
\text { lymphoid hyperplasia. }\end{array}$} \\
\hline
\end{tabular}

\section{Lung Burden Study in Mice}

Summaries of body weights, lung weights, and lung burdens for male and female tissue burden study mice are presented in Table 7 and Table C-2. Lung weights for males and females exposed to 3 or $10 \mathrm{mg} / \mathrm{m}^{3}$ were significantly greater than those in the chamber control groups on the last exposure day (postexposure day 0) and remained significantly greater throughout the postexposure period. The lung weight for females exposed to $1 \mathrm{mg} / \mathrm{m}^{3}$ was significantly increased relative to the chamber control group at postexposure day 0 , but not significantly different at any later postexposure timepoint.

Normalized lung burdens generally decreased with increasing postexposure time but were quite variable across the exposed groups of males and females (Table 7). Although normalized lung burdens in groups exposed to higher concentrations generally decreased less with postexposure time compared to groups exposed to lower concentrations, no consistent trends toward increased or decreased normalized lung burdens were observed. This was likely due to high variability in the sample mean estimates, which were calculated from small sample sizes. The typical sample size for lung burden studies range from 5 to 10 animals per sex per group. 


\section{Lung Clearance Kinetics}

Semilog plots of male and female lung burden versus days postexposure are presented in Figure C-6, Figure C-7, Figure C-8, Figure C-9, and Figure C-10. These plots also show the fit of the lung clearance model to the data; results of lung burden modeling are presented in Table 8 .

As shown in Figure C-6, Figure C-7, Figure C-8, Figure C-9, and Figure C-10, although there was considerable variability in the data, the model fits the data adequately. These figures also show that the slope of the line from the model fit progressively decreases as exposure concentrations increase, indicating significant decreases in the clearance rate constant with increasing exposure concentration.

\section{Lung Burden Modeling}

Comparison of model-estimated values of initial lung burdens in Table 8 with the lung burdens measured at the end of exposure (postexposure day 0; Table 7) indicates that the modelextrapolated burdens compare well with the actual lung burdens at that timepoint and increased approximately in proportion to exposure concentration.

Table 7. Postexposure Lung Weights, Nickel Concentrations and Burdens, and 1020 Long Multiwalled Carbon Nanotube Burdens for Mice in the 30-day Inhalation Study of 1020 Long Multiwalled Carbon Nanotubes

\begin{tabular}{|c|c|c|c|c|c|c|}
\hline & $\begin{array}{c}\text { Chamber } \\
\text { Control }\end{array}$ & $0.1 \mathrm{mg} / \mathrm{m}^{3}$ & $0.3 \mathrm{mg} / \mathrm{m}^{3}$ & $1 \mathrm{mg} / \mathrm{m}^{3}$ & $3 \mathrm{mg} / \mathrm{m}^{3}$ & $10 \mathrm{mg} / \mathrm{m}^{3}$ \\
\hline \multicolumn{7}{|l|}{$\mathbf{n}$} \\
\hline Day 0 & 10 & 10 & 10 & 10 & 10 & 10 \\
\hline Day 14 & 5 & 5 & 5 & 5 & 5 & 5 \\
\hline Day 42 & 5 & 5 & 5 & 5 & 5 & 5 \\
\hline Day 126 & 5 & 5 & 5 & 5 & 5 & 5 \\
\hline
\end{tabular}

Male

Lung Weight (g)
Day $0 \quad 0.153 \pm 0.003$
$0.155 \pm 0.004$
$0.149 \pm 0.002$
$0.160 \pm 0.003$
$0.181 \pm 0.004 * * 0.224 \pm 0.003 * *$
Day $14 \quad 0.164 \pm 0.006$
$0.160 \pm 0.005$
$0.165 \pm 0.008$
$0.170 \pm 0.001$
$0.190 \pm 0.003 * 0.274 \pm 0.012 * *$
Day $42 \quad 0.149 \pm 0.002$
$0.143 \pm 0.002$
$0.150 \pm 0.004$
$0.155 \pm 0.003$
$0.182 \pm 0.004 * * 0.237 \pm 0.007 * *$
Day $126 \quad 0.175 \pm 0.006$
$0.166 \pm 0.008$
$0.175 \pm 0.004$
$0.172 \pm 0.004$
$0.197 \pm 0.002 * * 0.231 \pm 0.003 * *$

Sample Concentration $(\mu \mathrm{g} \mathrm{Ni} / \mathrm{g})$

\begin{tabular}{lcccccc} 
Day 0 & $0.016 \pm 0.008$ & $0.053 \pm 0.003 * *$ & $0.180 \pm 0.036^{* *}$ & $0.546 \pm 0.014 * *$ & $1.324 \pm 0.033 * *$ & $2.582 \pm 0.075 * *$ \\
Day 14 & $0.065 \pm 0.054$ & $0.035 \pm 0.006$ & $0.092 \pm 0.010^{*}$ & $0.403 \pm 0.025 * *$ & $1.115 \pm 0.042 * *$ & $2.045 \pm 0.199 * *$ \\
Day 42 & $0.028 \pm 0.009$ & $0.053 \pm 0.013$ & $0.066 \pm 0.007 *$ & $0.267 \pm 0.025 * *$ & $1.001 \pm 0.046^{* *}$ & $2.356 \pm 0.082 * *$ \\
Day 126 & $0.008 \pm 0.000$ & $0.008 \pm 0.000$ & $0.021 \pm 0.008^{*}$ & $0.220 \pm 0.017 * *$ & $0.907 \pm 0.034 * *$ & $1.900 \pm 0.043 * *$ \\
Total Lung Burden $(\mu \mathrm{g} \mathrm{Ni} / \mathrm{lung})$ & & & & \\
Day 0 & $0.002 \pm 0.001$ & $0.008 \pm 0.000 * *$ & $0.027 \pm 0.005 * *$ & $0.087 \pm 0.002 * *$ & $0.239 \pm 0.005 * *$ & $0.578 \pm 0.017 * *$ \\
Day 14 & $0.011 \pm 0.009$ & $0.006 \pm 0.001$ & $0.015 \pm 0.001 *$ & $0.069 \pm 0.004 * *$ & $0.212 \pm 0.008^{* *}$ & $0.551 \pm 0.034 * *$ \\
\hline
\end{tabular}




\begin{tabular}{|c|c|c|c|c|c|c|}
\hline & $\begin{array}{c}\text { Chamber } \\
\text { Control }\end{array}$ & $0.1 \mathrm{mg} / \mathrm{m}^{3}$ & $0.3 \mathrm{mg} / \mathrm{m}^{3}$ & $1 \mathrm{mg} / \mathrm{m}^{3}$ & $3 \mathrm{mg} / \mathrm{m}^{3}$ & $10 \mathrm{mg} / \mathrm{m}^{3}$ \\
\hline Day 42 & $0.004 \pm 0.001$ & $0.008 \pm 0.002$ & $0.010 \pm 0.001 *$ & $0.042 \pm 0.004 * *$ & $0.183 \pm 0.010^{* *}$ & $0.557 \pm 0.015^{* *}$ \\
\hline Day 126 & $0.001 \pm 0.000$ & $0.001 \pm 0.000$ & $0.004 \pm 0.001$ & $0.038 \pm 0.003 * *$ & $0.179 \pm 0.008^{* *}$ & $0.438 \pm 0.014^{* *}$ \\
\hline \multicolumn{7}{|c|}{ Total Lung Burden ( $\mu$ g L-MWNT-1020/lung) } \\
\hline Day 0 & $0.46 \pm 0.23$ & $1.57 \pm 0.08 * *$ & $5.11 \pm 0.96^{* *}$ & $16.81 \pm 0.42 * *$ & $45.97 \pm 0.92 * *$ & $111.09 \pm 3.18^{* *}$ \\
\hline Day 14 & $2.11 \pm 1.76$ & $1.11 \pm 0.21$ & $2.88 \pm 0.26^{*}$ & $13.20 \pm 0.84 * *$ & $40.78 \pm 1.51 * *$ & $105.93 \pm 6.53 * *$ \\
\hline Day 42 & $0.79 \pm 0.25$ & $1.45 \pm 0.33$ & $1.89 \pm 0.17 *$ & $7.98 \pm 0.84 * *$ & $35.15 \pm 1.87 * *$ & $107.15 \pm 2.85^{* *}$ \\
\hline Day 126 & $0.27 \pm 0.01$ & $0.26 \pm 0.01$ & $0.72 \pm 0.27$ & $7.29 \pm 0.62 * *$ & $34.45 \pm 1.63 * *$ & $84.31 \pm 2.61 * *$ \\
\hline \multicolumn{7}{|c|}{ Normalized Lung Burden ( $\mu$ g L-MWNT-1020/lung per mg/m³) } \\
\hline Day 0 & $-^{\mathrm{a}}$ & $15.73 \pm 0.83$ & $17.03 \pm 3.21$ & $16.81 \pm 0.42$ & $15.32 \pm 0.31$ & $11.11 \pm 0.32$ \\
\hline Day 14 & - & $11.07 \pm 2.15$ & $9.61 \pm 0.88$ & $13.20 \pm 0.84$ & $13.59 \pm 0.50$ & $10.59 \pm 0.65$ \\
\hline Day 42 & - & $14.46 \pm 3.34$ & $6.29 \pm 0.56$ & $7.98 \pm 0.84$ & $11.72 \pm 0.62$ & $10.72 \pm 0.28$ \\
\hline Day 126 & - & $2.56 \pm 0.13$ & $2.39 \pm 0.88$ & $7.29 \pm 0.62$ & $11.48 \pm 0.54$ & $8.43 \pm 0.26$ \\
\hline
\end{tabular}

\section{Female}

Lung Weight (g)
Day $0 \quad 0.148 \pm 0.002$
$0.154 \pm 0.002$
$0.156 \pm 0.003$
$0.161 \pm 0.002 * * 0.181 \pm 0.003 * * 0.215 \pm 0.003 * *$
Day $14 \quad 0.159 \pm 0.004$
$0.154 \pm 0.003$
$0.158 \pm 0.004$
$0.165 \pm 0.002$
$0.185 \pm 0.006 * * 0.252 \pm 0.008^{* *}$
Day 42
$0.162 \pm 0.005$
$0.168 \pm 0.004$
$0.167 \pm 0.003$
$0.194 \pm 0.004 * * 0.232 \pm 0.006 * *$
Day $126 \quad 0.174 \pm 0.003$
$0.166 \pm 0.005$
$0.164 \pm 0.003$
$0.167 \pm 0.003$
$0.191 \pm 0.006^{* *} 0.239 \pm 0.004 * *$

Sample Concentration $(\mu \mathrm{g} \mathrm{Ni} / \mathrm{g})$

$\begin{array}{lll}\text { Day } 0 & 0.008 \pm 0.000 & 0.056 \pm 0.005^{* *}\end{array}$

Day $14 \quad 0.013 \pm 0.005 \quad 0.065 \pm 0.029 *$

$0.121 \pm 0.004 * * 0.494 \pm 0.016^{* *} 1.168 \pm 0.030^{* *} 2.609 \pm 0.056^{* *}$

Day $42 \quad 0.013 \pm 0.005 \quad 0.037 \pm 0.018$

$0.085 \pm 0.011 * * 0.443 \pm 0.039 * * 1.109 \pm 0.040 * * 2.275 \pm 0.059 * *$

Day $126 \quad 0.008 \pm 0.000 \quad 0.016 \pm 0.008$

$0.062 \pm 0.006 * * 0.302 \pm 0.013 * * 1.034 \pm 0.017 * * 2.448 \pm 0.039 * *$

Total Lung Burden ( $\mu \mathrm{g} \mathrm{Ni/lung)}$

\begin{tabular}{|c|c|c|c|c|c|c|}
\hline Day 0 & $0.001 \pm 0.000$ & $0.009 \pm 0.001 * *$ & $0.019 \pm 0.000 * *$ & $0.079 \pm 0.002^{* *}$ & $0.212 \pm 0.007 * *$ & $0.561 \pm 0.013 * *$ \\
\hline Day 14 & $0.002 \pm 0.001$ & $0.010 \pm 0.005^{*}$ & $0.013 \pm 0.002 * *$ & $0.073 \pm 0.007 * *$ & $0.204 \pm 0.007 * *$ & $0.573 \pm 0.013 * *$ \\
\hline Day 42 & $0.002 \pm 0.001$ & $0.006 \pm 0.003$ & $0.010 \pm 0.001^{* *}$ & $0.050 \pm 0.002 * *$ & $0.201 \pm 0.006^{* *}$ & $0.568 \pm 0.014 * *$ \\
\hline Day 126 & $0.001 \pm 0.000$ & $0.003 \pm 0.002$ & $0.003 \pm 0.001$ & $0.015 \pm 0.001 * *$ & $0.173 \pm 0.007 * *$ & $0.491 \pm 0.011 * *$ \\
\hline \multicolumn{7}{|c|}{ Total Lung Burden ( $\mu$ g L-MWNT-1020/lung) } \\
\hline Day 0 & $0.23 \pm 0.00$ & $1.67 \pm 0.15^{* *}$ & $3.61 \pm 0.07 * *$ & $15.25 \pm 0.37 * *$ & $40.80 \pm 1.32 * *$ & $107.88 \pm 2.53 * *$ \\
\hline Day 14 & $0.40 \pm 0.15$ & $1.92 \pm 0.87^{*}$ & $2.59 \pm 0.30^{* *}$ & $14.10 \pm 1.31^{* *}$ & $39.31 \pm 1.39 * *$ & $110.13 \pm 2.59 * *$ \\
\hline Day 42 & $0.41 \pm 0.16$ & $1.14 \pm 0.56$ & $2.00 \pm 0.16^{* *}$ & $9.66 \pm 0.46^{* *}$ & $38.58 \pm 1.07 * *$ & $109.27 \pm 2.74 * *$ \\
\hline Day 126 & $0.27 \pm 0.00$ & $0.54 \pm 0.29$ & $0.67 \pm 0.14$ & $2.95 \pm 0.24 * *$ & $33.33 \pm 1.34 * *$ & $94.39 \pm 2.14 * *$ \\
\hline
\end{tabular}




\begin{tabular}{|c|c|c|c|c|c|c|}
\hline & $\begin{array}{l}\text { Chamber } \\
\text { Control }\end{array}$ & $0.1 \mathrm{mg} / \mathrm{m}^{3}$ & $0.3 \mathrm{mg} / \mathrm{m}^{3}$ & $1 \mathrm{mg} / \mathrm{m}^{3}$ & $3 \mathrm{mg} / \mathrm{m}^{3}$ & $10 \mathrm{mg} / \mathrm{m}^{3}$ \\
\hline \multicolumn{7}{|c|}{ Normalized Lung Burden ( $\mu$ g L-MWNT-1020/lung per mg $/ \mathrm{m}^{3}$ ) } \\
\hline Day 0 & - & $16.69 \pm 1.48$ & $12.05 \pm 0.24$ & $15.25 \pm 0.37$ & $13.60 \pm 0.44$ & $10.79 \pm 0.25$ \\
\hline Day 14 & - & $19.18 \pm 8.70$ & $8.63 \pm 1.01$ & $14.10 \pm 1.31$ & $13.10 \pm 0.46$ & $11.01 \pm 0.26$ \\
\hline Day 42 & - & $11.36 \pm 5.62$ & $6.68 \pm 0.54$ & $9.66 \pm 0.46$ & $12.86 \pm 0.36$ & $10.93 \pm 0.27$ \\
\hline Day 126 & - & $5.41 \pm 2.92$ & $2.23 \pm 0.47$ & $2.95 \pm 0.24$ & $11.11 \pm 0.45$ & $9.44 \pm 0.21$ \\
\hline
\end{tabular}

*Significantly different $(\mathrm{p} \leq 0.05)$ from the chamber control group by Williams' test (lung weights) or Shirley's test (other parameters).

$* * \mathrm{p} \leq 0.01$.

aNot applicable.

As shown in Table 8, the clearance rates are similar in the $0.1,0.3$, and $1 \mathrm{mg} / \mathrm{m}^{3}$ exposure groups, indicating half-lives in the range of 47 to 96 days. However, starting with the $3 \mathrm{mg} / \mathrm{m}^{3}$ exposure group, clearance rates become progressively slower, with half-lives increasing to as long as 337 (males) to 649 (females) days in the $10 \mathrm{mg} / \mathrm{m}^{3}$ exposure groups. This slowing of the clearance rate with increasing exposure concentration is potentially a result of lung overload.

Table 8. Lung Deposition and Clearance Parameter Estimates for Mice in the 30-day Inhalation Study of 1020 Long Multiwalled Carbon Nanotubes

\begin{tabular}{|c|c|c|c|c|c|}
\hline & $0.1 \mathrm{mg} / \mathrm{m}^{3}$ & $0.3 \mathrm{mg} / \mathrm{m}^{3}$ & $1 \mathrm{mg} / \mathrm{m}^{3}$ & $3 \mathrm{mg} / \mathrm{m}^{3}$ & $10 \mathrm{mg} / \mathrm{m}^{3}$ \\
\hline \multicolumn{6}{|l|}{ Male } \\
\hline Initial Lung Burden $^{\mathrm{a}}$ & $1.4 \pm 0.4$ & $4 \pm 1$ & $15 \pm 1$ & $43 \pm 2$ & $111 \pm 3$ \\
\hline $\mathrm{k}\left(\right.$ days $\left.^{-1}\right)$ & $0.007 \pm 0.01$ & $0.015 \pm 0.006$ & $0.0085 \pm 0.002$ & $0.0024 \pm 0.0007$ & $0.0021 \pm 0.0004$ \\
\hline $\mathrm{t}_{1 / 2}$ (days) & $96 \pm 61$ & $47 \pm 13$ & $82 \pm 14$ & $293 \pm 70$ & $337 \pm 59$ \\
\hline \multicolumn{6}{|l|}{ Female } \\
\hline Initial Lung Burden & $1.4 \pm 0.4$ & $3 \pm 1$ & $16 \pm 1$ & $40 \pm 2$ & $110 \pm 3$ \\
\hline $\mathrm{k}\left(\right.$ days $\left.^{-1}\right)$ & $0.010 \pm 0.01$ & $0.013 \pm 0.005$ & $0.013 \pm 0.002$ & $0.0015 \pm 0.0007$ & $0.0011 \pm 0.0004$ \\
\hline $\mathrm{t}_{1 / 2}$ (days) & $70 \pm 38$ & $53 \pm 14$ & $54 \pm 7$ & $448 \pm 141$ & $649 \pm 183$ \\
\hline
\end{tabular}

\section{Thirty-day Core Study in Mice}

All core study animals survived to study termination (Table 9), and there were no treatmentrelated clinical observations. There were no statistically significant differences in body weight or body weight gain in any exposed group relative to the chamber controls (Table 9 and Figure 5). Grossly, brown discoloration of the lungs was observed in male and female mice exposed to 3 or $10 \mathrm{mg} / \mathrm{m}^{3}$. In addition, brown discoloration of bronchial and mediastinal lymph nodes was observed in most exposed female mice and all male mice exposed to 3 or $10 \mathrm{mg} / \mathrm{m}^{3}$. 
Table 9. Survival and Body Weights of Mice in the 30-day Inhalation Study of 1020 Long Multiwalled Carbon Nanotubes ${ }^{\mathrm{a}}$

\begin{tabular}{cccccc}
\hline $\begin{array}{c}\text { Concentration } \\
\left(\mathbf{m g} \mathbf{m}^{\mathbf{3}}\right)\end{array}$ & Survival $^{\mathbf{b}}$ & $\begin{array}{c}\text { Initial Body } \\
\text { Weight }(\mathbf{g})\end{array}$ & $\begin{array}{c}\text { Final Body } \\
\text { Weight }(\mathbf{g})\end{array}$ & $\begin{array}{c}\text { Change in Body } \\
\text { Weight }(\mathbf{g})\end{array}$ & $\begin{array}{c}\text { Final Weight } \\
\text { Relative to } \\
\text { Controls (\%) }\end{array}$ \\
\hline Male & & & & \\
0 & $10 / 10$ & $22.6 \pm 0.3$ & $27.9 \pm 0.4$ & $5.3 \pm 0.2$ & 99 \\
0.1 & $10 / 10$ & $22.3 \pm 0.4$ & $27.6 \pm 0.3$ & $5.3 \pm 0.4$ & 98 \\
0.3 & $10 / 10$ & $22.3 \pm 0.4$ & $27.3 \pm 0.5$ & $5.1 \pm 0.3$ & 97 \\
1 & $10 / 10$ & $22.2 \pm 0.3$ & $27.2 \pm 0.3$ & $5.0 \pm 0.3$ & 99 \\
3 & $10 / 10$ & $22.2 \pm 0.4$ & $27.5 \pm 0.5$ & $5.3 \pm 0.4$ & 100 \\
10 & $10 / 10$ & $22.6 \pm 0.3$ & $27.8 \pm 0.5$ & $5.2 \pm 0.2$ & 98 \\
\hline Female & & & & 100 \\
0 & $10 / 10$ & $19.1 \pm 0.3$ & $24.4 \pm 0.5$ & $5.4 \pm 0.4$ & 101 \\
0.1 & $10 / 10$ & $19.0 \pm 0.2$ & $24.1 \pm 0.3$ & $5.1 \pm 0.3$ & 97 \\
0.3 & $10 / 10$ & $19.4 \pm 0.3$ & $24.5 \pm 0.4$ & $5.1 \pm 0.3$ & 101 \\
\hline 1 & $10 / 10$ & $19.4 \pm 0.2$ & $24.7 \pm 0.3$ & $5.4 \pm 0.4$ & \\
3 & $10 / 10$ & $18.6 \pm 0.2$ & $23.8 \pm 0.3$ & $5.2 \pm 0.3$ & \\
10 & $10 / 10$ & $19.0 \pm 0.2$ & $24.8 \pm 0.3$ & $5.8 \pm 0.2$ & \\
\hline aWeights and weight changes are given as mean \pm standard error. Differences from the chamber control group are not significant \\
by Dunnett's test. \\
bNumber of animals surviving at 31 (males) or 32 (females) days/number initially in group.
\end{tabular}


L-MWNT-1020, NTP TOX 94
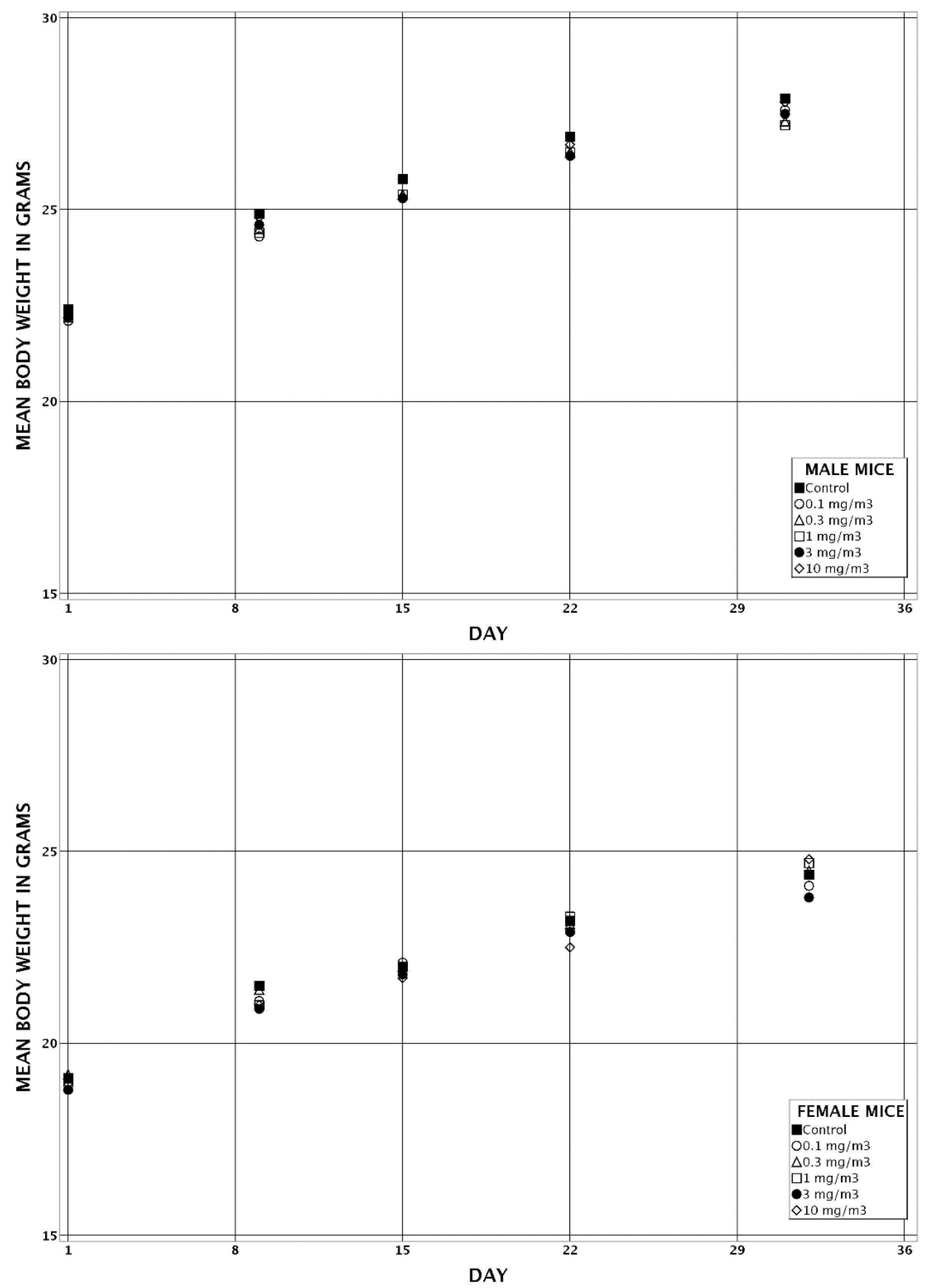

Figure 5. Growth Curves for Mice Exposed to 1020 Long Multiwalled Carbon Nanotubes by Inhalation for 30 Days 
Compared to those of the chamber controls, the absolute and relative lung weights were significantly greater in male and female mice exposed to 3 or $10 \mathrm{mg} / \mathrm{m}^{3}$ of L-MWNT-1020 (Table B-2). Treatment-related microscopic changes were seen in the organs examined (nose, larynx, lung, and lung-associated lymph nodes).

Nose: The incidences of accumulation of hyaline droplets in the olfactory epithelium were significantly increased in females exposed to $3 \mathrm{mg} / \mathrm{m}^{3}$ of L-MWNT-1020 and in males and females exposed to $10 \mathrm{mg} / \mathrm{m}^{3}$, and the incidences of this lesion in the respiratory epithelium were significantly increased in females exposed to $1 \mathrm{mg} / \mathrm{m}^{3}$ and in males and females exposed to 3 and $10 \mathrm{mg} / \mathrm{m}^{3}$ (Table 10, Table A-3, and Table A-4). The average severity grade of these lesions increased in the $10 \mathrm{mg} / \mathrm{m}^{3}$ exposure groups. Overall, this response was more extensive in mice than in the rats. The morphologic appearance of the hyaline droplets was identical to that seen in the rats. In mice, they occurred most commonly at the junction of the respiratory and olfactory epithelia along the septum and nasoturbinates in Level 2 and in the ventral half of Level 3.

Larynx: There were significant increases in the incidences of epiglottic squamous metaplasia in the larynges of males exposed to $1 \mathrm{mg} / \mathrm{m}^{3}$ and males and females exposed to 3 and $10 \mathrm{mg} / \mathrm{m}^{3}$ of L-MWNT-1020 (Table 10, Table A-3, and Table A-4). In males, the incidences increased with increasing exposure concentration, and the severity (minimal to mild) increased slightly in the 3 and $10 \mathrm{mg} / \mathrm{m}^{3}$ exposure groups. In females, the incidences increased with increasing exposure concentration beginning at $1 \mathrm{mg} / \mathrm{m}^{3}$, and the severity increased from minimal in the $3 \mathrm{mg} / \mathrm{m}^{3}$ exposure group to mild in the $10 \mathrm{mg} / \mathrm{m}^{3}$ exposure group. Epiglottic squamous metaplasia was localized to the base of the epiglottis and was characterized by replacement of the normal, ciliated columnar epithelium by a stratified squamous epithelium composed of aciliate, polygonal to flattened cells with variable keratinization. The metaplastic squamous epithelium was as thick as four to six cell layers in the most severe cases.

Lung: There were exposure-related increases in the incidences of foreign body, chronic inflammation, alveolar proteinosis, and bronchiolar epithelial hyperplasia in both males and females (Table 10, Table A-3, and Table A-4). Foreign body occurred in all exposed males and females, except for one animal each in the male and female $0.1 \mathrm{mg} / \mathrm{m}^{3}$ exposure groups. Foreign body was not observed in the chamber controls. Foreign body accumulation was minimal in the 0.1 and $0.3 \mathrm{mg} / \mathrm{m}^{3}$ exposure groups and increased with increasing exposure concentration in the higher exposure groups. The foreign body material was morphologically identical to that seen in rats. It was found in the cytoplasm of bronchiolar and alveolar lining cells, alveolar macrophages, and multinucleated giant cells, and free within the bronchiolar lumina and alveolar spaces. The foreign body material was presumed to be the test article, thus it was not considered a lesion and was not included in Table 10 but is shown in Table A-3 and Table A-4.

Chronic inflammation occurred in males and females exposed to 1,3 , and $10 \mathrm{mg} / \mathrm{m}^{3}$ of LMWNT-1020, and the incidences were significantly increased compared to those in the chamber controls where the lesion did not occur (Table 10, Table A-3, and Table A-4). The chronic inflammation observed was similar to that seen in rats. In mice, macrophages were occasionally seen in the lymphatics adjacent to small blood vessels. Alveoli containing clumps of macrophages were noted throughout the lobar parenchyma, but there was a tendency, especially in moderate cases, for large clusters of macrophages to occur in alveoli directly subjacent to the pleura. Unlike the rats, macrophages were not noted in BALT, pulmonary connective tissue, or the pleural surface. 
Table 10. Incidences of Nonneoplastic Lesions of the Respiratory System in Mice in the 30-day Inhalation Study of 1020 Long Multiwalled Carbon Nanotubes

\begin{tabular}{|c|c|c|c|c|c|c|}
\hline & $\begin{array}{c}\text { Chamber } \\
\text { Control }\end{array}$ & $0.1 \mathrm{mg} / \mathrm{m}^{3}$ & $0.3 \mathrm{mg} / \mathrm{m}^{3}$ & $1 \mathrm{mg} / \mathrm{m}^{3}$ & $3 \mathrm{mg} / \mathrm{m}^{3}$ & $10 \mathrm{mg} / \mathrm{m}^{3}$ \\
\hline \multicolumn{7}{|l|}{ Male } \\
\hline Nose $^{a}$ & (10) & $(10)$ & (10) & (10) & (10) & (10) \\
\hline $\begin{array}{l}\text { Olfactory Epithelium, } \\
\text { Accumulation, } \\
\text { Hyaline Droplet }^{\mathrm{b}}\end{array}$ & 0 & 0 & 0 & 0 & $2(1.0)^{\mathrm{c}}$ & $9^{* *}(1.2)$ \\
\hline $\begin{array}{l}\text { Respiratory Epithelium, } \\
\text { Accumulation, } \\
\text { Hyaline Droplet }\end{array}$ & 0 & 0 & 0 & $3(1.0)$ & $9 * *(1.0)$ & $10 * *(1.6)$ \\
\hline Larynx & (9) & (10) & (10) & (10) & (10) & (10) \\
\hline $\begin{array}{l}\text { Epiglottis, Metaplasia, } \\
\text { Squamous }{ }^{\mathrm{c}}\end{array}$ & $1(1.0)$ & $2(1.0)$ & $3(1.0)$ & $6^{*}(1.0)$ & $9^{* *}(1.1)$ & $10^{* *}(1.4)$ \\
\hline Lung & (10) & (10) & (10) & (10) & (10) & (10) \\
\hline Inflammation, Chronic & 0 & 0 & 0 & $8^{* *}(1.0)$ & $10 * *(1.2)$ & $10^{* *}(2.6)$ \\
\hline Alveolus, Proteinosis & 0 & 0 & 0 & 0 & $3(1.0)$ & $10 * *(1.9)$ \\
\hline $\begin{array}{l}\text { Bronchiole, Epithelium, } \\
\text { Hyperplasia }\end{array}$ & 0 & 0 & 0 & 0 & $7 * *(1.0)$ & $10 * *(1.6)$ \\
\hline \multicolumn{7}{|l|}{ Female } \\
\hline Nose & (10) & (10) & (10) & (10) & (10) & (10) \\
\hline $\begin{array}{l}\text { Olfactory Epithelium, } \\
\text { Accumulation, } \\
\text { Hyaline Droplet }\end{array}$ & 0 & 0 & $1(1.0)$ & $3(1.0)$ & $8 * *(1.0)$ & $10 * *(1.8)$ \\
\hline $\begin{array}{l}\text { Respiratory Epithelium, } \\
\text { Accumulation, } \\
\text { Hyaline Droplet }\end{array}$ & 0 & 0 & 0 & $8^{* *}(1.0)$ & $10 * *(1.1)$ & $10 * *(2.0)$ \\
\hline Larynx & (10) & (10) & (10) & (10) & (10) & (10) \\
\hline $\begin{array}{l}\text { Epiglottis, Metaplasia, } \\
\text { Squamous }\end{array}$ & $1(1.0)$ & $1(1.0)$ & $1(1.0)$ & $4(1.0)$ & $6 *(1.0)$ & $10^{* *}(1.9)$ \\
\hline Lung & (10) & (10) & (10) & (10) & $(10)$ & $(10)$ \\
\hline Inflammation, Chronic & 0 & 0 & 0 & $4 *(1.0)$ & $10 * *(1.3)$ & $10 * *(2.8)$ \\
\hline Alveolus, Proteinosis & 0 & 0 & 0 & 0 & $9 * *(1.0)$ & $10 * *(1.6)$ \\
\hline $\begin{array}{l}\text { Bronchiole, Epithelium, } \\
\text { Hyperplasia }\end{array}$ & 0 & 0 & 0 & 0 & $6 * *(1.0)$ & $10 * *(1.3)$ \\
\hline
\end{tabular}

*Significantly different $(\mathrm{p} \leq 0.05)$ from the chamber control group by the Fisher exact test.

$* * \mathrm{p} \leq 0.01$.

${ }^{a}$ Number of animals with tissue examined microscopically.

${ }^{b}$ Number of animals with lesion.

${ }^{\mathrm{c}}$ Average severity grade of lesions in affected animals: $1=$ minimal, $2=$ mild, $3=$ moderate, $4=$ marked. 
Alveolar proteinosis occurred in three male mice exposed to $3 \mathrm{mg} / \mathrm{m}^{3}$ and nine female mice exposed to $3 \mathrm{mg} / \mathrm{m}^{3}$ of L-MWNT-1020, and in all males and females exposed to $10 \mathrm{mg} / \mathrm{m}^{3}$ (Table 10, Table A-3, and Table A-4). The incidences in females exposed to $3 \mathrm{mg} / \mathrm{m}^{3}$ and males and females exposed to $10 \mathrm{mg} / \mathrm{m}^{3}$ were significantly increased compared to those in the chamber controls. The severity of the alveolar proteinosis was minimal in the $3 \mathrm{mg} / \mathrm{m}^{3}$ exposure groups but increased in males and female exposed to $10 \mathrm{mg} / \mathrm{m}^{3}$. Alveolar proteinosis was characterized as aggregates of finely granular, pale eosinophilic material in the alveolar spaces, occasionally in the alveolar ducts, and very rarely in the terminal bronchioles. It was often intermingled with, but always clearly distinct from, the intraluminal black foreign body material.

Bronchiolar epithelial hyperplasia occurred in only males and females exposed to 3 and $10 \mathrm{mg} / \mathrm{m}^{3}$, and the incidences were significantly increased compared to those in the chamber controls (Table 10, Table A-3, and Table A-4). Bronchiolar epithelial hyperplasia was a minimal to mild change that affected only some airways in a given lung and was most prominent in the smaller and terminal bronchioles. Compared to the chamber controls, the lining epithelium of scattered terminal bronchioles in affected lungs had focal to confluent areas with increased numbers of plump, variably ciliated, cuboidal cells, often crowded into multiple layers two to five cells thick or even forming small papillary projections. These hyperplastic cells sometimes extended from the terminal bronchioles to line the adjacent alveolar ducts, but this was uncommon. Small focal areas of hyperplastic cells were also noted occasionally in the lining epithelium of larger bronchioles.

Bronchial and mediastinal lymph nodes: In male and female mice, foreign body and lymphoid hyperplasia were observed in the bronchial and mediastinal lymph nodes (Table 11, Table A-3, and Table A-4). In males, the incidences of foreign body were significantly increased in the bronchial lymph node in the 1,3 , and $10 \mathrm{mg} / \mathrm{m}^{3}$ exposure groups compared to the chamber controls. In females, foreign body was significantly increased in the 3 and $10 \mathrm{mg} / \mathrm{m}^{3}$ exposure groups in the bronchial lymph node and in the $10 \mathrm{mg} / \mathrm{m}^{3}$ exposure group in the mediastinal lymph node compared to the chamber controls. The severity of the foreign body in both lymph nodes of males and females was minimal, with the exception of the bronchial lymph node in males exposed to $10 \mathrm{mg} / \mathrm{m}^{3}$ in which one animal had mildly severe foreign body occurrence. The foreign body material was morphologically identical to that seen in the lungs of the rats and mice and in the lung-associated lymph nodes in rats; because the material was not seen in controls, it is presumed to be the test article. It was located in a few, widely scattered resident macrophages in the paracortex and medullary cords or apparently extracellular in the paracortex. Foreign body was not considered a lesion so it was not included in Table 11 but is shown in Table A-3 and Table A-4.

In males, lymphoid hyperplasia of the bronchial and mediastinal lymph nodes occurred in the 1, 3 , and $10 \mathrm{mg} / \mathrm{m}^{3}$ exposure groups and was not observed in chamber controls (Table 11 and Table A-3). The incidence of bronchial lymphoid hyperplasia in males exposed to $3 \mathrm{mg} / \mathrm{m}^{3} \mathrm{was}$ significantly increased compared to that in the chamber controls. The severity of this lesion in males tended to increase with increasing exposure concentration, although there was a slight decrease in severity in the $10 \mathrm{mg} / \mathrm{m}^{3}$ exposure group compared to the $3 \mathrm{mg} / \mathrm{m}^{3}$ exposure group. In females, lymphoid hyperplasia of the bronchial and mediastinal lymph nodes occurred in the 1,3 , and $10 \mathrm{mg} / \mathrm{m}^{3}$ exposure groups; one chamber control female had lymphoid hyperplasia in the bronchial lymph node (Table 11 and Table A-4). In females exposed to $10 \mathrm{mg} / \mathrm{m}^{3}$, the incidences of lymphoid hyperplasia in both lymph nodes were significantly increased compared 
to those in the chamber controls. As with the males, the severity of the lesion tended to increase with increasing exposure concentration.

Lymphoid hyperplasia in both lymph nodes and in both sexes was characterized by increased numbers of well-differentiated, medium-sized to large lymphocytes primarily in the paracortex and to a lesser extent in the medullary cords (Table 11, Table A-3, and Table A-4).

Table 11. Incidences of Nonneoplastic Lesions of the Bronchial and Mediastinal Lymph Nodes in Mice in the 30-day Inhalation Study of 1020 Long Multiwalled Carbon Nanotubes

\begin{tabular}{|c|c|c|c|c|c|c|}
\hline & $\begin{array}{c}\text { Chamber } \\
\text { Control }\end{array}$ & $0.1 \mathrm{mg} / \mathrm{m}^{3}$ & $0.3 \mathrm{mg} / \mathrm{m}^{3}$ & $1 \mathrm{mg} / \mathrm{m}^{3}$ & $3 \mathrm{mg} / \mathrm{m}^{3}$ & $10 \mathrm{mg} / \mathrm{m}^{3}$ \\
\hline \multicolumn{7}{|l|}{ Male } \\
\hline Lymph Node, Bronchial $^{\mathrm{a}}$ & (6) & (9) & (7) & (7) & (9) & (7) \\
\hline Hyperplasia, Lymphoid ${ }^{\mathrm{b}}$ & 0 & 0 & 0 & $2(1.0)^{\mathrm{c}}$ & $5 *(1.8)$ & $3(1.7)$ \\
\hline Lymph Node, Mediastinal & (9) & (7) & (8) & $(10)$ & (9) & (9) \\
\hline Hyperplasia, Lymphoid & 0 & 0 & 0 & $1(2.0)$ & $1(3.0)$ & $3(2.7)$ \\
\hline \multicolumn{7}{|l|}{ Female } \\
\hline Lymph Node, Bronchial & (9) & (3) & (8) & (9) & (6) & (6) \\
\hline Hyperplasia, Lymphoid & $1(1.0)$ & 0 & 0 & $2(1.0)$ & $3(1.3)$ & $5 *(1.8)$ \\
\hline Lymph Node, Mediastinal & $(7)$ & (8) & (8) & (7) & (10) & (9) \\
\hline Hyperplasia, Lymphoid & 0 & 0 & 0 & $1(2.0)$ & $1(2.0)$ & $5^{*}(1.4)$ \\
\hline
\end{tabular}

*Significantly different $(\mathrm{p} \leq 0.05)$ from the chamber control group by the Fisher exact test.

${ }^{a}$ Number of animals with tissue examined microscopically.

${ }^{b}$ Number of animals with lesion.

${ }^{\mathrm{c}}$ Average severity grade of lesions in affected animals: $1=$ minimal, $2=$ mild, $3=$ moderate, $4=$ marked. 


\section{Discussion}

The toxicity of inhaled multiwalled carbon nanotubes (MWCNTs) has been evaluated in several studies in rodents ${ }^{51-56 ; 65 ; 99}$; however, the physical aspects and purity of MWCNTs are diverse, and the critical physical and chemical properties associated with potential toxicity are currently unknown. The nonfunctionalized 1020 Long Multiwalled Carbon Nanotube (L-MWNT-1020) was selected for whole-body inhalation testing because large quantities of highly pure (98\% pure) material are commercially available, and because L-MWNT-1020 is a long, thin, agglomerated MWCNT for which limited inhalation toxicity data are available. L-MWNT-1020 nanotubes are composed almost entirely of carbon and are stable and chemically unreactive. For these reasons, the potential pulmonary toxicity of L-MWNT-1020 is primarily a function of physical dimensions, exposure concentrations, and biopersistence. The potential toxicity of MWCNTs are a concern, in part, because their physical dimensions are similar to those of known toxic and carcinogenic fibers, such as asbestos ${ }^{4 ; 100 ; 101}$. However, unlike relatively rigid and straight MWCNTs (e.g., Mitsui-7), the thinner and more flexible L-MWNT-1020 nanotubes (average $15 \mathrm{~nm}$ diameter and $2.6 \mu \mathrm{m}$ long) form entangled agglomerates that are less likely to penetrate the pleura and produce asbestos-like pulmonary responses. The "cotton ball" agglomerates were a respirable size (less than $3 \mu \mathrm{m}$ ) with a "hairy" surface consisting of numerous ends of L-MWNT-1020. However, individual or small clusters of MWCNT would not be visible by light microscopy ${ }^{102}$. Free L-MWNT-1020 agglomerates (i.e., not within macrophages or other cells) were not observed in or on the pleura of exposed animals in the current studies. The macrophages containing L-MWNT-1020 agglomerates that were seen in the pleural connective tissue or on the pleural surface were likely trafficking through the lymphatics to the bronchial and mediastinal lymph nodes, where similar macrophages were observed.

In the current studies, repeated inhalation exposures of rats and mice to L-MWNT-1020 resulted in increased lung weights and histopathologic lesions in the nose, larynx, lung, and bronchial and mediastinal lymph nodes without affecting animal survival. In general, histopathologic lesions occurred in animals exposed to $1 \mathrm{mg}$ L-MWNT-1020/ $\mathrm{m}^{3}$ or higher and progressed in incidences and/or severities with increasing exposure concentration. These target sites in the rodent respiratory tract are not unique to L-MWNT-1020 and have been observed in inhalation studies of agglomerated $\mathrm{MWCNT}^{49 ; 52}$, as well as more rigid, dispersed $\mathrm{MWCNT}^{42 ; 56}$.

Chronic pulmonary inflammation was one of the most severe lesions in animals exposed to LMWNT-1020. Mild to moderate chronic inflammation of the lung occurred in all rats and mice exposed to 3 or $10 \mathrm{mg} / \mathrm{m}^{3}$, and severity was minimal to mild in most animals exposed to $1 \mathrm{mg} / \mathrm{m}^{3}$. Pulmonary inflammation is the most reported effect of inhaled nanomaterials $\mathrm{s}^{42 ; 54-56 ; 103-}$ ${ }^{109}$. In the current studies, chronic inflammation was characterized by increased numbers of macrophages in the alveoli, and clusters of neutrophils and macrophages mixed with cellular debris near alveolar ducts and terminal bronchioles. Because of their role in accumulating and removing particulate matter from the lung, alveolar macrophages and neutrophils are a major target of inhaled carbon nanotubes $(\mathrm{CNT})^{110}$. Single or groups of agglomerated L-MWNT-1020 were observed in the cytoplasm of alveolar macrophages in exposed rats and mice. The persistence of indigestible materials in the phagolysosome has been associated with production of reactive oxygen species ${ }^{111 ; 112}$ that may contribute to the inflammation and tissue damage caused by L-MWNT-1020. CNT also have been shown to stimulate macrophages to produce pro-inflammatory cytokines and chemokines ${ }^{56 ; 113-118}$. Although the mechanism is not clear, 
several studies suggest that CNT may trigger the activation of the Nlrp3 inflammasome complex in macrophages and other phagocytic cells, resulting in caspase-1-mediated activation and release of pro-inflammatory cytokines ${ }^{110 ; 119-121}$. The ensuing pulmonary inflammatory response normally results in clearance of the foreign particles, tissue repair, and recovery; however, repeated exposure to a biopersistent CNT like L-MWNT-1020 can result in chronic inflammation and tissue damage ${ }^{122}$.

The epithelium lining the respiratory tract received significant exposure to inhaled MWCNT. Histopathologic changes were observed in the epithelium of the nose, larynx, airways, and lungs of animals exposed to L-MWNT-1020. In the lung, minimal to mild alveolar (rats) and bronchiolar (mice) epithelial hyperplasia occurred in all animals exposed to $10 \mathrm{mg} / \mathrm{m}^{3}$, and in all rats and most mice exposed to $3 \mathrm{mg} / \mathrm{m}^{3}$. Alveolar epithelium hyperplasia is a proliferation of Type II epithelial cells, the precursors for Type I epithelial cells. Hyperplasia of Type II cells is often observed following injury and loss of Type I epithelial cells and is typically accompanied by inflammation ${ }^{123}$. Direct evidence of epithelial cell damage, such as necrosis or degeneration, was not observed in the lungs of animals exposed to L-MWNT-1020. However, epithelial hyperplasia occurred concurrently with chronic inflammation, suggesting that the hyperplasia was a response to alveolar epithelial injury.

The most common pathologic findings in the respiratory tract of rodents exposed to chemicals by inhalation are those related to irritation of the nasal and laryngeal epithelium ${ }^{124}$. Because rodents are obligate nose breathers, the nasal cavity is the major portal of entry for inhaled particles, and as the initial deposition site in the respiratory tract, the nose receives the highest concentrations of inhaled particulates. The only exposure-related effect observed in the nasal cavity of animals exposed to L-MWNT-1020 was a concentration-related increase in the incidences of hyaline droplet accumulation in the olfactory and respiratory epithelium. These lesions occurred at higher incidences in mice than in rats and were of minimal severity in both species. Hyaline droplet accumulation may have been the result of irritation of the nasal epithelium caused by the deposition and accumulation of L-MWNT-1020 nanotubes at these sites. The nasal mucosa is protected by a thin layer of mucus; however, penetration of the mucous layer by nanotubes is possible. Hyaline droplet accumulation in the nasal epithelium is commonly reported in rodent inhalation studies. Hyaline droplets are identified microscopically as eosinophilic inclusions in the cytoplasm of epithelial cells, and although their significance is unknown, they may reflect a defensive response to exposure ${ }^{125 ; 126}$. Hyaline droplet accumulation in the nasal cavity has been reported in inhalation studies of other $\mathrm{MWCNT}^{49 ; 52 ; 55 ; 56}$.

The incidences of laryngeal epiglottal squamous metaplasia were significantly increased in a concentration-dependent manner in rats and mice exposed to $1 \mathrm{mg} / \mathrm{m}^{3} \mathrm{~L}-\mathrm{MWNT}-1020$ or greater. Squamous epithelium metaplasia of the larynx is one of the most commonly observed lesions in rodent inhalation studies ${ }^{127-129}$, and the base of the epiglottis is the most sensitive region for development of squamous metaplasia in response to an irritant ${ }^{130 ; 131}$. Because the rodent larynx is nearly linear to the nasal turbinates, inhaled particles impact directly on the anterior surface of the larynx ${ }^{124}$. Metaplasia is a common response to repeated irritation, and results in replacement of a sensitive epithelium by the more resistant squamous epithelium ${ }^{126 ; 132}$. Minimal squamous metaplasia of the larynx generally is considered an adaptive response, not an adverse effect ${ }^{129}$. Laryngeal epiglottal squamous metaplasia has been noted in inhalation studies of other MWCNT ${ }^{52 ; 55}$. 
Pulmonary alveolar proteinosis (PAP) occurred in mice exposed to the two highest concentrations of L-MWNT-1020 but did not occur in rats. PAP is characterized by abnormal surfactant accumulation in the lungs potentially resulting in respiratory insufficiency ${ }^{133}$. The most common clinical forms of this disease in humans are autoimmune $\mathrm{PAP}^{134}$, and hereditary PAP ${ }^{135 ; 136}$; however, PAP can also occur secondary to chronic dust exposure ${ }^{137}$. Secondary PAP has been associated with human exposures to inorganic dusts (silica, cement, titanium, and aluminum), organic dusts (sawdust, fertilizer, bakery flour, and others), fumes (chlorine, varnish, and others), and fibers (cellulose insulation) ${ }^{138-147}$. The pathogenesis of secondary PAP is poorly understood but may be caused by increased surfactant production by alveolar Type II epithelial cells and/or decreased surfactant clearance due to macrophage impairment. Hyperplasia of Type II epithelium in mice exposed to L-MWNT-1020 may have resulted in increased production or decreased recycling of surfactant by these cells. In addition, macrophage clearance and catabolism of excess surfactant may have been inhibited by the accumulation of L-MWNT-1020 in the lungs. Macrophages laden with L-MWNT-1020 were observed in the lungs of exposed mice, especially at higher exposure concentrations. Repeated exposure to L-MWNT-1020 may have maintained the macrophage overload and further reduced surfactant clearance. One other MWCNT (Nanocyl ${ }^{\circledR} \mathrm{NC} 7000^{\mathrm{TM}}$ ) has been reported to cause PAP in male and female Wistar rats $^{52}$. Rats were exposed to Nanocyl aerosol (head-nose only) for 6 hours per day for 13 weeks at target concentrations of $0,0.1,0.5$, or $2.5 \mathrm{mg} / \mathrm{m}^{3}$; PAP was diagnosed in rats exposed to 0.5 or $2.5 \mathrm{mg} / \mathrm{m}^{3}$. Nanocyl NC7000 is a long, thin MWCNT that forms respirable agglomerates, similar to L-MWNT-1020.

L-MWNT-1020 agglomerates and lymphoid hyperplasia were observed in the bronchial and mediastinal lymph nodes of exposed rats and mice. Both the amount of agglomerated L-MWNT1020 and the incidences of lymphoid hyperplasia generally increased with increasing exposure concentration in the bronchial and mediastinal lymph nodes. Particles that deposit in the alveoli are normally engulfed by alveolar macrophages and then removed from the lung by mucociliary clearance or by migration to the pulmonary lymph nodes ${ }^{148 ; 149}$. However, during repeated exposure, if the rate of deposition exceeds the maximum rate of clearance, particles will accumulate until the ability of the macrophages to clear the particles is impaired. Impairment of macrophage function then leads to further accumulation of particles and lung overload ${ }^{47}$.

As summarized by Cullen et al. ${ }^{150}$, hallmarks of lung overload by poorly soluble particles, such as L-MWNT-1020 include: persistent lung inflammation, increased epithelial proliferation, increased translocation of particles into the lung interstitial space and accumulation in lymph nodes, and decreased clearance of particles from the lung. In addition, alveolar macrophage clearance is compromised in lung overload when the volume of test material burden reaches approximately $6 \%$ of the total alveolar macrophage volume $e^{47 ; 151}$, or when the surface area exceeds the threshold for overload ${ }^{152}$. In the current studies, most of these hallmarks occurred in rats and mice exposed to $3 \mathrm{mg} / \mathrm{m}^{3}$ of L-MWNT-1020 or greater. First, chronic active lung inflammation occurred in all rats and mice exposed to 3 or $10 \mathrm{mg} / \mathrm{m}^{3}$. Second, alveolar epithelium hyperplasia occurred in all rats exposed to 3 or $10 \mathrm{mg} / \mathrm{m}^{3}$ and bronchiolar epithelium hyperplasia occurred in all mice exposed to $10 \mathrm{mg} / \mathrm{m}^{3}$. Third, translocation of L-MWNT-1020 to mediastinal and/or bronchial lymph nodes was evident histologically in these groups. Fourth, clearance rates were progressively much slower for rats and mice exposed to 3 or $10 \mathrm{mg} / \mathrm{m}^{3}$, which supports impaired lung clearance in these groups. In addition, the L-MWNT-1020 lung burden volume and/or surface area required to reach overload was exceeded in the 3 and 
$10 \mathrm{mg} / \mathrm{m}^{3}$ exposure groups. Calculations based on L-MWNT-1020 surface area show that as little as $171 \mu \mathrm{g}$ in rats or 14 to $22 \mu \mathrm{g}$ in mice can result in the onset of lung overload; these levels of lung burden were achieved in both the 3 and $10 \mathrm{mg} / \mathrm{m}^{3}$ exposure groups. Similarly, calculations based on L-MWNT-1020 bulk particle density indicate that as little as $400 \mu \mathrm{g}$ in rats, or 33 to $50 \mu \mathrm{g}$ in mice can result in onset of lung overload; these levels of lung burden were achieved in the $10 \mathrm{mg} / \mathrm{m}^{3}$ exposure groups. Collectively, all these findings indicate that lung overload occurred in the current studies in groups of rats and mice exposed to 3 or $10 \mathrm{mg} / \mathrm{m}^{3}$.

Few inhalation studies have measured lung burden and correlated lung overload with toxicity of MWCNT. Lung overload conditions were reported in one inhalation toxicity study of Baytubes, an agglomerated $\mathrm{MWCNT}^{49}$. Male Wistar rats were exposed to $0,0.1,0.4,1.5$, or $6 \mathrm{mg} / \mathrm{m}^{3}$ of Baytubes for 6 hours per day, 5 days per week, for 13 weeks. Similar to the current studies, lung histopathology included parameters associated with inflammation, including focal-widespread terminal bronchiole/alveolus inflammatory cell influx, hypercellularity at the bronchoalveolar junction, interstitial thickening of the alveolus, and particle-laden macrophages. Terminal bronchiole/alveolus hyperplasia, although not observed after 13 weeks of exposure, was observed during the 26-week recovery period. Lung elimination half-lives for male rats were increased in a dose-dependent manner, and subsequent calculations suggest that severely impaired clearance or complete stasis occurred in the 1.5 and $6 \mathrm{mg} / \mathrm{m}^{3}$ exposure groups. Pauluhn concluded that the inflammation and toxicity observed in exposed animals were predominately due to lung overload rather than an intrinsic toxicity of the MWCNT, minimal to moderate lung overload occurred in the 0.1 and $0.4 \mathrm{mg} / \mathrm{m}^{3}$ exposure groups, and the no-observed-adverse-effect level was $0.1 \mathrm{mg} / \mathrm{m}^{3}$ based on the nasal and pulmonary responses ${ }^{49}$.

In this study, lung overload conditions were reached for groups exposed to $3 \mathrm{mg} / \mathrm{m}^{3}$ or greater and histopathology in these groups was generally consistent with an inflammatory response. Most of these lesions were also present in the $1 \mathrm{mg} / \mathrm{m}^{3}$ exposure groups, although the incidences and severities were generally lower. It is unclear to what extent, if any, lung burden contributed to the observed lesions. There were no significantly increased lesions in the respiratory tract of animals exposed to $0.3 \mathrm{mg} / \mathrm{m}^{3}$ or lower of L-MWNT-1020. Consistent with these results, $0.3 \mathrm{mg} / \mathrm{m}^{3}$ is considered the no-observed-adverse-effect level for L-MWNT-1020. Cumulatively, the histologic findings in the lungs of chronic active inflammation and alveolar/bronchiolar hyperplasia, the large lung burdens, the slow clearance rates, and lung burden volumes and surface areas above the thresholds for overload indicate that lung overload conditions occurred in animals exposed to $3 \mathrm{mg} / \mathrm{m}^{3}$ of L-MWNT-1020 or greater.

The lowest exposure concentration used in the 30 -day studies $\left(0.1 \mathrm{mg} / \mathrm{m}^{3}\right)$ was the lowest achievable concentration that could be generated and monitored within the National Toxicology Program (NTP) specifications $( \pm 10 \%)$. These levels are also comparable to those used in the nose-only inhalation study of Pauluhn et al. ${ }^{54}\left(0.1-6 \mathrm{mg} / \mathrm{m}^{3}\right)$ in which toxicological effects were noted. The exposure concentrations used in this study were approximately 100 -fold higher than the NIOSH-proposed a recommended exposure limit for carbon nanotubes of $1 \mu \mathrm{g} / \mathrm{m}^{3}$ elemental carbon as a respirable mass 8-hour time-weighted average concentration ${ }^{36}$. NIOSH researchers have also evaluated exposure in multiple U.S. manufacturers of CNTs and nanofibers and reported inhalable exposures of MWCNT of up to $0.4 \mathrm{mg} / \mathrm{m}^{3}{ }^{153}$. Given the long half-life and persistence of MWCNT in the lung, even short periods of exposure at such levels would lead to chronic high-level exposures. Therefore, although the no-observed-adverse-effect level determined in the present study $\left(0.3 \mathrm{mg} / \mathrm{m}^{3}\right)$ is approximately 300 -fold higher than the 
recommended exposure limit, it is within the range observed in occupational settings and may be informative regarding potential health risks associated with occupational exposures to CNTs. 


\section{References}

1. Tolles WM. Self-assembled materials. Mater Res Soc Bull. 2000; October:36-38. http://dx.doi.org/10.1557/mrs2000.202

2. Donaldson K, Aitken R, Tran L, Stone V, Duffin R, Forrest G, Alexander A. Carbon nanotubes: A review of their properties in relation to pulmonary toxicology and workplace safety. Toxicol Sci. 2006; 92(1):5-22. http://dx.doi.org/10.1093/toxsci/kfj130

3. Collins PG, Avouris P. Nanotubes for electronics. Sci Am. 2000; 283(6):62-69. http://dx.doi.org/10.1038/scientificamerican1200-62

4. Pacurari M, Castranova V, Vallyathan V. Single-and multi-wall carbon nanotubes versus asbestos: Are the carbon nanotubes a new health risk to humans? J Toxicol Environ Health, A. 2010; 73(5-6):378-395. http://dx.doi.org/10.1080/15287390903486527

5. Banerjee S, Kahn MGC, Wong SS. Rational chemical strategies for carbon nanotube functionalization. Chemistry. 2003; 9(9):1898-1908. http://dx.doi.org/10.1002/chem.200204618

6. Hou P-X, Xu S-T, Ying Z, Yang Q-H, Liu C, Cheng H-M. Hydrogen adsorption/desorption behavior of multi-walled carbon nanotubes with different diameters. Carbon. 2003; 41(13):2471-2476. http://dx.doi.org/10.1016/S0008-6223(03)00271-9

7. Thostenson ET, Ren Z, Chou T-W. Advances in the science and technology of carbon nanotubes and their composites: A review. Compos Sci Technol. 2001; 61(13):18991912. http://dx.doi.org/10.1016/S0266-3538(01)00094-X

8. De Volder MF, Tawfick SH, Baughman RH, Hart AJ. Carbon nanotubes: Present and future commercial applications. Science. 2013; 339(6119):535-539.

9. Murr LE, Guerrero PA. Carbon nanotubes in wood soot. Atmos Sci Lett. 2006; 7(4):93-95. http://dx.doi.org/10.1002/asl.138

10. Bang JJ, Guerrero PA, Lopez DA, Murr LE, Esquivel EV. Carbon nanotubes and other fullerene nanocrystals in domestic propane and natural gas combustion streams. $\mathrm{J}$ Nanosci Nanotechnol. 2004; 4(7):716-718. http://dx.doi.org/10.1166/jnn.2004.095

11. BCC Research. Global markets and technologies for carbon nanotubes. 2015. Report Code: NAN024F. http://www.bccresearch.com/market-research/nanotechnology/carbonnantubes-global-markets-technologies-report-nan024f.html [Accessed: July 28, 2016]

12. Eklund P, Ajayan P, Blackmon R, Hart AJ, Kong J, Pradhan B, Rao A, Rinzler A. WTEC panel report on international assessment of research and development of carbon nanotube manufacturing and applications. Baltimore, MD: World Technology Evaluation Center, Inc; 2007.

13. Chou T-W, Gao L, Thostenson ET, Zhang Z, Byun J-H. An assessment of the science and technology of carbon nanotube-based fibers and composites. Compos Sci Technol. 2010; 70(1):1-19. http://dx.doi.org/10.1016/j.compscitech.2009.10.004

14. Mehra NK, Palakurthi S. Interactions between carbon nanotubes and bioactives: A drug delivery perspective. Drug Discov Today. 2016; 21(4):585-597. http://dx.doi.org/10.1016/j.drudis.2015.11.011

15. Shim M, Shi Kam NW, Chen RJ, Li Y, Dai H. Functionalization of carbon nanotubes for biocompatibility and biomolecular recognition. Nano Lett. 2002; 2(4):285-288. http://dx.doi.org/10.1021/n1015692j 
16. Pantarotto D, Briand J-P, Prato M, Bianco A. Translocation of bioactive peptides across cell membranes by carbon nanotubes. Chem Commun. 2004; (1):16-17. http://dx.doi.org/10.1039/b311254c

17. Shi Kam NW, Jessop TC, Wender PA, Dai H. Nanotube molecular transporters: Internalization of carbon nanotube- protein conjugates into mammalian cells. J Am Chem Soc. 2004; 126(22):6850-6851. http://dx.doi.org/10.1021/ja0486059

18. Bianco A, Kostarelos K, Partidos CD, Prato M. Biomedical applications of functionalised carbon nanotubes. Chem Commun. 2005; (5):571-577. http://dx.doi.org/10.1039/b410943k

19. Zharov VP, Kim J-W, Curiel DT, Everts M. Self-assembling nanoclusters in living systems: Application for integrated photothermal nanodiagnostics and nanotherapy. Nanomed Nanotechnol Biol Med. 2005; 1(4):326-345. http://dx.doi.org/10.1016/j.nano.2005.10.006

20. Liu Z, Winters M, Holodniy M, Dai H. siRNA delivery into human T cells and primary cells with carbon-nanotube transporters. Angew Chem Int Ed. 2007; 46(12):2023-2027. http://dx.doi.org/10.1002/anie.200604295

21. Lalwani G, Henslee AM, Farshid B, Lin L, Kasper FK, Qin Y-X, Mikos AG, Sitharaman B. Two-dimensional nanostructure-reinforced biodegradable polymeric nanocomposites for bone tissue engineering. Biomacromolecules. 2013; 14(3):900-909. http://dx.doi.org/10.1021/bm301995s

22. Bello D, Hart AJ, Ahn K, Hallock M, Yamamoto N, Garcia EJ, Ellenbecker MJ, Wardle BL. Particle exposure levels during CVD growth and subsequent handling of verticallyaligned carbon nanotube films. Carbon. 2008; 46(6):974-977. http://dx.doi.org/10.1016/j.carbon.2008.03.003

23. Bello D, Wardle BL, Yamamoto N, Guzman deVilloria R, Garcia EJ, Hart AJ, Ahn K, Ellenbecker MJ, Hallock M. Exposure to nanoscale particles and fibers during machining of hybrid advanced composites containing carbon nanotubes. J Nanopart Res. 2009; 11(1):231-249. http://dx.doi.org/10.1007/s11051-008-9499-4

24. Bello D, Wardle BL, Zhang J, Yamamoto N, Santeufemio C, Hallock M, Virji MA. Characterization of exposures to nanoscale particles and fibers during solid core drilling of hybrid carbon nanotube advanced composites. Int J Occup Environ Health. 2010; 16(4):434-450. http://dx.doi.org/10.1179/oeh.2010.16.4.434

25. Han JH, Lee EJ, Lee JH, So KP, Lee YH, Bae GN, Lee S-B, Ji JH, Cho MH, Yu IJ. Monitoring multiwalled carbon nanotube exposure in carbon nanotube research facility. Inhal Toxicol. 2008; 20(8):741-749. http://dx.doi.org/10.1080/08958370801942238

26. Tsai S-J, Hofmann M, Hallock M, Ada E, Kong J, Ellenbecker M. Characterization and evaluation of nanoparticle release during the synthesis of single-walled and multiwalled carbon nanotubes by chemical vapor deposition. Environ Sci Technol. 2009; 43(15):6017-6023. http://dx.doi.org/10.1021/es900486y

27. Lee JH, Lee S-B, Bae GN, Jeon KS, Yoon JU, Ji JH, Sung JH, Lee BG, Lee JH, Yang JS. Exposure assessment of carbon nanotube manufacturing workplaces. Inhal Toxicol. 2010; 22(5):369-381. http://dx.doi.org/10.3109/08958370903367359

28. Methner M, Hodson L, Dames A, Geraci C. Nanoparticle emission assessment technique (NEAT) for the identification and measurement of potential inhalation exposure to engineered nanomaterials - Part B: Results from 12 field studies. J Occup Env Hyg. 2010; 7(3):163-176. http://dx.doi.org/10.1080/15459620903508066 
29. Cena LG, Peters TM. Characterization and control of airborne particles emitted during production of epoxy/carbon nanotube nanocomposites. J Occup Env Hyg. 2011; 8(2):8692. http://dx.doi.org/10.1080/15459624.2011.545943

30. Dahm MM, Evans DE, Schubauer-Berigan MK, Birch ME, Fernback JE. Occupational exposure assessment in carbon nanotube and nanofiber primary and secondary manufacturers. Ann Occup Hyg. 2012; 56(5):542-556.

31. Kuijpers E, Bekker C, Fransman W, Brouwer D, Tromp P, Vlaanderen J, Godderis L, Hoet P, Lan Q, Silverman D. Occupational exposure to multi-walled carbon nanotubes during commercial production synthesis and handling. Ann Occup Hyg. 2015; 60(3):305-317. http://dx.doi.org/10.1093/annhyg/mev082

32. Johnson DR, Methner MM, Kennedy AJ, Steevens JA. Potential for occupational exposure to engineered carbon-based nanomaterials in environmental laboratory studies. Environ Health Perspect. 2009; 118(1):49-54. http://dx.doi.org/10.1289/ehp.0901076

33. Guseva-Canu I, Bateson TF, Bouvard V, Debia M, Dion C, Savolainen K, Yu I-J. Human exposure to carbon-based fibrous nanomaterials: A review. Int J Hyg Environ Health. 2016; 219(2):166-175. http://dx.doi.org/10.1016/j.ijheh.2015.12.005

34. Maynard AD, Kuempel ED. Airborne nanostructured particles and occupational health. J Nanopart Res. 2005; 7(6):587-614. http://dx.doi.org/10.1007/s11051-005-6770-9

35. Occupational Safety and Health Administration (OSHA). OSHA fact sheet 3634: Working safely with nanomaterials. Washington, DC: U.S. Department of Labor, OSHA; 2013. https://www.osha.gov/publications/OSHA_FS-3634.pdf [Accessed June 27, 2016]

36. National Institute for Occupational Safety and Health (NIOSH). Current intelligence bulletin 65: Occupational exposure to carbon nanotubes and nanofibers. Cincinnati, OH: U.S. Department of Health and Human Services, Centers for Disease Control and Prevention, NIOSH; 2013. DHHS (NIOSH) Publication No. 2013-145.

37. Osier M, Oberdörster G. Intratracheal inhalation vs intratracheal instillation: Differences in particle effects. Fundam Appl Toxicol. 1997; 40(2):220-227. http://dx.doi.org/10.1006/faat.1997.2390

38. Warheit DB, Laurence BR, Reed KL, Roach DH, Reynolds GAM, Webb TR. Comparative pulmonary toxicity assessment of single-wall carbon nanotubes in rats. Toxicol Sci. 2004; 77(1):117-125. http://dx.doi.org/10.1093/toxsci/kfg228

39. Morrow PE, Haseman JK, Hobbs CH, Driscoll KE, Vu V, Oberdorster G. The maximum tolerated dose for inhalation bioassays: Toxicity vs overload. Toxicol Sci. 1996; 29(2):155-167. http://dx.doi.org/10.1006/faat.1996.0017

40. Ryman-Rasmussen JP, Cesta MF, Brody AR, Shipley-Phillips JK, Everitt JI, Tewksbury EW, Moss OR, Wong BA, Dodd DE, Andersen ME. Inhaled carbon nanotubes reach the subpleural tissue in mice. Nat Nanotechnol. 2009; 4(11):747. http://dx.doi.org/10.1038/nnano.2009.305

41. Mercer RR, Scabilloni JF, Hubbs AF, Battelli LA, McKinney W, Friend S, Wolfarth MG, Andrew M, Castranova V, Porter DW. Distribution and fibrotic response following inhalation exposure to multi-walled carbon nanotubes. Part Fibre Toxicol. 2013; 10(1):33. http://dx.doi.org/10.1186/1743-8977-10-33

42. Porter DW, Hubbs AF, Chen BT, McKinney W, Mercer RR, Wolfarth MG, Battelli L, Wu N, Sriram K, Leonard S. Acute pulmonary dose-responses to inhaled multi-walled carbon nanotubes. Nanotoxicology. 2012; 7(7):1179-1194. http://dx.doi.org/10.3109/17435390.2012.719649 
43. Lippmann M. Asbestos exposure indices. Environ Res. 1988; 46(1):86-106. http://dx.doi.org/10.1016/S0013-9351(88)80061-6

44. Lippmann M. Effects of fiber characteristics on lung deposition, retention, and disease. Environ Health Perspect. 1990; 88:311-317. http://dx.doi.org/10.1289/ehp.9088311

45. Sanchez VC, Weston P, Yan A, Hurt RH, Kane AB. A 3-dimensional in vitro model of epithelioid granulomas induced by high aspect ratio nanomaterials. Part Fibre Toxicol. 2011; 8(1):17. http://dx.doi.org/10.1186/1743-8977-8-17

46. Murphy FA, Schinwald A, Poland CA, Donaldson K. The mechanism of pleural inflammation by long carbon nanotubes: Interaction of long fibres with macrophages stimulates them to amplify pro-inflammatory responses in mesothelial cells. Part Fibre Toxicol. 2012; 9(1):8. http://dx.doi.org/10.1186/1743-8977-9-8

47. Morrow PE. Dust overloading of the lungs: Update and appraisal. Toxicol Appl Pharmacol. 1992; 113(1):1-12. http://dx.doi.org/10.1016/0041-008X(92)90002-A

48. Oberdörster GJPE, Ferin J, Morrow PE. Volumetric loading of alveolar macrophages (AM): A possible basis for diminished AM-mediated particle clearance. Exp Lung Res. 1992; 18(1):87-104. http://dx.doi.org/10.3109/01902149209020653

49. Pauluhn J. Subchronic 13-week inhalation exposure of rats to multiwalled carbon nanotubes: Toxic effects are determined by density of agglomerate structures, not fibrillar structures. Toxicol Sci. 2009; 113(1):226-242. http://dx.doi.org/10.1093/toxsci/kfp247

50. Sturm R. A stochastic model of carbon nanotube deposition in the airways and alveoli of the human respiratory tract. Inhal Toxicol. 2016; 28(2):49-60. http://dx.doi.org/10.3109/08958378.2015.1136009

51. Mitchell LA, Gao J, Wal RV, Gigliotti A, Burchiel SW, McDonald JD. Pulmonary and systemic immune response to inhaled multiwalled carbon nanotubes. Toxicol Sci. 2007; 100(1):203-214. http://dx.doi.org/10.1093/toxsci/kfm196

52. Ma-Hock L, Treumann S, Strauss V, Brill S, Luizi F, Mertler M, Wiench K, Gamer AO, Van Ravenzwaay B, Landsiedel R. Inhalation toxicity of multiwall carbon nanotubes in rats exposed for 3 months. Toxicol Sci. 2009; 112(2):468-481. http://dx.doi.org/10.1093/toxsci/kfp146

53. Ellinger-Ziegelbauer H, Pauluhn J. Pulmonary toxicity of multi-walled carbon nanotubes (Baytubes ${ }^{\circledR}$ ) relative to $\alpha$-quartz following a single $6 \mathrm{~h}$ inhalation exposure of rats and a 3 months post-exposure period. Toxicology. 2009; 266(1-3):16-29. http://dx.doi.org/10.1016/j.tox.2009.10.007

54. Pauluhn J. Comparative pulmonary response to inhaled nanostructures: Considerations on test design and endpoints. Inhal Toxicol. 2009; 21(sup1):40-54.

55. Pothmann D, Simar S, Schuler D, Dony E, Gaering S, Le Net J-L, Okazaki Y, Chabagno JM, Bessibes C, Beausoleil J. Lung inflammation and lack of genotoxicity in the comet and micronucleus assays of industrial multiwalled carbon nanotubes Graphistrength $\odot \mathrm{C} 100$ after a 90-day nose-only inhalation exposure of rats. Part Fibre Toxicol. 2015; 12(1):21. http://dx.doi.org/10.1186/s12989-015-0096-2

56. Kasai T, Umeda Y, Ohnishi M, Kondo H, Takeuchi T, Aiso S, Nishizawa T, Matsumoto M, Fukushima S. Thirteen-week study of toxicity of fiber-like multi-walled carbon nanotubes with whole-body inhalation exposure in rats. Nanotoxicology. 2015; 9(4):413422. http://dx.doi.org/10.3109/17435390.2014.933903

57. Shvedova AA, Kisin ER, Mercer R, Murray AR, Johnson VJ, Potapovich AI, Tyurina YY, Gorelik O, Arepalli S, Schwegler-Berry D. Unusual inflammatory and fibrogenic 
pulmonary responses to single-walled carbon nanotubes in mice. Am J Physiol Lung Cell Mol Physiol. 2005; 289(5):L698-L708. http://dx.doi.org/10.1152/ajplung.00084.2005

58. Madl AK, Pinkerton KE. Health effects of inhaled engineered and incidental nanoparticles. Crit Rev Toxicol. 2009; 39(8):629-658. http://dx.doi.org/10.1080/10408440903133788

59. Baisch BL, Corson NM, Wade-Mercer P, Gelein R, Kennell AJ, Oberdörster G, Elder A. Equivalent titanium dioxide nanoparticle deposition by intratracheal instillation and whole body inhalation: The effect of dose rate on acute respiratory tract inflammation. Part Fibre Toxicol. 2014; 11(1):5. http://dx.doi.org/10.1186/1743-8977-11-5

60. Silva RM, Doudrick K, Franzi LM, TeeSy C, Anderson DS, Wu Z, Mitra S, Vu V, Dutrow G, Evans JE. Instillation versus inhalation of multiwalled carbon nanotubes: Exposurerelated health effects, clearance, and the role of particle characteristics. ACS Nano. 2014; 8(9):8911-8931. http://dx.doi.org/10.1021/nn503887r

61. Landsiedel R, Sauer UG, Ma-Hock L, Schnekenburger J, Wiemann M. Pulmonary toxicity of nanomaterials: A critical comparison of published in vitro assays and in vivo inhalation or instillation studies. Nanomedicine. 2014; 9(16):2557-2585. http://dx.doi.org/10.2217/nnm.14.149

62. Fatkhutdinova LM, Khaliullin TO, Vasil'yeva OL, Zalyalov RR, Mustafin IG, Kisin ER, Birch ME, Yanamala N, Shvedova AA. Fibrosis biomarkers in workers exposed to MWCNTs. Toxicol Appl Pharmacol. 2016; 299:125-131. http://dx.doi.org/10.1016/j.taap.2016.02.016

63. Shvedova AA, Yanamala N, Kisin ER, Khailullin TO, Birch ME, Fatkhutdinova LM. Integrated analysis of dysregulated ncRNA and mRNA expression profiles in humans exposed to carbon nanotubes. PLoS One. 2016; 11(3):e0150628. http://dx.doi.org/10.1371/journal.pone.0150628

64. Lee JS, Choi YC, Shin JH, Lee JH, Lee Y, Park SY, Baek JE, Park JD, Ahn K, Yu IJ. Health surveillance study of workers who manufacture multi-walled carbon nanotubes. Nanotoxicology. 2015; 9(6):802-811. http://dx.doi.org/10.3109/17435390.2014.978404

65. Kasai T, Umeda Y, Ohnishi M, Mine T, Kondo H, Takeuchi T, Matsumoto M, Fukushima S. Lung carcinogenicity of inhaled multi-walled carbon nanotube in rats. Part Fibre Toxicol. 2015; 13(1):53. http://dx.doi.org/10.1186/s12989-016-0164-2

66. Sargent LM, Porter DW, Staska LM, Hubbs AF, Lowry DT, Battelli L, Siegrist KJ, Kashon ML, Mercer RR, Bauer AK. Promotion of lung adenocarcinoma following inhalation exposure to multi-walled carbon nanotubes. Part Fibre Toxicol. 2014; 11(1):3. http://dx.doi.org/10.1186/1743-8977-11-3

67. Grosse Y, Loomis D, Guyton KZ, Lauby-Secretan B, El Ghissassi F, Bouvard V, Benbrahim-Tallaa L, Guha N, Scoccianti C, Mattock H. Carcinogenicity of fluoroedenite, silicon carbide fibres and whiskers, and carbon nanotubes. Lancet Oncol. 2014; 15(13):1427-1428. http://dx.doi.org/10.1016/S1470-2045(14)71109-X

68. Sakamoto Y, Nakae D, Fukumori N, Tayama K, Maekawa A, Imai K, Hirose A, Nishimura T, Ohashi N, Ogata A. Induction of mesothelioma by a single intrascrotal administration of multi-wall carbon nanotube in intact male Fischer 344 rats. J Toxicol Sci. 2009; 34(1):65-76. http://dx.doi.org/10.2131/jts.34.65

69. Takagi A, Hirose A, Nishimura T, Fukumori N, Ogata A, Ohashi N, Kitajima S, Kanno J. Induction of mesothelioma in p53+/- mouse by intraperitoneal application of multi-wall carbon nanotube. J Toxicol Sci. 2008; 33(1):105-116. http://dx.doi.org/10.2131/jts.33.105 
70. Takagi A, Hirose A, Futakuchi M, Tsuda H, Kanno J. Dose-dependent mesothelioma induction by intraperitoneal administration of multi-wall carbon nanotubes in p53 heterozygous mice. Cancer Sci. 2012; 103(8):1440-1444. http://dx.doi.org/10.1111/j.1349-7006.2012.02318.x

71. Nagai H, Okazaki Y, Chew SH, Misawa N, Yamashita Y, Akatsuka S, Ishihara T, Yamashita K, Yoshikawa Y, Yasui H. Diameter and rigidity of multiwalled carbon nanotubes are critical factors in mesothelial injury and carcinogenesis. Proc Natl Acad Sci. 2011; 108(49):E1330-E1338. http://dx.doi.org/10.1073/pnas.1110013108

72. Rittinghausen S, Hackbarth A, Creutzenberg O, Ernst H, Heinrich U, Leonhardt A, Schaudien D. The carcinogenic effect of various multi-walled carbon nanotubes (MWCNTs) after intraperitoneal injection in rats. Part Fibre Toxicol. 2014; 11(1):59. http://dx.doi.org/10.1186/s12989-014-0059-z

73. International Agency for Research on Cancer (IARC). IARC monographs on the evaluation of the carcinogenic risks to humans: Some nanomaterials and some fibres. Vol 111. Lyon, France: IARC; 2017.

74. Magdolenova Z, Collins A, Kumar A, Dhawan A, Stone V, Dusinska M. Mechanisms of genotoxicity. A review of in vitro and in vivo studies with engineered nanoparticles. Nanotoxicology. 2014; 8(3):233-278. http://dx.doi.org/10.3109/17435390.2013.773464

75. Kuempel ED, Jaurand M-C, Møller P, Morimoto Y, Kobayashi N, Pinkerton KE, Sargent LM, Vermeulen RCH, Fubini B, Kane AB. Evaluating the mechanistic evidence and key data gaps in assessing the potential carcinogenicity of carbon nanotubes and nanofibers in humans. Crit Rev Toxicol. 2017; 47(1):1-58. http://dx.doi.org/10.1080/10408444.2016.1206061

76. Møller P, Jacobsen NR. Weight of evidence analysis for assessing the genotoxic potential of carbon nanotubes. Crit Rev Toxicol. 2017; 47(10):871-888. http://dx.doi.org/10.1080/10408444.2017.1367755

77. Kim JS, Sung JH, Song KS, Lee JH, Kim SM, Lee GH, Ahn KH, Lee JS, Shin JH, Park JD. Persistent DNA damage measured by comet assay of Sprague Dawley rat lung cells after five days of inhalation exposure and 1 month post-exposure to dispersed multi-wall carbon nanotubes (MWCNTs) generated by new MWCNT aerosol generation system. Toxicol Sci. 2012; 128(2):439-448. http://dx.doi.org/10.1093/toxsci/kfs161

78. Kim JS, Sung JH, Choi BG, Ryu HY, Song KS, Shin JH, Lee JS, Hwang JH, Lee JH, Lee $\mathrm{GH}$. In vivo genotoxicity evaluation of lung cells from Fischer 344 rats following 28 days of inhalation exposure to MWCNTs, plus 28 days and 90 days post-exposure. Inhal Toxicol. 2014; 26(4):222-234. http://dx.doi.org/10.3109/08958378.2013.878006

79. Visalli G, Bertuccio MP, Iannazzo D, Piperno A, Pistone A, Di Pietro A. Toxicological assessment of multi-walled carbon nanotubes on A549 human lung epithelial cells. Toxicol In Vitro. 2015; 29(2):352-362. http://dx.doi.org/10.1016/j.tiv.2014.12.004

80. Muller J, Huaux F, Moreau N, Misson P, Heilier J-F, Delos M, Arras M, Fonseca A, Nagy JB, Lison D. Respiratory toxicity of multi-wall carbon nanotubes. Toxicol Appl Pharmacol. 2005; 207(3):221-231. http://dx.doi.org/10.1016/j.taap.2005.01.008

81. Smart SK, Cassady AI, Lu GQ, Martin DJ. The biocompatibility of carbon nanotubes. Carbon. 2006; 44(6):1034-1047. http://dx.doi.org/10.1016/j.carbon.2005.10.011

82. Levine KE, Han L, McWilliams AC, Essader AS, Amato KE, Fernando RA, Browning DB, Greene LC, Ensor DS, Walker NJ. Characterization of an assortment of commercially 
available multiwalled carbon nanotubes. Microchimica Acta. 2014; 181(1-2):171-179. http://dx.doi.org/10.1007/s00604-013-1088-2

83. Datsyuk V, Kalyva M, Papagelis K, Parthenios J, Tasis D, Siokou A, Kallitsis I, Galiotis C. Chemical oxidation of multiwalled carbon nanotubes. Carbon. 2008; 46(6):833-840. http://dx.doi.org/10.1016/j.carbon.2008.02.012

84. Stobinski L, Lesiak B, Kövér L, Tóth J, Biniak S, Trykowski G, Judek J. Multiwall carbon nanotubes purification and oxidation by nitric acid studied by the FTIR and electron spectroscopy methods. J Alloys Compd. 2010; 501(1):77-84. http://dx.doi.org/10.1016/j.jallcom.2010.04.032

85. Vaisman L, Marom G, Wagner HD. Dispersions of surface-modified carbon nanotubes in water-soluble and water-insoluble polymers. Adv Funct Mater. 2006; 16(3):357-363. http://dx.doi.org/10.1002/adfm.200500142

86. Hill MA, Watson CR, Moss OR. NEWCAS: An interactive computer program for particle size analysis. Richland, WA: Pacific Northwest Laboratory; 1977. PNL-2405, UC-32.

87. Maronpot RR, Boorman GA. Interpretation of rodent hepatocellular proliferative alterations and hepatocellular tumors in chemical safety assessment. Toxicol Pathol. 1982; 10(2):7178. http://dx.doi.org/10.1177/019262338201000210

88. Boorman GA, Montgomery CA, Jr., Eustis SL, Wolfe MJ, McConnell EE, Hardisty JF. Quality assurance in pathology for rodent carcinogenicity studies In: Milman HA, Weisburger EK, editors. Handbook of Carcinogen Testing. Park Ridge, NJ: Noyer Publications; 1985. p. 345-357.

89. Gart JJ, Chu KC, Tarone RE. Statistical issues in interpretation of chronic bioassay tests for carcinogenicity. J Natl Cancer Inst. 1979; 62(4):957-974.

90. Dunnett CW. A multiple comparison procedure for comparing several treatments with a control. J Am Stat Assoc. 1955; 50(272):1096-1121. http://dx.doi.org/10.1080/01621459.1955.10501294

91. Williams DA. A test for differences between treatment means when several dose levels are compared with a zero dose control. Biometrics. 1971:103-117. http://dx.doi.org/10.2307/2528930

92. Williams DA. The comparison of several dose levels with a zero dose control. Biometrics. 1972:519-531. http://dx.doi.org/10.2307/2556164

93. Shirley E. A non-parametric equivalent of Williams' test for contrasting increasing dose levels of a treatment. Biometrics. 1977; 33:386-389. http://dx.doi.org/10.2307/2529789

94. Williams DA. A note on Shirley's nonparametric test for comparing several dose levels with a zero-dose control. Biometrics. 1986:183-186. http://dx.doi.org/10.2307/2531254

95. Dunn OJ. Multiple comparisons using rank sums. Technometrics. 1964; 6(3):241-252. http://dx.doi.org/10.1080/00401706.1964.10490181

96. Jonckheere AR. A distribution-free k-sample test against ordered alternatives. Biometrika. 1954; 41(1/2):133-145. http://dx.doi.org/10.2307/2333011

97. Dixon WJ, Massey FJ, Jr. Introduction to statistical analysis. 2nd ed. New York, NY: McGraw-Hill Book Company, Inc; 1957. p. 276-278, 412.

98. Code of Federal Regulations (CFR). 21:Part 58.

99. Snyder-Talkington BN, Dong C, Porter DW, Ducatman B, Wolfarth MG, Andrew M, Battelli L, Raese R, Castranova V, Guo NL. Multiwalled carbon nanotube-induced pulmonary inflammatory and fibrotic responses and genomic changes following aspiration exposure 
in mice: A 1-year postexposure study. J Toxicol Environ Health, A. 2016; 79(8):352-366. http://dx.doi.org/10.1080/15287394.2016.1159635

100. International Agency for Research on Cancer (IARC). IARC monographs on the evaluation of the carcinogenic risks to humans: Arsenic, metals, fibres, and dusts. Vol 100c. Lyon, France: IARC; 2012.

101. Donaldson K, Poland CA, Murphy FA, MacFarlane M, Chernova T, Schinwald A. Pulmonary toxicity of carbon nanotubes and asbestos-similarities and differences. Adv Drug Del Rev. 2013; 65(15):2078-2086. http://dx.doi.org/10.1016/j.addr.2013.07.014

102. Hubbs AF, Mercer RR, Benkovic SA, Harkema J, Sriram K, Schwegler-Berry D, Goravanahally MP, Nurkiewicz TR, Castranova V, Sargent LM. Nanotoxicology-- A pathologist's perspective. Toxicol Pathol. 2011; 39(2):301-324. http://dx.doi.org/10.1177/0192623310390705

103. Ji JH, Jung JH, Kim SS, Yoon J-U, Park JD, Choi BS, Chung YH, Kwon IH, Jeong J, Han BS. Twenty-eight-day inhalation toxicity study of silver nanoparticles in Sprague-Dawley rats. Inhal Toxicol. 2007; 19(10):857-871. http://dx.doi.org/10.1080/08958370701432108

104. Warheit DB, Webb TR, Reed KL, Frerichs S, Sayes CM. Pulmonary toxicity study in rats with three forms of ultrafine-TiO2 particles: Differential responses related to surface properties. Toxicology. 2007; 230(1):90-104. http://dx.doi.org/10.1016/j.tox.2006.11.002

105. Warheit DB, Webb TR, Colvin VL, Reed KL, Sayes CM. Pulmonary bioassay studies with nanoscale and fine-quartz particles in rats: Toxicity is not dependent upon particle size but on surface characteristics. Toxicol Sci. 2006; 95(1):270-280. http://dx.doi.org/10.1093/toxsci/kfl128

106. Yang W, Peters JI, Williams Iii RO. Inhaled nanoparticles-a current review. Int J Pharm. 2008; 356(1-2):239-247. http://dx.doi.org/10.1016/j.ijpharm.2008.02.011

107. Pauluhn J. Poorly soluble particulates: Searching for a unifying denominator of nanoparticles and fine particles for DNEL estimation. Toxicology. 2011; 279(1-3):176188. http://dx.doi.org/10.1016/j.tox.2010.10.009

108. Sung JH, Ji JH, Park JD, Yoon JU, Kim DS, Jeon KS, Song MY, Jeong J, Han BS, Han JH. Subchronic inhalation toxicity of silver nanoparticles. Toxicol Sci. 2008; 108(2):452-461. http://dx.doi.org/10.1093/toxsci/kfn246

109. Braakhuis HM, Park MVDZ, Gosens I, De Jong WH, Cassee FR. Physicochemical characteristics of nanomaterials that affect pulmonary inflammation. Part Fibre Toxicol. 2014; 11(1):18. http://dx.doi.org/10.1186/1743-8977-11-18

110. Meunier E, Coste A, Olagnier D, Authier H, Lefèvre L, Dardenne C, Bernad J, Béraud M, Flahaut E, Pipy B. Double-walled carbon nanotubes trigger IL-1 $\beta$ release in human monocytes through Nlrp3 inflammasome activation. Nanomed Nanotechnol Biol Med. 2012; 8(6):987-995. http://dx.doi.org/10.1016/j.nano.2011.11.004

111. Pulskamp K, Diabaté S, Krug HF. Carbon nanotubes show no sign of acute toxicity but induce intracellular reactive oxygen species in dependence on contaminants. Toxicol Lett. 2007; 168(1):58-74. http://dx.doi.org/10.1016/j.toxlet.2006.11.001

112. Ye S, Wang Y, Jiao F, Zhang H, Lin C, Wu Y, Zhang Q. The role of NADPH oxidase in multi-walled carbon nanotubes-induced oxidative stress and cytotoxicity in human macrophages. J Nanosci Nanotechnol. 2011; 11(5):3773-3781. http://dx.doi.org/10.1166/jnn.2011.3862

113. Inoue K-i, Takano H, Koike E, Yanagisawa R, Sakurai M, Tasaka S, Ishizaka A, Shimada A. Effects of pulmonary exposure to carbon nanotubes on lung and systemic 
inflammation with coagulatory disturbance induced by lipopolysaccharide in mice. Exp Biol Med. 2008; 233(12):1583-1590. http://dx.doi.org/10.3181/0805-RM-179

114. Crouzier D, Follot S, Gentilhomme E, Flahaut E, Arnaud R, Dabouis V, Castellarin C, Debouzy J-C. Carbon nanotubes induce inflammation but decrease the production of reactive oxygen species in lung. Toxicology. 2010; 272(1-3):39-45. http://dx.doi.org/10.1016/j.tox.2010.04.001

115. Shvedova AA, Pietroiusti A, Fadeel B, Kagan VE. Mechanisms of carbon nanotubeinduced toxicity: Focus on oxidative stress. Toxicol Appl Pharmacol. 2012; 261(2):121133. http://dx.doi.org/10.1016/j.taap.2012.03.023

116. Dong J, Ma Q. Suppression of basal and carbon nanotube-induced oxidative stress, inflammation and fibrosis in mouse lungs by Nrf2. Nanotoxicology. 2016; 10(6):699709. http://dx.doi.org/10.3109/17435390.2015.1110758

117. Gaté L, Knudsen KB, Seidel C, Berthing T, Chézeau L, Jacobsen NR, Valentino S, Wallin $\mathrm{H}$, Bau S, Wolff H. Pulmonary toxicity of two different multi-walled carbon nanotubes in rat: Comparison between intratracheal instillation and inhalation exposure. Toxicol Appl Pharmacol. 2019; 375:17-31. http://dx.doi.org/10.1016/j.taap.2019.05.001

118. El-Gazzar AM, Abdelgied M, Alexander DB, Alexander WT, Numano T, Iigo M, Naiki A, Takahashi S, Takase H, Hirose A et al. Comparative pulmonary toxicity of a DWCNT and MWCNT-7 in rats. Arch Toxicol. 2019; 93(1):49-59. http://dx.doi.org/10.1007/s00204-018-2336-3

119. Bhattacharya K, Mukherjee SP, Gallud A, Burkert SC, Bistarelli S, Bellucci S, Bottini M, Star A, Fadeel B. Biological interactions of carbon-based nanomaterials: From coronation to degradation. Nanomed Nanotechnol Biol Med. 2016; 12(2):333-351. http://dx.doi.org/10.1016/j.nano.2015.11.011

120. Sayan M, Mossman BT. The NLRP3 inflammasome in pathogenic particle and fibreassociated lung inflammation and diseases. Part Fibre Toxicol. 2015; 13(1):51. http://dx.doi.org/10.1186/s12989-016-0162-4

121. Jessop F, Hamilton Jr RF, Rhoderick JF, Fletcher P, Holian A. Phagolysosome acidification is required for silica and engineered nanoparticle-induced lysosome membrane permeabilization and resultant NLRP3 inflammasome activity. Toxicol Appl Pharmacol. 2017; 318:58-68. http://dx.doi.org/10.1016/j.taap.2017.01.012

122. Knudsen KB, Berthing T, Jackson P, Poulsen SS, Mortensen A, Jacobsen NR, Skaug V, Szarek J, Hougaard KS, Wolff $\mathrm{H}$ et al. Physicochemical predictors of Multi-Walled Carbon Nanotube-induced pulmonary histopathology and toxicity one year after pulmonary deposition of 11 different Multi-Walled Carbon Nanotubes in mice. Basic Clin Pharmacol Toxicol. 2019; 124(2):211-227. http://dx.doi.org/10.1111/bcpt.13119

123. Cesta MF, Herbert RA, Brix A, Malarkey DE, Sills RC. Lung, epithelium, alveolus hyperplasia In: National Toxicology Program Nonneoplastic Lesion Atlas. U.S. Department of Health and Human Services, Public Health Service, National Toxicology Program; 2015. https://ntp.niehs.nih.gov/nnl/respiratory/lung/epivhyp [Accessed: April 4, 2018]

124. Owen K. Regulatory toxicology considerations for the development of inhaled pharmaceuticals. Drug Chem Toxicol. 2013; 36(1):109-118. http://dx.doi.org/10.3109/01480545.2011.648327

125. Buckley LA, Morgan KT, Swenberg JA, James RA, Hamm Jr TE, Barrow CS. The toxicity of dimethylamine in F-344 rats and B6C3F1 mice following a 1-year inhalation exposure. 
Fundam Appl Toxicol. 1985; 5(2):341-352. http://dx.doi.org/10.1016/02720590(85)90082-X

126. Gopinath C, Prentice DE, Lewis DJ. The respiratory system. In: Atlas of Experimental Toxicological Pathology. Netherlands: Springer; 1987. p. 22-42. http://dx.doi.org/10.1007/978-94-009-3189-3_3

127. Lewis DJ. Morphological assessment of pathological changes within the rat larynx. Toxicol Pathol. 1991; 19(4 Pt 1):352-357. http://dx.doi.org/10.1177/0192623391019004-104

128. Miller RA, Renne RA. Effects of xenobiotics on the larynx of the rat, mouse, and hamster In: Jones TC, Dungworth DL, Mohr U, editors. Respiratory System. 2nd ed. Berlin, Germany: Springer-Verlag; 1996. p. 51-57. http://dx.doi.org/10.1007/978-3-642-61042$\underline{4} 5$

129. Kaufmann W, Bader R, Ernst H, Harada T, Hardisty J, Kittel B, Kolling A, Pino M, Renne R, Rittinghausen S. 1st international ESTP expert workshop: "Larynx squamous metaplasia". A re-consideration of morphology and diagnostic approaches in rodent studies and its relevance for human risk assessment. Exp Toxicol Pathol. 2009; 61(6):591-603. http://dx.doi.org/10.1016/j.etp.2009.01.001

130. Renne RA, Gideon KM. Types and patterns of response in the larynx following inhalation. Toxicol Pathol. 2006; 34(3):281-285. http://dx.doi.org/10.1080/01926230600695631

131. Renne RA, Gideon KM, Harbo SJ, Staska LM, Grumbein SL. Upper respiratory tract lesions in inhalation toxicology. Toxicol Pathol. 2007; 35(1):163-169. http://dx.doi.org/10.1080/01926230601052667

132. Burger GT, Renne RA, Sagartz JW, Ayres PH, Coggins CRE, Mosberg AT, Hayes AW. Histologic changes in the respiratory tract induced by inhalation of xenobiotics: Physiologic adaptation or toxicity? Toxicol Appl Pharmacol. 1989; 101(3):521-542. http://dx.doi.org/10.1016/0041-008X(89)90200-7

133. Takahashi H, Sano H, Chiba H, Kuroki Y. Pulmonary surfactant proteins A and D: Innate immune functions and biomarkers for lung diseases. Curr Pharm Des. 2006; 12(5):589598. http://dx.doi.org/10.2174/138161206775474387

134. Kitamura T, Tanaka N, Watanabe J, Kanegasaki S, Yamada Y, Nakata K. Idiopathic pulmonary alveolar proteinosis as an autoimmune disease with neutralizing antibody against granulocyte/macrophage colony-stimulating factor. J Exp Med. 1999; 190(6):875880. http://dx.doi.org/10.1084/jem.190.6.875

135. Martinez-Moczygemba M, Doan ML, Elidemir O, Fan LL, Cheung SW, Lei JT, Moore JP, Tavana G, Lewis LR, Zhu Y. Pulmonary alveolar proteinosis caused by deletion of the GM-CSFR $\alpha$ gene in the X chromosome pseudoautosomal region 1. J Exp Med. 2008; 205(12):2711-2716. http://dx.doi.org/10.1084/jem.20080759

136. Suzuki T, Sakagami T, Rubin BK, Nogee LM, Wood RE, Zimmerman SL, Smolarek T, Dishop MK, Wert SE, Whitsett JA. Familial pulmonary alveolar proteinosis caused by mutations in CSF2RA. J Exp Med. 2008; 205(12):2703-2710. http://dx.doi.org/10.1084/jem.20080990

137. Carey B, Trapnell BC. The molecular basis of pulmonary alveolar proteinosis. Clin Immunol. 2010; 135(2):223-235. http://dx.doi.org/10.1016/j.clim.2010.02.017

138. Rosen SH, Castleman B, Liebow AA, Enzinger FM, Hunt RTN. Pulmonary alveolar proteinosis. N Engl J Med. 1958; 258(23):1123-1142.

http://dx.doi.org/10.1056/NEJM195806052582301 
139. Davidson JM, Macleod WM. Pulmonary alveolar proteinosis. Br J Dis Chest. 1969; 63(1):13-28.

140. Xipell JM, Ham KN, Price CG, Thomas DP. Acute silicoproteinosis. Thorax. 1977; 32(1):104-111. http://dx.doi.org/10.1136/thx.32.1.104

141. Miller RR, Churg AM, Hutcheon M, Lam S. Pulmonary alveolar proteinosis and aluminum dust exposure. Am Rev Respir Dis. 1984; 130(2):312-315. http://dx.doi.org/10.1164/arrd.1984.130.2.312

142. McCunney RJ, Godefroi R. Pulmonary alveolar proteinosis and cement dust: A case report. J Occup Med. 1989; 31(3):233-237. http://dx.doi.org/10.1097/00043764-198903000$\underline{00008}$

143. Dawkins SA, Gerhard H, Nevin M. Pulmonary alveolar proteinosis: A possible sequel of NO2 exposure. J Occup Med. 1991; 33(5):638-641. http://dx.doi.org/10.1097/00007611199109001-00015

144. Keller CA, Frost A, Cagle PT, Abraham JL. Pulmonary alveolar proteinosis in a painter with elevated pulmonary concentrations of titanium. Chest. 1995; 108(1):277-280. http://dx.doi.org/10.1378/chest.108.1.277

145. McDonald JW, Alvarez F, Keller CA. Pulmonary alveolar proteinosis in association with household exposure to fibrous insulation material. Chest. 2000; 117(6):1813-1817. http://dx.doi.org/10.1378/chest.117.6.1813

146. Humble S, Allan Tucker J, Boudreaux C, King JAC, Snell K. Titanium particles identified by energy-dispersive X-ray microanalysis within the lungs of a painter at autopsy. Ultrastruct Pathol. 2003; 27(2):127-129. http://dx.doi.org/10.1080/01913120309925

147. Khan A, Agarwal R. Pulmonary alveolar proteinosis. Respir Care. 2011; 56(7):1016-1028. http://dx.doi.org/10.4187/respcare.01125

148. Snipes MB. Pulmonary retention of particles and fibers In: McClellan RO, Henderson RF, editors. Concepts in Inhalation Toxicology. 2nd ed. Boca Raton, FL: CRC Press; 1995. p. 225-256. http://dx.doi.org/10.1201/b14404-14

149. Miller FJ. Dosimetry of particles in laboratory animals and humans in relationship to issues surrounding lung overload and human health risk assessment: A critical review. Inhal Toxicol. 2000; 12(1):19-57. http://dx.doi.org/10.1080/089583700196536

150. Cullen RT, Tran CL, Buchanan D, Davis JMG, Searl A, Jones AD, Donaldson K. Inhalation of poorly soluble particles. I. Differences in inflammatory response and clearance during exposure. Inhal Toxicol. 2000; 12(12):1089-1111. http://dx.doi.org/10.1080/08958370050166787

151. Morrow PE. Possible mechanisms to explain dust overloading of the lungs. Toxicol Sci. 1988; 10(3):369-384. http://dx.doi.org/10.1016/0272-0590(88)90284-9

152. Tran CL, Buchanan D, Cullen RT, Searl A, Jones AD, Donaldson K. Inhalation of poorly soluble particles. II. Influence of particle surface area on inflammation and clearance. Inhal Toxicol. 2000; 12(12):1113-1126. http://dx.doi.org/10.1080/08958370050166796

153. Dahm MM, Schubauer-Berigan MK, Evans DE, Birch ME, Bertke S, Beard JD, Erdely A, Fernback JE, Mercer RR, Grinshpun SA. Exposure assessments for a cross-sectional epidemiologic study of US carbon nanotube and nanofiber workers. Int J Hyg Environ Health. 2018; 221(3):429-440. https://doi.org/10.1016/j.ijheh.2018.01.006 


\section{Appendix A. Summary of Nonneoplastic Lesions in Rats and Mice}

\section{Tables}

Table A-1. Summary of the Incidence of Nonneoplastic Lesions in Male Rats in the 30day Inhalation Study of 1020 Long Multiwalled Carbon Nanotubes

Table A-2. Summary of the Incidence of Nonneoplastic Lesions in Female Rats in the 30day Inhalation Study of 1020 Long Multiwalled Carbon Nanotubes

Table A-3. Summary of the Incidence of Nonneoplastic Lesions in Male Mice in the 30day Inhalation Study of 1020 Long Multiwalled Carbon Nanotubes A-6

Table A-4. Summary of the Incidence of Nonneoplastic Lesions in Female Mice in the 30-day Inhalation Study of 1020 Long Multiwalled Carbon Nanotubes 
Table A-1. Summary of the Incidence of Nonneoplastic Lesions in Male Rats in the 30-day Inhalation Study of 1020 Long Multiwalled Carbon Nanotubes ${ }^{a}$

\begin{tabular}{|c|c|c|c|c|c|c|}
\hline & $\begin{array}{c}\text { Chamber } \\
\text { Control }\end{array}$ & $0.1 \mathrm{mg} / \mathrm{m}^{3}$ & $0.3 \mathrm{mg} / \mathrm{m}^{3}$ & $1 \mathrm{mg} / \mathrm{m}^{3}$ & $3 \mathrm{mg} / \mathrm{m}^{3}$ & $10 \mathrm{mg} / \mathrm{m}^{3}$ \\
\hline \multicolumn{7}{|l|}{ Disposition Summary } \\
\hline Animals Initially in Study & 35 & 35 & 35 & 35 & 35 & 35 \\
\hline \multicolumn{7}{|l|}{ Survivors } \\
\hline Terminal Euthanasia & 10 & 10 & 10 & 10 & 10 & 10 \\
\hline Lung Burden Study & 25 & 25 & 25 & 25 & 25 & 25 \\
\hline Animals Examined Microscopically & 10 & 10 & 10 & 10 & 10 & 10 \\
\hline \multicolumn{7}{|l|}{ Alimentary System } \\
\hline Liver & $(0)$ & (1) & $(0)$ & $(0)$ & $(0)$ & $(0)$ \\
\hline Necrosis, Focal & - & $1(100 \%)$ & - & - & - & - \\
\hline Pharynx & (10) & $(10)$ & (10) & $(10)$ & $(10)$ & $(10)$ \\
\hline \multicolumn{7}{|l|}{ Cardiovascular System } \\
\hline None & - & - & - & - & - & - \\
\hline \multicolumn{7}{|l|}{ Endocrine System } \\
\hline None & - & - & - & - & - & - \\
\hline \multicolumn{7}{|l|}{ General Body System } \\
\hline None & - & - & - & - & - & - \\
\hline \multicolumn{7}{|l|}{ Genital System } \\
\hline None & - & - & - & - & - & - \\
\hline \multicolumn{7}{|l|}{ Hematopoietic System } \\
\hline Lymph Node, Bronchial & (6) & (6) & (9) & (7) & (7) & (7) \\
\hline Foreign Body & - & - & - & $4(57 \%)$ & $6(86 \%)$ & $7(100 \%)$ \\
\hline Hyperplasia, Lymphoid & - & - & - & - & $6(86 \%)$ & $2(29 \%)$ \\
\hline Lymph Node, Mediastinal & (7) & (9) & (10) & (9) & (9) & $(10)$ \\
\hline Foreign Body & - & - & - & $3(33 \%)$ & $8(89 \%)$ & $10(100 \%)$ \\
\hline Hyperplasia, Lymphoid & - & $3(33 \%)$ & $1(10 \%)$ & $3(33 \%)$ & $8(89 \%)$ & $9(90 \%)$ \\
\hline \multicolumn{7}{|l|}{ Integumentary System } \\
\hline None & - & - & - & - & - & - \\
\hline \multicolumn{7}{|l|}{ Musculoskeletal System } \\
\hline None & - & - & - & - & - & - \\
\hline \multicolumn{7}{|l|}{ Nervous System } \\
\hline None & - & - & - & - & - & - \\
\hline \multicolumn{7}{|l|}{ Respiratory System } \\
\hline Larynx & (10) & (10) & (10) & (10) & (10) & (10) \\
\hline
\end{tabular}


L-MWNT-1020, NTP TOX 94

\begin{tabular}{|c|c|c|c|c|c|c|}
\hline & $\begin{array}{l}\text { Chamber } \\
\text { Control }\end{array}$ & $0.1 \mathrm{mg} / \mathrm{m}^{3}$ & $0.3 \mathrm{mg} / \mathrm{m}^{3}$ & $1 \mathrm{mg} / \mathrm{m}^{3}$ & $3 \mathrm{mg} / \mathrm{m}^{3}$ & $10 \mathrm{mg} / \mathrm{m}^{3}$ \\
\hline Epiglottis, Metaplasia, Squamous & - & - & - & $1(10 \%)$ & $9(90 \%)$ & $9(90 \%)$ \\
\hline Lung & $(10)$ & (10) & $(10)$ & (10) & (10) & $(10)$ \\
\hline Foreign Body & & $10(100 \%)$ & $10(100 \%)$ & $10(100 \%)$ & $10(100 \%)$ & $10(100 \%)$ \\
\hline Inflammation, Chronic & $5(50 \%)$ & $1(10 \%)$ & $2(20 \%)$ & $10(100 \%)$ & $10(100 \%)$ & $10(100 \%)$ \\
\hline Alveolar Epithelium, Hyperplasia & - & - & - & $3(30 \%)$ & $10(100 \%)$ & $10(100 \%)$ \\
\hline Nose & $(10)$ & (10) & $(10)$ & $(10)$ & $(10)$ & $(10)$ \\
\hline $\begin{array}{l}\text { Olfactory Epithelium, } \\
\text { Accumulation, Hyaline Droplet }\end{array}$ & - & $1(10 \%)$ & $3(30 \%)$ & - & - & $3(30 \%)$ \\
\hline $\begin{array}{l}\text { Respiratory Epithelium, } \\
\text { Accumulation, Hyaline Droplet }\end{array}$ & - & - & - & - & $1(10 \%)$ & $1(10 \%)$ \\
\hline Trachea & (9) & $(10)$ & (10) & $(10)$ & $(10)$ & $(10)$ \\
\hline \multicolumn{7}{|l|}{ Special Senses System } \\
\hline None & - & - & - & - & - & - \\
\hline \multicolumn{7}{|l|}{ Urinary System } \\
\hline None & - & - & - & - & - & - \\
\hline
\end{tabular}

${ }^{\mathrm{a}}$ Number of animals examined microscopically at the site and the number of animals with lesion. 
Table A-2. Summary of the Incidence of Nonneoplastic Lesions in Female Rats in the 30-day Inhalation Study of 1020 Long Multiwalled Carbon Nanotubes ${ }^{a}$

\begin{tabular}{|c|c|c|c|c|c|c|}
\hline & $\begin{array}{c}\text { Chamber } \\
\text { Control }\end{array}$ & $0.1 \mathrm{mg} / \mathrm{m}^{3}$ & $0.3 \mathrm{mg} / \mathrm{m}^{3}$ & $1 \mathrm{mg} / \mathrm{m}^{3}$ & $3 \mathrm{mg} / \mathrm{m}^{3}$ & $10 \mathrm{mg} / \mathrm{m}^{3}$ \\
\hline \multicolumn{7}{|l|}{ Disposition Summary } \\
\hline Animals Initially in Study & 35 & 35 & 35 & 35 & 35 & 35 \\
\hline \multicolumn{7}{|l|}{ Survivors } \\
\hline Terminal Euthanasia & 10 & 10 & 10 & 10 & 10 & 10 \\
\hline Lung Burden Study & 25 & 25 & 25 & 25 & 25 & 25 \\
\hline Animals Examined Microscopically & 10 & 10 & 10 & 10 & 10 & 10 \\
\hline \multicolumn{7}{|l|}{ Alimentary System } \\
\hline Pharynx & $(10)$ & $(10)$ & $(10)$ & $(10)$ & (10) & (10) \\
\hline \multicolumn{7}{|l|}{ Cardiovascular System } \\
\hline None & - & - & - & - & - & - \\
\hline \multicolumn{7}{|l|}{ Endocrine System } \\
\hline None & - & - & - & - & - & - \\
\hline \multicolumn{7}{|l|}{ General Body System } \\
\hline None & - & - & - & - & - & - \\
\hline \multicolumn{7}{|l|}{ Genital System } \\
\hline Uterus & $(0)$ & $(0)$ & $(0)$ & (1) & $(0)$ & (0) \\
\hline Endometrium, Hyperplasia, Cystic & - & - & - & $1(100 \%)$ & - & - \\
\hline \multicolumn{7}{|l|}{ Hematopoietic System } \\
\hline Lymph Node & $(0)$ & $(0)$ & $(0)$ & $(0)$ & $(0)$ & (1) \\
\hline Iliac, Pigmentation & - & - & - & - & - & $1(100 \%)$ \\
\hline Lymph Node, Bronchial & (7) & (6) & (4) & (6) & (7) & (9) \\
\hline Foreign Body & - & - & - & $4(67 \%)$ & $7(100 \%)$ & $9(100 \%)$ \\
\hline Hyperplasia, Lymphoid & - & $1(17 \%)$ & - & $2(33 \%)$ & $6(86 \%)$ & $7(78 \%)$ \\
\hline Lymph Node, Mediastinal & $(10)$ & $(10)$ & (9) & $(10)$ & $(10)$ & $(10)$ \\
\hline Foreign Body & - & $1(10 \%)$ & $1(11 \%)$ & $6(60 \%)$ & $10(100 \%)$ & $10(100 \%)$ \\
\hline Hyperplasia, Lymphoid & $2(20 \%)$ & $3(30 \%)$ & $3(33 \%)$ & $7(70 \%)$ & $9(90 \%)$ & $10(100 \%)$ \\
\hline Pigmentation & $1(10 \%)$ & - & - & - & - & - \\
\hline
\end{tabular}

Integumentary System

None

Musculoskeletal System

None

Nervous System

None 
L-MWNT-1020, NTP TOX 94

\begin{tabular}{|c|c|c|c|c|c|c|}
\hline & $\begin{array}{l}\text { Chamber } \\
\text { Control }\end{array}$ & $0.1 \mathrm{mg} / \mathrm{m}^{3}$ & $0.3 \mathrm{mg} / \mathrm{m}^{3}$ & $1 \mathrm{mg} / \mathrm{m}^{3}$ & $3 \mathrm{mg} / \mathrm{m}^{3}$ & $10 \mathrm{mg} / \mathrm{m}^{3}$ \\
\hline \multicolumn{7}{|l|}{ Respiratory System } \\
\hline Larynx & $(10)$ & $(10)$ & $(10)$ & $(10)$ & (10) & $(10)$ \\
\hline Epiglottis, Metaplasia, Squamous & - & $1(10 \%)$ & - & $6(60 \%)$ & $9(90 \%)$ & $7(70 \%)$ \\
\hline Lung & $(10)$ & $(10)$ & (10) & $(10)$ & (10) & (10) \\
\hline Foreign Body & - & $10(100 \%)$ & $10(100 \%)$ & $10(100 \%)$ & $10(100 \%)$ & $10(100 \%)$ \\
\hline Inflammation, Chronic & - & $3(30 \%)$ & $2(20 \%)$ & $6(60 \%)$ & $10(100 \%)$ & $10(100 \%)$ \\
\hline Alveolar Epithelium, Hyperplasia & - & - & - & $2(20 \%)$ & $10(100 \%)$ & $10(100 \%)$ \\
\hline Nose & $(10)$ & (10) & $(10)$ & $(10)$ & $(10)$ & $(10)$ \\
\hline $\begin{array}{l}\text { Olfactory Epithelium, } \\
\text { Accumulation, Hyaline Droplet }\end{array}$ & $1(10 \%)$ & - & $1(10 \%)$ & $1(10 \%)$ & - & $4(40 \%)$ \\
\hline $\begin{array}{l}\text { Respiratory Epithelium, } \\
\text { Accumulation, Hyaline Droplet }\end{array}$ & - & - & - & - & - & $1(10 \%)$ \\
\hline Trachea & (8) & (10) & (10) & (10) & (10) & (10) \\
\hline \multicolumn{7}{|l|}{ Special Senses System } \\
\hline None & - & - & - & - & - & - \\
\hline \multicolumn{7}{|l|}{ Urinary System } \\
\hline None & - & - & - & - & - & - \\
\hline
\end{tabular}

${ }^{\mathrm{a}}$ Number of animals examined microscopically at the site and the number of animals with lesion. 
Table A-3. Summary of the Incidence of Nonneoplastic Lesions in Male Mice in the 30-day Inhalation Study of 1020 Long Multiwalled Carbon Nanotubes ${ }^{a}$

\begin{tabular}{|c|c|c|c|c|c|c|}
\hline & $\begin{array}{l}\text { Chamber } \\
\text { Control }\end{array}$ & $0.1 \mathrm{mg} / \mathrm{m}^{3}$ & $0.3 \mathrm{mg} / \mathrm{m}^{3}$ & $1 \mathrm{mg} / \mathrm{m}^{3}$ & $3 \mathrm{mg} / \mathrm{m}^{3}$ & $10 \mathrm{mg} / \mathrm{m}^{3}$ \\
\hline \multicolumn{7}{|l|}{ Disposition Summary } \\
\hline Animals Initially in Study & 35 & 35 & 35 & 35 & 35 & 35 \\
\hline \multicolumn{7}{|l|}{ Survivors } \\
\hline Terminal Euthanasia & 10 & 10 & 10 & 10 & 10 & 10 \\
\hline Lung Burden Study & 25 & 25 & 25 & 25 & 25 & 25 \\
\hline Animals Examined Microscopically & 10 & 10 & 10 & 10 & 10 & 10 \\
\hline \multicolumn{7}{|l|}{ Alimentary System } \\
\hline Pharynx & $(10)$ & $(10)$ & $(10)$ & $(10)$ & $(10)$ & $(10)$ \\
\hline \multicolumn{7}{|l|}{ Cardiovascular System } \\
\hline None & - & - & - & - & - & - \\
\hline \multicolumn{7}{|l|}{ Endocrine System } \\
\hline None & - & - & - & - & - & - \\
\hline \multicolumn{7}{|l|}{ General Body System } \\
\hline None & - & - & - & - & - & - \\
\hline \multicolumn{7}{|l|}{ Genital System } \\
\hline None & - & - & - & - & - & - \\
\hline \multicolumn{7}{|l|}{ Hematopoietic System } \\
\hline Lymph Node & (0) & (1) & (0) & $(0)$ & (0) & $(0)$ \\
\hline Lumbar, Hyperplasia, Lymphoid & - & $1(100 \%)$ & - & - & - & - \\
\hline Lumbar, Pigmentation & - & $1(100 \%)$ & - & - & - & - \\
\hline Lymph Node, Bronchial & (6) & (9) & (7) & (7) & (9) & (7) \\
\hline Foreign Body & - & - & - & $5(71 \%)$ & $9(100 \%)$ & $6(86 \%)$ \\
\hline Hyperplasia, Lymphoid & - & - & - & $2(29 \%)$ & $5(56 \%)$ & $3(43 \%)$ \\
\hline Lymph Node, Mediastinal & (9) & (7) & $(8)$ & $(10)$ & (9) & (9) \\
\hline Foreign Body & - & - & $1(13 \%)$ & $2(20 \%)$ & $1(11 \%)$ & $3(33 \%)$ \\
\hline Hyperplasia, Lymphoid & - & - & - & $1(10 \%)$ & $1(11 \%)$ & $3(33 \%)$ \\
\hline \multicolumn{7}{|l|}{ Integumentary System } \\
\hline None & - & - & - & - & - & - \\
\hline \multicolumn{7}{|l|}{ Musculoskeletal System } \\
\hline None & - & - & - & - & - & - \\
\hline \multicolumn{7}{|l|}{ Nervous System } \\
\hline None & - & - & - & - & - & - \\
\hline
\end{tabular}


L-MWNT-1020, NTP TOX 94

\begin{tabular}{|c|c|c|c|c|c|c|}
\hline & $\begin{array}{l}\text { Chamber } \\
\text { Control }\end{array}$ & $0.1 \mathrm{mg} / \mathrm{m}^{3}$ & $0.3 \mathrm{mg} / \mathrm{m}^{3}$ & $1 \mathrm{mg} / \mathrm{m}^{3}$ & $3 \mathrm{mg} / \mathrm{m}^{3}$ & $10 \mathrm{mg} / \mathrm{m}^{3}$ \\
\hline \multicolumn{7}{|l|}{ Respiratory System } \\
\hline Larynx & (9) & $(10)$ & $(10)$ & $(10)$ & $(10)$ & $(10)$ \\
\hline Epiglottis, Metaplasia, Squamous & $1(11 \%)$ & $2(20 \%)$ & $3(30 \%)$ & $6(60 \%)$ & $9(90 \%)$ & $10(100 \%)$ \\
\hline Lung & $(10)$ & $(10)$ & $(10)$ & $(10)$ & $(10)$ & $(10)$ \\
\hline Foreign Body & - & $9(90 \%)$ & $10(100 \%)$ & $10(100 \%)$ & $10(100 \%)$ & $10(100 \%)$ \\
\hline Inflammation, Chronic & - & - & - & $8(80 \%)$ & $10(100 \%)$ & $10(100 \%)$ \\
\hline Alveolus, Proteinosis & - & - & - & - & $3(30 \%)$ & $10(100 \%)$ \\
\hline $\begin{array}{l}\text { Bronchiole, Epithelium, } \\
\text { Hyperplasia }\end{array}$ & - & - & - & - & $7(70 \%)$ & $10(100 \%)$ \\
\hline Nose & (10) & $(10)$ & $(10)$ & $(10)$ & $(10)$ & $(10)$ \\
\hline Inflammation, Suppurative & $1(10 \%)$ & - & - & - & - & - \\
\hline $\begin{array}{l}\text { Olfactory Epithelium, } \\
\text { Accumulation, Hyaline Droplet }\end{array}$ & - & - & - & - & $2(20 \%)$ & $9(90 \%)$ \\
\hline $\begin{array}{l}\text { Respiratory Epithelium, } \\
\text { Accumulation, Hyaline Droplet }\end{array}$ & - & - & - & $3(30 \%)$ & $9(90 \%)$ & $10(100 \%)$ \\
\hline Trachea & $(10)$ & (10) & $(10)$ & (8) & (10) & $(10)$ \\
\hline \multicolumn{7}{|l|}{ Special Senses System } \\
\hline None & - & - & - & - & - & - \\
\hline \multicolumn{7}{|l|}{ Urinary System } \\
\hline None & - & - & - & - & - & - \\
\hline
\end{tabular}

${ }^{a}$ Number of animals examined microscopically at the site and the number of animals with lesion. 
Table A-4. Summary of the Incidence of Nonneoplastic Lesions in Female Mice in the 30-day Inhalation Study of 1020 Long Multiwalled Carbon Nanotubes ${ }^{a}$

\begin{tabular}{|c|c|c|c|c|c|c|}
\hline & $\begin{array}{l}\text { Chamber } \\
\text { Control }\end{array}$ & $0.1 \mathrm{mg} / \mathrm{m}^{3}$ & $0.3 \mathrm{mg} / \mathrm{m}^{3}$ & $1 \mathrm{mg} / \mathrm{m}^{3}$ & $3 \mathrm{mg} / \mathrm{m3}$ & $10 \mathrm{mg} / \mathrm{m}^{3}$ \\
\hline \multicolumn{7}{|l|}{ Disposition Summary } \\
\hline Animals Initially in Study & 35 & 35 & 35 & 35 & 35 & 35 \\
\hline \multicolumn{7}{|l|}{ Survivors } \\
\hline Terminal Euthanasia & 10 & 10 & 10 & 10 & 10 & 10 \\
\hline Lung Burden Study & 25 & 25 & 25 & 25 & 25 & 25 \\
\hline Animals Examined Microscopically & 10 & 10 & 10 & 10 & 10 & 10 \\
\hline \multicolumn{7}{|l|}{ Alimentary System } \\
\hline Liver & (2) & $(0)$ & $(0)$ & $(0)$ & $(0)$ & $(0)$ \\
\hline Necrosis, Focal & $1(50 \%)$ & - & - & - & - & - \\
\hline Pharynx & $(10)$ & $(10)$ & $(10)$ & $(10)$ & $(10)$ & $(10)$ \\
\hline \multicolumn{7}{|l|}{ Cardiovascular System } \\
\hline None & - & - & - & - & - & - \\
\hline \multicolumn{7}{|l|}{ Endocrine System } \\
\hline None & - & - & - & - & - & - \\
\hline \multicolumn{7}{|l|}{ General Body System } \\
\hline None & - & - & - & - & - & - \\
\hline \multicolumn{7}{|l|}{ Genital System } \\
\hline None & - & - & - & - & - & - \\
\hline \multicolumn{7}{|l|}{ Hematopoietic System } \\
\hline Lymph Node & (1) & (1) & (2) & $(0)$ & (1) & (1) \\
\hline Lumbar, Pigmentation & $1(100 \%)$ & $1(100 \%)$ & $2(100 \%)$ & - & $1(100 \%)$ & $1(100 \%)$ \\
\hline Lymph Node, Bronchial & (9) & (3) & $(8)$ & (9) & (6) & $(6)$ \\
\hline Foreign Body & - & - & - & $3(33 \%)$ & $5(83 \%)$ & $5(83 \%)$ \\
\hline Hyperplasia, Lymphoid & $1(11 \%)$ & - & - & $2(22 \%)$ & $3(50 \%)$ & $5(83 \%)$ \\
\hline Lymph Node, Mediastinal & (7) & (8) & (8) & (7) & $(10)$ & (9) \\
\hline Foreign Body & - & - & - & - & $4(40 \%)$ & $7(78 \%)$ \\
\hline Hyperplasia, Lymphoid & - & - & - & $1(14 \%)$ & $1(10 \%)$ & $5(56 \%)$ \\
\hline \multicolumn{7}{|l|}{ Integumentary System } \\
\hline None & - & - & - & - & - & - \\
\hline \multicolumn{7}{|l|}{ Musculoskeletal System } \\
\hline None & - & - & - & - & - & - \\
\hline \multicolumn{7}{|l|}{ Nervous System } \\
\hline None & - & - & - & - & - & - \\
\hline
\end{tabular}


L-MWNT-1020, NTP TOX 94

\begin{tabular}{|c|c|c|c|c|c|c|}
\hline & $\begin{array}{l}\text { Chamber } \\
\text { Control }\end{array}$ & $0.1 \mathrm{mg} / \mathrm{m}^{3}$ & $0.3 \mathrm{mg} / \mathrm{m}^{3}$ & $1 \mathrm{mg} / \mathrm{m}^{3}$ & $3 \mathrm{mg} / \mathrm{m3}$ & $10 \mathrm{mg} / \mathrm{m}^{3}$ \\
\hline \multicolumn{7}{|l|}{ Respiratory System } \\
\hline Larynx & $(10)$ & (10) & $(10)$ & (10) & (10) & $(10)$ \\
\hline Epiglottis, Metaplasia, Squamous & $1(10 \%)$ & $1(10 \%)$ & $1(10 \%)$ & $4(40 \%)$ & $6(60 \%)$ & $10(100 \%)$ \\
\hline Lung & $(10)$ & (10) & $(10)$ & (10) & (10) & (10) \\
\hline Foreign Body & - & $9(90 \%)$ & $10(100 \%)$ & $10(100 \%)$ & $10(100 \%)$ & $10(100 \%)$ \\
\hline Inflammation, Chronic & - & - & - & $4(40 \%)$ & $10(100 \%)$ & $10(100 \%)$ \\
\hline Metaplasia, Osseous & - & $1(10 \%)$ & - & - & - & - \\
\hline Alveolus, Proteinosis & - & - & - & - & $9(90 \%)$ & $10(100 \%)$ \\
\hline Bronchiole, Epithelium, Hyperplasia & - & - & - & - & $6(60 \%)$ & $10(100 \%)$ \\
\hline Nose & $(10)$ & (10) & $(10)$ & $(10)$ & (10) & (10) \\
\hline $\begin{array}{l}\text { Olfactory Epithelium, } \\
\text { Accumulation, Hyaline Droplet }\end{array}$ & - & - & $1(10 \%)$ & $3(30 \%)$ & $8(80 \%)$ & $10(100 \%)$ \\
\hline $\begin{array}{l}\text { Respiratory Epithelium, } \\
\text { Accumulation, Hyaline Droplet }\end{array}$ & - & - & - & $8(80 \%)$ & $10(100 \%)$ & $10(100 \%)$ \\
\hline Trachea & (10) & (9) & (10) & (10) & (9) & (10) \\
\hline \multicolumn{7}{|l|}{ Special Senses System } \\
\hline None & - & - & - & - & - & - \\
\hline \multicolumn{7}{|l|}{ Urinary System } \\
\hline None & - & - & - & - & - & - \\
\hline
\end{tabular}

${ }^{a}$ Number of animals examined microscopically at the site and the number of animals with lesion. 


\section{Appendix B. Organ Weights and Organ-Weight-to-Body- Weight Ratios}

\section{Tables}

Table B-1. Organ Weights and Organ-Weight-to-Body-Weight Ratios for Rats in the 30-day Inhalation Study of 1020 Long Multiwalled Carbon Nanotubes

Table B-2. Organ Weights and Organ-Weight-to-Body-Weight Ratios for Mice in the 30-day Inhalation Study of 1020 Long Multiwalled Carbon Nanotubes 
Table B-1. Organ Weights and Organ-Weight-to-Body-Weight Ratios for Rats in the 30-day Inhalation Study of 1020 Long Multiwalled Carbon Nanotubes ${ }^{a}$

\begin{tabular}{|c|c|c|c|c|c|c|}
\hline & $\begin{array}{l}\text { Chamber } \\
\text { Control }\end{array}$ & $0.1 \mathrm{mg} / \mathrm{m}^{3}$ & $0.3 \mathrm{mg} / \mathrm{m}^{3}$ & $1 \mathrm{mg} / \mathrm{m}^{3}$ & $3 \mathrm{mg} / \mathrm{m}^{3}$ & $10 \mathrm{mg} / \mathrm{m}^{3}$ \\
\hline n & 10 & 10 & 10 & 10 & 10 & 10 \\
\hline \multicolumn{7}{|l|}{ Male } \\
\hline Necropsy Body Wt. & $288 \pm 6$ & $291 \pm 4$ & $280 \pm 5$ & $282 \pm 7$ & $291 \pm 4$ & $289 \pm 7$ \\
\hline \multicolumn{7}{|l|}{ Heart } \\
\hline Absolute & $1.106 \pm 0.035$ & $1.122 \pm 0.018$ & $1.051 \pm 0.020$ & $1.085 \pm 0.031$ & $1.119 \pm 0.023$ & $1.100 \pm 0.040$ \\
\hline Relative & $3.83 \pm 0.08$ & $3.85 \pm 0.05$ & $3.75 \pm 0.06$ & $3.85 \pm 0.05$ & $3.84 \pm 0.05$ & $3.80 \pm 0.09$ \\
\hline \multicolumn{7}{|l|}{ R. Kidney } \\
\hline Absolute & $1.112 \pm 0.030$ & $1.155 \pm 0.026$ & $1.070 \pm 0.017$ & $1.077 \pm 0.036$ & $1.107 \pm 0.015$ & $1.108 \pm 0.037$ \\
\hline Relative & $3.86 \pm 0.08$ & $3.96 \pm 0.06$ & $3.82 \pm 0.08$ & $3.82 \pm 0.04$ & $3.81 \pm 0.04$ & $3.83 \pm 0.08$ \\
\hline \multicolumn{7}{|l|}{ Liver } \\
\hline Absolute & $12.59 \pm 0.536$ & $12.09 \pm 0.397$ & $11.13 \pm 0.330$ & $11.58 \pm 0.436$ & $12.52 \pm 0.515$ & $12.11 \pm 0.551$ \\
\hline Relative & $43.62 \pm 1.56$ & $41.48 \pm 1.24$ & $39.63 \pm 0.73$ & $41.04 \pm 0.92$ & $42.97 \pm 1.53$ & $41.82 \pm 1.43$ \\
\hline \multicolumn{7}{|l|}{ Lung } \\
\hline Absolute & $2.143 \pm 0.128$ & $2.055 \pm 0.122$ & $1.777 \pm 0.063 *$ & $1.950 \pm 0.076$ & $2.047 \pm 0.078$ & $2.143 \pm 0.078$ \\
\hline Relative & $7.43 \pm 0.42$ & $7.05 \pm 0.39$ & $6.34 \pm 0.22$ & $6.94 \pm 0.28$ & $7.04 \pm 0.26$ & $7.43 \pm 0.24$ \\
\hline \multicolumn{7}{|l|}{ R. Testis } \\
\hline Absolute & $1.842 \pm 0.037$ & $1.819 \pm 0.022$ & $1.745 \pm 0.053$ & $1.845 \pm 0.034$ & $1.743 \pm 0.038$ & $1.732 \pm 0.038$ \\
\hline Relative & $6.41 \pm 0.17$ & $6.25 \pm 0.07$ & $6.23 \pm 0.17$ & $6.56 \pm 0.10$ & $6.00 \pm 0.14$ & $6.02 \pm 0.15$ \\
\hline \multicolumn{7}{|l|}{ Thymus } \\
\hline Absolute & $0.640 \pm 0.020$ & $0.627 \pm 0.043$ & $0.603 \pm 0.034$ & $0.589 \pm 0.022$ & $0.651 \pm 0.019$ & $0.643 \pm 0.033$ \\
\hline Relative & $2.22 \pm 0.07$ & $2.16 \pm 0.17$ & $2.15 \pm 0.11$ & $2.09 \pm 0.05$ & $2.24 \pm 0.08$ & $2.22 \pm 0.09$ \\
\hline \multicolumn{7}{|l|}{ Female } \\
\hline Necropsy Body Wt. & $194 \pm 3$ & $192 \pm 5$ & $195 \pm 3$ & $191 \pm 3$ & $195 \pm 4$ & $194 \pm 4$ \\
\hline \multicolumn{7}{|l|}{ Heart } \\
\hline Absolute & $0.777 \pm 0.019$ & $0.788 \pm 0.029$ & $0.797 \pm 0.018$ & $0.785 \pm 0.020$ & $0.772 \pm 0.025$ & $0.797 \pm 0.026$ \\
\hline Relative & $4.00 \pm 0.07$ & $4.11 \pm 0.09$ & $4.08 \pm 0.06$ & $4.10 \pm 0.07$ & $3.95 \pm 0.08$ & $4.11 \pm 0.08$ \\
\hline \multicolumn{7}{|l|}{ R. Kidney } \\
\hline Absolute & $0.748 \pm 0.013$ & $0.778 \pm 0.019$ & $0.772 \pm 0.017$ & $0.783 \pm 0.016$ & $0.754 \pm 0.017$ & $0.751 \pm 0.023$ \\
\hline Relative & $3.86 \pm 0.06$ & $4.07 \pm 0.08$ & $3.95 \pm 0.06$ & $4.09 \pm 0.06^{*}$ & $3.86 \pm 0.07$ & $3.87 \pm 0.06$ \\
\hline \multicolumn{7}{|l|}{ Liver } \\
\hline Absolute & $7.717 \pm 0.225$ & $7.274 \pm 0.286$ & $7.216 \pm 0.246$ & $7.304 \pm 0.208$ & $7.393 \pm 0.288$ & $7.337 \pm 0.236$ \\
\hline Relative & $39.74 \pm 0.80$ & $37.90 \pm 0.84$ & $36.90 \pm 0.82$ & $38.11 \pm 0.68$ & $37.76 \pm 0.87$ & $37.85 \pm 0.73$ \\
\hline
\end{tabular}




\begin{tabular}{|c|c|c|c|c|c|c|}
\hline & $\begin{array}{c}\text { Chamber } \\
\text { Control }\end{array}$ & $0.1 \mathrm{mg} / \mathrm{m}^{3}$ & $0.3 \mathrm{mg} / \mathrm{m}^{3}$ & $1 \mathrm{mg} / \mathrm{m}^{3}$ & $3 \mathrm{mg} / \mathrm{m}^{3}$ & $10 \mathrm{mg} / \mathrm{m}^{3}$ \\
\hline \multicolumn{7}{|l|}{ Lung } \\
\hline Absolute & $1.417 \pm 0.046$ & $1.319 \pm 0.031$ & $1.408 \pm 0.047$ & $1.482 \pm 0.042$ & $1.498 \pm 0.046$ & $1.765 \pm 0.046^{* *}$ \\
\hline Relative & $7.31 \pm 0.24$ & $6.90 \pm 0.11$ & $7.22 \pm 0.22$ & $7.74 \pm 0.19$ & $7.66 \pm 0.10$ & $9.14 \pm 0.27 * *$ \\
\hline \multicolumn{7}{|l|}{ Thymus } \\
\hline Absolute & $0.444 \pm 0.009$ & $0.464 \pm 0.026$ & $0.440 \pm 0.015$ & $0.442 \pm 0.021$ & $0.493 \pm 0.016$ & $0.455 \pm 0.018$ \\
\hline Relative & $2.29 \pm 0.05$ & $2.41 \pm 0.09$ & $2.26 \pm 0.07$ & $2.31 \pm 0.11$ & $2.52 \pm 0.06$ & $2.36 \pm 0.10$ \\
\hline
\end{tabular}

Table B-2. Organ Weights and Organ-Weight-to-Body-Weight Ratios for Mice in the 30-day Inhalation Study of 1020 Long Multiwalled Carbon Nanotubes ${ }^{a}$

\begin{tabular}{|c|c|c|c|c|c|c|}
\hline & $\begin{array}{c}\text { Chamber } \\
\text { Control }\end{array}$ & $0.1 \mathrm{mg} / \mathrm{m}^{3}$ & $0.3 \mathrm{mg} / \mathrm{m}^{3}$ & $1 \mathrm{mg} / \mathrm{m}^{3}$ & $3 \mathrm{mg} / \mathrm{m}^{3}$ & $10 \mathrm{mg} / \mathrm{m}^{3}$ \\
\hline $\mathbf{n}$ & 10 & 10 & 10 & 10 & 10 & 10 \\
\hline \multicolumn{7}{|l|}{ Male } \\
\hline Necropsy Body Wt. & $27.9 \pm 0.4$ & $27.6 \pm 0.3$ & $27.3 \pm 0.5$ & $27.2 \pm 0.3$ & $27.5 \pm 0.5$ & $27.8 \pm 0.5$ \\
\hline \multicolumn{7}{|l|}{ Heart } \\
\hline Absolute & $0.130 \pm 0.001$ & $0.130 \pm 0.003$ & $0.130 \pm 0.003$ & $0.126 \pm 0.002$ & $0.130 \pm 0.004$ & $0.135 \pm 0.004$ \\
\hline Relative & $4.67 \pm 0.08$ & $4.71 \pm 0.07$ & $4.76 \pm 0.07$ & $4.65 \pm 0.08$ & $4.73 \pm 0.11$ & $4.85 \pm 0.07$ \\
\hline \multicolumn{7}{|l|}{ R. Kidney } \\
\hline Absolute & $0.243 \pm 0.006$ & $0.257 \pm 0.007$ & $0.247 \pm 0.006$ & $0.244 \pm 0.005$ & $0.253 \pm 0.006$ & $0.254 \pm 0.007$ \\
\hline Relative & $8.73 \pm 0.18$ & $9.31 \pm 0.18$ & $9.05 \pm 0.19$ & $9.00 \pm 0.18$ & $9.21 \pm 0.12$ & $9.12 \pm 0.16$ \\
\hline \multicolumn{7}{|l|}{ Liver } \\
\hline Absolute & $1.292 \pm 0.046$ & $1.310 \pm 0.041$ & $1.309 \pm 0.029$ & $1.295 \pm 0.022$ & $1.347 \pm 0.038$ & $1.290 \pm 0.041$ \\
\hline Relative & $46.32 \pm 1.33$ & $47.41 \pm 1.00$ & $47.97 \pm 0.95$ & $47.73 \pm 0.78$ & $49.05 \pm 0.92$ & $46.31 \pm 1.02$ \\
\hline \multicolumn{7}{|l|}{ Lung } \\
\hline Absolute & $0.184 \pm 0.006$ & $0.188 \pm 0.006$ & $0.184 \pm 0.004$ & $0.192 \pm 0.004$ & $0.210 \pm 0.002 * *$ & $0.258 \pm 0.004^{*} *$ \\
\hline Relative & $6.61 \pm 0.21$ & $6.82 \pm 0.19$ & $6.73 \pm 0.08$ & $7.08 \pm 0.16$ & $7.67 \pm 0.13 * *$ & $9.29 \pm 0.19 * *$ \\
\hline \multicolumn{7}{|l|}{ R. Testis } \\
\hline Absolute & $0.101 \pm 0.003$ & $0.104 \pm 0.002$ & $0.100 \pm 0.003$ & $0.102 \pm 0.002$ & $0.098 \pm 0.003$ & $0.099 \pm 0.004$ \\
\hline Relative & $3.63 \pm 0.08$ & $3.79 \pm 0.10$ & $3.65 \pm 0.09$ & $3.75 \pm 0.05$ & $3.58 \pm 0.10$ & $3.55 \pm 0.16$ \\
\hline \multicolumn{7}{|l|}{ Thymus } \\
\hline Absolute & $0.061 \pm 0.003$ & $0.061 \pm 0.003$ & $0.065 \pm 0.002$ & $0.065 \pm 0.002$ & $0.062 \pm 0.003$ & $0.066 \pm 0.003$ \\
\hline Relative & $2.17 \pm 0.10$ & $2.22 \pm 0.08$ & $2.37 \pm 0.10$ & $2.41 \pm 0.08$ & $2.27 \pm 0.09$ & $2.36 \pm 0.10$ \\
\hline
\end{tabular}


L-MWNT-1020, NTP TOX 94

\begin{tabular}{|c|c|c|c|c|c|c|}
\hline & $\begin{array}{l}\text { Chamber } \\
\text { Control }\end{array}$ & $0.1 \mathrm{mg} / \mathrm{m}^{3}$ & $0.3 \mathrm{mg} / \mathrm{m}^{3}$ & $1 \mathrm{mg} / \mathrm{m}^{3}$ & $3 \mathrm{mg} / \mathrm{m}^{3}$ & $10 \mathrm{mg} / \mathrm{m}^{3}$ \\
\hline \multicolumn{7}{|l|}{ Female } \\
\hline Necropsy Body Wt. & $24.4 \pm 0.5$ & $24.1 \pm 0.4$ & $24.5 \pm 0.4$ & $24.7 \pm 0.3$ & $23.8 \pm 0.3$ & $24.8 \pm 0.3$ \\
\hline \multicolumn{7}{|l|}{ Heart } \\
\hline Absolute & $0.122 \pm 0.002$ & $0.118 \pm 0.002$ & $0.123 \pm 0.002$ & $0.123 \pm 0.002$ & $0.120 \pm 0.002$ & $0.122 \pm 0.001$ \\
\hline Relative & $5.00 \pm 0.12$ & $4.91 \pm 0.09$ & $5.03 \pm 0.08$ & $4.98 \pm 0.10$ & $5.05 \pm 0.10$ & $4.93 \pm 0.09$ \\
\hline \multicolumn{7}{|l|}{ R. Kidney } \\
\hline Absolute & $0.179 \pm 0.006$ & $0.182 \pm 0.004$ & $0.185 \pm 0.005$ & $0.189 \pm 0.003$ & $0.185 \pm 0.004$ & $0.190 \pm 0.005$ \\
\hline Relative & $7.31 \pm 0.17$ & $7.56 \pm 0.09$ & $7.56 \pm 0.13$ & $7.65 \pm 0.13$ & $7.77 \pm 0.13$ & $7.66 \pm 0.13$ \\
\hline \multicolumn{7}{|l|}{ Liver } \\
\hline Absolute & $1.190 \pm 0.035$ & $1.162 \pm 0.041$ & $1.194 \pm 0.040$ & $1.191 \pm 0.025$ & $1.167 \pm 0.025$ & $1.187 \pm 0.026$ \\
\hline Relative & $48.68 \pm 0.96$ & $48.22 \pm 1.28$ & $48.74 \pm 1.02$ & $48.20 \pm 0.91$ & $49.03 \pm 0.87$ & $47.87 \pm 0.84$ \\
\hline \multicolumn{7}{|l|}{ Lung } \\
\hline Absolute & $0.180 \pm 0.005$ & $0.180 \pm 0.004$ & $0.188 \pm 0.006$ & $0.194 \pm 0.007$ & $0.199 \pm 0.003^{*}$ & $0.255 \pm 0.005^{* *}$ \\
\hline Relative & $7.37 \pm 0.12$ & $7.48 \pm 0.12$ & $7.68 \pm 0.19$ & $7.86 \pm 0.30$ & $8.36 \pm 0.10 * *$ & $10.29 \pm 0.17 * *$ \\
\hline \multicolumn{7}{|l|}{ Thymus } \\
\hline Absolute & $0.074 \pm 0.003$ & $0.075 \pm 0.002$ & $0.075 \pm 0.002$ & $0.073 \pm 0.002$ & $0.071 \pm 0.002$ & $0.072 \pm 0.002$ \\
\hline Relative & $3.01 \pm 0.08$ & $3.14 \pm 0.07$ & $3.06 \pm 0.06$ & $2.96 \pm 0.09$ & $2.98 \pm 0.06$ & $2.91 \pm 0.09$ \\
\hline
\end{tabular}

*Significantly different $(\mathrm{p} \leq 0.05)$ from the chamber control group by Williams' test.

$* * \mathrm{p} \leq 0.01$.

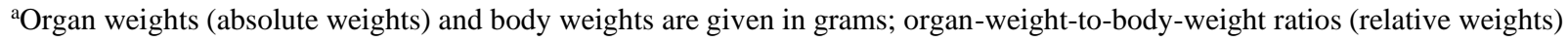
are given as $\mathrm{mg}$ organ weight/g body weight (mean \pm standard error). 


\section{Appendix C. Lung Burden Results}

\section{Tables}

Table C-1. Postexposure Survival and Body Weights of Lung Burden Rats in the 30-day Inhalation Study of 1020 Long Multiwalled Carbon Nanotubes.

Table C-2. Postexposure Survival and Body Weights of Lung Burden Mice in the 30-day Inhalation Study of 1020 Long Multiwalled Carbon Nanotubes.

\section{Figures}

Figure C-1. Lung 1020 Long Multiwalled Carbon Nanotube Burdens in $0.1 \mathrm{mg} / \mathrm{m}^{3}$ Rats in the 30-day Inhalation Study of 1020 Long Multiwalled Carbon Nanotubes .......C-6

Figure C-2. Lung 1020 Long Multiwalled Carbon Nanotube Burdens in $0.3 \mathrm{mg} / \mathrm{m}^{3}$ Rats in the 30-day Inhalation Study of 1020 Long Multiwalled Carbon Nanotubes .......C-7

Figure C-3. Lung 1020 Long Multiwalled Carbon Nanotube Burdens in $1 \mathrm{mg} / \mathrm{m}^{3}$ Rats in the 30-day Inhalation Study of 1020 Long Multiwalled Carbon Nanotubes ............ -8

Figure C-4. Lung 1020 Long Multiwalled Carbon Nanotube Burdens in $3 \mathrm{mg} / \mathrm{m}^{3}$ Rats in the 30-day Inhalation Study of 1020 Long Multiwalled Carbon Nanotubes

Figure C-5. Lung 1020 Long Multiwalled Carbon Nanotube Burdens in $10 \mathrm{mg} / \mathrm{m}^{3}$ Rats in the 30-day Inhalation Study of 1020 Long Multiwalled Carbon Nanotubes .....C-10

Figure C-6. Lung 1020 Long Multiwalled Carbon Nanotube Burdens in $0.1 \mathrm{mg} / \mathrm{m}^{3}$ Mice in the 30-day Inhalation Study of 1020 Long Multiwalled Carbon Nanotubes .....C-11

Figure C-7. Lung 1020 Long Multiwalled Carbon Nanotube Burdens in $0.3 \mathrm{mg} / \mathrm{m}^{3}$ Mice in the 30-day Inhalation Study of 1020 Long Multiwalled Carbon Nanotubes .....C-12

Figure C-8. Lung 1020 Long Multiwalled Carbon Nanotube Burdens in $1 \mathrm{mg} / \mathrm{m}^{3}$ Mice in the 30-day Inhalation Study of 1020 Long Multiwalled Carbon Nanotubes

Figure C-9. Lung 1020 Long Multiwalled Carbon Nanotube Burdens in $3 \mathrm{mg} / \mathrm{m}^{3}$ Mice in the 30-day Inhalation Study of 1020 Long Multiwalled Carbon Nanotubes C-14

Figure C-10. Lung 1020 Long Multiwalled Carbon Nanotube Burdens in $10 \mathrm{mg} / \mathrm{m}^{3}$ Mice in the 30-day Inhalation Study of 1020 Long Multiwalled Carbon Nanotubes 
Table C-1. Postexposure Survival and Body Weights of Lung Burden Rats in the 30-day Inhalation Study of 1020 Long Multiwalled Carbon Nanotubes ${ }^{a}$

\begin{tabular}{lccccc}
\hline $\begin{array}{c}\text { Concentration } \\
\left(\mathrm{mg} / \mathrm{m}^{3}\right)\end{array}$ & Survival $^{\mathrm{b}}$ & $\begin{array}{c}\text { Initial Body } \\
\text { Weight }(\mathrm{g})\end{array}$ & $\begin{array}{c}\text { Final Body } \\
\text { Weight }(\mathrm{g})\end{array}$ & $\begin{array}{c}\text { Change in Body } \\
\text { Weight }(\mathrm{g})\end{array}$ & $\begin{array}{c}\text { Final Weight } \\
\text { Relative to } \\
\text { Controls }(\%)\end{array}$ \\
\hline Male & & &
\end{tabular}

Day 0

$\begin{array}{cccccc}0 & 10 / 10 & 121 \pm 3 & 268 \pm 6 & 147 \pm 5 & \\ 0.1 & 10 / 10 & 124 \pm 3 & 275 \pm 4 & 151 \pm 4 & 103 \\ 0.3 & 10 / 10 & 124 \pm 3 & 259 \pm 5 & 136 \pm 4 & 97 \\ 1 & 10 / 10 & 122 \pm 2 & 262 \pm 9 & 141 \pm 8 & 98 \\ 3 & 10 / 10 & 122 \pm 4 & 276 \pm 8 & 154 \pm 6 & 103 \\ 10 & 10 / 10 & 114 \pm 2 & 261 \pm 6 & 147 \pm 5 & 97\end{array}$

Day 14

$\begin{array}{cc}0 & 5 / 5 \\ 0.1 & 5 / 5 \\ 0.3 & 5 / 5 \\ 1 & 5 / 5 \\ 3 & 5 / 5 \\ 10 & 5 / 5\end{array}$

Day 42

$\begin{array}{cc}0 & 5 / 5 \\ 0.1 & 5 / 5 \\ 0.3 & 5 / 5 \\ 1 & 5 / 5 \\ 3 & 5 / 5 \\ 10 & 5 / 5\end{array}$

Day 126

\begin{tabular}{cccccc}
0 & $5 / 5$ & $124 \pm 4$ & $437 \pm 36$ & $313 \pm 33$ & \\
0.1 & $5 / 5$ & $123 \pm 3$ & $429 \pm 7$ & $307 \pm 6$ & 98 \\
0.3 & $5 / 5$ & $121 \pm 3$ & $431 \pm 5$ & $310 \pm 5$ & 99 \\
1 & $5 / 5$ & $121 \pm 3$ & $445 \pm 10$ & $325 \pm 11$ & 102 \\
3 & $5 / 5$ & $115 \pm 4$ & $425 \pm 16$ & $310 \pm 14$ & 97 \\
10 & $5 / 5$ & $121 \pm 4$ & $451 \pm 12$ & $330 \pm 14$ & 103 \\
\hline
\end{tabular}




\begin{tabular}{cccccc}
\hline $\begin{array}{c}\text { Concentration } \\
\left(\mathbf{m g} / \mathbf{m}^{3}\right)\end{array}$ & Survival $^{\text {b }}$ & $\begin{array}{c}\text { Initial Body } \\
\text { Weight }(\mathrm{g})\end{array}$ & $\begin{array}{c}\text { Final Body } \\
\text { Weight }(\mathrm{g})\end{array}$ & $\begin{array}{c}\text { Change in Body } \\
\text { Weight }(\mathrm{g})\end{array}$ & $\begin{array}{c}\text { Final Weight } \\
\text { Relative to } \\
\text { Controls }(\%)\end{array}$ \\
\hline
\end{tabular}

\section{Female}

Day 0

$\begin{array}{cccccc}0 & 10 / 10 & 109 \pm 2 & 182 \pm 3 & 72 \pm 3 & \\ 0.1 & 10 / 10 & 108 \pm 2 & 182 \pm 3 & 74 \pm 2 & 100 \\ 0.3 & 10 / 10 & 103 \pm 1 & 180 \pm 3 & 77 \pm 3 & 99 \\ 1 & 10 / 10 & 106 \pm 2 & 177 \pm 3 & 71 \pm 2 & 97 \\ 3 & 109 \pm 2 & 186 \pm 2 & 77 \pm 2 & 102 \\ 10 & 10 / 10 & 108 \pm 2 & 186 \pm 4 & 77 \pm 3 & 102\end{array}$

Day 14

$\begin{array}{cccccc}0 & 5 / 5 & 107 \pm 3 & 207 \pm 4 & 100 \pm 4 & \\ 0.1 & 5 / 5 & 108 \pm 3 & 204 \pm 10 & 95 \pm 8 & 98 \\ 0.3 & 5 / 5 & 103 \pm 3 & 193 \pm 3 & 90 \pm 2 & 94 \\ 1 & 5 / 5 & 105 \pm 2 & 205 \pm 5 & 101 \pm 5 & 99 \\ 3 & 5 / 5 & 105 \pm 3 & 202 \pm 5 & 97 \pm 3 & 98 \\ 10 & 5 / 5 & 105 \pm 2 & 207 \pm 6 & 101 \pm 5 & 100\end{array}$

Day 42

$\begin{array}{cccccc}0 & 5 / 5 & 108 \pm 4 & 223 \pm 5 & 115 \pm 4 \\ 0.1 & 5 / 5 & 107 \pm 3 & 229 \pm 7 & 122 \pm 7 & 103 \\ 0.3 & 5 / 5 & 104 \pm 5 & 225 \pm 5 & 122 \pm 5 & 101 \\ 1 & 5 / 5 & 108 \pm 2 & 235 \pm 4 & 127 \pm 3 & 105 \\ 3 & 5 / 5 & 102 \pm 2 & 229 \pm 5 & 127 \pm 6 & 103 \\ 10 & 5 / 5 & 104 \pm 1 & 215 \pm 3 & 111 \pm 3 & 97\end{array}$

Day 126

$\begin{array}{cccccc}0 & 5 / 5 & 108 \pm 3 & 256 \pm 3 & 147 \pm 3 & \\ 0.1 & 5 / 5 & 108 \pm 3 & 264 \pm 5 & 156 \pm 7 & 103 \\ 0.3 & 5 / 5 & 112 \pm 2 & 263 \pm 8 & 152 \pm 7 & 103 \\ 1 & 5 / 5 & 105 \pm 5 & 260 \pm 9 & 155 \pm 7 & 102 \\ 3 & 5 / 5 & 105 \pm 3 & 268 \pm 7 & 163 \pm 4 & 105 \\ 10 & 5 / 5 & 108 \pm 2 & 264 \pm 4 & 155 \pm 4 & 103\end{array}$

${ }^{\text {a}}$ Weights and weight changes are given as mean \pm standard error. Differences from the chamber control group are not significant by Dunnett's test.

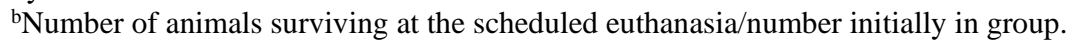


Table C-2. Postexposure Survival and Body Weights of Lung Burden Mice in the 30-day Inhalation Study of 1020 Long Multiwalled Carbon Nanotubes ${ }^{a}$

\begin{tabular}{lccccc}
\hline $\begin{array}{c}\text { Concentration } \\
\left(\mathrm{mg} / \mathrm{m}^{3}\right)\end{array}$ & Survival $^{\mathrm{b}}$ & $\begin{array}{c}\text { Initial Body } \\
\text { Weight }(\mathrm{g})\end{array}$ & $\begin{array}{c}\text { Final Body } \\
\text { Weight }(\mathrm{g})\end{array}$ & $\begin{array}{c}\text { Change in Body } \\
\text { Weight }(\mathrm{g})\end{array}$ & $\begin{array}{c}\text { Final Weight } \\
\text { Relative to } \\
\text { Controls }(\%)\end{array}$ \\
\hline Male & & &
\end{tabular}

Day 0

$\begin{array}{cccccc}0 & 10 / 10 & 22.5 \pm 0.5 & 25.8 \pm 0.5 & 3.3 \pm 0.2 & \\ 0.1 & 10 / 10 & 22.2 \pm 0.3 & 25.3 \pm 0.3 & 3.1 \pm 0.2 & 98 \\ 0.3 & 10 / 10 & 22.0 \pm 0.2 & 24.9 \pm 0.3 & 2.9 \pm 0.3 & 97 \\ 1 & 10 / 10 & 21.6 \pm 0.2 & 24.9 \pm 0.3 & 3.3 \pm 0.2 & 97 \\ 3 & 10 / 10 & 22.3 \pm 0.2 & 25.4 \pm 0.4 & 3.1 \pm 0.3 & 98 \\ 10 & 10 / 10 & 22.8 \pm 0.4 & 26.0 \pm 0.5 & 3.2 \pm 0.3 & 101\end{array}$

Day 14

0.3

1

3

10

Day 42

0

0.1

0.3

1

3

10

Day 126

$\begin{array}{cc}0 & 5 / 5 \\ 0.1 & 5 / 5 \\ 0.3 & 5 / 5 \\ 1 & 5 / 5 \\ 3 & 5 / 5 \\ 10 & 5 / 5\end{array}$

$5 / 5$

$5 / 5$

$5 / 5$

$5 / 5$

$5 / 5$

$5 / 5$

$5 / 5$

$5 / 5$

$5 / 5$

$5 / 5$

$5 / 5$

$5 / 5$

$5 / 5$

$5 / 5$

$5 / 5$

$5 / 5$

$5 / 5$

$5 / 5$
$22.2 \pm 0.2$

$22.6 \pm 0.6$

$22.3 \pm 0.6$

$22.8 \pm 0.4$

$21.5 \pm 0.4$

$21.3 \pm 0.5$

$22.0 \pm 0.2$

$21.2 \pm 0.4$

$22.1 \pm 0.3$

$21.9 \pm 0.6$

$22.5 \pm 0.6$

$22.5 \pm 0.4$

$22.5 \pm 0.6$

$21.8 \pm 0.6$

$22.9 \pm 0.3$

$23.2 \pm 0.3$

$22.2 \pm 0.6$

$22.0 \pm 0.3$
$27.4 \pm 0.4$

$27.4 \pm 0.7$

$27.4 \pm 0.4$

$27.3 \pm 0.5$

$27.2 \pm 0.5$

$25.6 \pm 0.7$

$30.3 \pm 0.3$

$30.0 \pm 0.7$

$29.7 \pm 1.0$

$29.9 \pm 0.8$

$32.2 \pm 1.5$

$31.3 \pm 0.6$

$41.0 \pm 1.5$

$40.2 \pm 2.6$

$39.0 \pm 0.8$

$41.0 \pm 0.8$

$39.8 \pm 1.7$

$42.0 \pm 0.8$

$5.2 \pm 0.2$

$4.8 \pm 0.4$

100

$5.1 \pm 0.5$

100

$4.5 \pm 0.5$

100

$5.6 \pm 0.3$

99

$4.3 \pm 0.5$

94

9
9
8
01




\begin{tabular}{cccccc}
\hline $\begin{array}{c}\text { Concentration } \\
\left(\mathrm{mg}^{\prime} \mathbf{m}^{3}\right)\end{array}$ & Survival $^{\mathrm{b}}$ & $\begin{array}{c}\text { Initial Body } \\
\text { Weight }(\mathrm{g})\end{array}$ & $\begin{array}{c}\text { Final Body } \\
\text { Weight }(\mathrm{g})\end{array}$ & $\begin{array}{c}\text { Change in Body } \\
\text { Weight }(\mathrm{g})\end{array}$ & $\begin{array}{c}\text { Final Weight } \\
\text { Relative to } \\
\text { Controls }(\%)\end{array}$ \\
\hline
\end{tabular}

\section{Female}

Day 0

$\begin{array}{cccccc}0 & 10 / 10 & 18.9 \pm 0.2 & 21.6 \pm 0.2 & 2.7 \pm 0.1 & \\ 0.1 & 10 / 10 & 19.7 \pm 0.4 & 22.3 \pm 0.3 & 2.7 \pm 0.3 & 103 \\ 0.3 & 10 / 10 & 19.0 \pm 0.3 & 21.6 \pm 0.4 & 2.6 \pm 0.3 & 100 \\ 1 & 10 / 10 & 19.1 \pm 0.2 & 22.0 \pm 0.3 & 2.9 \pm 0.2 & 102 \\ 3 & 10 / 10 & 19.1 \pm 0.3 & 21.4 \pm 0.3 & 2.3 \pm 0.2 & 99 \\ 10 & 10 / 10 & 18.5 \pm 0.3 & 21.0 \pm 0.2 & 2.4 \pm 0.2 & 97\end{array}$

Day 14

$\begin{array}{cccccc}0 & 5 / 5 & 18.9 \pm 0.6 & 23.9 \pm 0.5 & 5.0 \pm 0.5 & \\ 0.1 & 5 / 5 & 18.3 \pm 0.4 & 22.8 \pm 0.6 & 4.5 \pm 0.3 & 96 \\ 0.3 & 5 / 5 & 19.1 \pm 0.5 & 23.0 \pm 0.7 & 3.9 \pm 0.2 & 96 \\ 1 & 5 / 5 & 19.4 \pm 0.3 & 24.3 \pm 0.2 & 4.9 \pm 0.3 & 102 \\ 3 & 5 / 5 & 18.1 \pm 0.7 & 22.6 \pm 0.2 & 4.5 \pm 0.5 & 95 \\ 10 & 5 / 5 & 19.5 \pm 0.4 & 24.0 \pm 0.8 & 4.5 \pm 0.4 & 100\end{array}$

Day 42

$\begin{array}{cccccc}0 & 5 / 5 & 18.9 \pm 0.5 & 25.9 \pm 0.7 & 7.0 \pm 0.5 & \\ 0.1 & 5 / 5 & 18.8 \pm 0.5 & 24.1 \pm 0.7 & 5.3 \pm 0.5 & 93 \\ 0.3 & 5 / 5 & 19.3 \pm 0.7 & 24.8 \pm 0.3 & 5.5 \pm 0.5 & 96 \\ 1 & 5 / 5 & 19.0 \pm 0.3 & 25.7 \pm 0.6 & 6.7 \pm 0.5 & 99 \\ 3 & 5 / 5 & 19.0 \pm 0.2 & 24.8 \pm 0.5 & 5.9 \pm 0.5 & 96 \\ 10 & 5 / 5 & 18.6 \pm 0.4 & 25.8 \pm 0.7 & 7.2 \pm 0.6 & 100\end{array}$

Day 126

\begin{tabular}{cccccc}
0 & $5 / 5$ & $20.1 \pm 0.4$ & $37.3 \pm 0.9$ & $17.2 \pm 0.9$ & \\
0.1 & $5 / 5$ & $18.8 \pm 0.2$ & $37.5 \pm 1.3$ & $18.7 \pm 1.2$ & 101 \\
0.3 & $5 / 5$ & $19.3 \pm 0.6$ & $38.1 \pm 1.3$ & $18.8 \pm 0.9$ & 102 \\
1 & $5 / 5$ & $18.0 \pm 0.2^{* *}$ & $33.6 \pm 2.3$ & $15.6 \pm 2.3$ & 90 \\
3 & $5 / 5$ & $19.3 \pm 0.3$ & $37.4 \pm 2.1$ & $18.1 \pm 1.9$ & 100 \\
10 & $5 / 5$ & $18.8 \pm 0.5$ & $30.8 \pm 1.0^{*}$ & $12.0 \pm 1.3$ & 83 \\
\hline
\end{tabular}

*Significantly different $(\mathrm{p} \leq 0.05)$ from the chamber control group by Dunnett's test. $* * \mathrm{p} \leq 0.01$.

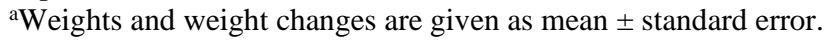

${ }^{b}$ Number of animals surviving at the scheduled euthanasia/number initially in group. 

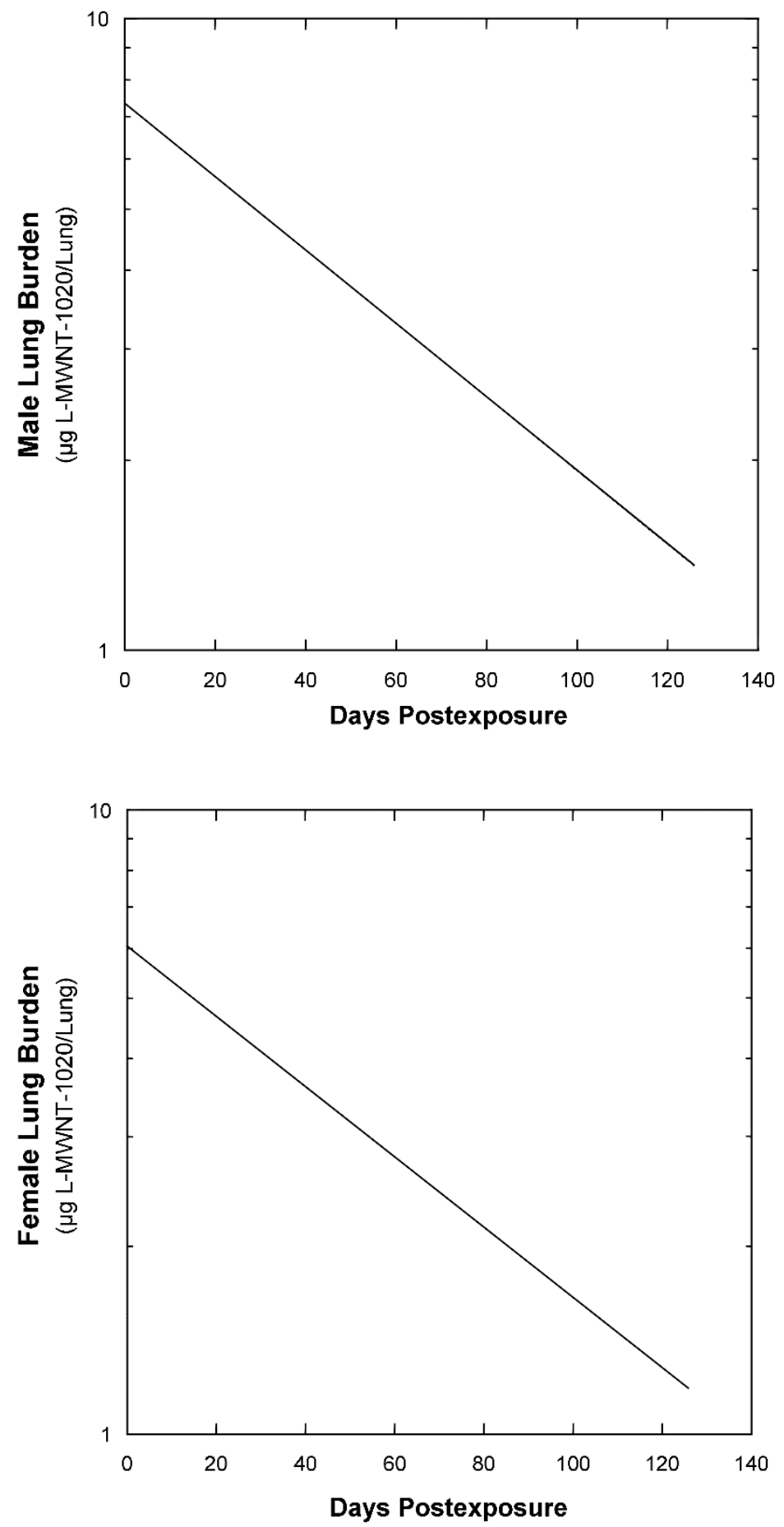

Figure C-1. Lung 1020 Long Multiwalled Carbon Nanotube Burdens in $0.1 \mathrm{mg} / \mathrm{m}^{3}$ Rats in the 30-day Inhalation Study of 1020 Long Multiwalled Carbon Nanotubes 

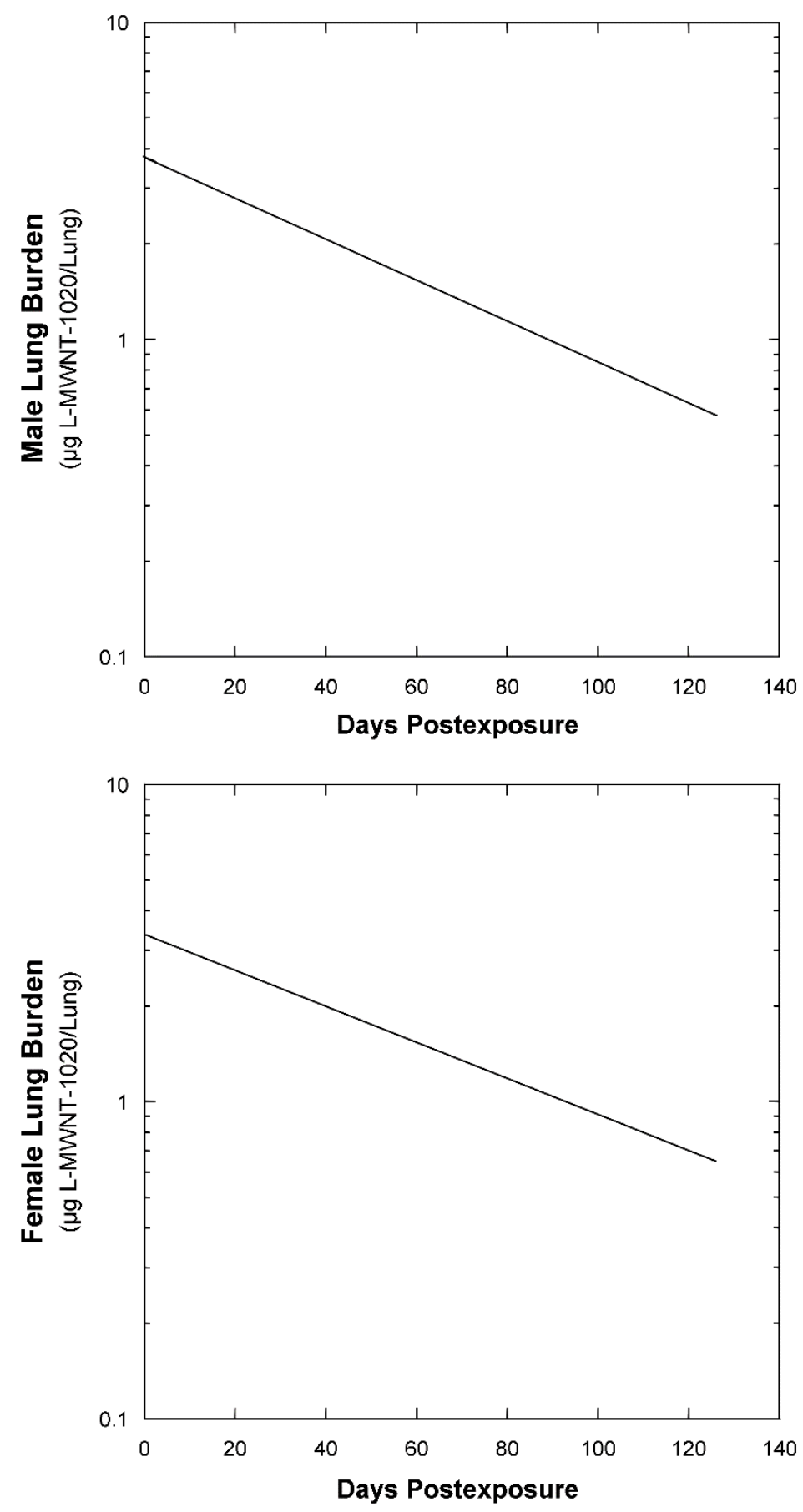

Figure C-2. Lung 1020 Long Multiwalled Carbon Nanotube Burdens in $0.3 \mathrm{mg} / \mathrm{m}^{3}$ Rats in the 30-day Inhalation Study of 1020 Long Multiwalled Carbon Nanotubes 

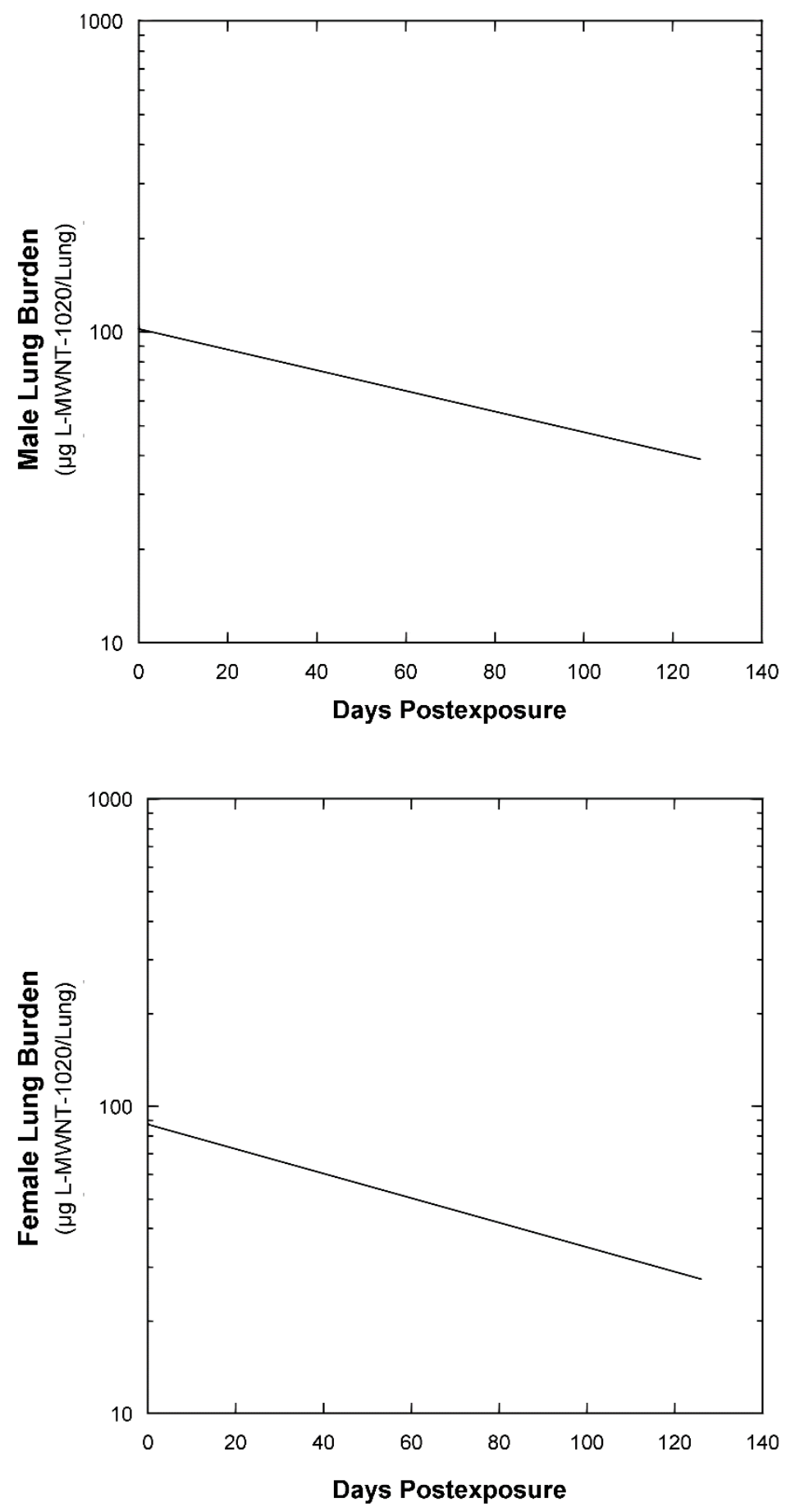

Figure C-3. Lung 1020 Long Multiwalled Carbon Nanotube Burdens in $1 \mathrm{mg} / \mathrm{m}^{3}$ Rats in the 30-day Inhalation Study of 1020 Long Multiwalled Carbon Nanotubes 

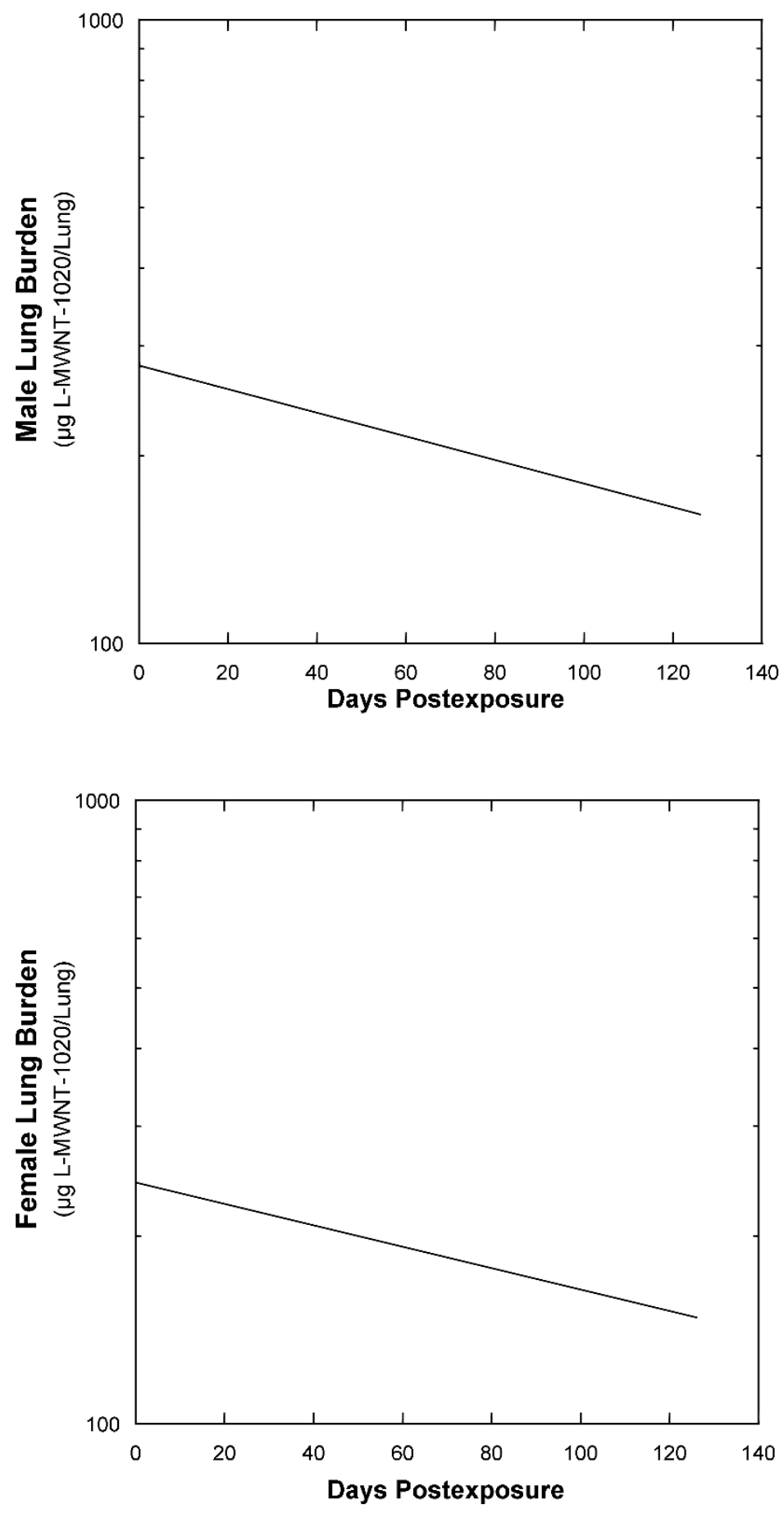

Figure C-4. Lung 1020 Long Multiwalled Carbon Nanotube Burdens in $3 \mathrm{mg} / \mathrm{m}^{3}$ Rats in the 30-day Inhalation Study of 1020 Long Multiwalled Carbon Nanotubes 

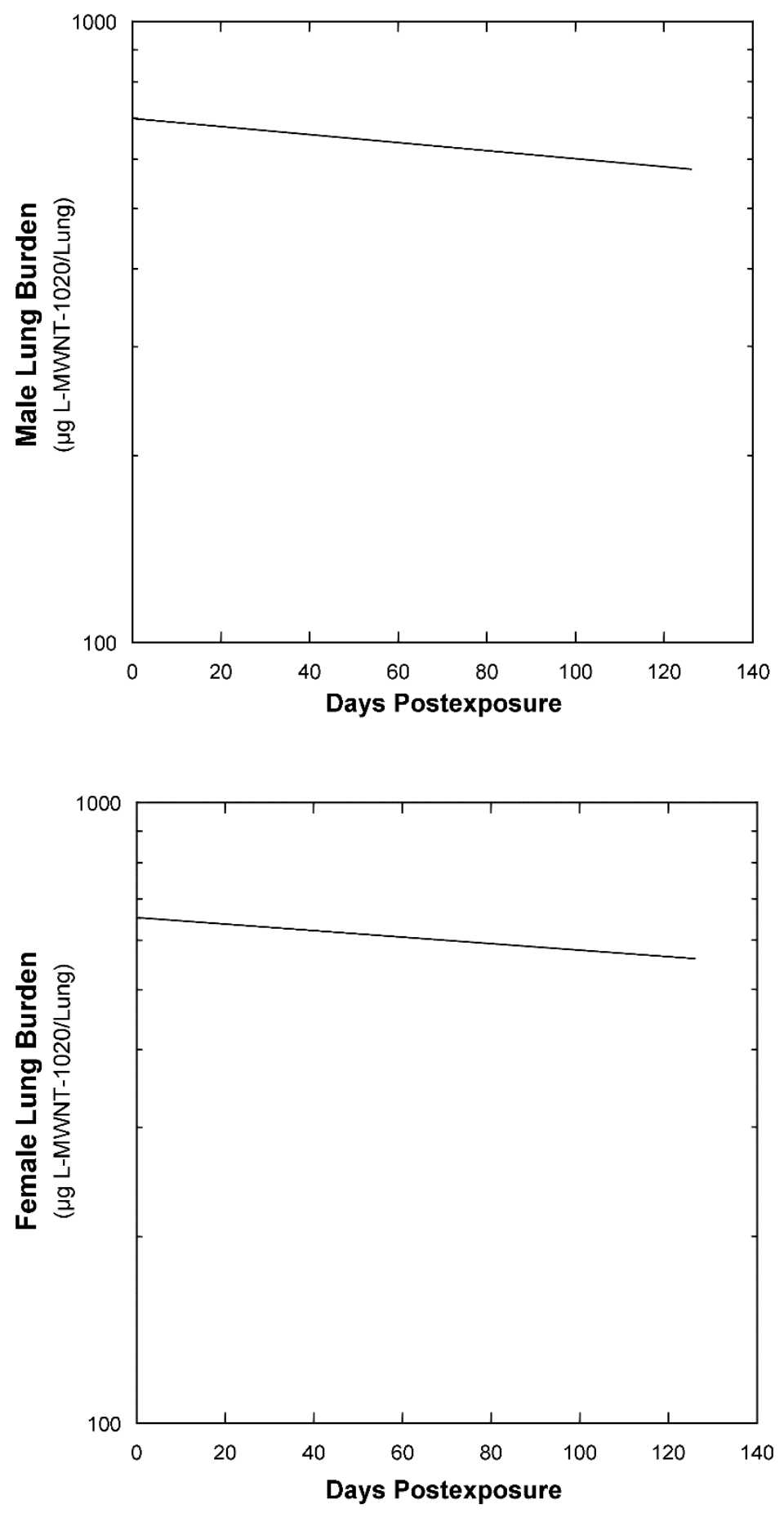

Figure C-5. Lung 1020 Long Multiwalled Carbon Nanotube Burdens in $10 \mathrm{mg} / \mathrm{m}^{3}$ Rats in the 30-day Inhalation Study of 1020 Long Multiwalled Carbon Nanotubes 

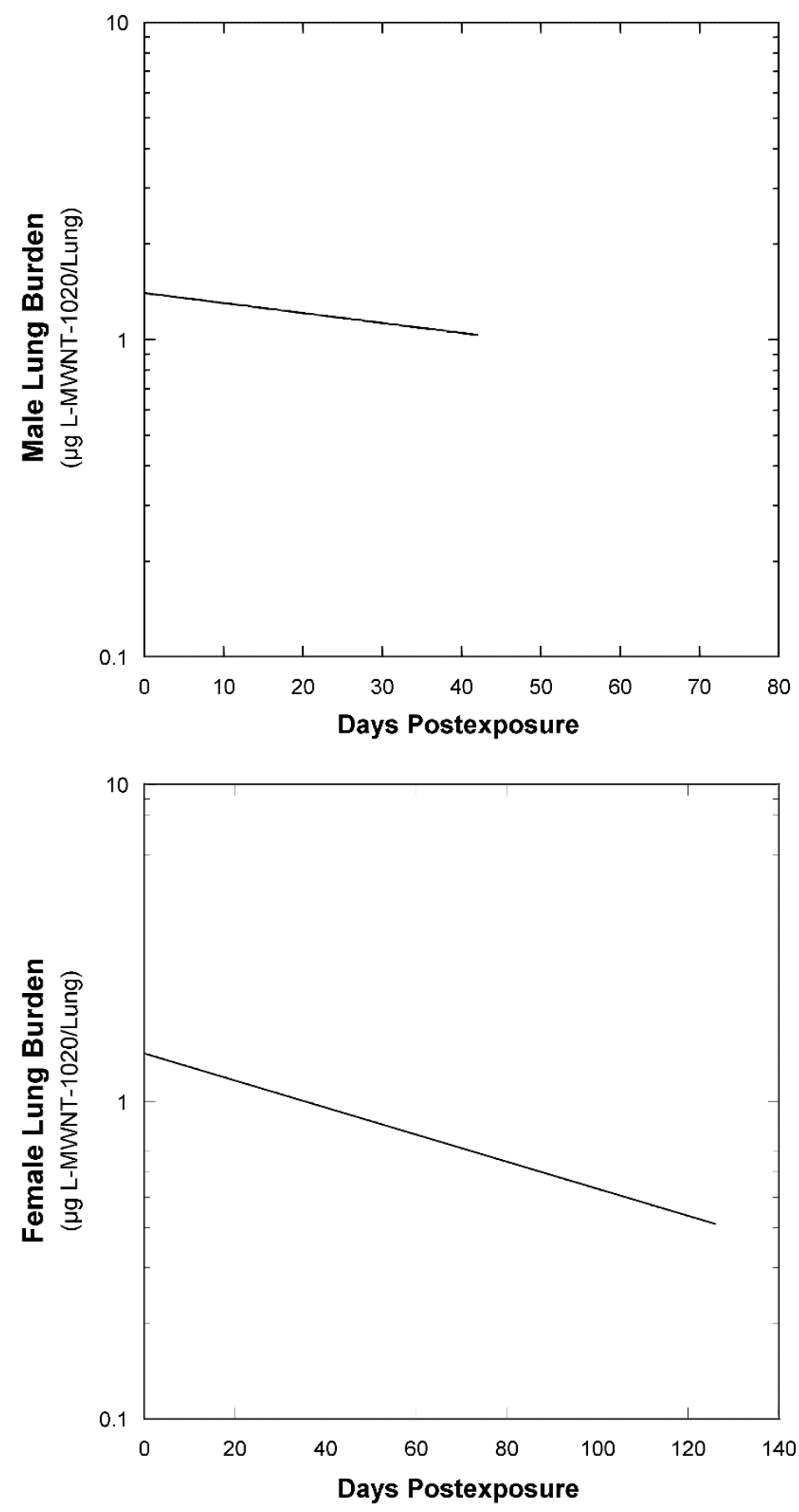

Figure C-6. Lung 1020 Long Multiwalled Carbon Nanotube Burdens in $0.1 \mathrm{mg} / \mathrm{m}^{3}$ Mice in the 30day Inhalation Study of 1020 Long Multiwalled Carbon Nanotubes 

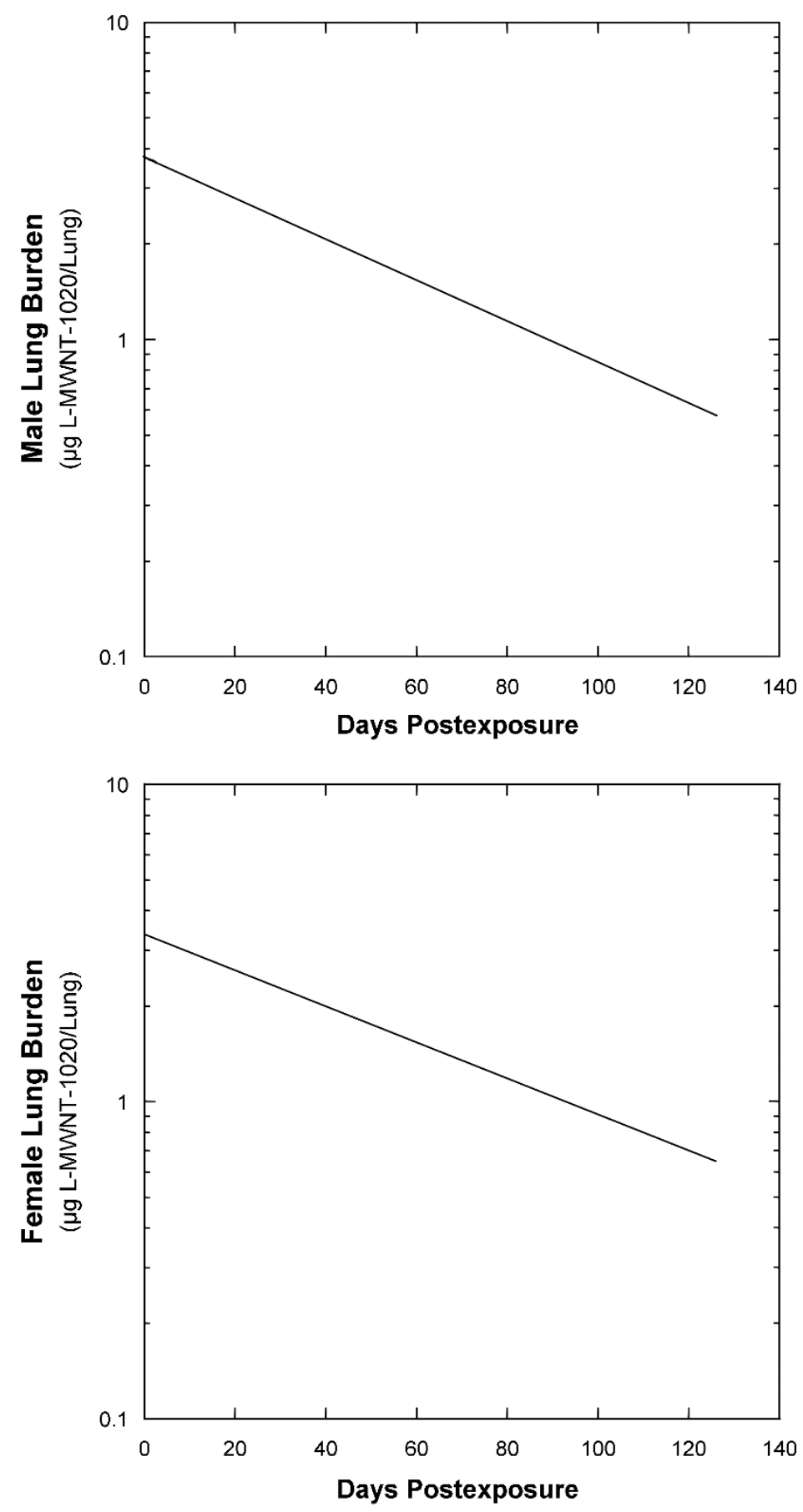

Figure C-7. Lung 1020 Long Multiwalled Carbon Nanotube Burdens in $0.3 \mathrm{mg} / \mathrm{m}^{3}$ Mice in the 30-day Inhalation Study of 1020 Long Multiwalled Carbon Nanotubes 

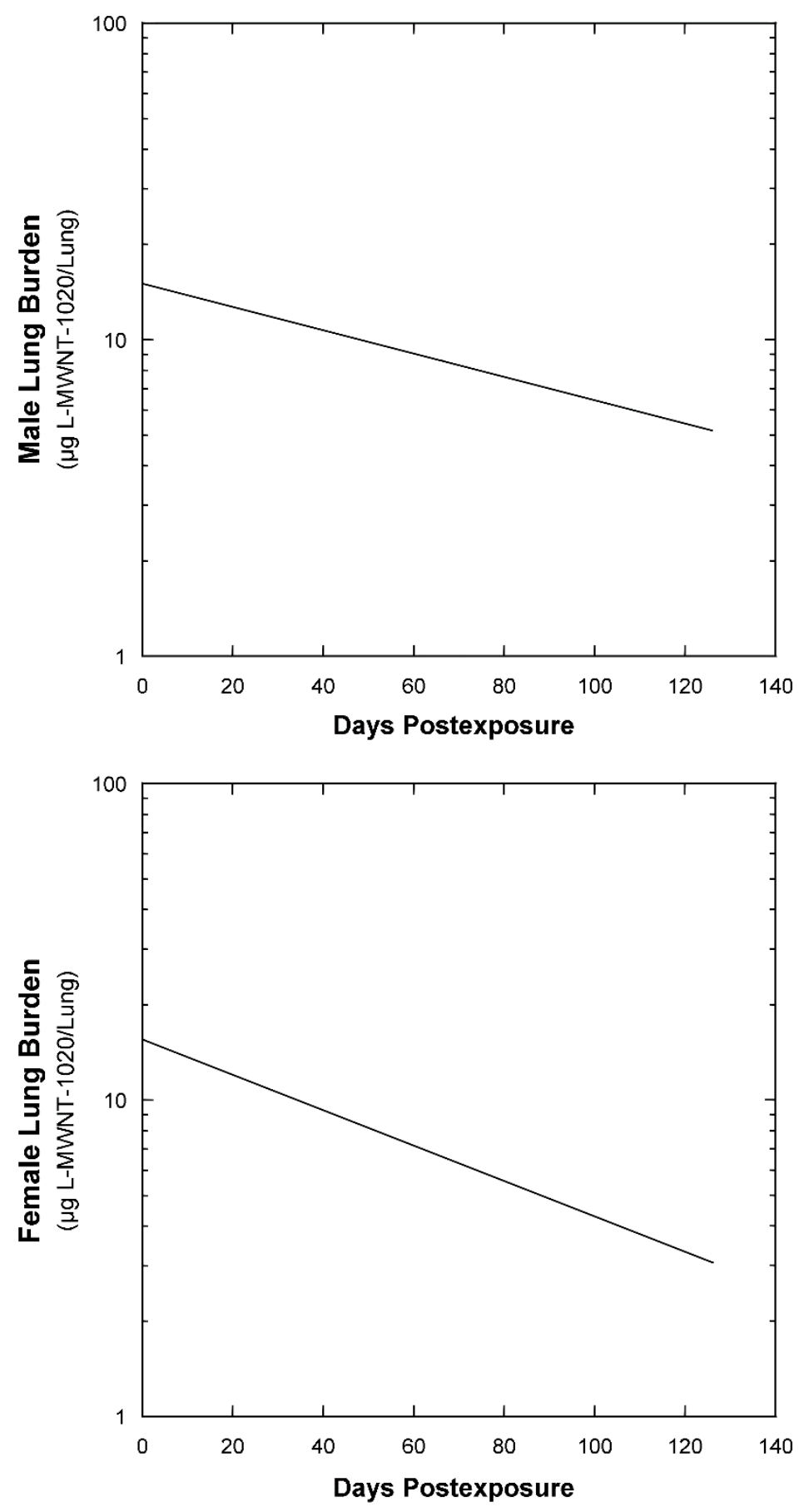

Figure C-8. Lung 1020 Long Multiwalled Carbon Nanotube Burdens in 1 mg/m $\mathrm{m}^{3}$ Mice in the 30-day Inhalation Study of 1020 Long Multiwalled Carbon Nanotubes 

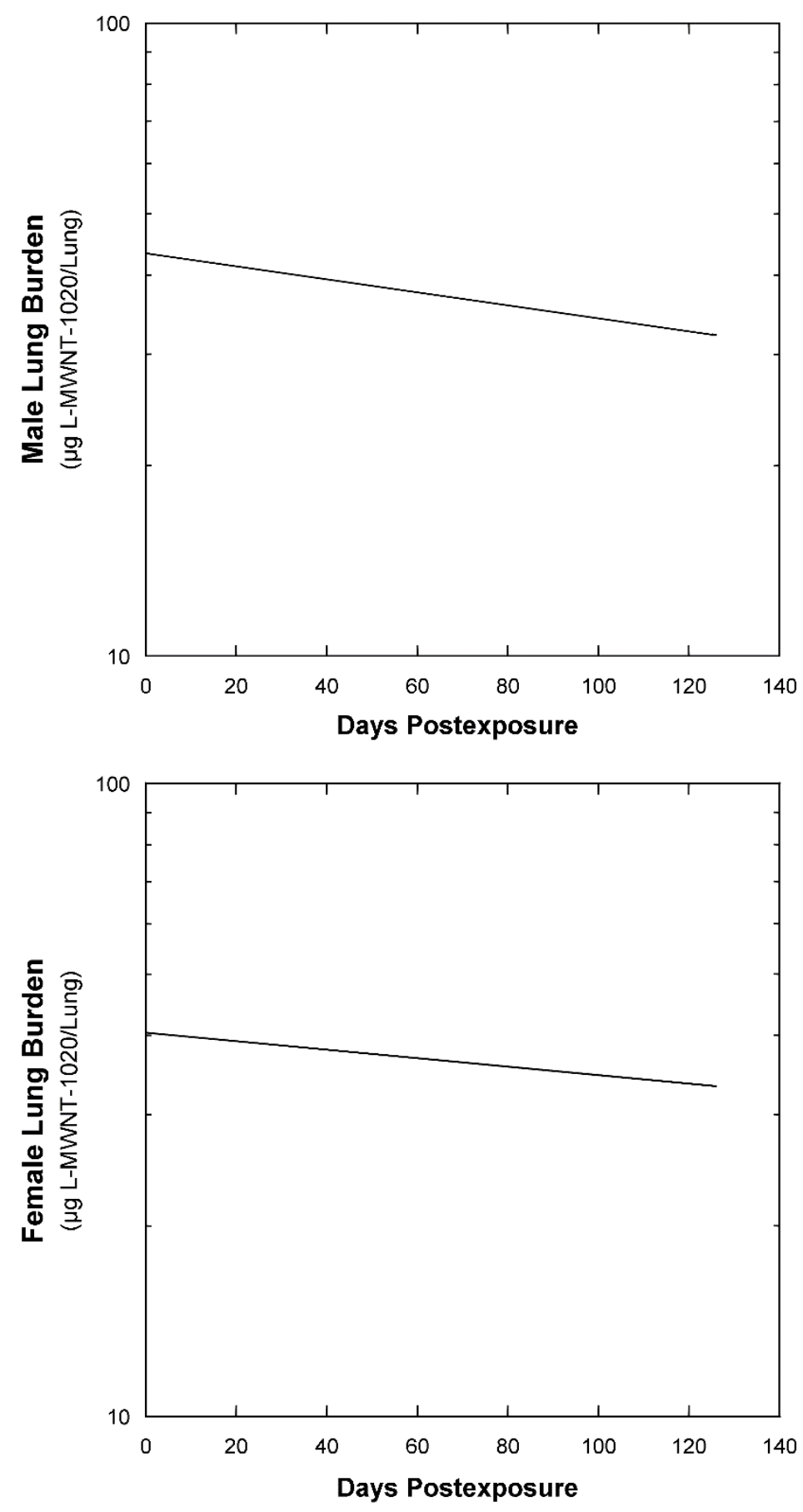

Figure C-9. Lung 1020 Long Multiwalled Carbon Nanotube Burdens in $3 \mathrm{mg} / \mathrm{m}^{3}$ Mice in the 30-day Inhalation Study of 1020 Long Multiwalled Carbon Nanotubes 

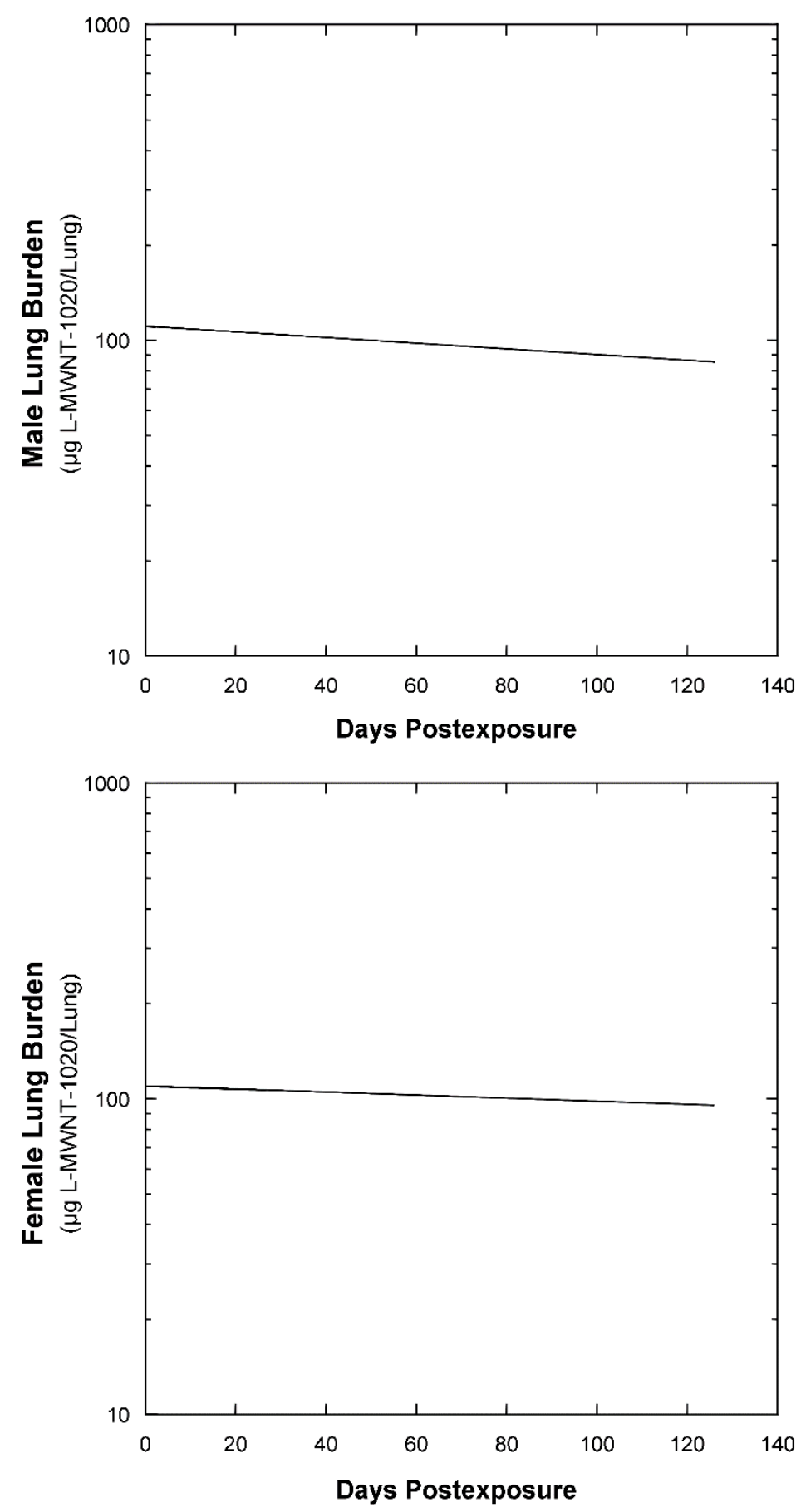

Figure C-10. Lung 1020 Long Multiwalled Carbon Nanotube Burdens in $10 \mathrm{mg} / \mathrm{m}^{3}$ Mice in the 30-day Inhalation Study of 1020 Long Multiwalled Carbon Nanotubes 


\section{Appendix D. Chemical Characterization and Generation of Chamber Concentrations}

\section{Table of Contents}

D.1. Procurement and Characterization of 1020 Long Multiwalled Carbon Nanotubes ........... D-2

D.2. Aerosol Generation and Exposure System.......................................................... D-3

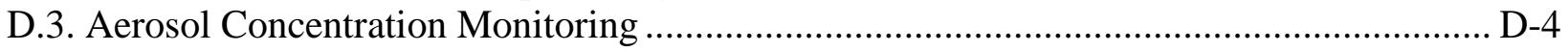

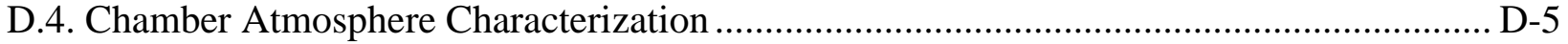

\section{Tables}

Table D-1. Summary of Chamber Concentrations in the 30-day Inhalation Studies of 1020 Long Multiwalled Carbon Nanotubes

Table D-2. Summary of Aerosol Size Measurements for Rat and Mouse Exposure Chambers in the 30-day Inhalation Studies of 1020 Long Multiwalled Carbon Nanotubes

Table D-3. Summary of Aerosol Count Median Diameters and Particle Number Concentrations for Rat and Mouse Exposure Chambers in the 30-day Inhalation Studies of 1020 Long Multiwalled Carbon Nanotubes

\section{Figures}

Figure D-1. Raman Spectra of Graphitic Materials in the 30-day Inhalation Studies of 1020 Long Multiwalled Carbon Nanotubes

Figure D-2. Schematic of the Aerosol Generation and Delivery System in the 30-day Inhalation Studies of 1020 Long Multiwalled Carbon Nanotubes. 


\section{D.1. Procurement and Characterization of 1020 Long Multiwalled Carbon Nanotubes}

The test material-1020 Long Multiwalled Carbon Nanotube (L-MWNT-1020) nominal 10 $20 \mathrm{~nm}$ outer diameter, $1030 \mu \mathrm{m}$ long multiwalled carbon nanotube (MWCNT) — was obtained from Sun Innovations, Inc. (Fremont, CA) in one lot (supplier item SN9847, supplier lot $10031301 \mathrm{M}$ ) and was used in the 30-day studies. The study laboratory, Battelle Toxicology Northwest (Richland, WA), assigned the numbers 1 through 12 to the 12 amber glass containers received from the supplier. Identity and purity analyses were conducted by various analytical chemistry laboratories and by the study laboratory. Reports on analyses performed in support of the L-MWNT-1020 studies are on file at the National Institute of Environmental Health Sciences (NIEHS).

Lot $10031301 \mathrm{M}$ of the chemical, a dull black powder, was characterized by Environmental Molecular Sciences Laboratory (EMSL) at Pacific Northwest National Laboratory (PNNL) (Richland, WA) using transmission electron microscopy (TEM), scanning electron microscopy (SEM), Raman spectroscopy, energy dispersive X-ray spectroscopy (EDS), and X-ray photoelectron spectroscopy (XPS). In addition, lot 10031301M was characterized by Elemental Analysis, Inc. (Lexington, KY), using neutron activation analysis (NAA) and by Quantachrome Instruments (Boynton Beach, FL) using helium gas pycnometry (skeletal density), electrophoretic velocimetry (zeta potential), and Brunauer-Emmett-Teller (BET) gas adsorption analysis (surface area). All nine of these assessments were performed on bulk samples from the top, middle, and bottom of one container as received; in addition, single samples from the top of each of the other 11 containers received underwent Raman analysis.

TEM images confirmed test material identity by visualizing agglomerates of MWCNTs several micrometers in length and determined an average nanotube diameter of $15.3 \mathrm{~nm}$ (range: 6.1 to $26.7 \mathrm{~nm}$ ). SEM estimated an average nanotube length of $2.6 \mu \mathrm{m}$ (range: 0.6 to $7.4 \mu \mathrm{m}$ ). These averages (length of 2,600 $\mathrm{nm}$ and width of $15.3 \mathrm{~nm}$ ) yielded an estimated length:width aspect ratio of 170:1 for the nanotubes in lot 10031301M.

Raman spectra of lot 10031301M contained spectral features consistent with those seen in spectra for commercially procured standards of similar graphitic materials, including $\mathrm{G}, \mathrm{G}^{\prime}$, and D bands. A D' band, typical of highly oxidized samples was not observed in the test material. Raman spectra of reference materials and L-MWNT-1020 are presented in Figure D-1.

EDS spectra indicated that nickel was present in the test material; subsequent NAA quantitated nickel at $0.52 \%$ by weight. None of the other elements quantitated by NAA (chlorine, cobalt, iron, and copper) were detected above $0.01 \%$. XPS survey scans detected only carbon and oxygen on the surface of the test material. Subsequent high-resolution scans indicated the surface composition of the bulk chemical was approximately 98 atom \% carbon and 2 atom \% oxygen, consistent with literature values ${ }^{83 ; 84}$. BET gas adsorption analysis indicated an average surface area of $175 \mathrm{~m}^{2} / \mathrm{g}$ for lot $10031301 \mathrm{M}$, consistent with values provided by the supplier. Skeletal density, as determined by helium gas pycnometry, was $2.0 \mathrm{~g} / \mathrm{cm}^{3}$; this result was in good agreement with the density reported by the supplier. Measurement of the electrophoretic velocity of L-MWNT-1020 in distilled water yielded a zeta potential of $-30 \mathrm{mV}$, consistent with published values for similar nanotube materials ${ }^{85}$. 
The purity of lot 10031301M was determined by Galbraith Laboratories, Inc. (Knoxville, TN), using elemental analysis of samples from the top, middle, and bottom of one of the containers received and by Netzsch Instruments (Burlington, MA) using thermogravimetric analysis (TGA) of samples from the top, middle, and bottom of one container and one sample from each of the remaining containers received. The TGA method entailed combustion of samples of graphite, glassy carbon, and L-MWNT-1020 in a lidded crucible placed on a microbalance in a furnace. The samples were combusted in the presence of oxygen as the temperature was increased from $40^{\circ} \mathrm{C}$ to $950^{\circ} \mathrm{C}$ at $5^{\circ} \mathrm{C} /$ minute. The temporal profiles of mass changes, in conjunction with the residual mass and initial sample masses, were used to demonstrate that the TGA method was capable of discriminating between MWCNT and other forms of carbon and also to calculate the percent purity of the test material.

Elemental analysis for carbon, hydrogen, nitrogen, and sulfur indicated that lot $10031301 \mathrm{M}$ was 97\% carbon by weight and the other elements assayed were below the quantitation limits of the method used $(<0.5 \%)$. TGA estimated the average percent purity of L-MWNT-1020 as approximately $99 \%$ for all containers received. The overall purity of lot $10031301 \mathrm{M}$ was determined to be $97 \%$ or greater.

To ensure stability, the bulk test material was stored in the original 12 amber glass shipping jars at room temperature. Periodic reanalyses of the test material were performed by the study laboratory with TGA and Raman spectroscopy, and no degradation of the bulk test material was detected.

\section{D.2. Aerosol Generation and Exposure System}

A schematic diagram of the L-MWNT-1020 aerosol generation and distribution system is shown in Figure D-2. The aerosol generation system consisted of a linear feed dust metering device to meter L-MWNT-1020 from a reservoir into an air stream. Within the metering device, periodic blasts of compressed air suspended small volumes of test material in the air stream for transport to the metering device exhaust tube. A particle attrition chamber was positioned immediately downstream of the metering device exhaust tube for initial particle size reduction of the test material. From the particle attrition chamber, the aerosol was passed through a single jet disperser into the distribution line. The single jet disperser assisted in further dispersion and particle size reduction. Downstream of the disperser jet, primary dilution air (filtered, compressed, humidified air) was added to increase the volumetric flow rate in the aerosol distribution line before the aerosol was passed through a cyclone separator. The cyclone separator removed the larger particles from the distribution system. The linear feed dust metering device, single jet disperser, the primary dilution air assembly and the cyclone separator were housed within a glove box located within the exposure control suite. Secondary dilution air (filtered, compressed, humidified air) was added outside of the glove box within the exposure control suite.

Within the distribution line, aerosol was conveyed from the exposure control suite to the exposure room. In the exposure room, the distribution line split into two lines for delivery to chambers situated on both sides of the exposure room. One branch (identified as the south distribution line in Figure D-2) transported aerosol to the $0.3,1$, and $3 \mathrm{mg} / \mathrm{m}^{3}$ chambers, and the second branch (identified as the north distribution line in Figure D-2) transported aerosol to the 
0.1 and $10 \mathrm{mg} / \mathrm{m}^{3}$ chambers. During exposures, the air flow through the distribution lines was controlled using house vacuum regulated by a filter-protected flow meter. A second distribution line flow control system was available during off-exposure periods. This system consisted of a vacuum transducer pump (Air-Vac Engineering Co., Inc., Seymour, CT) of higher flow capacity positioned in parallel with the flow meter control assembly that became operational only during critical shut-down periods. High-efficiency particulate air (HEPA) filters were placed before the vacuum supply and transducer pump at the end of each delivery line to remove aerosol from the airstream prior to exhausting from the room. At each exposure chamber location, aerosol was directed from the distribution line by a sampling tube into the chamber conditioned air supply for mixing prior to delivery to the chamber. The flow through the sampling tube was induced by a stainless steel ejector pump designed and fabricated at Battelle. The flow rate and configuration of each ejector pump and sampling tube combination were chosen to optimize the efficiency of the delivery system and achieve the desired exposure concentration.

The study laboratory designed the inhalation exposure chamber (Lab Products, Inc., Seaford, DE) so that uniform aerosol concentrations could be maintained throughout the chamber with the catch pans in place. The total active mixing volume of each chamber was $1.7 \mathrm{~m}^{3}$. At each exposure concentration, the chambers housed both rats and mice from the concurrent studies.

\section{D.3. Aerosol Concentration Monitoring}

Summaries of the chamber aerosol concentrations are given in Table D-1. The concentrations of L-MWNT-1020 in the exposure chambers and room air were monitored using three real-time aerosol monitors (RAMs; RAM-1, MIE, Inc., Bedford, MA, or MicroDust pro, Casella CEL, Ltd., Kempson, Bedford, England). The monitors were connected to the chambers through sample lines and a multiplexing valve designed to minimize aerosol losses caused by settling or impaction. Each RAM was multiplexed to the exposure chambers and/or the $0 \mathrm{mg} / \mathrm{m}^{3}$ chamber or the exposure room and a HEPA-filtered air blank. The output voltage of each RAM was recorded by the Battelle Exposure Data Acquisition and Control (BEDAC) software system and converted to $\mathrm{mg} / \mathrm{m}^{3}$ exposure concentration by the application of a calibration curve. Each measured concentration was compared to limit values for the locations monitored by each RAM and, if a measured concentration exceeded its control limits, the BEDAC system triggered an audible alert or, in extreme cases, terminated the exposure.

Each RAM was calibrated by constructing a response curve using the measured RAM voltages (corrected for zero offset voltage measured in a HEPA-filtered airstream) and L-MWNT-1020 concentrations determined by gravimetric analysis of filter samples obtained from the exposure chambers. Duplicate exposure chamber atmosphere samples were collected each day on $25 \mathrm{~mm}$ Pallflex ${ }^{\circledR}$ Emfab $^{\text {TM }}$ TX40H120WW Teflon ${ }^{\circledR}$-coated, glass fiber filters (Pall Corporation, East Hills, NY). Validation studies demonstrated that gravimetric and chemical-specific measurements of chamber concentrations were comparable. An ultraviolet visible spectrophotometric assay was used for chemical-specific analysis of L-MWNT-1020. This assay used an off-line Agilent 1100/1200 liquid chromatograph (Agilent, Santa Clara, CA) to measure changes in absorbance (at $538 \mathrm{~nm}$ ) of an aqueous solution that contained a dye (Procion ${ }^{\circledR}$ Red MX-5B; Sigma-Aldrich, St. Louis, MO) that had an affinity for filter-trapped L-MWNT-1020. 
The off-line chromatograph was calibrated using gravimetrically prepared calibration standards of the test article. These methods were demonstrated by the study laboratory to have adequate precision, accuracy, linear working range, day-to-day respectability, and detection limits for the L-MWNT-1020 concentrations in the exposure chambers.

\section{D.4. Chamber Atmosphere Characterization}

Aerosol particle size distribution was determined once prior to and once during the 30-day studies by collecting aerosol samples from each exposure chamber using a Mercer-style cascade impactor. L-MWNT-1020 was collected (for stages one through seven) on $37 \mathrm{~mm}$ stainless steel slides lightly coated with silicone (Mercer Impactor $37 \mathrm{~mm}$ collection discs, In-Tox Products, LLC, Moriarty, NM) or (for stage eight) $47 \mathrm{~mm}$ Teflon-coated glass fiber filters (Pallflex ${ }^{\circledR}$ Emfab $^{\mathrm{TM}}$ TX40H120WW, Pall Corporation) to establish the mass median aerodynamic diameter (MMAD) of the aerosol particles. The impactor samples were analyzed gravimetrically to determine the amount of L-MWNT-1020 collected on each stage. The relative mass of LMWNT-1020 collected on each impactor stage was analyzed by the NEWCAS impactor analysis program developed at the study laboratory based on probit analysis ${ }^{86}$. The resulting particle size distributions for chamber atmosphere samples collected during the studies are summarized in Table D-2; MMAD values were below the $3.0 \mu \mathrm{m}$ upper limit criterion required by the design of the studies.

For each exposure chamber, the count median diameter (CMD) for the aerosol and the number of particles per unit volume were determined once before and once during the 30-day studies using an electrical low pressure impactor (ELPI; Dekati Ltd., Kongsala, Finland). The ELPI counted the number of particles in 12 size bins within a size range of 0.03 to $10 \mu \mathrm{m}$. The CMD and particle number concentration were analyzed using the ELPI VI 4.0 Data Analysis Software provided by the manufacturer. The results for chamber atmosphere sample collected during the studies are summarized in Table D-3; CMDs for the aerosol ranged from 92 to $99 \mathrm{~nm}$ with the number of particles varying from $3.5 \times 10^{4}$ to $1.1 \times 10^{6}$ particles $/ \mathrm{cm}^{3}$.

Buildup and decay rates for chamber aerosol concentrations were determined at two ports for each chamber with and without animals present in the chambers. At a chamber airflow rate of $15 \mathrm{ft}^{3} /$ minute, the theoretical value for the time to achieve $90 \%$ of the target concentration after the beginning of aerosol generation ( $\left.\mathrm{T}_{90}\right)$ was approximately 9.2 minutes and the time for the chamber concentration to decay to $10 \%$ of the target concentration after aerosol generation was terminated $\left(\mathrm{T}_{10}\right)$ was approximately 12 minutes. For rats and mice in the 30 -day studies, $\mathrm{T}_{90}$ values ranged from 7 to 12 minutes without animals present and from 8 to 15 minutes with animals; $\mathrm{T}_{10}$ values ranged from 8 to 11 minutes without animals present and from 5 to 16 minutes with animals. A T 90 value of 12 minutes was selected for the studies.

The uniformity of aerosol concentration in the inhalation exposure chambers without animals was evaluated before the studies began; in addition, concentration uniformity with animals present in the chamber was measured once during the 30-day studies. Aerosol concentrations were measured using the on-line monitor system with the stream-selection valve fixed in one position to allow continuous monitoring from a single input line. Concentrations were measured at all 12 sample ports; one in front and one in back for each of six possible animal cage unit 
positions per chamber. Chamber concentration uniformity was maintained throughout the studies.

The persistence of L-MWNT-1020 in the chambers after aerosol delivery ended was determined by monitoring the concentration overnight in the $10 \mathrm{mg} / \mathrm{m}^{3}$ chamber in the 30-day studies with and without animals present in the chamber. The concentration decreased to $1 \%$ of the target concentration within 14 minutes with animals present and within 18 minutes without animals.

Stability studies of L-MWNT-1020 in the generation and delivery system were performed before and during the studies by EMSL/PNNL (TEM, Raman spectroscopy, and XPS), Quantachrome Instruments (BET surface area), Netzsch Instruments (TGA), and the study laboratory (elemental analysis by inductively coupled plasma/atomic emission spectroscopy [ICP/AES]). On each sample collection day, a sample of the bulk test material used to fill the generator reservoir was taken prior to filling the reservoir, and a sample of the test material from the generator reservoir was collected at the end of the generation day (additional bulk chemical was added to the generator each day). All six stability characterization assessments (TEM, BET, Raman spectroscopy, XPS, TGA, and elemental analysis) were performed on these bulk chemical and generator reservoir samples. All of these assessments were also performed on aerosol samples obtained from the distribution line and the 0.1 (except for BET analysis) and $10 \mathrm{mg} / \mathrm{m}^{3}$ exposure chambers. Aerosolized samples for TEM imagery were collected using an electrostatic precipitation and by impaction onto TEM grids mounted on glass fiber filters. Aerosolized samples for BET surface area analysis were collected onto $47 \mathrm{~mm}$ glass fiber filters (Performance Systematix, Inc., Grand Rapids, MI), those for Raman spectral analysis and XPS were collected onto $25 \mathrm{~mm}$ silver membrane filters (Sterlitech Corp., Kent, WA), and those for TGA and elemental analysis were collected onto $25 \mathrm{~mm}$ glass fiber (Pallflex Tissuquartz) or GH Polypro filters (Pall Corporation). BET analysis included assessments of a reference standard and TGA analysis included additional filter sample taken from the $0 \mathrm{mg} / \mathrm{m}^{3}$ chamber.

TEM imagery indicated that the morphology of the test material collected from the exposure aerosol was qualitatively similar to that observed in the bulk material. BET surface area analysis determined that the surface area of the test material in the exposure system was generally comparable to the results of the initial characterization tests of lot 10031301M. Raman spectra of L-MWNT-1020 collected from the exposure system were consistent with Raman spectra of the bulk chemical as determined in the initial test chemical characterization. XPS surface scans of the exposure system aerosol samples indicated that the surface of L-MWNT-1020 included carbon and oxygen. Overall, the oxygen surface atom percentage was less than 5\%, indicating that substantial oxidation of the test chemical did not occur during generation of aerosolized exposure atmospheres. No impurities or degradation products were detected by TGA in any of the exposure atmosphere aerosol samples; analyses conducted on samples collected before and after the 30-day studies indicated a purity greater than or equal to $98 \%$, consistent with the approximate $99 \%$ purity estimate derived by TGA analysis of the bulk chemical during the initial purity measurements of lot 10031301M. ICP/AES determination of the levels of 18 elements in microwave-assisted digests of the samples collected from the exposure system indicated all elements measured in the samples were less than their low standards except nickel, sulfur, and iron (during the 30-day studies only). These results were consistent with elemental analyses of the bulk test material in the initial characterization of the test chemical. 
Taken together, these results demonstrated that the exposure atmosphere and generator reservoir samples were in good agreement with the bulk test article, the composition of L-MWNT-1020 was stable in the exposure system, and contamination from metal materials in the exposure system did not occur.

Table D-1. Summary of Chamber Concentrations in the 30-day Inhalation Studies of 1020 Long Multiwalled Carbon Nanotubes

\begin{tabular}{lccc}
\hline & $\begin{array}{c}\text { Total Concentration } \\
\left(\mathbf{m g} / \mathbf{m}^{\mathbf{3}}\right)\end{array}$ & $\begin{array}{c}\text { Total Number of } \\
\text { Readings }\end{array}$ & $\begin{array}{c}\text { Average Concentration } \\
\left(\mathbf{m g} / \mathbf{m}^{\mathbf{3}}\right)\end{array}$ \\
\hline Rat Chambers & & 179 & \\
& 0.1 & 179 & $0.10 \pm 0.01$ \\
& 0.3 & 192 & $0.30 \pm 0.01$ \\
1 & 180 & $0.98 \pm 0.05$ \\
Mouse Chambers & 17 & & $2.96 \pm 0.18$ \\
& 10 & 177 & $10.01 \pm 0.40$ \\
& 0.1 & 177 & $0.10 \pm 0.01$ \\
& 0.3 & 186 & $0.30 \pm 0.02$ \\
1 & 180 & $0.99 \pm 0.05$ \\
& 3 & 177 & $2.95 \pm 0.17$ \\
\hline
\end{tabular}

${ }^{\mathrm{a}}$ Mean \pm standard deviation.

Table D-2. Summary of Aerosol Size Measurements for Rat and Mouse Exposure Chambers in the 30-day Inhalation Studies of 1020 Long Multiwalled Carbon Nanotubes

Target Concentration $\left(\mathbf{m g} / \mathrm{m}^{3}\right)$

\begin{tabular}{ccc}
\hline 0.1 & 1.7 & 2.6 \\
0.3 & 2.3 & 2.5 \\
1 & 2.8 & 2.1 \\
3 & 2.0 & 2.6 \\
10 & 2.2 & 2.2 \\
\hline
\end{tabular}

Mass Median Aerodynamic Diameter $(\mu \mathrm{m})$

Geometric Standard Deviation

Table D-3. Summary of Aerosol Count Median Diameters and Particle Number Concentrations for Rat and Mouse Exposure Chambers in the 30-day Inhalation Studies of 1020 Long Multiwalled Carbon Nanotubes

\begin{tabular}{ccc}
\hline Target Concentration $\left(\mathbf{m g} / \mathbf{m}^{\mathbf{3}}\right)$ & Count Median Diameter $(\boldsymbol{\mu m})$ & Number of Particles/cm $^{\mathbf{3}}$ \\
\hline 0.1 & 96 & $3.5 \times 10^{4}$ \\
0.3 & 95 & $7.8 \times 10^{4}$ \\
1 & 92 & $2.5 \times 10^{5}$ \\
3 & 94 & $4.9 \times 10^{5}$ \\
10 & 99 & $1.1 \times 10^{6}$ \\
\hline
\end{tabular}



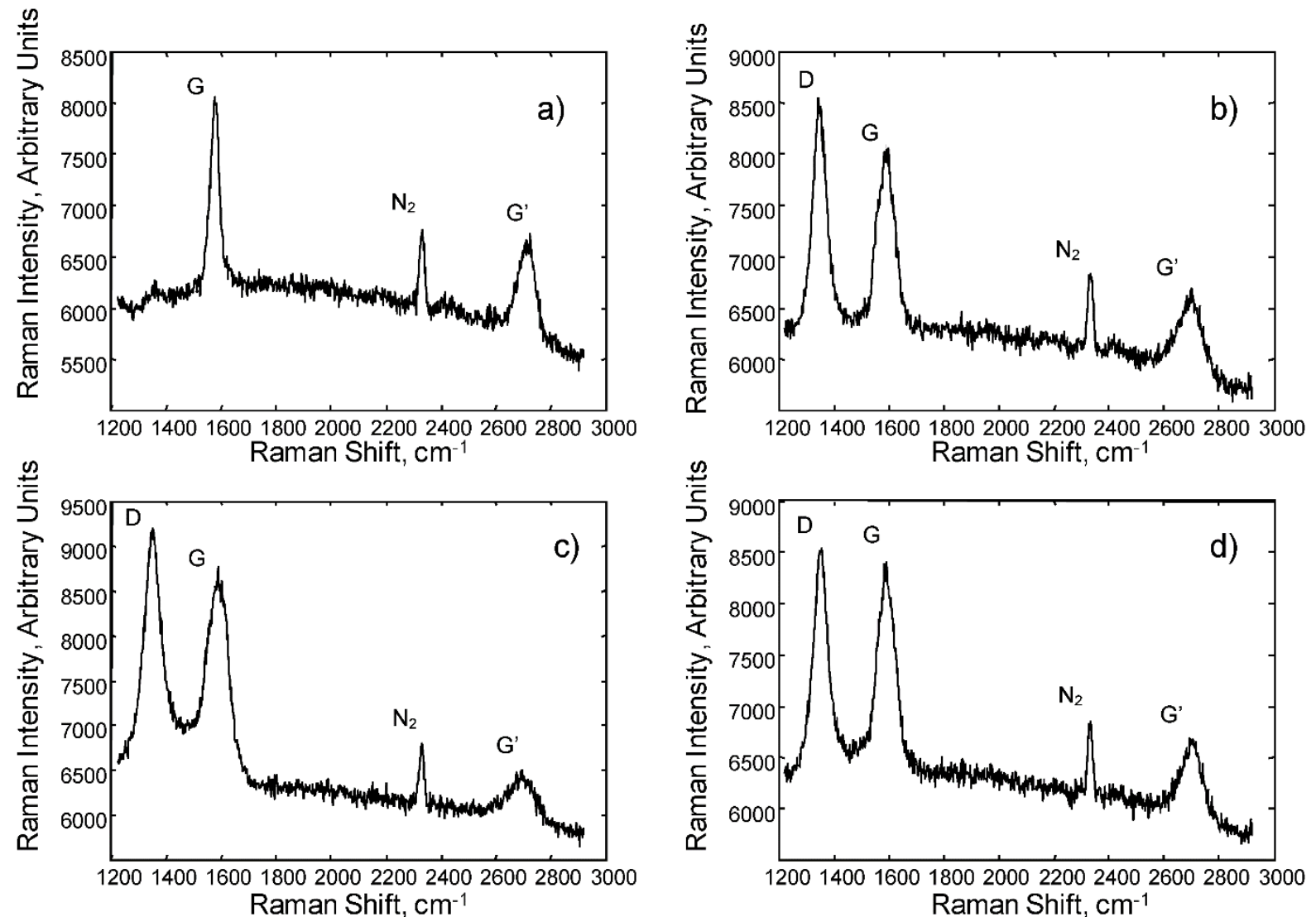

Figure D-1. Raman Spectra of Graphitic Materials in the 30-day Inhalation Studies of 1020 Long Multiwalled Carbon Nanotubes

A) Graphite, B) glassy carbon, C) commercially procured MWCNT standard, D) test material (lot 10031301M). 

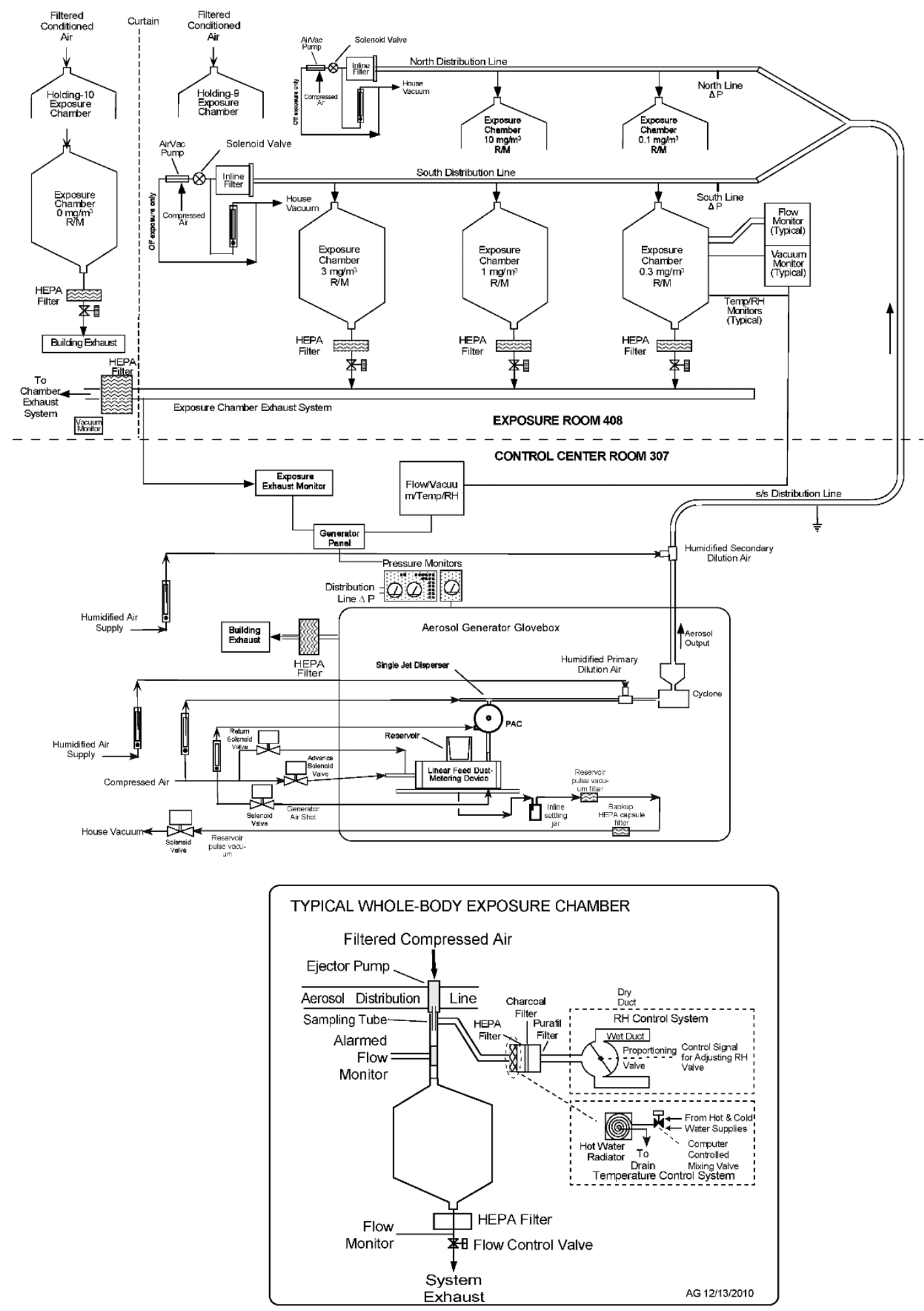

Figure D-2. Schematic of the Aerosol Generation and Delivery System in the 30-day Inhalation Studies of 1020 Long Multiwalled Carbon Nanotubes 


\section{Appendix E. Ingredients, Nutrient Composition, and Contaminant Levels in NTP-2000 Rat and Mouse Ration}

\section{Tables}

Table E-1. Ingredients of NTP-2000 Rat and Mouse Ration.

E-2

Table E-2. Vitamins and Minerals in NTP-2000 Rat and Mouse Ration ${ }^{\mathrm{a}}$

Table E-3. Nutrient Composition of NTP-2000 Rat and Mouse Ration

Table E-4. Contaminant Levels in NTP-2000 Rat and Mouse Ration ${ }^{a}$ 
Table E-1. Ingredients of NTP-2000 Rat and Mouse Ration

\begin{tabular}{lc}
\hline \multicolumn{1}{c}{ Ingredients } & Percent by Weight \\
\hline Ground Hard Winter Wheat & 22.26 \\
Ground \#2 Yellow Shelled Corn & 22.18 \\
Wheat Middlings & 15.0 \\
Oat Hulls & 8.5 \\
Alfalfa Meal (Dehydrated, 17\% Protein) & 7.5 \\
Purified Cellulose & 5.5 \\
Soybean Meal (49\% Protein) & 5.0 \\
Fish Meal (60\% Protein) & 4.0 \\
Corn Oil (without Preservatives) & 3.0 \\
Soy Oil (without Preservatives) & 3.0 \\
Dried Brewer's Yeast & 1.0 \\
Calcium Carbonate (USP) & 0.9 \\
Vitamin Premix & 0.5 \\
Mineral Premix & 0.5 \\
Calcium Phosphate, Dibasic (USP) & 0.4 \\
Sodium Chloride & 0.3 \\
Choline Chloride (70\% Choline) & 0.26 \\
Methionine & 0.2 \\
\hline USP Uned Stes Plat &
\end{tabular}

USP = United States Pharmacopeia.

${ }^{a}$ Wheat middlings as carrier.

${ }^{\mathrm{b}}$ Calcium carbonate as carrier.

Table E-2. Vitamins and Minerals in NTP-2000 Rat and Mouse Ration ${ }^{\mathrm{a}}$

\begin{tabular}{lcl}
\hline & Amount & \multicolumn{1}{c}{ Source } \\
\hline Vitamins & & \\
$\mathrm{A}$ & $4,000 \mathrm{IU}$ & Stabilized vitamin A palmitate or acetate \\
$\mathrm{D}$ & $1,000 \mathrm{IU}$ & D-activated animal sterol \\
$\mathrm{K}$ & $1.0 \mathrm{mg}$ & Menadione sodium bisulfite complex \\
$\alpha$-Tocopheryl Acetate & $100 \mathrm{IU}$ & - \\
Niacin & $23 \mathrm{mg}$ & - \\
Folic Acid & $1.1 \mathrm{mg}$ & - \\
$d$-Pantothenic Acid & $10 \mathrm{mg}$ & $d$-Calcium pantothenate \\
Riboflavin & $3.3 \mathrm{mg}$ & - \\
Thiamine & $4 \mathrm{mg}$ & Thiamine mononitrate \\
B 12 & $52 \mu \mathrm{g}$ & - \\
Pyridoxine & $6.3 \mathrm{mg}$ & Pyridoxine hydrochloride \\
Biotin & $0.2 \mathrm{mg}$ & $d$-Biotin \\
\hline
\end{tabular}




\begin{tabular}{lcl}
\hline & Amount & \multicolumn{1}{c}{ Source } \\
\hline Minerals & & \\
Magnesium & $514 \mathrm{mg}$ & Magnesium oxide \\
Iron & $35 \mathrm{mg}$ & Iron sulfate \\
Zinc & $12 \mathrm{mg}$ & Zinc oxide \\
Manganese & $10 \mathrm{mg}$ & Manganese oxide \\
Copper & $2.0 \mathrm{mg}$ & Copper sulfate \\
Iodine & $0.2 \mathrm{mg}$ & Calcium iodate \\
Chromium & $0.2 \mathrm{mg}$ & Chromium acetate \\
\hline
\end{tabular}

${ }^{\mathrm{a}}$ Per kg of finished product.

Table E-3. Nutrient Composition of NTP-2000 Rat and Mouse Ration

\begin{tabular}{|c|c|c|c|}
\hline Nutrient & $\begin{array}{c}\text { Mean } \pm \text { Standard } \\
\text { Deviation }\end{array}$ & Range & Number of Samples \\
\hline Protein (\% by Weight) & $14.7 \pm 0.34$ & $14.4-15.3$ & 7 \\
\hline Crude fat ( $\%$ by Weight) & $8.6 \pm 0.40$ & $8.0-9.0$ & 7 \\
\hline Crude fiber ( $\%$ by Weight) & $9.2 \pm 0.59$ & $8.4-9.8$ & 7 \\
\hline Ash (\% by Weight) & $4.9 \pm 0.13$ & $4.7-5.1$ & 7 \\
\hline \multicolumn{4}{|c|}{ Amino Acids (\% of Total Diet) } \\
\hline Arginine & $0.794 \pm 0.070$ & $0.67-0.97$ & 26 \\
\hline Cystine & $0.220 \pm 0.022$ & $0.15-0.25$ & 26 \\
\hline Glycine & $0.700 \pm 0.038$ & $0.62-0.80$ & 26 \\
\hline Histidine & $0.344 \pm 0.074$ & $0.27-0.68$ & 26 \\
\hline Isoleucine & $0.546 \pm 0.041$ & $0.43-0.66$ & 26 \\
\hline Leucine & $1.092 \pm 0.063$ & $0.96-1.24$ & 26 \\
\hline Lysine & $0.700 \pm 0.110$ & $0.31-0.86$ & 26 \\
\hline Methionine & $0.408 \pm 0.043$ & $0.26-0.49$ & 26 \\
\hline Phenylalanine & $0.621 \pm 0.048$ & $0.47-0.72$ & 26 \\
\hline Threonine & $0.508 \pm 0.040$ & $0.43-0.61$ & 26 \\
\hline Tryptophan & $0.153 \pm 0.027$ & $0.11-0.20$ & 26 \\
\hline Tyrosine & $0.413 \pm 0.063$ & $0.28-0.54$ & 26 \\
\hline Valine & $0.663 \pm 0.040$ & $0.55-0.73$ & 26 \\
\hline \multicolumn{4}{|c|}{ Essential Fatty Acids (\% of Total Diet) } \\
\hline Linoleic & $3.92 \pm 0.307$ & $2.99-4.55$ & 26 \\
\hline Linolenic & $0.31 \pm 0.030$ & $0.21-0.35$ & 26 \\
\hline \multicolumn{4}{|l|}{ Vitamins } \\
\hline Vitamin A (IU/kg) & $3,989 \pm 38$ & $3,590-4,540$ & 7 \\
\hline Vitamin D (IU/kg) & $1,000^{\mathrm{a}}$ & - & - \\
\hline
\end{tabular}




\begin{tabular}{|c|c|c|c|}
\hline Nutrient & $\begin{array}{c}\text { Mean } \pm \text { Standard } \\
\text { Deviation }\end{array}$ & Range & Number of Samples \\
\hline$\alpha$-Tocopherol (ppm) & $77 \pm 24.82$ & $7.81-124.0$ & 26 \\
\hline Thiamine (ppm) $)^{\mathrm{b}}$ & $9.4 \pm 1.29$ & $7.2-10.8$ & 7 \\
\hline Riboflavin (ppm) & $8.1 \pm 2.91$ & $4.20-17.50$ & 26 \\
\hline Niacin (ppm) & $78.9 \pm 8.52$ & $66.4-98.2$ & 26 \\
\hline Pantothenic Acid (ppm) & $26.7 \pm 11.63$ & $17.4-81.0$ & 26 \\
\hline Pyridoxine $(\mathrm{ppm})^{\mathrm{b}}$ & $9.7 \pm 2.09$ & $6.44-14.3$ & 26 \\
\hline Folic Acid (ppm) & $1.59 \pm 0.45$ & $1.15-3.27$ & 26 \\
\hline Biotin (ppm) & $0.32 \pm 0.10$ & $0.20-0.704$ & 26 \\
\hline Vitamin $B_{12}(p p b)$ & $54.9 \pm 37.2$ & $18.3-174.0$ & 26 \\
\hline Choline (ppm) ${ }^{\mathrm{b}}$ & $2,665 \pm 631$ & $1,160-3,790$ & 26 \\
\hline \multicolumn{4}{|l|}{ Minerals } \\
\hline Calcium (\%) & $0.894 \pm 0.044$ & $0.814-0.937$ & 7 \\
\hline Phosphorus (\%) & $0.570 \pm 0.018$ & $0.548-0.594$ & 7 \\
\hline Potassium (\%) & $0.669 \pm 0.030$ & $0.626-0.733$ & 26 \\
\hline Chloride (\%) & $0.386 \pm 0.037$ & $0.300-0.474$ & 26 \\
\hline Sodium (\%) & $0.193 \pm 0.024$ & $0.160-0.283$ & 26 \\
\hline Magnesium (\%) & $0.216 \pm 0.057$ & $0.185-0.490$ & 26 \\
\hline Sulfur (\%) & $0.170 \pm 0.029$ & $0.116-0.209$ & 14 \\
\hline Iron (ppm) & $190.5 \pm 38.0$ & $135-311$ & 26 \\
\hline Manganese (ppm) & $50.7 \pm 9.72$ & $21.0-73.1$ & 26 \\
\hline Zinc (ppm) & $58.2 \pm 26.89$ & $43.3-184.0$ & 26 \\
\hline Copper (ppm) & $7.44 \pm 2.60$ & $3.21-16.3$ & 26 \\
\hline Iodine (ppm) & $0.514 \pm 0.195$ & $0.158-0.972$ & 26 \\
\hline Chromium (ppm) & $0.674 \pm 0.265$ & $0.330-1.380$ & 26 \\
\hline Cobalt (ppm) & $0.235 \pm 0.157$ & $0.094-0.864$ & 26 \\
\hline
\end{tabular}

${ }^{\mathrm{a} F r o m}$ formulation.

${ }^{\mathrm{b}}$ As hydrochloride (thiamine and pyridoxine) or chloride (choline). 
Table E-4. Contaminant Levels in NTP-2000 Rat and Mouse Ration ${ }^{a}$

\begin{tabular}{|c|c|c|c|}
\hline & $\begin{array}{l}\text { Mean } \pm \text { Standard } \\
\text { Deviation }^{\mathrm{b}}\end{array}$ & Range & Number of Samples \\
\hline \multicolumn{4}{|l|}{ Contaminants } \\
\hline Arsenic (ppm) & $0.20 \pm 0.019$ & $0.17-0.23$ & 7 \\
\hline Cadmium (ppm) & $0.05 \pm 0.004$ & $0.05-0.06$ & 7 \\
\hline Lead (ppm) & $0.11 \pm 0.082$ & $0.07-0.29$ & 7 \\
\hline Mercury (ppm) & $<0.02$ & - & - \\
\hline Selenium (ppm) & $0.16 \pm 0.030$ & $0.14-0.23$ & 7 \\
\hline Aflatoxins (ppb) & $<5.00$ & - & 7 \\
\hline Nitrate Nitrogen $(\mathrm{ppm})^{\mathrm{c}}$ & $13.11 \pm 3.54$ & $10.0-18.1$ & - \\
\hline Nitrite Nitrogen $(\mathrm{ppm})^{\mathrm{c}}$ & 0.61 & - & 7 \\
\hline BHA $(\mathrm{ppm})^{\mathrm{d}}$ & $<1.0$ & - & 7 \\
\hline BHT $(\mathrm{ppm})^{\mathrm{d}}$ & $<1.0$ & - & 7 \\
\hline Aerobic Plate Count (CFU/g) & $<10.0$ & - & 7 \\
\hline Coliform (MPN/g) & $3.0 \pm 0$ & 3.0 & 7 \\
\hline Escherichia coli (MPN/g) & $<10$ & - & 7 \\
\hline Salmonella (MPN/g) & Negative & - & 7 \\
\hline Total Nitrosoamines $(\mathrm{ppb})^{\mathrm{e}}$ & $7.7 \pm 3.57$ & $3.6-11.8$ & 7 \\
\hline$N$-Nitrosodimethylamine (ppb) ${ }^{\mathrm{e}}$ & $3.6 \pm 2.39$ & $1.0-7.4$ & 7 \\
\hline$N$-Nitrosopyrrolidine $(\mathrm{ppb})^{\mathrm{e}}$ & $4.1 \pm 1.83$ & $2.4-7.5$ & 7 \\
\hline \multicolumn{4}{|l|}{ Pesticides (ppm) } \\
\hline$\alpha-\mathrm{BHC}$ & $<0.01$ & - & 7 \\
\hline$\beta-\mathrm{BHC}$ & $<0.02$ & - & 7 \\
\hline$\gamma$-BHC & $<0.01$ & - & 7 \\
\hline$\delta$-BHC & $<0.01$ & - & 7 \\
\hline Heptachlor & $<0.01$ & - & 7 \\
\hline Aldrin & $<0.01$ & - & 7 \\
\hline Heptachlor Epoxide & $<0.01$ & - & 7 \\
\hline DDE & $<0.01$ & - & 7 \\
\hline DDD & $<0.01$ & - & 7 \\
\hline DDT & $<0.01$ & - & 7 \\
\hline $\mathrm{HCB}$ & $<0.01$ & - & 7 \\
\hline Mirex & $<0.01$ & - & 7 \\
\hline Methoxychlor & $<0.05$ & - & 7 \\
\hline Dieldrin & $<0.01$ & - & 7 \\
\hline Endrin & $<0.01$ & - & 7 \\
\hline
\end{tabular}


L-MWNT-1020, NTP TOX 94

\begin{tabular}{lccc}
\hline & $\begin{array}{c}\text { Mean } \pm \text { Standard } \\
\text { Deviation }\end{array}$ & Range & Number of Samples \\
\hline Telodrin & $<0.01$ & - & 7 \\
Chlordane & $<0.05$ & - & 7 \\
Toxaphene & $<0.10$ & - & 7 \\
Estimated PCBs & $<0.20$ & - & 7 \\
Ronnel & $<0.01$ & - & 7 \\
Ethion & $<0.02$ & - & 7 \\
Trithion & $<0.05$ & - & 7 \\
Diazinon & $<0.10$ & - & 7 \\
Methyl Chlorpyrifos & $0.14 \pm 0.077$ & $-0.038-0.223$ & 7 \\
Methyl Parathion & $<0.02$ & - & 7 \\
Ethyl Parathion & $<0.02$ & $-0.020-0.299$ & 7 \\
Malathion & $0.11 \pm 0.096$ & - & 7 \\
Endosulfan I & $<0.01$ & - & 7 \\
Endosulfan II & $<0.01$ & - & 7 \\
Endosulfan Sulfate & $<0.03$ & & 7 \\
\hline
\end{tabular}

$\mathrm{CFU}=$ colony-forming units; $\mathrm{MPN}=$ most probable number; $\mathrm{BHC}=$ hexachlorocyclohexane or benzene hexachloride;

$\mathrm{PCB}=$ polychlorinated biphenyl.

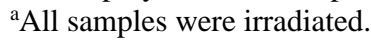

${ }^{b}$ For values less than the limit of detection, the detection limit is given as the mean.

'Sources of contamination: alfalfa, grains, and fish meal.

${ }^{\mathrm{d}}$ Sources of contamination: soy oil and fish meal.

${ }^{\mathrm{e}} \mathrm{All}$ values were corrected for percent recovery. 


\section{Appendix F. Sentinel Animal Program \\ Table of Contents}

F.1. Methods

F.2. Results.

Tables

Table F-1. Laboratory Methods and Agents Tested for in the Sentinel Animal Program F-2 


\section{F.1. Methods}

Rodents used in the National Toxicology Program are produced in optimally clean facilities to eliminate potential pathogens that may affect study results. The Sentinel Animal Program is part of the periodic monitoring of animal health that occurs during the toxicologic evaluation of test compounds. Under this program, the disease state of the rodents is monitored via sera or feces from extra (sentinel) or dosed animals in the study rooms. The sentinel animals and the study animals are subject to identical environmental conditions. Furthermore, the sentinel animals come from the same production source and weanling groups as the animals used for the studies of test compounds.

In these studies on multiwalled carbon nanotubes, all samples were processed appropriately with serology performed by IDEXX Bioanalytics (formerly Research Animal Diagnostic Laboratory [RADIL], University of Missouri), Columbia, MO, for determination of the presence of pathogens. The laboratory methods and agents for which testing was performed are tabulated below; the times at which samples were collected during the studies are also listed.

Blood was collected from five animals per sex per timepoint.

Table F-1. Laboratory Methods and Agents Tested for in the Sentinel Animal Program

\begin{tabular}{|c|c|}
\hline Method and Test & Time of Collection \\
\hline \multicolumn{2}{|l|}{ Rats } \\
\hline \multicolumn{2}{|l|}{ Multiplex Fluorescent Immunoassay } \\
\hline Kilham Rat Virus & 3 weeks and study termination \\
\hline Mycoplasma pulmonis & 3 weeks and study termination \\
\hline Parvo NS-1 & 3 weeks and study termination \\
\hline Pneumonia Virus of Mice & 3 weeks and study termination \\
\hline Rat Coronavirus/Sialodacryoadenitis Virus & 3 weeks and study termination \\
\hline Rat Minute Virus & 3 weeks and study termination \\
\hline Rat Parvovirus & 3 weeks and study termination \\
\hline Rat Theilovirus (RTV) & 3 weeks and study termination \\
\hline Sendai & 3 weeks and study termination \\
\hline Theiler's Murine Encephalomyelitis Virus & 3 weeks and study termination \\
\hline Toolan's H-1 & 3 weeks and study termination \\
\hline \multicolumn{2}{|l|}{ Mice } \\
\hline \multicolumn{2}{|l|}{ Multiplex Fluorescent Immunoassay } \\
\hline Ectromelia Virus & 3 weeks and study termination \\
\hline Epizootic Diarrhea of Infant Mice & 3 weeks and study termination \\
\hline Lymphocytic Choriomeningitis Virus & 3 weeks and study termination \\
\hline M. pulmonis & 3 weeks and study termination \\
\hline Mouse Hepatitis Virus & 3 weeks and study termination \\
\hline
\end{tabular}




\begin{tabular}{lc}
\hline \multicolumn{1}{c}{ Method and Test } & Time of Collection \\
\hline Mouse Norovirus & 3 weeks and study termination \\
Parvo NS-1 & 3 weeks and study termination \\
Minute Virus of Mice & 3 weeks and study termination \\
Mouse Parvovirus & 3 weeks and study termination \\
Pneumonia Virus of Mice & 3 weeks and study termination \\
Reovirus & 3 weeks and study termination \\
Sendai & 3 weeks and study termination \\
Theiler's Murine Encephalomyelitis Virus & 3 weeks and study termination \\
\hline
\end{tabular}

\section{F.2. Results}

All test results were negative. 


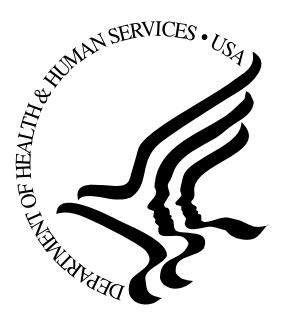

\title{
National Toxicology Program
}

\author{
NTP Central Data Management, MD EC-03
}

National Institute of Environmental Health Sciences

P.O. Box 12233

Research Triangle Park, NC 27709

http://ntp.niehs.nih.gov 